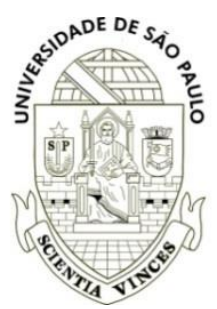

UNIVERSIDADE DE SÃO PAULO

PROGRAMA DE PÓS-GRADUAÇÃO INTERUNIDADES DE ESTÉTICA E HISTÓRIA DA ARTE

ANA PAUla CATtAi PiSMEL

Schenberg e as Bienais

São Paulo

Julho de 2018 
Ana PAUla CATTAI PISMEL

\section{Schenberg e as Bienais}

Tese apresentada ao Programa Interunidades de Pós-Graduação em Estética e História da Arte (PGHEA/USP) para obtenção do título de Doutora em Estética e História da Arte.

Orientadora: Prof. ${ }^{a}$ Dr. ${ }^{a}$ Elza Ajzenberg.

Linha de pesquisa: Teoria e Crítica de Arte.

São Paulo

Julho de 2018 


\begin{abstract}
AUTORIZO A REPRODUÇÃO E DIVULGAÇÃO TOTAL E PARCIAL DESTE TRABALHO, POR QUALQUER MEIO CONVENCIONAL OU ELETRÔNICO, PARA FINS DE ESTUDO E PESQUISA, DESDE QUE CITADA A FONTE.
\end{abstract}

\author{
Catalogação da Publicação \\ Biblioteca Lourival Gomes Machado \\ Museu de Arte Contemporânea da Universidade de São Paulo
}

Pismel, Ana Paula Cattai.

Schenberg e as Bienais / Ana Paula Cattai Pismel ; orientadora Elza Ajzenberg. -- São Paulo, 2018.

249 f. : il.

Tese (Doutorado - Programa de Pós-Graduação Interunidades em Estética e História da Arte) -- Universidade de São Paulo, 2018.

1. Crítica de Arte - Brasil - Século 20. 2. Bienais de Arte - São Paulo (SP). 3. Bienal Internacional de São Paulo. 4. Schenberg, Mario, 1914-1990. I. Ajzenberg, Elza. II. Título.

CDD 701.18 
Nome: PISMEL, Ana Paula Cattai.

Título: Schenberg e as Bienais

Dissertação apresentada ao Programa Interunidades de Pós-Graduação em Estética e História da Arte (PGHEA/USP) para obtenção do título de Mestre em

Estética e História da Arte.

Orientadora: Prof. ${ }^{\text {a }}$ Dr. ${ }^{a}$ Elza Ajzenberg.

Linha de pesquisa: Teoria e Crítica de Arte.

Aprovada em:

\section{Banca Examinadora}

Prof. Dr. Instituição:

Julgamento: Assinatura:

Prof. Dr. Instituição:

Julgamento: Assinatura:

Prof. Dr. Instituição:

Julgamento: Assinatura:

Prof. Dr. Instituição:

Julgamento: Assinatura:

Prof. Dr. Instituição:

Julgamento: Assinatura: 
À minha família e a Paulo, pelo suporte e compreensão

Aos que acreditam na arte como uma necessidade básica do ser humano ${ }^{1}$

1 "É comum ouvirmos a seguinte pergunta: qual é a importância da arte, quando faltam coisas básicas? A resposta é natural: a arte é uma necessidade básica, é o alimento da alma." Fala de Raquel Machado Fernandes, também aluna, na ocasião, da disciplina História da Arte Brasileira, ministrada no segundo semestre de 2015 pela Prof. ${ }^{a}$ Elza Ajzenberg, pelo Programa Interunidades de Pós-Graduação em Estética e História da Arte - USP. Em meio às demais participações dos colegas, essa contribuição veio ao encontro do que todos nós gostaríamos, então, de formular. 


\section{Agradecimentos}

Aos brasileiros, que por meio da CAPES possibilitaram a realização desta pesquisa.

À Universidade de São Paulo, pelo ambiente universitário amplo e repleto de possibilidades de aprendizado, o qual pude viver intensamente enquanto estudante desde a graduação.

Ao Programa Interunidades de Estética e História da Arte - USP, seu corpo docente e administrativo, pelo suporte oferecido. Dedico um agradecimento especial os analistas e técnicos acadêmicos Joana D’Arc Figueiredo, Paulo Marquezini, Águida Mantegna e Neuza Maria Falavigna Brandão.

À Prof. ${ }^{a}$ Dr. ${ }^{a}$ Elza Ajzenberg, orientadora desta tese, pela paciência e generosidade incomuns, pelos ensinamentos e pelo exemplo de seriedade e excelência acadêmica. Agradeço, sobretudo, por ter me apresentado ao pensamento de Mario Schenberg.

À Prof. ${ }^{a}$ Dr. ${ }^{a}$ Alecsandra Matias de Oliveira, que sempre esteve pronta a me ouvir, esclarecer minhas dúvidas e me aconselhar no decorrer desse percurso. Pela competência, desprendimento e incentivo, agradeço imensamente.

Ao Professor Dr. Edson leite, pela atenção e disponibilidade ímpares e pelos conselhos tão relevantes para o andamento desta pesquisa. À Prof. ${ }^{a}$ Dr. $^{a}$ Jane Marques, pelo acolhimento repleto de ensinamentos no Estágio Supervisionado do Programa de Aperfeiçoamento de Ensino. Ao Prof. Dr. Francisco Alembert e à Polyana Canhête, sou imensamente grata pela simpatia, pelo apoio e, claro, pelas preciosas pistas com relação às Bienais de São Paulo.

Aos colegas pesquisadores, agradeço pelo apoio mútuo em meio às alegrias e expectativas inerentes à pesquisa e à pós-graduação. Um aceno espacial àqueles com os quais dividi mais proximamente esta caminhada: Rosana Dalla Piazza, Rosane Busmann, Joseane Alves Ferreira, Diogo Gomes dos Santos, Delmira Nardy, Antônio Herci, Karin Magnavita de Carvalho, Sílvia Czapsky e Edson Luíz Oliveira.

Ao Centro Mario Schenberg de Documentação da Pesquisa em Artes - ECA/USP e equipe, sem os quais este trabalho não teria sido possível. Merecem agradecimento, ainda, os bolsistas Marcela Matos, Karina Borges, Marcos Salles, Beatriz dos Prazeres Rocha, Fábio Chagas da Silva, Rosana Dalla Piazza e Evelyne Amorim. 
Ao Arquivo Histórico Wanda Svevo da Fundação Bienal, em especial à pesquisadora Ana Paula Andrade Marques, pela preciosa assessoria, e às pesquisadoras Marcele Souto Yakabi, Khadyg Leite Fares Cavalheiro e Alexia Mendonça de Oliveira, pelo atendimento diário.

Ao Acervo Histórico do Instituto de Física da USP, também depositário do Arquivo Schenberg, no qual pude contar com o valioso auxílio de Walkiria Fucilli Chassot, bem como dos bolsistas Artur Correia Alegre, Barbra Miguele de Sá e Carlos Alberto Chaves.

Ao Arquivo do Instituto de Estudos Brasileiros e seus bibliotecários que, com grande atenção, auxiliaram o de levantamento de parte das fontes primárias utilizadas nesta pesquisa.

Aos entrevistados no decorrer desta pesquisa, a saber, o curador Fábio Magalhães, os artistas José Roberto Aguilar, Maria Bonomi e Caciporé Torres, o físico Sílvio Salinas e a cientista Ana Clara Guerrini Schenberg. Vocês me ajudaram a acessar aspectos aos quais, de outro modo, eu não teria acesso.

À minha família: Maria José e José Jarbas, amados pais, pelos momentos de plenitude e apoio incondicional, pela presença reconfortante e pela compreensão das ausências. À aos Adriana e Ana Cláudia, queridas irmãs, pelas conversas, conselhos e companhia. A todos vocês, minha eterna gratidão.

Àquele que, com serenidade e carinho imensos, soube comemorar pequenas conquistas e compreender grandes ansiedades. Paulo, obrigada por ser quem é e estar a meu lado no doutorado, assim como esteve no mestrado.

Aos amigos que, próximos ou distantes, fizeram parte dessa caminhada, especialmente Ana Paula Dibbern, José Hilton Nascimento Neto e Alessandra de Paula Oliveira, pela convivência diária, pelas risadas e conversas sobre amenidades que fizeram um bem enorme nos momentos de cansaço.

Não tão próximos fisicamente, mas não menos importantes, são os amigos cuja presença é sentida apesar da distância. São eles, Juliana Braz Ferire, Juliana Isquerdo, Manuela Petschilies, Nathália Fidêncio. A vocês, meus agradecimentos pela compreensão das ausências e pelo ânimo transmitido nos contatos limitados pelo espaço e tempo que se interpõem às nossas caminhadas individuais. 


\section{Título}

Schenberg e as Bienais

\section{Resumo}

Este estudo objetivou evidenciar a atuação de Mario Schenberg na organização das Bienais Internacionais de São Paulo enquanto crítico de arte, nas décadas de 1960 e 1970. Foi analisado o envolvimento do crítico na Sala Especial do pintor Alfredo Volpi na VI Bienal (1961), bem como sua participação no júri de seleção da representação brasileira na VIII, IX e X Bienais (1965, 1967 e 1969). Foi examinada, ainda, a participação de Schenberg nas Mesas Redondas promovidas pela Associação Internacional de Críticos de Arte junto às edições de 1969 e 1971 (X e XI Bienais). A investigação tomou por fontes primárias as críticas originais do Centro Mario Schenberg de Documentação da Pesquisa em Arte - ECA/USP escritas no período delimitado, bem como os demais livros, artigos e entrevistas do crítico; acrescente-se a esse material as entrevistas realizadas com artistas, curadores e cientistas que conviveram com Mario Schenberg nessas duas décadas. Além disso, foi realizado um levantamento documental no Arquivo Histórico Wanda Svevo, da Fundação Bienal. A presença do crítico no certame se deu, em primeiro lugar, por conta de sua proximidade com os artistas e seu interesse pela arte e, em segundo lugar, por sua capacidade de trazer um novo olhar para com as obras de arte, que poderia agregar a singularidade da figura de Mario Schenberg aos quadros da Bienal. Ao entender que era função do certame promover visibilidade para os novos artistas que começavam a desenvolver seu trabalho e a definir novos caminhos para a arte, o crítico assumiu o papel de facilitador da aceitação de novos artistas e tendências na representação brasileira das Bienais.

Palavras-chave: Mario Schenberg, Bienal Internacional de São Paulo, crítica de arte, décadas de 1960 e 1970. 


\title{
Title
}

Schenberg and the Biennials

\begin{abstract}
This study had the objective of highlighting Mario Schenberg's action in the Sao Paulo's International Biennial organization while art critic, in the decades of 1960 and 1970. It was analysed the critic's involvement in the painter Alfredo Volpi's Special Room in the VI Biennial (1961), as well as his participation on the selection jury of the brazilian representation on the VIII, IX and X Biennials (1965, 1967, 1969). It was examined, still, Schenberg's participation on the round tables promoted by the International Association of Art Critics on the 1969 and 1971 (X e XI Biennials) editions. The investigation considered by primary sources the original critics of the Mario Schenberg's Center of Documentation Research in Art - ECA/USP written in the defined period, as well as the other books, articles and interviews from the critic; add to this material the interviews with artists, curators and scientists who lived with Mario Schenberg in these two decades. In addition to that, a documental survey was carried out in the Wanda Svevo's Historical Archive from the Biennials Foundation. The critic's presence in the field was due, in first place, by his proximity to the artists and his interest for the art and, in second place, for his capacility of bringing a new view to works of art, which could add the singularity of Mario Schenberg's figure to the Biennial's work of art. In understanding that it was the field's function to promote visibility to the new artists who were starting to develop their work and define new ways for the art, the critic took upon him the role of facilitator on the acceptance of new artists and tendencies on the brazilian representation of the Biennials.
\end{abstract}

Keywords: Mario Schenberg, São Paulo International Biennial, art criticism, 1960s and 1970s. 


\section{Título}

Schenberg y las Bienales

\section{Resumen}

Este estudio objetivó evidenciar la actuación de Mario Schenberg en la organización de las Bienales Internacionales de São Paulo como crítico de arte, en las décadas de 1960 y 1970. Fue investigado su envolvimiento en la Sala Especial del pintor Alfredo Volpi en la VI Bienal (1961), así como su participación en el jurado de selección de la representación brasileña en la VIII, IX y X Bienales (1965, 1967 y 1969). También fue examinada la participación de Schenberg en las Mesas Redondas promovidas por la Asociación Internacional de Críticos de Arte en las ediciones de 1969 e 1971 (X y XI Bienales). La investigación utilizó como fuentes primarias las críticas originales del Centro Mario Schenberg de Documentación de Investigación en Arte - ECA/USP escritas en el período delimitado, así como los demás libros, artículos y entrevistas con el crítico. A este material se agrega las entrevistas realizadas con artistas, curadores y científicos que convivieron con Mario Schenberg en estas dos décadas. Además de eso, fue realizado un levantamiento documental en el Archivo Histórico Wanda Svevo, de la Fundación Bienal. La presencia del crítico en el certamen ocurrió, en primer lugar, en virtud de su proximidad con los artistas y su interés por el arte y, en segundo lugar, por su capacidad de aportar una nueva mirada a las obras de arte, que podría agregar la singularidad de la figura de Mario Schenberg a los cuadros de la Bienal. Al comprender que era función del certamen brindar visibilidad a los nuevos artistas que comenzaban a desarrollar su trabajo y a definir nuevos caminos para el arte, el crítico asumió el rol de facilitador de la aceptación de nuevos artistas y tendencias en la representación brasileña de las Bienales.

Palabras clave: Mario Schenberg, Bienal Internacional de São Paulo, crítica de arte, décadas de 1960 y 1970. 


\section{Lista de Imagens}

Figura 1: MARIO SCHENBERG CERCADO POR OBRAS DE ARTISTAS SOBRE OS QUAIS ESCREVEU. A IMAGEM FOI CAPA DO CATÁLOGO DA EXPOSIÇÃo O MUNDO de MARIO SCHENBERG, NA CASA DAS

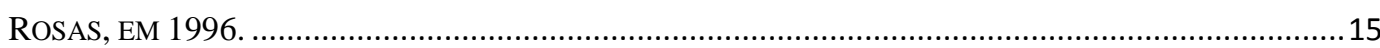

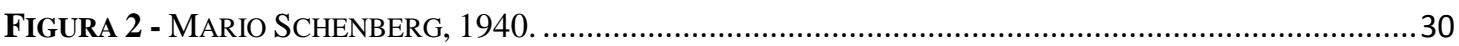

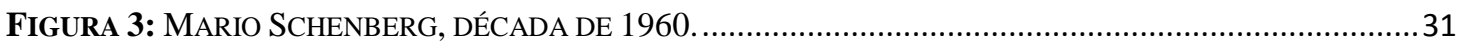

FIGURA 9 - VISTA GERAL DA 1ª BIENAL (1951) ..................................................................................

Figura 4- Pavilhão localizado na Esplanada do Trianon, na Avenida Paulista. Autor não

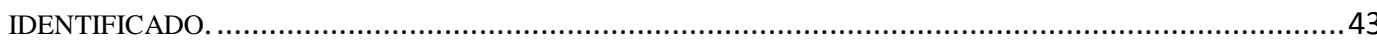

Figura 5 - Fachada do Trianon, onde fol inaugurada a 1a Bienal do Museu de Arte Moderna.

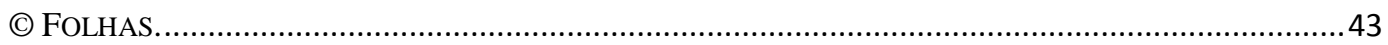

Figura 6 - O CASAl Yolanda Penteado e Ciccillo Matarazzo (À Direita) E ARTURo Profilli (À ESQUERDA) NA $1^{\text {a }}$ BIENAL (1951) @CAV. GIOV. STRAZZA.

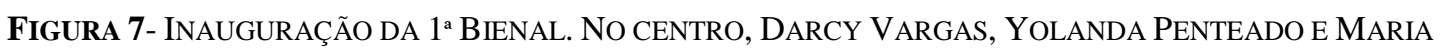
KARESKA. EM SEGUNDO PLANO, DA ESQUERDA PARA A DIREITA: VICTOR BRECHERET, TARSILA DO amaral, Carlos Prado, Robert Tatin, Marcelo Grassmann, Bruno Giorgi, Frans KRAJCBERG E PAULO RoSSI OSIR. ๑ CAV. GIOV. STRAZZA. ........................................................ 44

Figura 8 - MaX Bill, Tripartite unit [Unidade Tripartida], na SeÇão Geral Suíça. Autor Não IDENTIFICADO

Figura 10 - Fotografia do ANTIGo PALACETE SANTA Helena, DEMOLIDO EM 1971, QUANDO DA CONSTRUÇão DA ESTAÇÃO DO METRÔ DA SÉ.

FigURA 11: ALFREDO VOLPI, [COMPOSIÇÃO COM FAIXAS], DÉC. 1960, TÊMPERA SOBRE TELA, 75 X 110,3 CM. ColeÇão Particular. ReProduÇÃo FOTOGR ÁFICA Horst MERKEL.....................................6

Figura 12: ALFREDO VolPi, [Vista DE ITANHAÉM] [MARINHA DE ITANHAÉM], DÉCADA DE 1940, TÊMPERA SOBRE TELA, 45 X 76 CM. COLEÇÃo PARTICULAR. REPRODUÇÃO FOTOGRÁFICA DE AUTORIA DESCONHECIDA.

Figura 13: AlFREDO VolPI, FACHADA COM BANDEIRAS, 1959, TÊMPERA SOBRE TELA, 116 X 72 CM. ACERVO do Museu de ARTE de SÃo PAUlo - MASP, DOAÇÃo de ERNEST WOLF. REPROdUÇão FOTOGRÁFICA: JOÃO MUSA.

Figura 14 - Vista EXTERNA COM OUTDOOR DA VI BIENAL DE SÃo PAUlo. AUtORIa DESCONHECIDA. 62

Figura 11 - Planos em Superfície Modulada Série B (1958), De Lygia Clark, na 5a Bienal (1959). AUTOR DESCONHECIDO.

Figura 12 - LyGia ClARK, SÉRIES Bichos E SUPERfícIES, EM SALA ESPECIAL DA 7ª BIENAL.

Figura 13 - Vão central da 8a Bienal com Vista Para Pinturas de Danilo di Prete. À direita, Rogelio Polesello, CALEIDOSCOPIO [CALEIDOSCÓPIO]. @ ATHAYde DE BARRos.

Figura 14 - HiLdA Hilst em FRENTE aOS PORTÕes da ReCÉm CONSTRUída CASA do SOl. DÉCADA DE 1960.

Figura 15 - HiLdA HILST E MARIO SCHENBERG. DÉCADA DE 1960 ………………………………....76

Figura 16 - MARIo SCHENBERG EM FRENTE À RECÉM CONSTRUídA CASA DO SOL, EM 1965 .................76

Figura 17 - MÁrio SCHENBERG, PROFESSOR E POLítico, AO LADO DE SUA ESPOSA, DEIXANDO A PRISÃo. PUBLICADA EM 25 SET. 1965.

Figura 18 - Gravuras de Maria Bonomi expostas na VIII Bienal de São PaUlo. A artista RECEBEU O PRÊMIO DE MELHOR GRAVADORA NACIONAL NA EDIÇÃO. ................................................ 88

FigURA 19 - MARIA BONOMI, 1965, XILOGRAVURA SOBRE PAPEL DE ARROZ, 130 x 108 .........................8

Figura 20 - ABERTURA da 8a BiENAL COM AS PRESENÇAS DO PRESIDENTE CASTELO BRANCO, Francisco MatarazZo Sobrinho e PaUlo MENDES DE ALMEIDA. AUTOR NÃO IDENTIFICADO. 89 
FigURA 21 - MARIA BONOMI, 1965.

Figura 22 - MARIA BonOMi, BALAdA DO TERror, 1970. XILOGRAVURA EM CORES, 204,8 X 83,3 CM. Museu de ARTE Moderna de SÃo PAUlo. .91

FIGURA 27 - SCHENBERG FOI PARA O CONGRESSO NO JAPÃO. ÚlTIMA HORA - 27/09/1965 - SEGUNDAFEIRA.

FIGURA 28 - SALA ESPECIAL EDWARD HoPPER NA 9a BIENAL (1967) .................................................96

FigURA 29 - SALA ESPECIAL: AMBIENTE U.S.A - 1957/67, COM A OBRA DE JAMES GILl, 'MARILYN'. À ESQUERDA, INTERVENÇÃO DO PÚBLICO FRENTE AO CONTEXTO POLÍTICO DA ÉPOCA. C AGENCIA ESTADO.

Figura 30 - ABERTURA dA 9a BiEnAL. Francisco MATARAZZO SOBrinho E MARIo PEDrosa EM FRENTE À OBRA DE ROBERT RAUSCHENBERG NA SALA ESPECIAL: AMBIENTE U.S.A - 1957/67. AUTOR NÃO IDENTIFICADO.

Figura 31 - "BUM”, 1966, DE MARCELO NiTSCHE (ÓLEO, LÁTEX E CHAPA GALVANIZADA S/ DURATEX E MADEIRA; 109 X 81,5 X 61 CM). COLEÇÃo PinACOTECA DO ESTADO DE SÃO PAULO.....................101

FigURA 32 - GÊNESIS IV, 1967. ESMALTE SINTÉTICO SOBRE TELA, 180 X 220 CM...............................102

Figura 33 - QUiSSAK JÚNIOR, SEM títUlo, 1978. ÓleO SOBRE TELA, 59.00 CM X 75.00 CM. .............105

FIGURA 34 - JASPER JOHNS, TRÊS BANDEIRAS, 1958. ENCAUSTICA SOBRE TELA, 78.42 CM × 115.5 CM, WHITNEY MUSEUM OF AMERICAN ART, NOVA YORK. 106

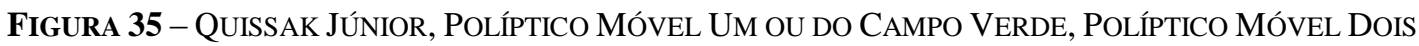
ou do Losango Amarelo, Políptico Móvel Três ou do Círculo AzUl, PolíPtico Móvel Quatro ou da FaiXa Branca, Políptico Móvel Cinco ou DA PÁtria. 1967, Óleo SOBRe tela.

Figura 36 - HÉlio OITICICA, B15 BÓlidE VIDRO 4 - TERRA, 1964, CUBA DE VIDRO, TERRA E TECIDO. PROJETO HÉlio OITICICA (RIO DE JANEIRO, RJ). REPRODUÇÃO FOTOGRÁFICA AUTORIA DESCONHECIDA

Figura 37 - Heitor dos PrAZEREs, MOENDA, 1951. Óleo SOBRE TELA, 65.00 CM X 81.00 CM. COLEÇÃo do Museu de Arte ContemporÂneA de SÃo PAulo. Foto: RoMulo Fialdini........................116

Figura 38 - Waldomiro de DEUS, SEM títUlo, 1997. Óleo SOBRE TELA, 46 X 55 CM......................120

Figura 39 - WALDOMIRO DE DEUS, FogUETE CARIOCA NA LUA, 1966. ÓlEO SOBRE TELA, 193.00 CM X 98.00 CM. COLEÇÃO PARTICULAR. FoTO: SÉRGIO GUERINI......................................................121

FigURA 40 - ChICO AS SILVA, A LUTA DOS DRAGÕES, 1967. Foto: RoMUlo FIALDINI. .........................122

Figura 41 - José ANTÔNIO dA Silva, RESSUREIÇÃO, 1967. ÓleO SOBRE TELA, 58.70 CM X 72.00 CM. MuSEU de ARTE SACRA DE SÃo PAUlO - MAS. Foto: RoMUlo FIALDINI...................................122

FIGURA 33 - A NOITE dOS GÂNGSTERS, 1967, DE JOÃO PARISI FILHO..................................................129

Figura 43 - Flávio de CARVAlho, Retrato de Mario SCHENBERG, 1968. Óleo sobre tela, 98.00 CM X 67.00 CM. COLEÇÃO PARTICULAR................................................................................... 140

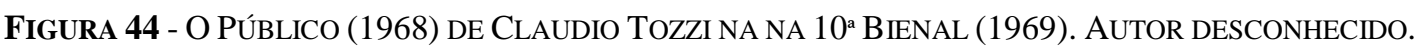

Figura 45 - O PÚBlico (1968) de Claudio Tozzi na 30 × Bienal (2013) @LLe Eloy / FundaÇÃo

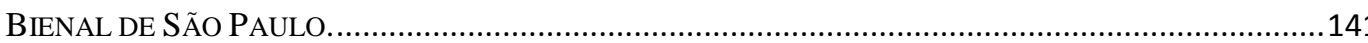

Figura 46 - OndAS PARADAS DE PROBABILIDADE (1969) DE MiRA SCHENDEL NA 22ª BIENAL (1994). AUTOR DESCONHECIDO.

Figura 47 - Ondas PARAdAS DE PROBABILIDAdE (1969) DE MiRA SCHENDEL NA 30 × BIENAL (2013) CLEO Eloy / FundAÇÃo BIENAL DE SÃo PAULO.

Figura 48 - Vista da SAla EsPeCial: Novos VAlORES Brasileiros. À FrEnTE, OBRA DE CARMELA GROSS, 'ESPUMA' (1969). AUTOR DESCONHECIDO.

Figura 49 - Espuma (1969) DE CARMEla Gross NA 30 × BienAL (2013) @ CLEO Eloy / FundAÇÃo BIENAL DE SÃO PAULO.

Figura 50 - BolHA AMARELA (1967-1968) DE MARCELO NitSCHE NA 10a BIENAL (1969) .................144

Figura 51 - Bolha AMAREla (1967-1968) DE MARCElo Nitsche NA $30 \times$ Bienal (2013) CLeo Eloy / FundAÇão BiENAL dE SÃo PAULO. 
FigURA 52 - VISTA GERAL DA 10a BIENAL. AUTOR NÃO IDENTIFICADO................................................146

FigURA 53 - FACHADA DA 10a BIENAL. AUTOR NÃO IDENTIFICADO. ................................................146

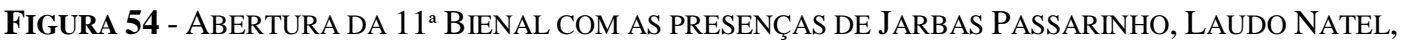

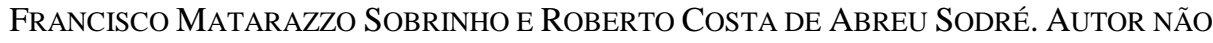
IDENTIFICADO. 162

Figura 30 - X BIENAL DE SÃo PAULO, EM 1969. EM PRIMEIRO PLANO, ESTRUTURAS TEMPORÁRIAS, EM FORMA DE OCA, CONSTRUÍDAS PARA ABRIGAR OS EVENTOS DA II BIENAL DE CIÊNCIA E HUMANISMO.

Figura 31 - JosÉ Leite LoPeS E MARIO SCHENBERG No INSTITUTO DE Fí́sICA DA USP, S/D. ..............169

Figura 32 - MARIO SCHENBERg E AMÉLIA IMPÉRIO HAMBURGUER. DÉCADA DE 1960 ........................180

Figura 33 - Mario Schenberg autografando o livro Pensando a Física. 36a Reunião anual DA SBPC, REALIZADA NA USP. SÃo PAULO, JULHO DE 1984. 180

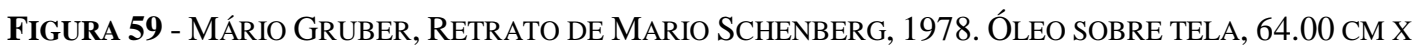
53.00 CM. NO PERÍODO DELIMITADO NESTA PESQUISA, O ARTISTA PARTICIPOU DA BIENAL NOS ANOS

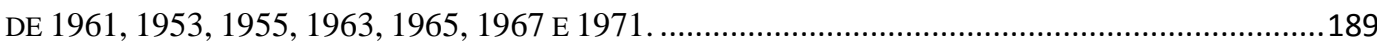

Figura 60 - Mario SCHENBERG, S. D. AUtora: ANa Clara GUERrini SCHENBERG. ..........................190

Figura 61 - Yoshiya TAKaOKa, Retrato de Mario SCHENBERG, 1962, Óleo SOBRE TEla, 46 X 38 CM. ColeÇão Particular. Reprodução Fotográfica Rubens Chiri/Itaú CUltural. O ARTISTA PARTICIPOU DAS BIENAIS DE 1951 E DE 1959.

FigURA 62 - CAPA DO CATÁLOGO DA PRIMEIRA EXPOSIÇÃo INDIVIDUAL DE ALFREDO VOLPI. NELE, CONSTAM O TEXTO INTRODUTÓRIO ESCRITO POR SCHENBERG E FOTOS DE ALGUMAS TELAS, BEM COMO A LISTA DE OBRAS.

Figura 63 - VI BIENAL DE SÃo PAULO. REPRODUÇÕES DE QUADROS DE ALFREDO VOLPI. AUTORIA DESCONHECIDA. A TELA FOI IDENTIFICADA, TRATA-SE DE FACHADA COM BANDEIRAS, 1959, TÊMPERA SOBRE TELA, 116 X 72 CM. ACERVo do Museu de ARTE de São PAUlo - MASP, DOAÇÃO DE ERNEST WOLF.

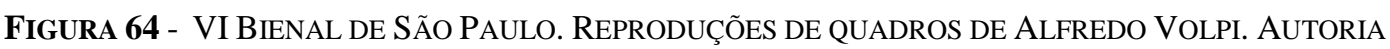
DESCONHECIDA.

Figura 65 - Planta da sala esPecial dedicada a Alfredo Volpi. NesSe ESPaÇo, foram COLOCADAS 95 AS OBRAS DO ARTISTA.

Figura 66 - O PINTOR AFREDO VolPI, NA PLATÉIA, EM CONFERÊNCIA SOBRE SUA OBRA. MUSEU DE ARTE Moderna, EM SÃo PAULO, EM JUNHO DE 1956.

FiguRA 67 e 68 - THEON SPANOUdIS E MARIO SCHENBERG EM CONFERÊNCIA SOBRE A OBRA DE Alfredo VolPI. MuSEu de ARTE Moderna, EM SÃo PAUlo, EM JUNHO DE 1956.

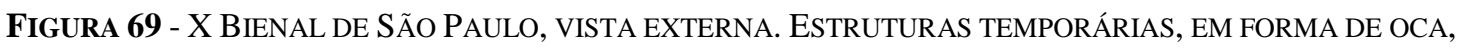
CONSTRUÍDAS PARA ABRIGAR OS EVENTOS DA II BIENAL DE CIÊNCIA E HUMANISMO. AUTORIA DESCONHECIDA 


\section{Sumário}

INTRODUÇÃO

SALA ESPECIAL DE ALFREDO VOLPI ..............................................................................................32

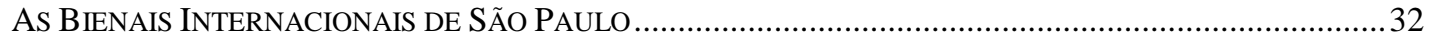

VI BIENAL (1961) - OS DESAFIOS DA ORGANIZAÇÃO ……………………………………………..... 46

JÚRI DE SELEÇÃO: EM DEFESA DOS ARTISTAS ...............................................................63

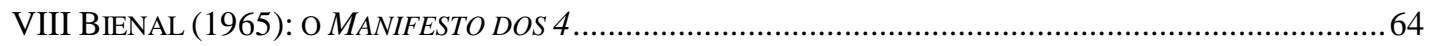

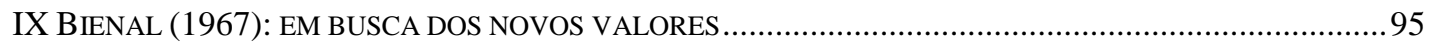

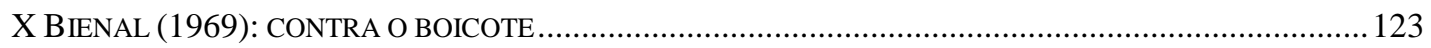

MESAS E SEMINÁRIOS: O LUGAR DO DEBATE ..............................................................147

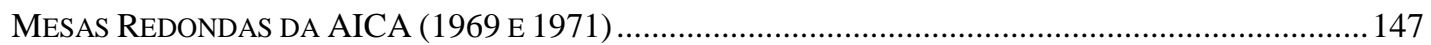

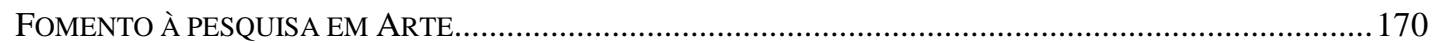

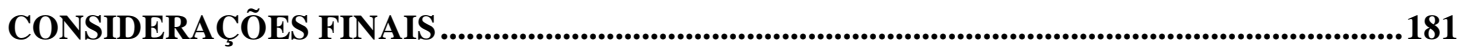

REFERÊNCIAS BIBLIOGRÁFICAS........................................................................................ 191

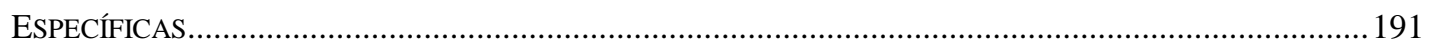

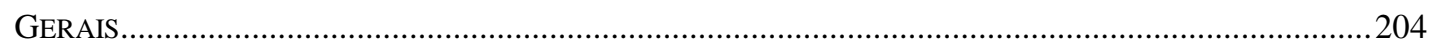

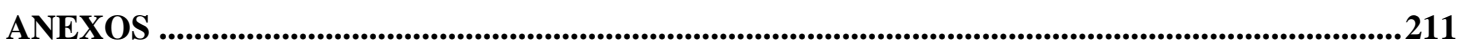

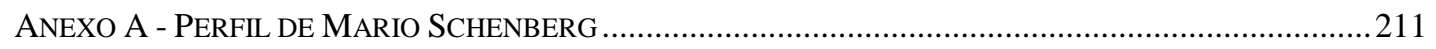

ANEXo B - CURRí́cuLO ARTí́stICO DE MARIO SCHENBERG ..............................................................2213

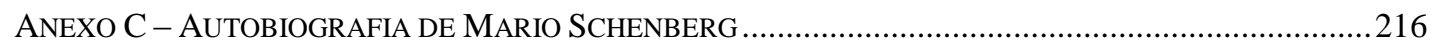

ANEXo D - HistóRICO DO CENTRO MARIO SCHENBERG DE DOCUMENTAÇÃo DA PESQUISA EM ARTE -

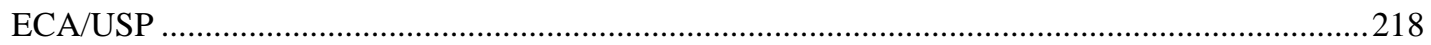

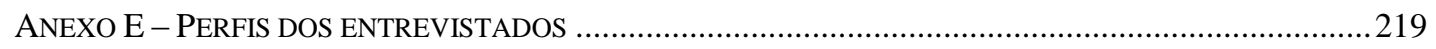

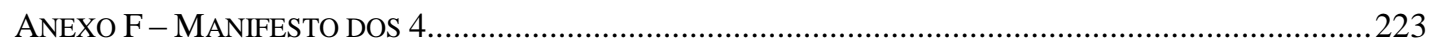

ANEXo G - CARTA DE Mário PEdRosa PARA MARIo SCHENBERG, 02/02/1961 .................................224

ANEXO H - Ultima HoRA, 2a EDIÇÃO, SÃo PAUlO, 25/03/1964 (CAPA). ........................................22

ANEXO I - AUTORIZAÇÃO PARA SAÍDA DO PAÍ́. JUSTIÇA MILITAR, 02/08/1965 .................................226

ANEXO J - YOSHIYA TAKAOKA, RETRATO DE MARIO SCHENBERG, 1962 _..........................................227

ANEXO K - CAPA DO CATÁLOGO DA PRIMEIRA INDIVIDUAL DE ALFREDO VOLPI ................................228

ANEXO L - VI BIENAL - REPRODUÇÃO DE OBRA DE ALFREDO VOLPI. .................................................222

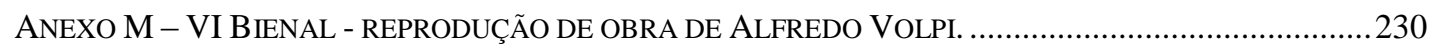

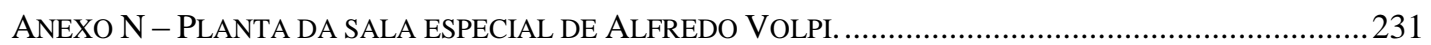

ANEXO O - ALFREDO VOLPI, THEON SPANUdIS E MARIO SCHENBERG, 18/06/1056 ............................2232

ANEXo P - X BIENAL DE SÃo PAUlo, VISTA EXTERNA. II BIENAL DE CIÊNCIA E HuMANISMO...........233

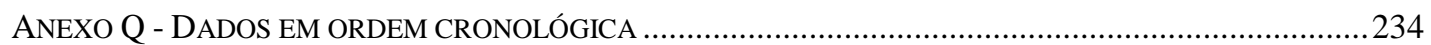


Figura 1: Mario Schenberg cercado por obras de artistas sobre os quais escreveu. A imagem foi capa do catálogo da exposição $\mathbf{O}$ Mundo de Mario Schenberg, na Casa das Rosas, em 1996.

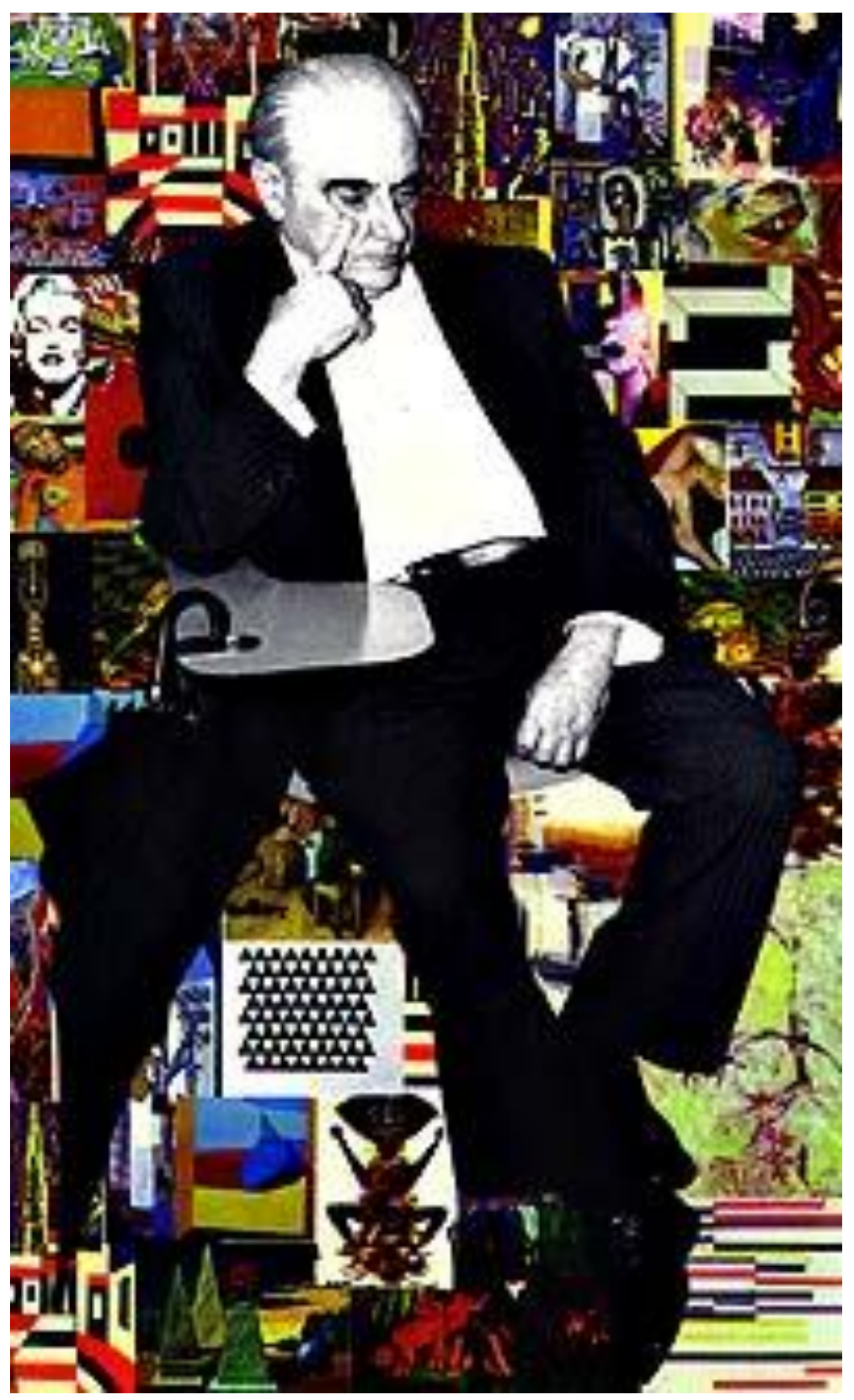

Fonte: AGUILAR, José Roberto. O mundo de Mario Schenberg. São Paulo: Casa das Rosas, 1996. 


\section{Introdução}

"Homem dos sete instrumentos", nas palavras de Scarlet Marton (2004, p. 155), Mario Schenberg (Recife, PE, 1914 - São Paulo, SP, 1990) está entre os mais renomados cientistas que o país já teve, além de ter se dedicado à atividade política e à crítica de $\operatorname{arte}^{2}$. O interesse pela arte, pela cultura e pelo ser humano fez de Schenberg uma personalidade muito querida e respeitada por artistas, intelectuais e críticos, principalmente entre as décadas de 1940 e 1980, período no qual se dedicou à crítica e a descobrir e incentivar novos artistas. Em sua cosmovisão, arte, ciência e política não estavam separadas, mas em proximidade e consonância. Nesse sentido, pode-se situar a figura de Schenberg numa linhagem de intelectuais cuja amplitude de interesses contribuiu para a significância de sua atuação:

Goethe foi, acima de qualquer coisa, um grande observador de plantas e possui verdadeiros tratados de cunho "científico" a respeito da Botânica, isso sem contar sua legítima teoria a respeito das cores. Bachelard foi matemático, acima de qualquer coisa. Einstein foi amante das artes e tocava com grande esplendor violino. Primo Levi, grande escritor, foi químico. Guimarães Rosa foi um grande médico que soube, talvez, mais do que ninguém, ouvir os rios e captar suas profundezas. Pedro Nava, grande memorialista, também foi médico. Mia Couto, a maior expressão, atualmente, da literatura africana, é biólogo. (FUSARO, 2014, p. 11-12).

É sobre o Schenberg crítico, voltado à cultura e às artes, que esta tese se voltará. Colocando de modo mais preciso, o objeto desta pesquisa é a atuação de Mario Schenberg nas bienais de São Paulo nas décadas de 1960 e 1970. O foco da atenção será, mais exatamente, a atuação do crítico nos júris de seleção da representação brasileira, dos quais participou nas bienais de 1965, 1967 e 1969. Em investigações de

\footnotetext{
${ }^{2}$ Alberto Luiz da Rocha Barros esclareceu que, no início de sua carreira, Schenberg trabalhou com Enrico Fermi na Universidade de Roma e com Wolfgang Pauli em Zurique. Esses dois cientistas introduziram na física o neutrino, uma partícula com carga elétrica e massa evanescente (BARROS, Alberto Luis da Rocha. Schenberg: nada do que é humano lhe era estranho. In: Estudos Avançados, 11(5), 1991, p, 195). Na década de 1940, trabalhando com George Gamow nos Estados Unidos, Schenberg teve a intuição de introduzir o neutrino para explicar o colapso que inicia o processo explosivo em estrelas novas e supernovas, uma vez que os estudos dos quais Gamow partira tinham sido escritos antes de se ter ideia do neutrino. O que motivou o nome Processo Urca foi uma comparação feita por Gamow: este observou que as estrelas perdiam neutrinos assim como jogadores perdiam dinheiro no Cassino da Urca, famoso na época, que havia visitado com Schenberg ao conhecer o Rio de Janeiro. (SCHENBERG, Mario. Formação da Mentalidade Científica. In Estudos Avançados, 12(5), 1991, p. 140).
} 
nível de mestrado ${ }^{3}$, às quais o presente estudo deu continuidade, foi possível constatar que nas bienais de São Paulo o crítico se posicionou sempre a favor da arte e dos artistas, defendendo a abertura do certame àqueles em começo de carreira, bem como aos que encontravam novos caminhos nas tendências nascentes.

Se, por um lado, evidenciou-se que o envolvimento do crítico Mario Schenberg nas bienais de São Paulo foi importante e se deu num momento decisivo da história da mostra, a efervescente e tumultuada década de 1960, por outro, algumas perguntas continuam à espera de respostas, entre elas: como um cientista tomou parte na organização do júri de seleção da Bienal de São Paulo? Quais foram suas intervenções e posicionamentos político-estéticos dentro da organização do evento? São esses questionamentos e outros adjacentes que esta pesquisa objetiva responder.

Mario Schenberg participou também de momentos marcantes do cenário artístico da década de 1960, tais como as exposições Opinião 65 e Propostas 65. Nesse ínterim, o crítico manteve contato com artistas como Lygia Clark, Hélio Oiticica, Mira Schendel, Maurício Nogueira Lima, José Roberto Aguilar, entre outros.

O crítico tornou-se, nas décadas de 1960 e 1970, teórico do Novo Realismo ${ }^{4}$. Por meio de seus textos, constatou-se que esteve presente nos debates sobre essa tendência e manteve proximidade com artistas cujos trabalhos se vinculavam a ela. $\mathrm{O}$ artista Maurício Nogueira Lima apontou que o crítico deu muito apoio aos grupos de vanguarda nos anos de 1960, escrevendo sobre eles e refletindo acerca de suas características e intenções ${ }^{5}$. Nas bienais da década de 1960, período de grandes impasses e de crise da Bienal, o crítico esteve presente em todas as suas edições, salvo a de $1963^{6}$. Schenberg passava, então, a conhecer as bienais por dentro.

\footnotetext{
${ }^{3}$ PISMEL, Ana Paula Cattai. Schenberg: em busca de um Novo Humanismo. São Paulo: Programa de Pós-Graduação Interunidades em Estética e História da Arte, Universidade de São Paulo, 2013 (dissertação de mestrado).

${ }^{4}$ OLIVEIRA, Alecsandra Matias de. Schenberg: crítica e criação. São Paulo: Edusp, 2011, p.119.

5 "Nessa época, a principal característica de Schenberg foi a de apoiar os grupos de vanguarda que tentavam subverter a arte brasileira; principalmente na década de 60, quando eu e o Schenberg mais colaboramos com esses grupos. [...] Mário nos deu um grande apoio, escrevendo vários artigos; mas, infelizmente, não tinha acesso aos meios de comunicação (jornais, televisão etc.). Os artigos eram publicados em catálogos de exposições e, às vezes, uma ou outra revista cedia espaço para ele expor o seu pensamento". LIMA, Maurício Nogueira. Mario Schenberg: incentivador e crítico. In: AJZENBERG, Elza (org.). Schenberg - Arte e Ciência. São Paulo: ECA USP, 1995, p. 42. Com relação às citações diretas neste estudo, optou-se por manter sempre a grafia original da fonte, conforme se verá adiante. ${ }^{6}$ AJZENBERG, Elza. Mario Schenberg: o crítico. In: AGUILAR, José Roberto. O mundo de Mario Schenberg. São Paulo: Casa das Rosas, 1996. Em 1953, Schenberg retornou ao Brasil após uma estadia de cinco anos na Bélgica, nos quais lecionou na Universidade de Bruxelas, dedicando-se às atividades científicas. Foi nomeado Diretor do Departamento de Física da então chamada Faculdade de Filosofia,
} 
Sua primeira participação se deu na VI Bienal, em 1961, quando o crítico organizou a retrospectiva do artista Alfredo Volpi. A sexta edição da mostra era a última ligada ao Museu de Arte Moderna de São Paulo (MAM SP). Foi também a derradeira edição que contou com uma organização centralizada na figura de um diretor geral, função ocupada então por Mário Pedrosa ${ }^{7}$. A retrospectiva de Alfredo Volpi ocupou uma das salas especiais da representação brasileira ${ }^{8}$. O crítico já era, na época, um dos maiores conhecedores da obra do artista, tendo sido o primeiro a perceber, por volta dos anos de 1940, a importância da produção do pintor-operário 9 . Tendo então 48 anos, o pintor começou a ter colecionadores que admiravam profundamente o seu trabalho ${ }^{10}$.

Porém, surgem algumas indagações sobre essa trajetória: por que foi Schenberg o crítico escolhido para organizar a sala especial? Como se deu esse trabalho de organização? Ocorreram dificuldades? Qual foi a repercussão da mostra?

Para Mario Schenberg, cuja esfera de atuação englobava sua atividade acadêmica como docente na então FFCL (Faculdade de Filosofia, Ciências e Letras da USP), a militância política e a crítica de arte, o ano de 1965 foi bastante intenso e repleto de acontecimentos, visto que o crítico teve que lidar com a perseguição ${ }^{11}$. As complicações decorrentes da política vigente no país prejudicaram também o exercício de suas atividades como pesquisador e docente na Universidade de São Paulo. Nos anos seguintes, Mario Schenberg envolveu-se com a organização das bienais, dessa vez como membro do júri nacional de seleção. Participou, assim, da organização da VIII, IX e X bienais de arte de São Paulo (em 1965, 1967 e 1969), para as quais foi sempre eleito pelos próprios artistas.

Ciências e Letras da USP, o que diminuiu sua disponibilidade de tempo para a crítica de arte. Em 1961, quando deixou o cargo, ele pôde retomá-la de modo mais sistemático, principalmente por meio do contato com Alfredo Volpi e Mário Pedrosa. Até 1969, quando foi afastado da USP, atuou no meio artístico com menor intensidade, o que não quer dizer que sua crítica de arte tenha sido menos significativa.

${ }^{7}$ Da VII Bienal em diante, a organização do evento contaria apenas com comissões de assessoria e, a partir da XI Bienal, em 1971, com uma assessoria técnica. Cf. ALAMBERT, Alambert \& Polyana CANHÊTE. Bienais de São Paulo: da era do museu à era dos curadores. São Paulo: Boitempo, 2004. ${ }^{8}$ FUNDAÇÃO BIENAL. VI Bienal (catálogo de exposição). São Paulo: Fundação Bienal, 1961. Alfredo Volpi dividiu com Di Cavalcanti o Prêmio Nacional de Pintura na II Bienal, em 1953, escolha que se deu no contexto do debate entre o realismo social e o abstracionismo emergente. Cf. AMARANTE, Leonor. As Bienais de São Paulo: 1951 a 1987. São Paulo: Projeto, 1989.

9 AJZENBERG, Elza. Mario Schenberg: o crítico. In: AGUILAR, José Roberto. O mundo de Mario Schenberg. São Paulo: Casa das Rosas, 1996.

${ }^{10}$ AMARAL, Aracy. A visão do colecionador. In Volpi: pequenos formatos. São Paulo: Museu de Arte Moderna de São Paulo, 2016, p. 9.

${ }^{11}$ Na década de 1960, Mario Schenberg foi membro titular do Comitê Central do Partido Comunista. Cf. Dina Kinoshita. A Política para Mario Schenberg, s.p. (texto digitado - Arquivo do Centro Mario Schenberg de Documentação da Pesquisa em Artes - ECA USP). 
A VIII Bienal abriu as portas ao grande público um ano e meio depois do golpe militar de 1964 e a repressão já começava a fazer parte do horizonte cultural e político, repercutindo imediatamente na estrutura de poder da USP. Mario Schenberg não pôde comparecer à inauguração porque fora decretada sua prisão preventiva. Único latinoamericano convidado para um importante congresso no Japão, ele somente conseguiu participar do evento por causa da repercussão de sua prisão; seu status de renomado cientista projetou internacionalmente a arbitrariedade do regime militar ${ }^{12}$. Durante a cerimônia de premiação da VIII Bienal, a artista Maria Bonomi, ao ir receber seu prêmio de Melhor Gravadora Nacional, entregou ao presidente da república, o militar Humberto Castelo Branco, um documento que ficou conhecido como Manifesto dos 4. Assinado por vários artistas e intelectuais, a carta continha o pedido para que o presidente intercedesse em favor de Mario Schenberg, bem como de Florestan Fernandes, João Cruz Costa e Fernando Henrique Cardoso (também docentes da USP ${ }^{13}$ ).

Ficam as questões: como foi possível a Mario Schenberg participar das diversas reuniões do júri tendo a possibilidade de ser preso? Seu nome foi bem aceito pela Bienal? O que teria motivado os artistas a escolherem seu nome para a função? Uma vez dentro do júri de seleção, como Schenberg se colocou?

Em 1967, a pop art norte-americana, que marcou presença na Bienal anterior, deu o tom da mostra. Não foi por acaso que a IX Bienal ficou conhecida como a Bienal do Pop. Apesar da boa repercussão da sala dos EUA, outros países também trouxeram desdobramentos da pop art ${ }^{14}$. O júri de seleção da IX Bienal de São Paulo foi constituído por dois nomes indicados pela diretoria executiva da Fundação Bienal, dois escolhidos pelos artistas por meio de votação e um quinto escolhido por esses quatro. Juntamente com José Geraldo Ferraz, Mario Schenberg foi eleito pelos artistas (aquele com 41 votos, este com $32^{15}$ ). À época, surgiu com intensidade a polêmica em torno da aceitação

\footnotetext{
${ }^{12}$ Cf. ClEMENTE, José Eduardo Ferraz. Ciência e política durante a ditadura militar: o caso da comunidade brasileira de físicos (1964-1979). Salvador: Universidade Federal da Bahia, Instituto de Física, 2005. (dissertação de Mestrado); e AGUILAR, José Roberto. O mundo de Mario Schenberg. São Paulo: Casa das Rosas, 1996.

${ }^{13} \mathrm{O}$ texto integral do Manifesto dos 4 pode ser encontrado integralmente nos Anexos desta tese.

14 AMARANTE, Leonor. As Bienais de São Paulo: 1951 a 1987. São Paulo: Projeto, 1989. Um dos destaques da representação dos EUA foi a sala especial dedicada ao pintor Edward Hopper, falecido cinco messes antes da exposição e, então, recentemente reconhecido como precursor da pop art.

${ }^{15}$ MAURÍCIO, Jayme. Bienal: eleitos dos artistas. Correio da Manhã, 6 jun. 1967.
} 
de Mario Schenberg como membro do júri de seleção, pois, apesar de ser considerado como crítico pelos artistas, seu nome foi recebido com dúvidas pela Fundação Bienal ${ }^{16}$.

A participação de Schenberg nas bienais se deu por força de sua atuação ao lado dos artistas, que confiavam nele e acreditavam que poderia defender seus interesses no júri do evento ${ }^{17}$. Entre os críticos de arte, ele se deparava com o preconceito, em parte devido à sua formação e metodologia peculiar, em parte decorrente do seu posicionamento político. Diante desses fatos, pode-se perguntar: como Schenberg viu as novas propostas que os artistas enviaram à Bienal? Seus critérios eram distintos daqueles dos demais membros do júri?

No fim de 1968 sobreveio o endurecimento da censura. O AI-5, decretado em 13 de dezembro de 1968, restringiu atividades políticas e manifestações culturais ${ }^{18}$. Repercutindo em diversas instituições públicas federais, estaduais e municipais, o decreto atingiu, no início do ano seguinte, vários professores e funcionários da USP, que foram demitidos ou aposentados compulsoriamente em abril de 1969. Entre eles estava o Professor Mario Schenberg, que desde então passou a se dedicar com mais ênfase à crítica de arte, uma vez que foi impedido até mesmo de frequentar bibliotecas e ambientes universitários. Por sua vez, a X Bienal foi marcada pelo boicote internacional, a que aderiram artistas, críticos de arte e intelectuais. Todas as fases de sua realização foram prejudicadas; com maior ou menor dificuldade, porém, os obstáculos foram contornados pela comissão técnica e pelo júri de seleção, que organizou várias salas especiais, além da sala geral da representação brasileira.

Artistas e intelectuais se dividiam, basicamente, em duas posições: aderir ou não ao boicote, ou seja, dar aval ou protestar contra o sistema político que amparava a Bienal $^{19}$. Apesar de assumidamente comunista, Mario Schenberg optou por levar adiante sua função de jurado naquela edição. O crítico não apenas se posicionou contra o boicote, como organizou a sala Novos Valores, assinando o texto de apresentação no catálogo da mostra ${ }^{20}$. Entretanto, ao participar da Bienal e levar adiante sua colaboração

\footnotetext{
${ }^{16}$ Schenberg fica. Correio da Manhã, 6 jun. 1967.

${ }^{17}$ OLIVEIRA, Alecsandra Matias de. Schenberg: Crítica e Criação. São Paulo: EDUSP, 2011.

${ }^{18}$ Folha registrou trajetória de FHC, da USP à Presidência. Folha de S. Paulo, 18 jun. 2011.

${ }^{19}$ FUNDAÇÃO BIENAL DE SÃO PAULO. 50 anos Bienal de São Paulo: 1951-2001. (catálogo de exposição) São Paulo: Fundação Bienal, 2001.

20 AMARANTE, Leonor. As Bienais de São Paulo: 1951 a 1987. São Paulo: Projeto, 1989, p. 184. Cf. Texto de apresentação da sala especial em SCHENBERG, Mario. Novos Valores. In: FUNDAÇÃO BIENAL. X Bienal. (catálogo de exposição) São Paulo: Museu de Arte Moderna de São Paulo, 1969, p. 445 .
} 
no júri de seleção e organização geral, o crítico não estava dando seu aval ao Estado ${ }^{21}$. Mas o que fez com que Mario Schenberg não aderisse ao movimento de boicote à Bienal? Tendo em vista que foi reduzido o número de críticos e artistas que se propunham a seguir participando do evento, que atitudes tiveram que tomar para concretizar a organização daquela edição?

Após questionar diversos pontos da organização do certame e reivindicar participação no júri de seleção da X Bienal, a Associação Internacional de Artistas Plásticos (seção brasileira) recebeu da Fundação Bienal o convite para enviar uma lista com cinco nomes eleitos por seus quadros sociais, dentre os quais seria escolhido um representante para integrá-lo ${ }^{22}$. Foi enviado, contudo, apenas um nome, o de Mario Schenberg ${ }^{23}$. Nessa edição da Bienal, portanto, o crítico integrou o júri com o apoio dos artistas, mesmo que não tenha ocorrido uma eleição organizada pela Fundação Bienal ${ }^{24}$.

A XI Bienal, em 1971, marcou, para Aracy Amaral, o início dos “anos baixos” das bienais, na medida em que, cada vez mais, Ciccillo delegava a amigos empresários, e não a profissionais especializados, a concepção desses eventos ${ }^{25}$. Sua linha geral era a comemoração dos vinte anos da mostra, realizada em clima de retrospectiva, homenageando a si própria. Nesse espírito, foram organizadas diversas salas especiais dedicadas a artistas premiados desde 1951, contrariando o propósito maior do certame: dar visibilidade às tendências mais recentes da arte nacional e internacional. Nessa ocasião, Mario Schenberg não integrou o júri de seleção, mas fez parte de uma mesaredonda semelhante à realizada na Bienal anterior. Em depoimento, Schenberg ${ }^{26}$

\footnotetext{
${ }^{21}$ Cf. AMARANTE, Leonor. As Bienais de São Paulo: 1951 a 1987. São Paulo: Projeto, 1989. O livro de Leonor Amarante era, até o momento, a única fonte que permitia examinar o posicionamento de Mario Schenberg nessa ocasião. Na presente pesquisa, uma entrevista com o curador Fábio Magalhães - que conviveu com o crítico e estava inserido na discussão suscitada pelo boicote à bienal - possibilitou obter novas fontes primárias a esse respeito. Agradecimentos são devidos, ainda, a Alecsandra Matias de Oliveira, Polyana Canhête e Francisco Alambert pela contribuição nesse ponto.

${ }^{22}$ Carta de Francisco Matarazzo Sobrinho a Maurício Nogueira Lima (Presidente da AIAP), datada de 2 de maio de 1969. Arquivo Histórico Wanda Svevo, Fundação Bienal.

${ }^{23}$ Carta de Maurício Nogueira Lima (Presidente da AIAP) a Francisco Matarazzo Sobrinho, datada de 16 de maio de 1969, p. 1 (foi mantida a grafia original). Arquivo Histórico Wanda Svevo, Fundação Bienal. ${ }^{24}$ Como membro do júri de seleção da X Bienal, Mario Schenberg participou, ainda, de uma mesaredonda, para a qual foram convidados críticos de arte do Brasil e do exterior. Seu objetivo era discutir aspectos da organização e da premiação das bienais, com vistas a sua reformulação. Cf. Críticos de arte vão debater reformulação das bienais. Nota enviada à imprensa (documento não datado). Arquivo Histórico Wanda Svevo, Fundação Bienal.

${ }^{25}$ AMARAL, Aracy. Bienais ou Da impossibilidade de reter o tempo. Revista USP, São Paulo, n. 52, p. 16-25, dez./fev. 2001-2002.

${ }^{26}$ SCHENBERG, Mario. Depoimento. In: AJZNBERG, Elza Schenberg - Arte e Ciência. São Paulo: ECA/USP, 1995, p. 142
} 
apontou o motivo pelo qual não pôde continuar envolvido na organização das edições posteriores à de 1969:

Eu, que já tinha organizado a primeira exposição de Volpi em 1944, organizei em 61 a sua primeira retrospectiva. Depois disso, começaram a votar para que eu fizesse parte dos júris de seleção das Bienais. O primeiro júri que integrei foi em 1965, depois 67 e 69. E, a partir daí, a Bienal me aplica o Ato 75.

Esse testemunho dá a entender que Mario Schenberg teria sido eleito pelos artistas, mas sua atuação foi impedida pela Bienal de modo oficial? Com relação à participação do crítico na mesa-redonda de críticos de arte, cabe perguntar: quais eram as proposições de Schenberg?

Outro fato notável era a ausência de um dos mais eminentes cientistas do país na Bienal de Ciência e Humanismo, promovida paralelamente às bienais de Arte. Essa segmentação das bienais teve início em 1967, concomitantemente à IX Bienal de Arte de São Paulo, projetada sob a forma de um Simpósio Mundial de Integração CiênciaHumanismo, do qual participaram cientistas do Brasil e do exterior. Segundo Ciccillo, a finalidade da I Bienal de Ciência e Humanismo era "atrair para o nosso País a discussão dos temas científicos mais importantes da atualidade ${ }^{27}$ ". A idealização do certame teve em vista a integração entre as Artes e as Ciências e foi a primeira do gênero na América Latina, gerando grande repercussão na época.

Ao longo das edições que aconteceram dentro do período analisado, críticos de arte (como Vilém Flusser) e físicos brasileiros da USP (como José Goldemberg) tiveram voz nas bienais de Ciência e Humanismo. Diante do exposto, cabe a questão: por que Mario Schenberg, físico teórico de carreira internacional e crítico de arte, que tinha tanto a contribuir nas discussões promovidas e, além de tudo, esteve envolvido na organização das Bienais de Artes Plásticas por toda a década de 1960, não tomou parte no evento, seja em sua organização, seja como convidado?

Já foi apontado que o crítico acessou as bienais por meio de sua popularidade entre os artistas, uma vez que foi escolhido por Alfredo Volpi para realizar a sala especial do artista na edição de 1961 e, depois, com a eleição para o júri de seleção da representação brasileira. Se ainda for levado em conta o fato de que seu perfil foi

\footnotetext{
${ }^{27}$ S. Paulo abrigará Bienal de Ciência. O Estado de S. Paulo, 2 jun. 1967.
} 
recebido com reserva e polêmica por parte da Bienal, pode-se levantar a hipótese de que Mario Schenberg era um elemento estranho ao contexto. Sendo assim, podem ser feitas as seguintes questões: uma vez dentro da organização do certame, como o crítico se posicionou? Quais dificuldades ele enfrentou? Como ele se colocava em relação às polêmicas e impasses que a mostra vivia? Como defendia suas convicções nos espaços de debate e nos júris de seleção?

A atuação de Mario Schenberg como crítico de arte nas bienais de São Paulo é o objeto da presente pesquisa, apontando para um vasto campo de investigações. Vale assinalar que não existem estudos anteriores dedicados a situar e analisar detidamente a atuação do crítico quando de seu envolvimento com a organização certame, ocupando espaço de destaque na reflexão acerca da crise da Bienal.

Angariando críticas e elogios ${ }^{28}$ desde sua primeira edição em 1951, considerase que as bienais foram eventos representativos das tendências das artes plásticas nos anos de 1960 e 1970, indicando a presença e a ausência de artistas, críticos e intelectuais como, por exemplo, na edição de 1969, com o início do boicote internacional. Nesse horizonte, é importante contextualizar brevemente o cenário artístico da década de 1960, marcada por intensos debates no campo da arte, bem como por acontecimentos agudos no campo da política. Na segunda metade da década de 1950, o otimismo proveniente do plano de desenvolvimento do governo de Juscelino Kubitschek e da relativa estabilidade política do período configurou um terreno propício para a arte concreta, fortemente pautada pela racionalidade e pela proximidade com a tecnologia ${ }^{29}$. Já a década de 1960 viu a mudança de expectativa decorrente do regime militar, um dos motivos do teor de contestação que a arte do período veio a ter.

Após o debate abstração versus figuração, que marcou a tensão entre a arte concreta e o realismo regionalista social pregado pelo Partido Comunista nos anos de 1950, a década seguinte presenciou o enfraquecimento do abstracionismo geométrico e do expressionismo abstrato (até então, uma vedete internacional) em nome de desdobramentos mais próximos da Pop Art e do Nouveau Réalisme europeu, além das

\footnotetext{
${ }^{28}$ Cf. Arquivo Wanda Svevo/Fundação Bienal; ALAMBERT, Alambert \& Polyana CANHÊTE. Bienais de São Paulo: da era do museu à era dos curadores. São Paulo: Boitempo, 2004. e AMARANTE, Leonor AMARANTE, Leonor. As Bienais de São Paulo: 1951 a 1987. São Paulo: Projeto, 1989.

${ }^{29}$ A arte concreta representou, até os anos de 1960, a principal alternativa à forte presença do realismo oficial, regionalista, propagado pela esquerda oficial do país. Essa era a orientação do Partido Comunista e também da academia, que já havia institucionalizado as vanguardas trazidas pelo Modernismo nas primeiras décadas do século XX (BRITO, Ronaldo. Neoconcretismo: Vértice e ruptura do projeto construtivo brasileiro. São Paulo: Cosac \& Naify, 1999).
} 
pesquisas dos artistas do Neoconcretismo, que desembocaram na Nova Objetividade Brasileira.

A partir da segunda metade da década de 1960 tornou-se evidente que o abstracionismo deixara de ser a tendência dominante na Arte Contemporânea ${ }^{30}$, tanto no Brasil como em nível internacional. Essa opção dos artistas, identificada como volta à figuração, foi devida à constatação de que, se as questões levantadas pela abstração (principalmente no Concretismo) estavam alinhadas com a expectativa da década anterior, os acontecimentos políticos dos anos de 1960 mudaram drasticamente a situação.

O ano de 1965 significou a tomada de posição política e contestação, pondo fim ao breve silêncio por parte dos artistas desde o golpe de 1964, marcado por prisões arbitrárias, tortura e desaparecimentos. As exposições Opinião 65 (MAM-RJ) e Propostas 65 (MAB-FAAP) e, no ano seguinte, Opinião 66 (MAM-RJ) e Propostas 66 (Biblioteca Municipal - SP) ${ }^{31}$, promoveram mostras de arte, conferências e debates entre artistas e críticos que, tomando a palavra, demarcavam o caminho a ser seguido pela Vanguarda Brasileira até os anos de 1970. Essas exposições tiveram o mérito de proporcionar espaço para conceituações de vários artistas e críticos de arte a respeito das mudanças pelas quais passavam as artes plásticas naquele momento.

O contexto político da época era constituído pela ditadura militar, que após o golpe de 1964 impôs a Mario Schenberg diversas restrições, e pela ameaça da guerra nuclear e a possível extinção da humanidade dela decorrente. Esses foram elementos que influenciaram significativamente a visão de mundo do crítico $^{32}$.

No campo das artes plásticas, os artistas brasileiros sentiram os impasses que envolviam as vertentes nacionais e internacionais. Eles buscavam uma arte mais próxima ao cotidiano, capaz de diálogo direto com o público. Ao mesmo tempo, não queriam renunciar às conquistas das vanguardas. Nessa direção, eles encontravam novos caminhos para responder às demandas da realidade que os cercava. Nesse exercício, aliavam a pop art e o nouveau réalisme ao senso construtivo vindo do concretismo e do

\footnotetext{
${ }^{30}$ SCHENBERG, Mario. Pensando a Arte. São Paulo: Nova Stella, 1988, p. 179.

${ }^{31}$ Apesar de integrarem o contexto, elas não serão objeto de aprofundamento nesta pesquisa.

${ }^{32}$ Em virtude da densidade desse momento artístico e cultural, foi necessário fazer escolhas, trazendo ao percurso expositivo apenas os elementos que motivaram o pensamento e o posicionamento tomado por Mario Schenberg.
} 
neoconcretismo. Esses foram os caminhos que os levaram à nova configuração da vanguarda brasileira ${ }^{33}$.

A reflexão de Schenberg acerca da arte, dos artistas e de seu momento histórico levou em conta elementos que merecem aprofundamento, na medida em que foram relevantes para sua participação no debate estético localizado entre as décadas de 1960 e 1970. Diante disso, este estudo objetivou, principalmente, contribuir para ampliar o conhecimento da contribuição de Mario Schenberg como intelectual e, em especial, como crítico de arte.

A pesquisa investigou e contextualizou a inserção de Mario Schenberg nas bienais de São Paulo nos anos de 1961, 1965, 1967, 1969 e 1971. Evidenciou seu envolvimento nos debates teóricos desse período, levando em conta seu panorama sociopolítico e as tendências por ele percebidas, como o Novo Realismo, a relação entre Arte e Política, a Arte Primitiva, a emergência de novas tecnologias e a Arte Conceitual. Foram analisados os textos produzidos por Schenberg no recorte delimitado, tendo em vista elementos de sua leitura estética, bem como de sua relação com os artistas sobre os quais escreveu, como Alfredo Volpi, Mira Schendel, Waldomiro de Deus, Carmela Gross e Marcelo Nitsche.

Integram o corpo teórico da pesquisa os estudos anteriores sobre o crítico, a saber: Schenberg: crítica e criação, de Alecsandra Matias de Oliveira (São Paulo: Edusp, 2011), que destacou sua trajetória intelectual, apresentando sua visão estética sem perder de vista dados biográficos; e Voar também é com os homens: o pensamento de Mario Schenberg, de José Luiz Goldfarb (São Paulo: Edusp, 1994), que se dedicou ao pensamento científico, artístico e filosófico do crítico. Tais fontes são alicerces notáveis para o desenvolvimento deste estudo. Entretanto, essas obras não tinham por objetivo investigar a atuação de Mario Schenberg nas bienais, mas lançar as bases para estudos posteriores nessa e em diversas outras frentes. O suporte fornecido por esses autores torna possível levar adiante também a investigação de aspectos estéticos de seu pensamento ${ }^{34}$. Acrescenta-se ao quadro teórico a obra de Dina Lida Kinoshita intitulada Mario Schenberg, o cientista e o político (Brasília: Fundação

\footnotetext{
${ }^{33}$ Cf. AJZENBERG, Elza. Exercícios Estéticos da Liberdade. São Paulo: ECA USP, 1989 (tese de livre docência) e GOLDFARB, José Luiz. Voar também é com os Homens. São Paulo: EDUSP, 1994.

${ }^{34}$ Outro estudo importante sobre o crítico intitula-se Obra Científica de Mario Schenberg, de Amélia Império Hamburguer (São Paulo: EDUSP, 2009).
} 
Astrogildo Pereira, 2014), que se dedica à vida política do crítico, uma vez que foi um participante ativo das lutas democráticas no país.

No que diz respeito às bienais de São Paulo, são utilizados os principais estudos realizados até o momento, a saber: MAM-Bienal-MAC: processos de ruptura, de Polyana Canhête Lopes (PGEHA - USP, dissertação de mestrado, São Paulo: 2007); os catálogos das exposições Ciccillo: Acervo MAC-USP - Homenagem a Francisco Matarazzo Sobrinho, Ciccillo (São Paulo, Museu de Arte Contemporânea da Universidade de São Paulo, 2006) e MAC Virtual: Prêmios Bienais Acervo MAC USP (São Paulo: Museu de Arte Contemporânea da Universidade de São Paulo, 2004), ambos com organização de Elza Ajzenberg; Bienais de São Paulo: da era do museu à era dos curadores, de Francisco Alambert e Polyana Lopes Canhête (São Paulo: Boitempo, 2004); a edição número 52 da Revista USP (dez.-fev. 2001-2002), que contém um dossiê sobre a Bienal Internacional de São Paulo e, ainda, o Catálogo Bienal 50 anos: 1951 - 2001 (São Paulo: Fundação Bienal de São Paulo, 2001), que perpassa de modo conciso os primeiros 50 anos do certame. Há, também, o estudo de Leonor Amarante intitulado As Bienais de São Paulo: 1951 a 1987 (São Paulo: Projeto, 1989). Outra fonte significativa é composta pela documentação encontrada no Arquivo Histórico Wanda Svevo, localizado na sede da Fundação Bienal, no qual a investigação busca mais detalhes do envolvimento de Mario Schenberg com as Bienais ${ }^{35}$.

Outros textos da época encontram-se na revista Artes, que estava em circulação entre as décadas de 1950 a 1960 e no periódico Arte em Revista, organizado pelo Centro de Estudos de Arte Contemporânea da FFLCH USP, cujos números do ano de 1979 trazem um dossiê sobre os aspectos culturais da década de $1960^{36}$. É relevante ainda o estudo de Daisy V. M. Peccinini Alvarado chamado Figurações Brasil Anos

\footnotetext{
${ }^{35}$ Outras fontes serão importantes para este estudo, a saber: a biografia de Francisco Matarazzo Sobrinho, intitulada $\mathbf{O}$ franciscano Ciccillo (ALMEIDA, Fernando Azevedo de. São Paulo: Livraria Pioneira, 1976); a autobiografia de Yolanda Penteado Tudo em cor de rosa. (Rio de Janeiro: Nova Fronteira, 1976); MANTOAN, Marcos José. Yolanda Penteado: gestão dedicada à arte moderna. São Paulo, Universidade de São Paulo, Programa de Pós-Graduação em Artes Visuais - Escola de Comunicações e Artes, 2015 (tese de doutorado). No que tange ao contexto político e à ação da ditadura militar na Universidade de São Paulo, foram relevantes os estudos: CLEMENTE, José Eduardo Ferraz: Ciência e política durante a ditadura militar: o caso da comunidade brasileira de físicos (1964-1979). Salvador: Universidade Federal da Bahia, Instituto de Física, 2005 (dissertação de Mestrado) e MOTTA, Rodrigo P. Sá. As universidades e o regime militar: cultura política brasileira e modernização autoritária. $1^{\text {a }}$ edição. Rio de Janeiro: Zahar, 2014.

${ }^{36}$ Esse material foi assinalado em AJZENBERG, Elza. Exercícios Estéticos da Liberdade. São Paulo: ECA USP, 1989 (tese de livre docência).
} 
60: Neofigurações Fantásticas e Neosurrealismo, Novo Realismo e Nova Objetividade (São Paulo: Itaú Cultural/Edusp, 1999).

Também figura como referência a pesquisa realizada em nível de mestrado Schenberg: em busca de um Novo Humanismo (São Paulo: PGEHA/USP, 2013), estudo que objetivou evidenciar a visão de Novo Realismo ${ }^{37}$ de Mario Schenberg, dada sua importância no horizonte das vanguardas brasileiras das décadas de 1960 e 1970, bem como sua relação com o Novo Humanismo, também desenvolvido pelo crítico de arte durante esse período. Nela foi realizado um levantamento inicial acerca da atuação de Mario Schenberg nas bienais de São Paulo, mas foi assinalado que essa frente aberta merecia aprofundamento no futuro. A presente pesquisa se dedica a esse objeto, retomando e ampliando a investigação realizada anteriormente, conforme apontado na conclusão daquele estudo ${ }^{38}$.

A metodologia empregada neste estudo envolve a análise dos textos críticos escritos no período, que contêm reflexões estéticas e propostas dos artistas analisados por Schenberg. Muitos de seus escritos sobre arte foram publicados em catálogos de mostras e no livro Pensando a Arte (São Paulo: Nova Stella, 1988). Foram raras as publicações desse tipo em jornais ou revistas. Uma grande parte de seus textos críticos está depositada nos arquivos do Centro Mario Schenberg de Documentação da Pesquisa em Arte - ECA USP, somando mais de quatrocentos documentos, a maioria ainda inédita. Neles encontram-se textos dedicados a diversos artistas, grupos e movimentos que formaram o cenário das artes plásticas entre as décadas de 1940 a 1980.

A presente investigação toma como fontes primárias - dentre as críticas originais do Centro Mario Schenberg de Documentação da Pesquisa em Arte ECA/USP -, os textos escritos nas décadas de 1960 e 1970, bem como os demais livros, artigos e entrevistas nos quais o crítico expôs seu pensamento. São utilizados, ainda, os relatórios de pesquisas já produzidas pelo Centro Mario Schenberg e estudos em nível

\footnotetext{
${ }^{37}$ Considerada por Mario Schenberg a expressão artística do Novo Humanismo, o Novo Realismo foi definido com base num horizonte paralelo: fruto da sociedade industrial e reflexo da cultura ocidental em crise, essa tendência refletiu um momento de ampliação de referenciais. Schenberg soube compreender as demandas da arte nascente, na medida em que sua atividade crítica não se deu como julgamento e avaliação, mas como compreensão e incentivo.

${ }^{38}$ PISMEL, Ana Paula Cattai. Schenberg: em busca de um Novo Humanismo. São Paulo: Programa de Pós-Graduação Interunidades em Estética e História da Arte, Universidade de São Paulo, 2013 (dissertação de mestrado), p. 163.
} 
de pós-graduação sobre o crítico, além de obras de referência, artigos e outros documentos ${ }^{39}$.

Também foram realizadas pesquisas em outros acervos com a finalidade de levantar fontes documentais que pudessem suprir as lacunas indicadas como problemas de pesquisa. No Arquivo Histórico Wanda Svevo, sediado na Fundação Bienal de São Paulo, realiza-se uma nova busca por documentos relativos às edições da Bienal das quais Mario Schenberg tomou parte, a fim de ampliar o levantamento feito em pesquisa anterior. Além disso, foi feita uma pesquisa no Arquivo Histórico do Instituto de Física da USP, que reúne a documentação referente à atuação científica de Mario Schenberg, com a finalidade de buscar elementos que pudessem complementar os levantamentos documentais já realizados.

O prontuário de Mario Schenberg, que se encontra entre os Arquivos do DEOPS, disponíveis no Arquivo Público do Estado de São Paulo, foi outra fonte de investigação. Num período em que o crítico sofreu com a perseguição política, acreditase que a análise dos documentos de seu prontuário pode revelar detalhes de sua trajetória que ajudem a elucidar aspectos de seu envolvimento no debate estético no período cronológico delimitado.

Infelizmente, muitas das pessoas que conviveram com Schenberg já faleceram. Contudo, foram realizadas algumas entrevistas com artistas, curadores e cientistas a fim de produzir relatos que serviram como fonte primária para esta pesquisa. Isso se deu após os levantamentos bibliográfico e documental, a fim de direcionar o foco das questões a serem colocadas aos entrevistados ${ }^{40}$. Trata-se de entrevistas não-diretivas, de natureza individual e pessoal ${ }^{41}$, ou seja, compostas por questões abertas, para promover maior liberdade para as respostas obtidas ${ }^{42}$. Os relatos foram abordados por meio da análise de conteúdo, com a finalidade de acessar o material qualitativo nelas presente ${ }^{43}$.

\footnotetext{
${ }^{39}$ Para aprofundar esses aspectos, serão importantes também os livros Pensando a Física (São Paulo: Nova Sttela, 1990), Diálogos com Mario Schenberg (São Paulo: Nova Sttela, 1985) e Mario Schenberg: Entre-Vistas (São Paulo: Perspectiva, 1984).

${ }^{40}$ Cabe observar que esse material fará parte dos Arquivos do Centro Mario Schenberg de Documentação da Pesquisa em Arte, constituído por cerca de 400 originais dos textos de crítica de arte datilografados e manuscritos por Mario Schenberg.

${ }^{41}$ GIBBS, G. Análise de dados qualitativos. Porto Alegre: Bookman, 2009.

${ }^{42}$ SEVERINO, Antônio Joaquim. Metodologia do trabalho científico. $23^{\mathrm{a}}$ edição revisada e atualizada. São Paulo: Cortez, 2007, p. 125.

${ }^{43}$ BARDIN, Laurence. Análise de conteúdo. Tradução de Luís Antero Reto, Augusto Pinheiro. Lisboa: Edições 70: 2002, p. 65. As entrevistas foram gravadas com a permissão prévia dos entrevistados, feita por meio de um termo específico.
} 
Foram entrevistados o curador Fábio Magalhães, os artistas José Roberto Aguilar, Maria Bonomi e Caciporé Torres, o físico Sílvio Salinas e a cientista Ana Clara Guerrini Schenberg.

O trabalho se organiza da seguinte forma:

O primeiro capítulo, intitulado "Sala Especial de Alfredo Volpi", traz a contextualização da trajetória da Bienal Internacional de São Paulo até a década de 1960, a fim de situar os elementos necessários para a abordagem do momento em que se dá a aproximação de Mario Schenberg da Bienal. Na segunda parte, examina-se a primeira participação do crítico na organização do certame, a saber, a Sala Especial do pintor Alfredo Volpi na VI Bienal, em 1961.

O segundo capítulo, "Júri de Seleção: em defesa dos artistas", mostra as participações de Schenberg no Júri de Seleção que escolhia as obras que fariam parte da representação brasileira na Bienal. Foram três as atuações do crítico como jurado: na VIII (1965), IX (1967) e X (1969) bienais. Para cada uma delas, foi designada uma parte nesse capítulo.

Em "Mesas e Seminários: o lugar do debate", terceiro e último capítulo desta tese, estão contidas as considerações acerca do momento em que se dá o afastamento de Mario Schenberg dos trabalhos de organização das bienais. São destacadas suas participações em duas mesas redondas da AICA, nos anos de 1969 e 1971, cujo objetivo era discutir possíveis soluções para os problemas enfrentados não apenas pela Bienal de São Paulo, mas por outras grandes exposições internacionais.

Foram incluídas ainda, nos Anexos, fontes relevantes para futuras pesquisas, como documentos e imagens, bem como dados em ordem cronológica. 
Figura 2 - Mario Schenberg, 1940.

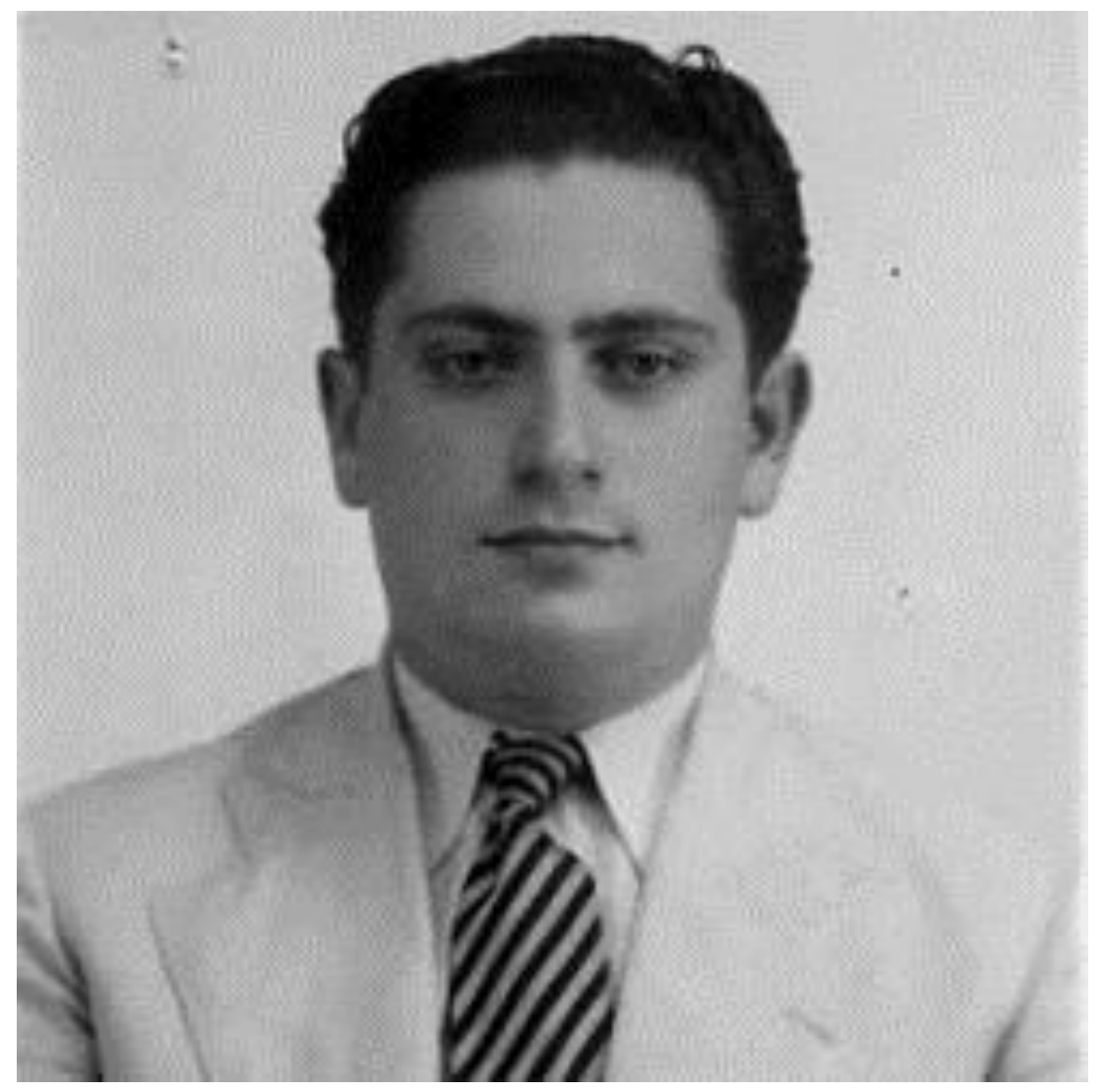

Fonte: JOHN SIMON GUGGENHEIM MEMORIAL FONDATION. Mario

Schenberg - fellow. Disponível em: https://www.gf.org/fellows/allfellows/mario-schenberg/ Acesso em 25/02/2018. 
Figura 3: Mario Schenberg, década de 1960.

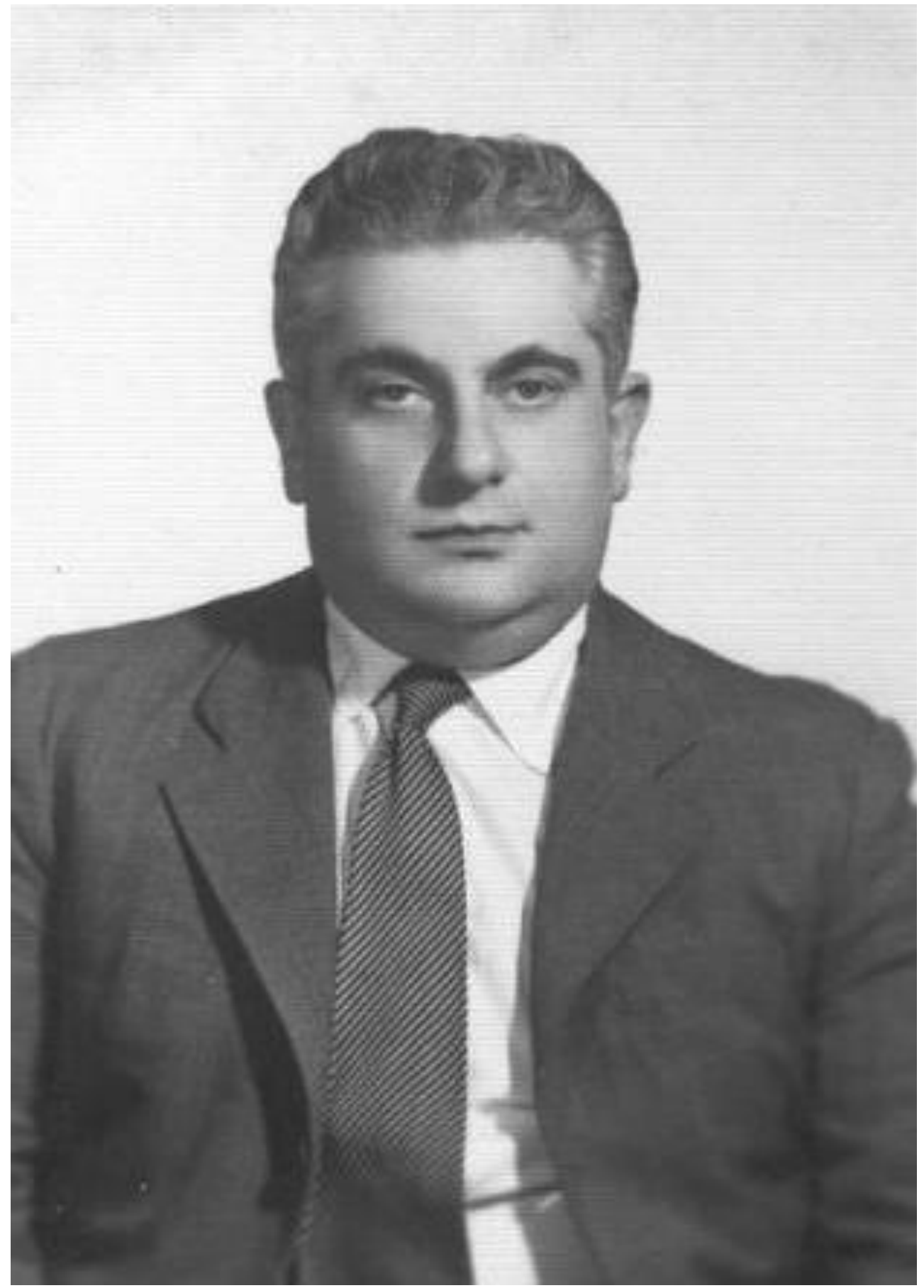

Fonte: Acervo do Centro Mario Schenberg de Documentação da Pesquisa em Artes ECA/USP. 


\section{Sala Especial de Alfredo Volpi}

Homem dos sete instrumentos, Mario Schenberg reunira textos que contemplavam os seus múltiplos interesses: além da biblioteca de física e matemática e uma outra sobre arte, que mantinha ao alcance da mão, ele juntara escritos de filosofia, sociologia, política, literatura e muita coisa sobre história das religiões. Sempre com o mesmo entusiasmo, entretinha-se acerca dos mais variados assuntos; sem jamais desmerecer $o$ que lhe era dito, conversava sobre os temas mais diversos. Era extremamente culto, um exemplo vivo de que a reflexão se nutre da cultura. ${ }^{44}$

Scarlett Marton

\section{As Bienais Internacionais de São Paulo}

A mostra surgiu no cenário cultural, em 1951, momento no qual São Paulo conheceu vertiginoso crescimento. Desde sua primeira edição, sob a denominação de I Bienal do Museu de Arte Moderna de São Paulo, teve a intenção de reunir, a cada dois anos, entre altos e baixos, amostras significativas da produção artística de diversos países do mundo, atraindo elogios e críticas. Nesse sentido, pode-se dizer que a Bienal foi capaz de promover debates que envolviam as artes visuais. Nas palavras de Mário Pedrosa, um dos intelectuais que mais esteve envolvido com a mostra nas décadas de 1950 e 1960, é preciso assumir que "a Bienal de São Paulo veio ampliar os horizontes da arte brasileira", rompendo o "círculo fechado em que se desenrolavam as atividades artísticas do Brasil, tirando-as de um isolacionismo provinciano ${ }^{45}$ ".

Sobre a organização das bienais, a ideia tem sido atribuída ao mecenas, Francisco Matarazzo Sobrinho, mais conhecido como Ciccillo, empresário de origem

\footnotetext{
${ }^{44}$ MARTON, Scarlett. A irrecusável busca de sentido: autobiografia intelectual. Cotia, SP: Ateliê Editorial; Ijuí, RS: Edirora UNIJUÍ, 2004, p. 155.

${ }^{45}$ PEDROSA, Mário. A Bienal de cá para lá. In: ARANTES, Otília (org.) Política das Artes. São Paulo: EDUSP, 1995, p. 221. Para um estudo aprofundado acerca do contexto cultural que forneceu antecedentes para o surgimento das Bienais, ver ALAMBERT, Alambert; CANHÊTE, Polyana. Bienais de São Paulo: da era do museu à era dos curadores. São Paulo: Boitempo, 2004.
} 
italiana. ${ }^{46}$ Yolanda Penteado, que era então sua esposa, registrou que a proposta teria surgido de modo imprevisto:

Um dia, o Ciccillo estava conversando com o Arturo Porfili, e me fez essa pergunta:

- Você não quer experimentar fazer uma Bienal?

Fiquei muito espantada porque nem sabia direito o que era uma bienal. Aí me disseram:

- Já escrevemos a diversos países, sugerindo essa ideia, mas não veio resposta. Você não quer tentar? ${ }^{47}$

Já o crítico argentino Romero Brest tinha suas dúvidas quanto a Ciccillo, achando mais plausível creditar à própria Yolanda tal ideia. ${ }^{48} \mathrm{O}$ artista Danilo Di Prete, por sua vez, afirmou que teria sido ele a sugerir, mais ou menos em 1946, que se fizessem bienais no Brasil. ${ }^{49}$ De qualquer modo, quando Ciccillo expôs a ideia de que se organizasse uma bienal, nos moldes da Bienal de Veneza $^{50}$, levada a cabo pelo Museu de Arte Moderna, criado não muito tempo antes, em 1948 ${ }^{51}$, o crítico Paulo Mendes de Almeida deixou clara sua ressalva quanto à ousadia da ideia:

46 Francisco Matarazzo Sobrinho (São Paulo SP 1898-1977). Era sobrinho do Conde Francisco Matarazzo, italiano que construiu um dos maiores complexos industriais do Brasil. Estudou no Instituto de Educação Caetano de Campos, na Praça República. Em 1908, seguiu para Nápoles, acompanhado de um preceptor, a fim de completar o ensino médio. Depois, em Liège (Bélgica), cursou engenharia. Ele viveu na Europa entre os 10 e os 20 anos, recebendo formação humanística da Belle Époque. Ciccillo comandou parte do conglomerado de indústrias metalúrgicas da família. Com o desmembramento das empresas, na década de 1930, tornou-se o único proprietário da Metalúrgica Matarazzo-Metalma. ALMEIDA, F. A. O franciscano Ciccillo. São Paulo: Pioneira, 1976, p. 20.

${ }^{47}$ PENTEADO, Yolanda. Tudo em cor de rosa. Rio de Janeiro: Nova Fronteira, 1976, p. 178.

${ }^{48}$ AMARANTE, Leonor. As Bienais de São Paulo: 1951 a 1987. São Paulo: Projeto, 1989, p. 13.

${ }^{49}$ Sobre isso, ver ROCCO, Renata Dias Ferrareto. Danilo Di Prete no Brasil: sobre relatos de vida, a criação da Bienal de São Paulo e o arquivo da família. In: FREIRE, Cristina (org.). Escrita da história e (re)construção das memórias: arte e arquivos em debate. Congresso Internacional de Estética e História da Arte. São Paulo: MAC USP, 2016, p.335 - 340.

${ }^{50}$ A primeira Bienal de Veneza foi organizada por um grupo de intelectuais, liderados pelo prefeito da época, Riccardo Selvatico, e inaugurada em 30 de abril de 1895. A mostra foi pensada para incluir artistas italianos (por convite direto ou por seleção de um júri) e artistas estrangeiros. Ao longo da história, os países estrangeiros construíram cada um seu próprio pavilhão. Entre 1916 e 1918, a Bienal foi cancelada por causa da I Guerra Mundial. Em 1930, a Bienal de Veneza ganhou autonomia e, no ano seguinte, teve seu estatuto e suas formas de financiamento instituídas por decreto. Surgiram novos eventos (música, cinema e teatro) e a Bienal assumiu o caráter multidisciplinar atual. Após o início das hostilidades durante a II Guerra Mundial, a Bienal foi interrompida em 1942. A Exposição de Arte foi retomada em 1948. Após a guerra e a queda do fascismo, a Exposição Internacional de Arte reapareceu, sob a chefia de Rodolfo Pallucchin, secretário-geral e historiador de arte. Sob seu comando, entre 1948 e 1954, a Bienal se tornou um observatório da arte contemporânea e das tendências de vanguarda. Cf. LA BIENNALE DI VENEZIA. History. Disponível em <http://www.labiennale.org/en/history/>. Acesso em 21 fev. 2018.

${ }^{51}$ A primeira sede do Museu de Arte Moderna foi instalada em uma sala do edifício dos Diários Associados, na Rua Sete de Abril, abrigando também o Sindicato dos Artistas Plásticos e Musicais de São Paulo - lugar cedido por Assis Chateaubriand. O projeto arquitetônico da sala do MAM foi assinado por Vilanova Artigas e dispunha de salas de exposição, bar, biblioteca e local para projeção de filmes. 
Eu era então o diretor artístico do Museu de Arte Moderna de São Paulo e não quero esconder que, ao lançar Francisco Matarazzo Sobrinho a idéia de levar o museu a realizar uma Bienal, fui dos mais acirrados opositores. Realmente, o Museu começava. Não ouso recorrer à consagrada expressão "mal começava", porque começava muito bem. [...] Fazer a Bienal era, em verdade, arriscar a bela e positiva experiência do Museu, atirando-a a um plano desconhecido, em que poderia ter êxito ou não ${ }^{52^{\prime \prime}}$ (grafia original).

Em 1948, Ciccillo visitou pela primeira vez a Bienal de Veneza e, dois anos depois, levou ao evento a primeira representação brasileira ${ }^{53}$, composta pelos artistas Lívio Abramo, Victor Brecheret, Roberto Burle Marx, Milton Dacosta, Flávio de Carvalho, Cícero Dias, Emiliano Di Cavalcanti, Bruno Giorgi, Oswaldo Goeldi, José Pancetti, Cândido Portinari e Alfredo Volpi ${ }^{54}$. De lá, o industrial trouxe uma cópia do regulamento das bienais italianas, que foi adaptado à realidade brasileira com a ajuda de Lourival Gomes Machado, então diretor artístico do MAM ${ }^{55}$.

Mas qual seria a motivação de Ciccillo para realizar um projeto do porte das bienais? Polyana Canhête Lopes assinala que o grande crescimento da mostra, ano a ano, bem como os interesses comerciais que um evento desse porte envolvia, teriam sido uma das razões pelas quais Ciccillo levaria adiante o projeto das bienais internacionais $^{56}$. Para Leonor Amarante, a iniciativa estaria no plano do jogo de poder e vaidade. Com isso, "numa só tacada ele atingiu a antão Capital Federal, Rio de Janeiro, que mantinha a fama de ser o centro cultural do Brasil, e o rival Chateaubriand. Este último criou, em 1947 o Museu de Arte de São Paulo"57. Na visão do historiador José Carlos Durand, contudo, as motivações de Ciccillo teriam sido outras: muito

\footnotetext{
52 ALMEIDA, Paulo Mendes de. De Anita ao Museu. São Paulo: Perspectiva, 1976, p. 221.

${ }^{53}$ LOPES, Polyana Canhête. MAM-Bienal-MAC: processos de ruptura. São Paulo: Universidade de São Paulo, Programa Interunidades de Pós-Graduação em Estética e História da Arte, 2007. (dissertação de mestrado).

54 25. Esposizione Biennale Internazionale d'Arte, Archivo Storico Delle Arti Contemporanee/La Biennale di Venezia. Disponível em: <http://asac.labiennale.org/it/passpres/artivisive/annali.php?m=228\&s=4580\&c=ea>. Acesso em $21 \mathrm{fev}$. 2018.

55 AMARANTE, Leonor. As Bienais de São Paulo: 1951 a 1987. São Paulo: Projeto, 1989.

${ }^{56}$ LOPES, Polyana Canhête. MAM-Bienal-MAC: processos de ruptura. São Paulo: Universidade de São Paulo, Programa Interunidades de Pós-Graduação em Estética e História da Arte, 2007. (dissertação de mestrado).

${ }^{57}$ AMARANTE, Leonor. As Bienais de São Paulo: 1951 a 1987. São Paulo: Projeto, 1989, p. 14.
} 
provavelmente, teria sido a vontade de obter destaque dentro de sua própria família, entre seus irmãos, sendo que a rivalidade com Chateaubriand teria espaço secundário ${ }^{58}$.

Já a artista Maria Bonomi (2018) ${ }^{59}$, que conviveu com Ciccillo nesse período, relata que sua família não aprovada seus vultuosos gastos com as bienais. Em seu entender, o empresário não agia apenas por conta de sua visão estratégica em relação aos negócios, mas sobretudo com base na percepção de que, por meio do evento, seria possível promover um espaço internacional de debate artístico e cultural, que sem dúvida atrairia atenção para a São Paulo que crescia mais a cada dia.

Nesse sentido, o projeto das bienais internacionais de São Paulo tinha por finalidade atualizar a inteligência do país em relação à arte, assim como foi o propósito da Semana de 1922. Sobre isso, Mário de Andrade ${ }^{60}$ escreveu: “o que caracteriza essa realidade que o movimento modernista impôs é, a meu ver, a fusão de três princípios fundamentais: o direito permanente à pesquisa estética; a atualização da inteligência artística do país; e a estabilização de uma consciência criadora nacional". Pode-se dizer que a proposição do autor de Macunaíma reverberou além do contexto do modernismo, fazendo-se presente também nas Vanguardas Brasileiras das décadas de 1950 e 1960, bem como nas bienais, dado que também visaram a atualização da inteligência e o debate no campo das artes.

Assim, em 20 de outubro de 1951, foi inaugurada a I Bienal do Museu de Arte Moderna de São Paulo, caracterizada por Leonor Amarante como "a mais ousada manifestação cultural já sonhada nos trópicos". ${ }^{61}$ A exposição trazia 1.800 obras, provenientes de 20 países, com o predomínio de tendências abstratas. O local não merecia menos destaque: tratava-se do antigo Trianon, local elegante situado na Avenida Paulista, frequentado pela alta sociedade da época. Para a I Bienal, o pavilhão foi reformado e adaptado pelos arquitetos Luís Saia e Eduardo Kneese de Mello ${ }^{62}$. Organizada pelo MAM, estavam à frente da mostra Lourival Gomes Machado, Carlos

\footnotetext{
${ }^{58}$ DURAND, José Carlos. Arte, Privilégio e Distinção: artes plásticas, arquitetura e classe dirigente no Brasil (1855 - 1985). São Paulo: Perspectiva, 1989.

${ }^{59}$ BONOMI, Maria. Entrevista concedida a Ana Paula Cattai Pismel. São Paulo, 16 mai. 2018. 4 arquivos .mp3 (1h46'15"). [A entrevista encontra-se depositada no Centro Mario Schenberg de Documentação da Pesquisa em Arte - ECA/USP]

${ }^{60}$ ANDRADE, Mário de. O Movimento Modernista. In: Aspectos da Literatura brasileira. $6^{\mathrm{a}}$ ed. Belo Horizonte: Itatiaia, 2002, p. 266.

${ }^{61}$ AMARANTE, Leonor. As Bienais de São Paulo: 1951 a 1987. São Paulo: Projeto, 1989, p. 12.

${ }^{62}$ ALAMBERT, Francisco e LOPES, Polyana Canhête. As Bienais de São Paulo: da Era dos Museus à Era dos Curadores (1951- 2001), São Paulo: Boitempo, 2004.
} 
Figura 4 - Vista geral da $1^{\text {a }}$ Bienal (1951)

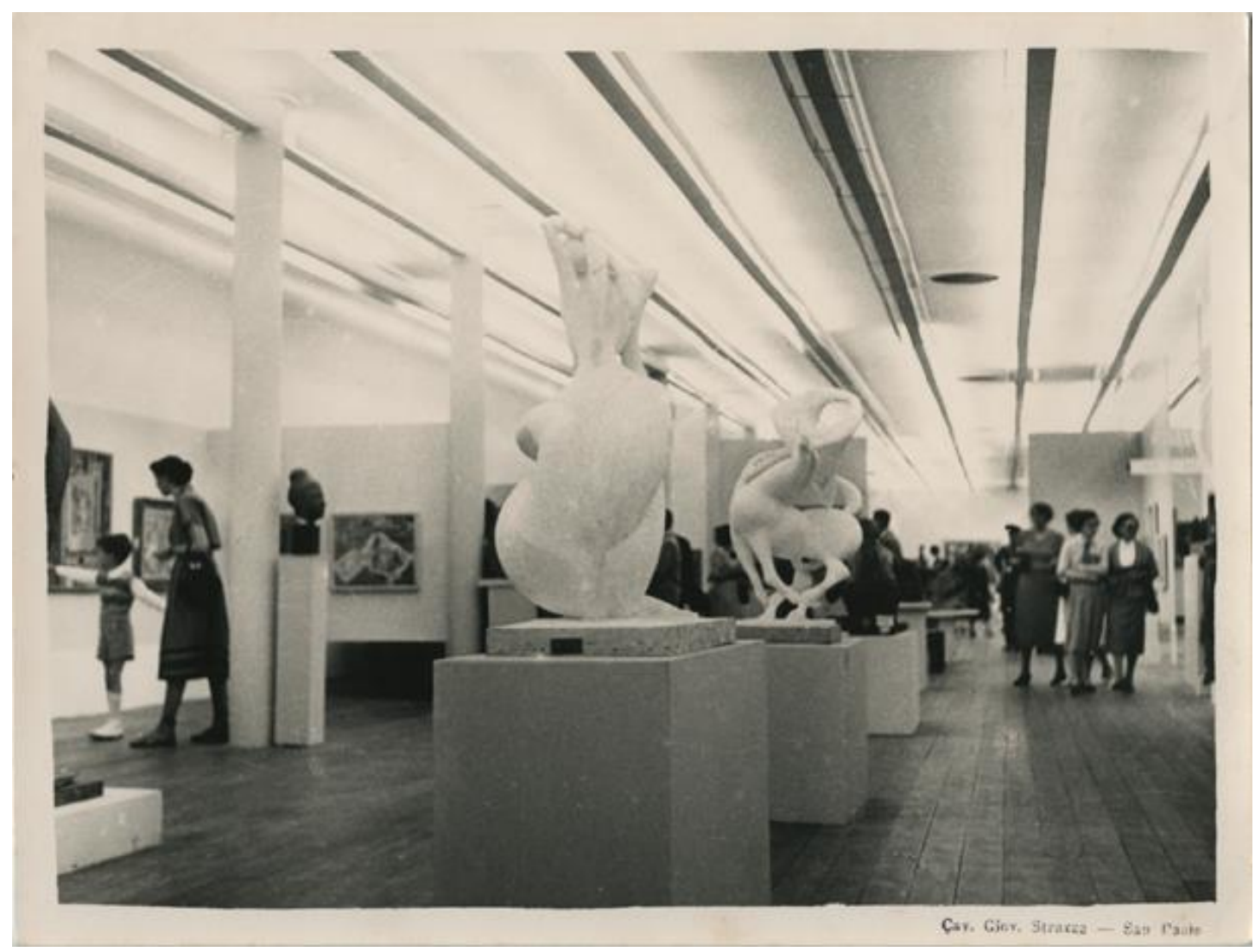

Fonte: FUNDAÇÃO BIENAL DE SÃO PAULO. As bienais e seus pavilhões. Disponível em: <http://www.bienal.org.br/post/404> Acesso em 10/ jun. 2018.

Pinto Alves e Sérgio Milliet. A I Bienal apresentava ao público de um país em que praticamente não havia museus, propostas das vanguardas internacionais, tais como os trabalhos de: Pablo Picasso, Fernand Léger, Max Bill, Alexander Calder, Giorgio Morandi e Alberti Giacometti. Na seleção brasileira, estavam representados Emiliano Di Cavalcanti, Cândido Portinari, Lasar Segall, Victor Brecheret e Bruno Giorgi ${ }^{63}$.

Apesar de organizada às pressas e entre diversas incertezas, a I Bienal do Museu de Arte Moderna foi bem sucedida. Evidentemente, surgiram elogios e críticas - fato que acompanharia toda a trajetória das bienais. Na imprensa, falassem bem ou mal, todos falavam da Bienal: de um lado, havia questionamentos a respeito de diversos aspectos da mostra (a direção de Ciccillo, os critérios de seleção dos artistas e das premiações, e mesmo os artistas e as obras presentes); de outro, havia a divulgação detalhada das presenças ilustres, das menções dignas de colunas sociais e de dossiês a

${ }^{63}$ AMARANTE, Leonor. As Bienais de São Paulo: 1951 a 1987. São Paulo: Projeto, 1989. 
respeito da I Bienal ${ }^{64}$. Cabe destacar o impacto do evento no meio artístico, com a premiação da escultura Unidade Tripartida de Max Bill e da tela Formas de Ivan Serpa, que sinalizaram a emergência das tendências construtivas na arte, cujos desdobramentos chegaram ao Concretismo e ao Neoconcretismo.

Novamente, em 1953, 1955, 1957 e 1959, as edições das bienais seguiriam movimentando o cenário cultural do país. As exposições foram muito elogiadas, de modo geral, durante toda a década de $1950^{65}$. Entre os anos de 1961 e 1966, a Bienal iniciou o processo de desvinculação do MAM, passando o evento a ser organizado pela Fundação Bienal, que obteria recursos municipais e estaduais para financiar suas atividades, mas continuaria sob o comando de Ciccillo ${ }^{66}$. Francisco Alambert e Polyana Canhête observam que:

(...) a Bienal nunca existiu sem grandes polêmicas, que vão do campo artístico (o debate entre figurativismo e abstracionismo; o papel do crítico e do curador; a diversificação de meios e de suportes; as acusações à direita, de ser um evento "imoral", ou à esquerda, de ser um evento "burguês e alienado") ao organizativo (a relação com o MAM-SP, a figura de Ciccillo, a constituição sempre polêmica de sua Fundação, o debate sobre a participação do Estado e das verbas públicas e privadas, a relação com o "público" ou com a "massa") ${ }^{67}$.

Mário Pedrosa, que atuou como diretor do Museu de Arte Moderna até sua dissolução, inicialmente estava de acordo com a desvinculação entre o museu e a bienal, chegando a escrever um anteprojeto, no qual estava prevista a criação de uma fundação sem fins lucrativos, que administraria a verba destinada à bienal. O MAM, contudo, continuaria desenvolvendo suas atividades e organizando as bienais, mas contaria com um orçamento próprio ${ }^{68}$. Sobre isso, Pedrosa relatou que havia uma vulnerabilidade muito grande do orçamento do museu e a bienal, que até 1960 era um evento do museu. As subvenções recebidas já eram poucas e, mesmo assim, já vinham destinadas à bienal. Com isso, o museu ficava sem espaço no montante que geria, embora necessitasse de

\footnotetext{
${ }^{64}$ ALAMBERT, Francisco e LOPES, Polyana Canhête. As Bienais de São Paulo: da Era dos Museus à Era dos Curadores (1951- 2001), São Paulo: Boitempo, 2004.

${ }^{65}$ ALAMBERT, Francisco e LOPES, Polyana Canhête. As Bienais de São Paulo: da Era dos Museus à Era dos Curadores (1951- 2001), São Paulo: Boitempo, 2004.

${ }^{66}$ ALAMBERT, Francisco e LOPES, Polyana Canhête. As Bienais de São Paulo: da Era dos Museus à Era dos Curadores (1951- 2001), São Paulo: Boitempo, 2004.

${ }^{67}$ ALAMBERT, Francisco e LOPES, Polyana Canhête. As Bienais de São Paulo: da Era dos Museus à Era dos Curadores (1951- 2001), São Paulo: Boitempo, 2004, p. 16.

${ }^{68}$ ALAMBERT, Francisco e LOPES, Polyana Canhête. As Bienais de São Paulo: da Era dos Museus à Era dos Curadores (1951- 2001), São Paulo: Boitempo, 2004.
} 
muito menos dinheiro que a mostra para sobreviver ${ }^{69}$. As bienais só fizeram agravar o problema, ao passo que usavam a maior parte dos recursos humanos e materiais do museu na organização das bienais. Para Mário Pedrosa, “a bienal, criatura do museu, sufocou seu criador" 70 .

Como as bienais cresciam a cada edição, demandando mais e mais recursos financeiros, no início da década de 1960, mesmo um mecenas como Ciccilo Matarazzo não tinha mais como arcar com os eventos sozinho. De qualquer modo, a dependência de uma única fonte de financiamento fez com que o MAM ficasse exposto ao que se deu em 1963: sua dissolução, realizada por Ciccillo Matarazzo. Posteriormente, houve a doação do acervo do MAM à Universidade de São Paulo (que depois criou o Museu de Arte Contemporânea), juntamente com sua coleção pessoal e a de Yolanda Penteado $^{71}$.

Contudo, alguns meses depois de receber o ante-projeto, Ciccillo Matarazzo o colocou em prática, mas com modificações. Em vez de apenas separar as verbas da bienal e do museu, o empresário configurou a fundação sem fins lucrativos que viria a organizar ela mesma a bienal, e optou por desfazendo-se do $\mathrm{MAM}^{72}$. Teve início, então, a procura por um mecenas substituto. Essa busca durou meses e não encontrou nenhuma pessoa ou empresa interessada em financiar o MAM. É nesse contexto que Ciccillo convoca uma reunião extraordinária dos sócios em janeiro de 1963, para os quais explica que não há substituto. Não podendo se responsabilizar pelas duas instituições, o empresário dissolveu a sociedade civil $^{73}$.

Embora tenha transcorrido entre críticas e aplausos desde sua primeira edição, a Bienal, que teve avaliação assertiva na década de 1950, passou, na década seguinte, por uma profunda crise. Nos anos de 1960, malgrado o surgimento de novas tendências artísticas, que criavam sobre diversos suportes e pesquisavam toda sorte de técnicas, materiais e tecnologias, a Bienal não tinha realizado adaptações em sua configuração

\footnotetext{
${ }^{69}$ PEDROSA, Mário. Depoimento sobre o MAM. In: ARANTES, Otília (Org.). Mário Pedrosa/política das artes. São Paulo: Edusp, 1995. p. 299-308.

${ }^{70}$ PEDROSA, Mário. Depoimento sobre o MAM. In: ARANTES, Otília (Org.). Mário Pedrosa/política das artes. São Paulo: Edusp, 1995. p. 299-308, p. 303.

${ }^{71}$ PEDROSA, Mário. Depoimento sobre o MAM. In: ARANTES, Otília (Org.). Mário Pedrosa/política das artes. São Paulo: Edusp, 1995. p. 299-308.

${ }^{72}$ PEDROSA, Mário. Depoimento sobre o MAM. In: ARANTES, Otília (Org.). Mário Pedrosa/política das artes. São Paulo: Edusp, 1995. p. 299-308.

${ }^{73}$ ALAMBERT, Francisco e LOPES, Polyana Canhête. As Bienais de São Paulo: da Era dos Museus à Era dos Curadores (1951- 2001), São Paulo: Boitempo, 2004.
} 
para dar conta dessas demandas. Já avistando sua décima edição, a organização da mostra permanecia do mesmo modo que nas primeiras edições. Por isso, no meio artístico, havia o desejo de que fossem realizadas melhorias nas exposições ${ }^{74}$.

Além disso, estava em andamento um processo de profissionalização da crítica de arte como setor especializado - o que proporcionava marcação de posições mais sistemáticas e realização de demandas incisivas para a disposição da mostra, bem como a reivindicação de participação em sua organização. Em 1948, foi criada, na França, a Associação Internacional de Críticos de Arte (AICA), órgão ligado à UNESCO. No ano seguinte, seria criada sua seção nacional, a Associação Brasileira de Críticos de Arte (ABCA). Na fundação da seção brasileira, estavam, entre outros, os críticos Sérgio Milliet (que foi seu primeiro presidente), além de Mário Barata, Antonio Bento e Mário Pedrosa $^{75}$.

Com relação ao contexto artístico, cabe fazer uma breve contextualização, começando pelo surgimento do movimento Concretista, que se deu na década de 1950, catalisado pelo impacto do intercâmbio das primeiras Bienais de Arte de São Paulo, nas quais figuraram obras como Unidade Tripartida de Max Bill. Para Schenberg, essa tendência foi ao encontro da realidade brasileira que, naquele momento, estava permeada pelo otimismo desenvolvimentista e pela intensificação do processo de industrialização de São Paulo que, assim como o Rio de Janeiro, começou a tomar ares de metrópole. ${ }^{76}$

Em 1952 aconteceu a exposição do Grupo Ruptura, em São Paulo, que marcou o início do Concretismo no Brasil. Anatol Wladislaw, Lothar Charoux, Féjer, Geraldo de Barros, Leopold Haar e Luiz Sacilotto, com liderança de Waldemar Cordeiro são os nomes que figuraram no grupo. No ano seguinte, Maurício Nogueira Lima se integrou ao grupo, cuja proposta, baseada no legado do abstracionismo geométrico e do

\footnotetext{
${ }^{74}$ ALAMBERT, Francisco e LOPES, Polyana Canhête. As Bienais de São Paulo: da Era dos Museus à Era dos Curadores (1951- 2001), São Paulo: Boitempo, 2004.

75 ASSOCIAÇÂO BRASILEIRA DE CRİTICOS DE ARTE. Histórico. Disponível em: <http://abca.art.br/historico/>Acesso em 23. fev. 2018.

${ }^{76}$ CONCRETISMO. In: ENCICLOPÉDIA Itaú Cultural de Arte e Cultura Brasileiras. São Paulo: Itaú Cultural, 2018. Disponível em: <http://enciclopedia.itaucultural.org.br/termo370/concretismo〉. Acesso em: 10 de Jun. 2018. Mario Schenberg observou que "houve durante a década dos cinquenta uma tendência generalizada para o construtivismo, contrastando nitidamente com a tendência para $o$ expressionismo, característica da década dos quarenta. Os movimentos concretista e neoconcretista podem mesmo ser vistos como frutos daquela tendência, provavelmente relacionada com o clima desenvolvimentista daqueles anos de otimismo e despreocupação." SCHENBERG, Mário. "Concretismo e neoconcretismo", in Pensando a arte. São Paulo: Nova Stella, 1988, p. 216.
} 
construtivismo, defendia uma arte ligada às pesquisas estéticas de ordem formal, além de um fazer artístico próximo ao trabalho industrial e fortemente ligado à racionalidade ${ }^{77}$.

No Rio de Janeiro surgiu, em 1954, o Grupo Frente, fundado por Aluísio Galvão, Carlos Val, Décio Vieira, Ivan Serpa, João José da Silva Costa, Lygia Clark, Lígia Pape e Vicent Ibberson, aos quais se juntam ainda Hélio e César Oiticica, Elisa Martins da Silveira, Emil Baruch, Frans Weissemann, Abrahan Palatnik e Ruben Ludolf. Como críticos e teóricos: Mário Pedrosa e Ferreira Gullar.

Mais abertos que o grupo paulista, os concretistas cariocas propunham pesquisas em diversas linguagens, não restringindo sua atenção ao abstracionismo geométrico. Afastando-se da "consideração da obra como 'maquina' ou 'objeto"”, contrariamente aos paulistas, os cariocas defendiam "maior ênfase na intuição como requesito fundamental do trabalho artístico"78. Explicitadas na Exposição Nacional de Arte Concreta (São Paulo, 1956), essas divergências levaram à ruptura neoconcreta em 1959, com a publicação do Manifesto Neoconcreto ${ }^{79}$.

Na segunda metade da década de 1950, o otimismo proveniente do plano de desenvolvimento do governo de Juscelino Kubitschek e da relativa estabilidade política do período configurou um terreno propício para a arte concreta, fortemente pautada pela racionalidade e pela proximidade com a tecnologia ${ }^{80}$. Já a década de 1960 viu a mudança

${ }^{77}$ CONCRETISMO. In: ENCICLOPÉDIA Itaú Cultural de Arte e Cultura Brasileiras. São Paulo: Itaú Cultural, 2018. Disponível em: <http://enciclopedia.itaucultural.org.br/termo370/concretismo〉. Acesso em: 10 de Jun. 2018. ${ }^{78}$ CONCRETISMO. In: ENCICLOPÉDIA Itaú Cultural de Arte e Cultura Brasileiras. São Paulo: Itaú Cultural, 2018. Disponível em: <http://enciclopedia.itaucultural.org.br/termo370/concretismo〉. Acesso em: 10 de Jun. 2018.

${ }^{79}$ Mario Schenberg apontou que a diferença entre o ambiente de atuação dos concretistas de São Paulo (industrializada) e do Rio de Janeiro (capital política e administrativa do país) estava ligada à divergência de interesses entre os dois grupos. Os concretistas paulistas estavam interessados na industrialização e seu grupo "tornou-se mais fechado, em consequência da liderança autoritária de Waldemar Cordeiro e da sua "ortodoxia doutrinária" (SCHENBERG, Mario. Pensando a arte, 1988, p. 216). Já os cariocas, nos desdobramentos neoconcretos, teriam sido capazes de "atrair melhor as tendências construtivistas generalizadas, graças à maior flexibilidade das concepções de personalidades como Mário Pedrosa, Lygia Clark, Ferreira Gullar, Frans Weissemann e Amílcar de Castro" (SCHENBERG, Mario. Pensando a arte, 1988, p. 216.).

${ }^{80}$ A arte concreta representou, até os anos de 1960, a principal alternativa à forte presença do realismo oficial, regionalista, propagado pela esquerda oficial do país. Essa era a orientação do Partido Comunista e também da academia, que já havia institucionalizado as vanguardas trazidas pelo Modernismo nas primeiras décadas do século XX (BRITO, Ronaldo. Neoconcretismo: Vértice e ruptura do projeto construtivo brasileiro. São Paulo: Cosac \& Naify, 1999). 
de expectativa decorrente do regime militar, um dos motivos do teor de contestação que a arte do período veio a ter.

Após o debate abstração versus figuração, que marcou a tensão entre a arte concreta e o realismo regionalista social pregado pelo Partido Comunista nos anos de 1950, a década seguinte presenciou o enfraquecimento do abstracionismo geométrico e do expressionismo abstrato (até então, uma vedete internacional) em nome de desdobramentos mais próximos da Pop Art e do Nouveau Réalisme europeu, além das pesquisas dos artistas do Neoconcretismo, que desembocaram na Nova Objetividade Brasileira.

A partir da segunda metade da década de 1960 tornou-se evidente a constatação de que "o abstracionismo já deixou de ser a tendência dominante na Arte Contemporânea" 81 , tanto no Brasil, como em nível internacional. Essa opção dos artistas, identificada como volta à figuração, foi devida à constatação de que, se as questões levantadas pela abstração (principalmente no Concretismo) estavam alinhadas com a expectativa da década anterior, os acontecimentos políticos dos anos de 1960 mudaram drasticamente essa situação.

O abandono da abstração estava envolvido nesse debate ideológico. O expressionismo abstrato, "que não tinha temas observáveis ou pontos de referência palpáveis, pôde se espalhar como uma pandemia cultural em todo o mundo, assumindo o 'dialeto' local onde quer que aparecesse" ${ }^{\text {" }}$; e foi incentivado pelo governo dos Estados Unidos, cujo plano cultural fazia parte da polaridade em relação ao figurativismo da União Soviética. Ao lado desse fato, estava sua consolidação hegemônica diante da América Latina, estancada por regimes totalitários, e da Europa, enfraquecida em decorrência das Guerras Mundiais. Nesse contexto em que o centro do universo artístico tinha sido deslocado de Paris a Nova York, o expressionismo abstrato foi ao encontro do anseio de consolidação de uma hegemonia cultural, não apenas em relação ao mercado de arte, mas também a uma posição de vanguarda quanto à produção de seus $\operatorname{artistas}^{83}$.

A política intervencionista dos Estados Unidos era vista com incômodo pelos artistas brasileiros e latino-americanos, que viviam sob regimes totalitários, constituindo

\footnotetext{
${ }^{81}$ SCHENBERG, Mario. Pensando a Arte, São Paulo: Nova Stella, 1988, p179.

${ }^{82}$ WARHOL, Andy. Catálogo de exposição. Andy Warhol: Mr. América. Catálogo de exposição. São Paulo: Pinacoteca do Estado, 2010, p 11).

${ }^{83}$ WARHOL, Andy. Catálogo de exposição. Andy Warhol: Mr. América. Catálogo de exposição. São Paulo: Pinacoteca do Estado, 2010.
} 
um dos motivos que levou o expressionismo abstrato ao abandono. A liberação da abstração representava a tomada de posição em relação ao estado de coisas vigente no país e na América Latina ${ }^{84}$.

A necessidade de posicionamento e de denúncia da realidade pós-64 passou a ter muito peso na postura dos artistas da vanguarda brasileira. Sobre isso, Ferreira Gullar ${ }^{85}$, no texto Opinião 65, discorrendo sobre a exposição que empresta o nome ao artigo, afirmou que o abandono da abstração não foi imediato, nem isento de entraves e recuos.

Não se tratou, é claro, de afirmar categoricamente o desaparecimento do abstracionismo. Mas a constatação generalizada por parte da crítica e dos artistas foi de que essa vertente, como linha de condução de toda uma ambientação do cenário artístico que vigorou até o fim da década de 1950, já não apresentava mais caminhos a avançar em termos de experimentação e de novas possibilidades, pois não se mostrava como repertório adequado à intenção e às novas demandas sentidas pelos artistas naquele contexto histórico conturbado.

O ano de 1965 significou a tomada de posição política e contestação, pondo fim ao breve silêncio por parte dos artistas desde o golpe de 1964, marcado por prisões arbitrárias, tortura e desaparecimentos. As exposições Opinião 65 (MAM-RJ) e Propostas 65 (MAB-FAAP) - e, no ano seguinte, Opinião 66 (MAM-RJ) e Propostas 66 (Biblioteca Municipal - SP) - promoveram mostras de arte, conferências e debates entre artistas e críticos que, tomando a palavra, demarcavam o caminho a ser seguido pela Vanguarda Brasileira até os anos de 1970. Essas exposições tiveram o mérito de proporcionar espaço para conceituações de vários artistas e críticos de arte a respeito das mudanças pelas quais passavam as artes plásticas naquele momento ${ }^{86}$.

\footnotetext{
${ }^{84}$ WARHOL, Andy. Catálogo de exposição. Andy Warhol: Mr. América. Catálogo de exposição. São Paulo: Pinacoteca do Estado, 2010.

${ }^{85}$ GULLAR, Ferreira. Opinião 65 (Revista Civilização Brasileira). In Arte em Revista (nº 2), São Paulo, CEAC, Maio-Agosto, 1979.

${ }^{86}$ Opinião 65 teve lugar no Museu de Arte Moderna do Rio de Janeiro, entre agosto e setembro de 1965. Foi organizada por Jean Boghici e Ceres Franco. A proposta da exposição era reunir artistas residentes em Paris e no Brasil, promovendo um confronto entre a produção daqueles e a dos jovens artistas de vanguarda no país. Ambos tinham proximidade a nova figuração, a Pop Art e o Nouveau Réalisme. Pouco tempo depois, em São Paulo, foi inaugurada a exposição Propostas 65, no Museu de Arte Brasileira da Fundação Armando Álvares Penteado (MAB/FAAP), em dezembro, acompanhada de um seminário. A mostra paulista foi a repercussão imediata de a exposição carioca e, reunindo muitos dos artistas participantes de Opinião 65. No ano seguinte, Opinião 66, também no MAM do Rio, abria entre agosto e setembro de 1966, por iniciativa dos mesmos organizadores. Em dezembro do mesmo ano, teve lugar o seminário Propostas 66, dessa vez na Biblioteca Pública Municipal Mário de Andrade.
} 
Figura 5- Pavilhão localizado na Esplanada do Trianon, na Avenida Paulista. Autor não identificado.

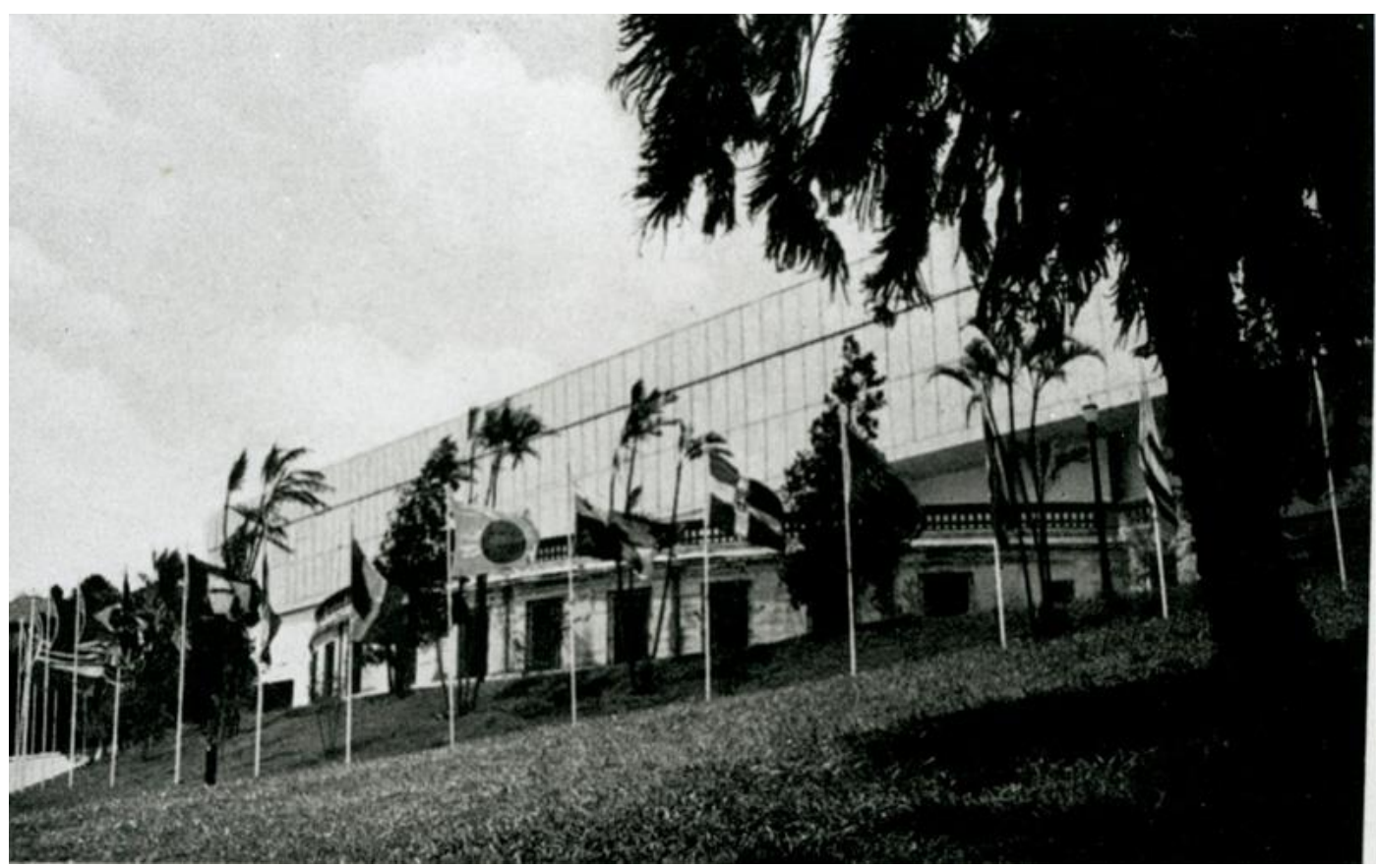

Fonte: FUNDAÇÃO BIENAL DE SÃO PAULO. $1^{\mathbf{a}}$ Bienal de São Paulo. Disponível em: <http://www.bienal.org.br/exposicoes/1bienal/fotos/3816> Acesso em 10 jun. 2018.

Figura 6 - Fachada do Trianon, onde foi inaugurada a $1^{\text {a }}$ Bienal do Museu de Arte Moderna. (c) Folhas.

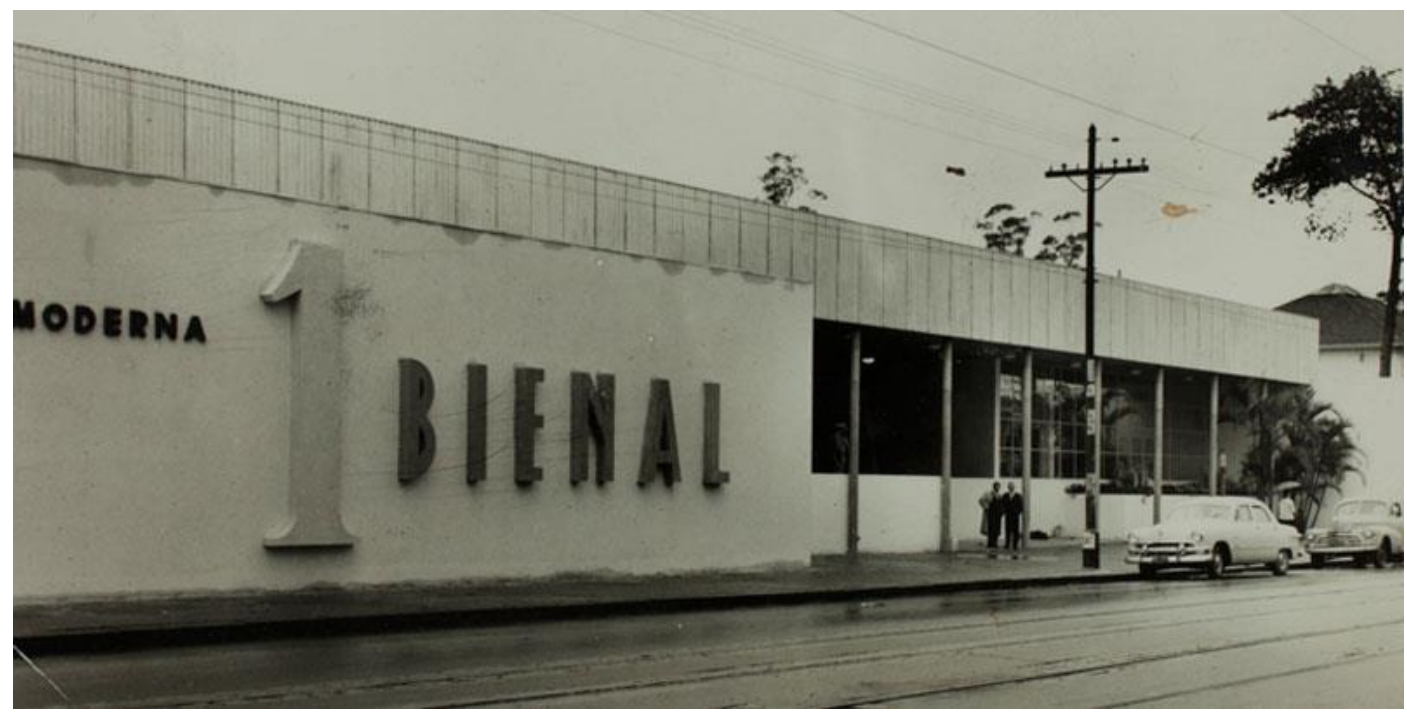

Fonte: FUNDAÇÃO BIENAL DE SÃO PAULO. $1^{\mathbf{a}}$ Bienal de São Paulo. Disponível em: $<$ http://www.bienal.org.br/exposicoes/1bienal/fotos/3800> Acesso em 10 jun. 2018. 
Figura 7 - O casal Yolanda Penteado e Ciccillo Matarazzo (à direita) e Arturo Profilli (à esquerda) na $1^{a}$ Bienal (1951) $\odot$ Cav. Giov. Strazza.

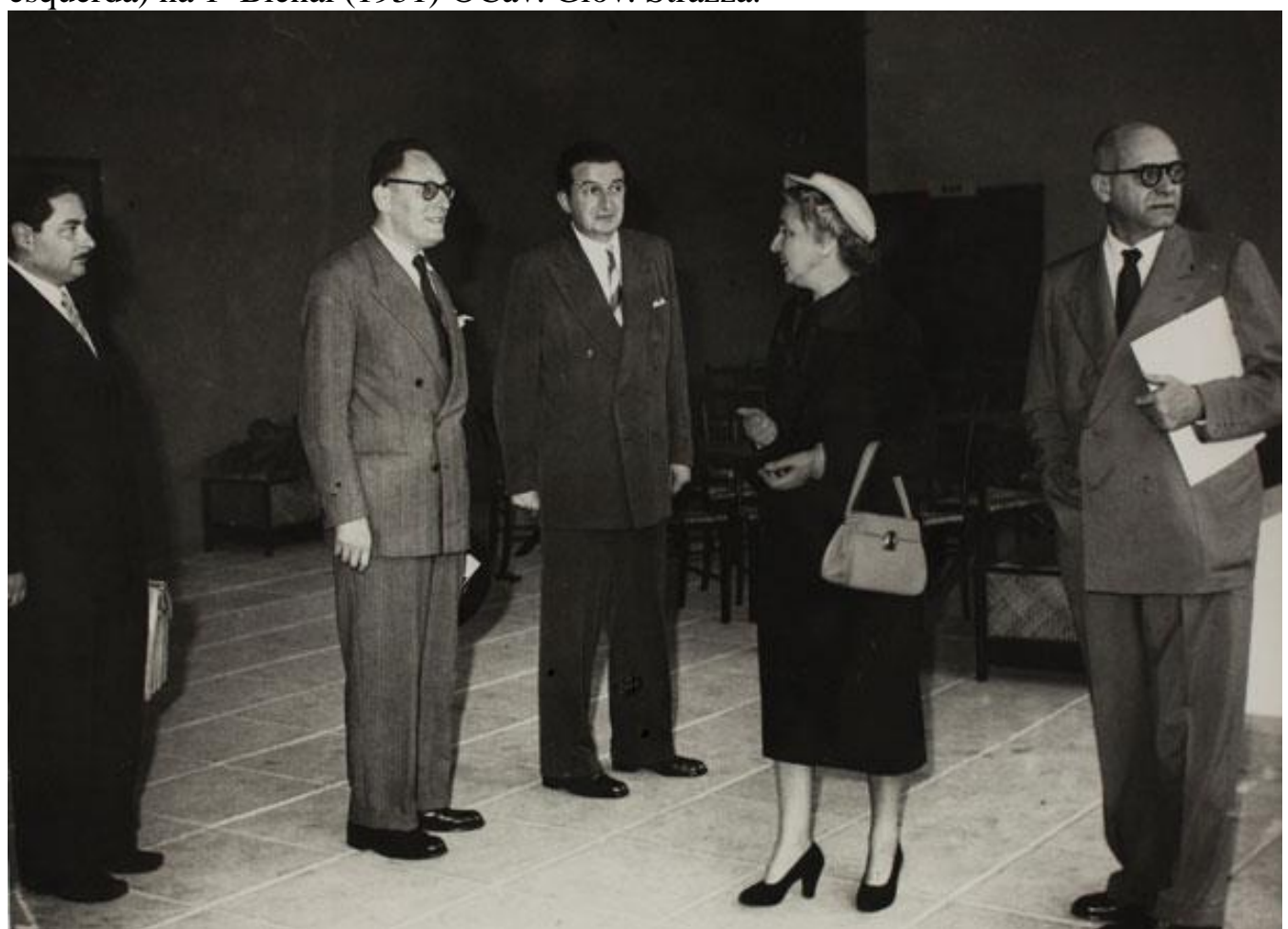

Fonte: FUNDAÇÃO BIENAL DE SÃO PAULO. Yolanda Penteado. Disponível em: $<$ http://www.bienal.org.br/post/565 Acesso em 10/06/2018>. Acesso em 05 jun. 2018.

Figura 8- Inauguração da $1^{\mathrm{a}}$ Bienal. No centro, Darcy Vargas, Yolanda Penteado e Maria Kareska. Em segundo plano, da esquerda para a direita: Victor Brecheret, Tarsila do Amaral, Carlos Prado, Robert Tatin, Marcelo Grassmann, Bruno Giorgi, Frans Krajcberg e Paulo Rossi Osir. ( C Cav. Giov. Strazza.

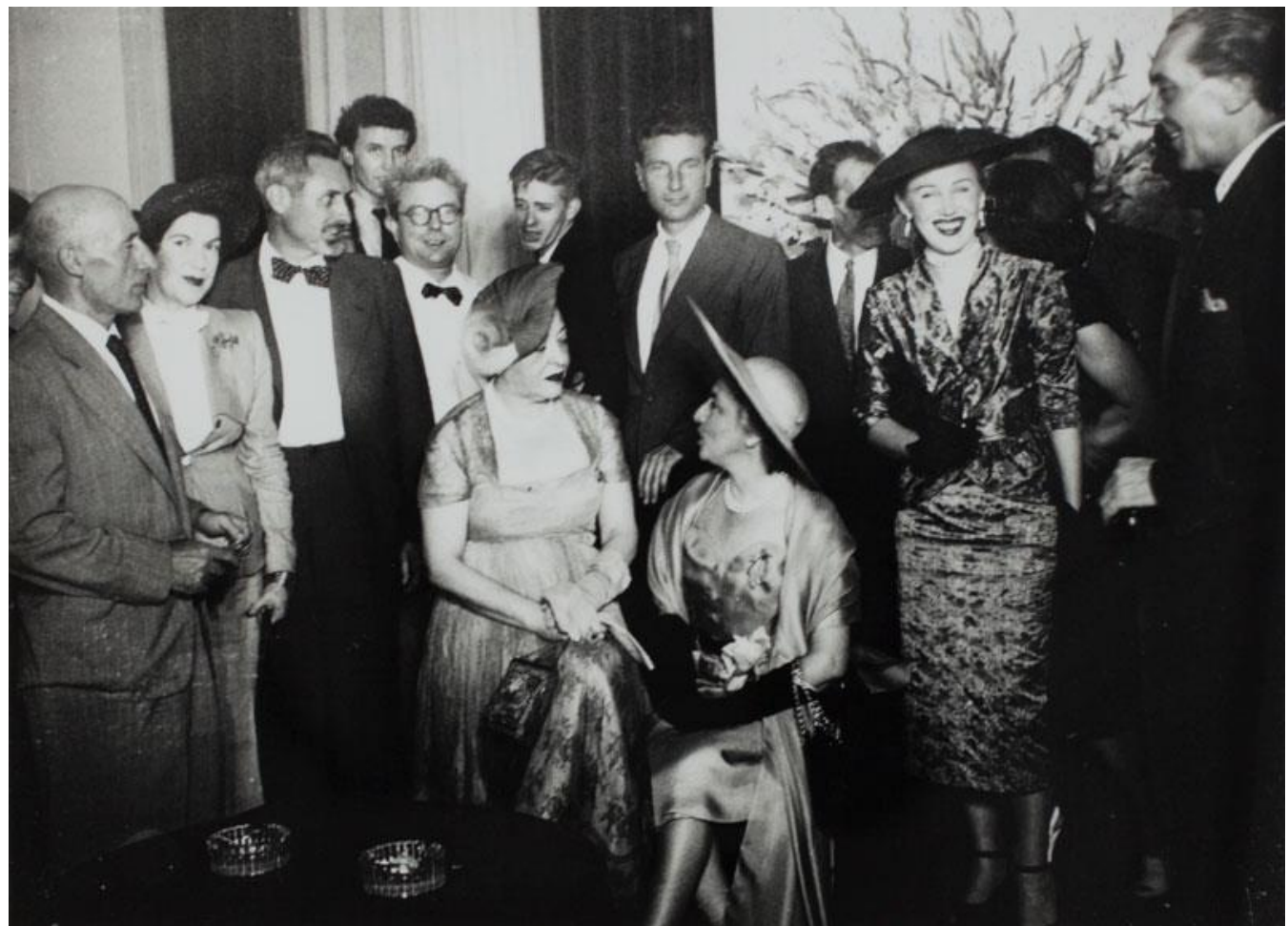

Fonte: FUNDAÇÃO BIENAL DE SÃO PAULO. 1ª Bienal de São Paulo. Disponível em: 〈http://www.bienal.org.br/exposicoes/1bienal/fotos/3806> Acesso em 10 jun. 2018 . 
Figura 9 - Max Bill, Tripartite unit [Unidade Tripartida], na Seção Geral Suíça. Autor não identificado.

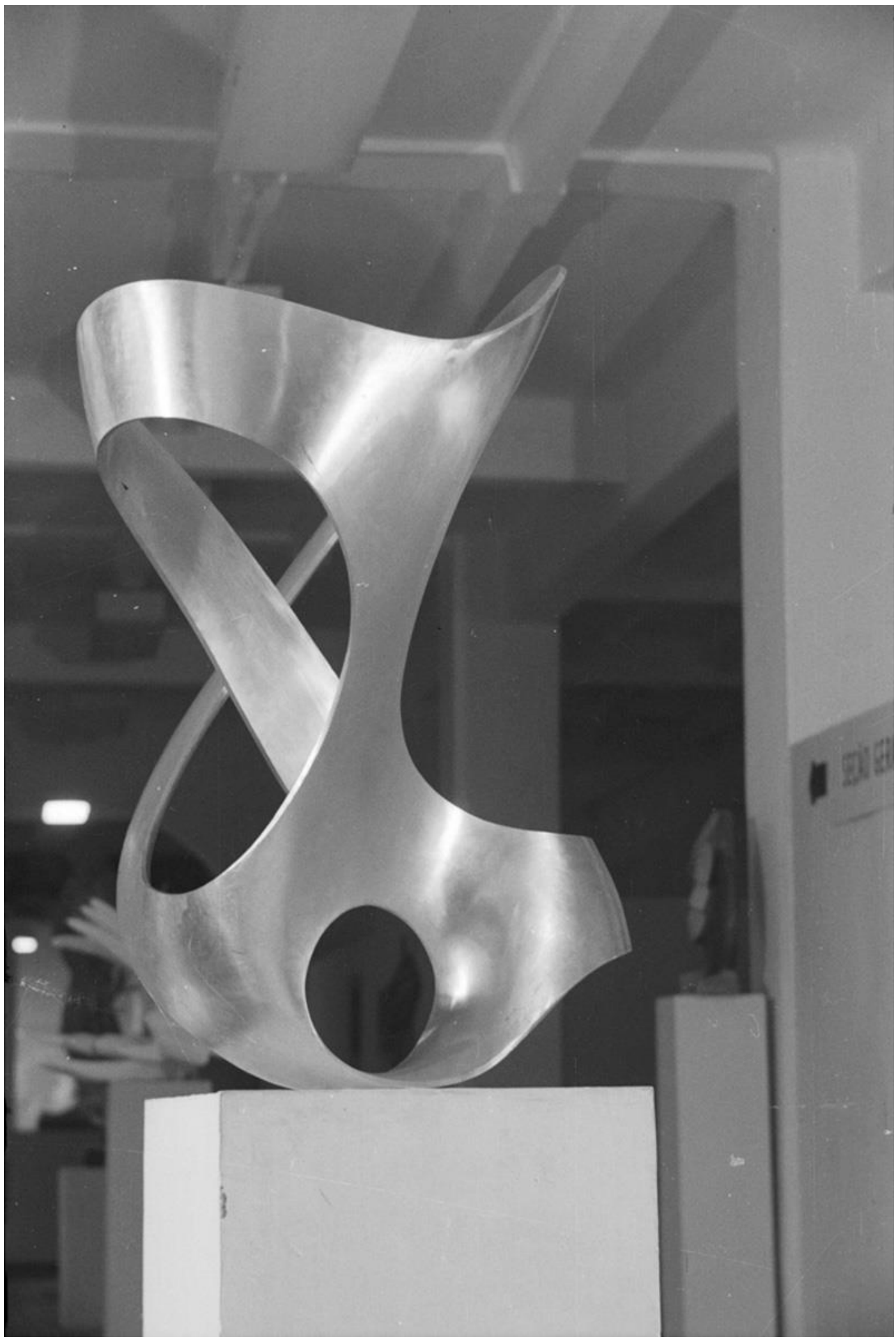

Fonte: FUNDAÇÃO BIENAL DE SÃO PAULO. $1^{\mathbf{a}}$ Bienal de São Paulo. Disponível em: $<$ http://www.bienal.org.br/exposicoes/1bienal/fotos/3815> Acesso em 10 jun. 2018. 
VI Bienal (1961) - Os desafios da organização

\section{9: Precedentes}

É interessante assinalar que o crítico já vinha marcando presença nas eleições para o Júri de Seleção das Bienais de São Paulo (do qual viria a fazer parte na Bienal de 1965) desde a década de 1950, o que pode ser visto como como reflexo de sua atuação junto aos artistas. Apesar de não terem sido encontradas menções anteriores ao fato, Mario Schenberg já tinha figurado entre os nomes votados para o Júri de Seleção da V Bienal, realizada em 1959. Em nota do jornal Crítica de São Paulo, de 6 de maio de 1959, lê-se a distribuição de votos: Fayga Ostrower obteve 37 votos; Geraldo Ferraz teve 35; Alfredo Volpi contou com 18; Lívio Abramo, com 12 e Mario Schenberg teve $9 \operatorname{votos}^{87}$.

Embora o número de votos obtidos por Schenberg tenha sido bastante inferior aos arregimentados por Fayga Ostrower e Geraldo Ferraz, que ficaram em primeiro e segundo lugar, respectivamente, o crítico não estava no fim da lista. Entre os nomes que receberam menos votos, estão Bruno Giorgi, Mário Pedrosa, Sérgio Milliet e mesmo Cândido Portinari ${ }^{88}$.

O Júri de Seleção da V Bienal era composto de forma diversa do que seria feito nas Bienais seguintes. Segundo o regulamento do evento, sua formação envolvia três membros indicados pela Bienal - entre eles, o presidente do Júri - e por mais dois outros, escolhidos pelos artistas. Tinham direito a voto apenas aqueles artistas que já tinham sido aceitos em pelo menos uma das edições anteriores do certame. As cédulas com os nomes indicados eram depositadas numa urna que ficava na secretaria da Bienal, quando da inscrição dos artistas brasileiros ${ }^{89}$.

Desse modo, o Júri foi composto por Paulo Mendes de Almeida (presidente), Ernesto J. Wolf e Mario Barata, como indicados pela Bienal; e por Fayga Ostrower e Alfredo Volpi, eleitos pelos artistas. Observe-se que o crítico Geraldo Ferraz não pôde integrar o Júri de Seleção, ficando Volpi em seu lugar, como terceiro mais votado ${ }^{90}$.

\footnotetext{
${ }^{87}$ Resultado Integral da Votação para Júri da V Bienal, Crítica de São Paulo (capital), 06/05/1959.

${ }^{88}$ Resultado Integral da Votação para Júri da V Bienal, Crítica de São Paulo (capital), 06/05/1959.

${ }^{89}$ FUNDAÇÃO BIENAL. V Bienal. (catálogo de exposição). São Paulo: Fundação Bienal, 1959, p. 30.

${ }^{90}$ FUNDAÇÃO BIENAL. V Bienal. (catálogo de exposição). São Paulo: Fundação Bienal, 1959, p. 15.
} 
De qualquer modo, é interessante notar que, apesar de não figurar entre os primeiros nomes mais votados, o crítico Mario Schenberg já marcava presença na escolha dos artistas com direito a voto. Isso dá a ver que, no fim da década de 1950, o crítico já era considerado como possibilidade para representar os $\operatorname{artistas}^{91}$.

Acredita-se que isso se deva ao fato de que Mario Schenberg já mantinha contato com o meio artístico desde o fim da década de 1930, quando conheceu o pintor Bruno Giorgi, que o apresentou ao Grupo Santa Helena e o incentivou a escrever seu primeiro texto $^{92}$. O surgimento desse grupo se deu com a associação de artistas-artesãos, provenientes do proletariado paulista, na década de 1930, como consequência da reunião espontânea dos mesmos, sem propósitos estéticos estabelecidos (a não ser o vínculo profissional através do ofício de pintura de parede), através da utilização de um mesmo espaço como escritório-ateliê no antigo edifício Santa Helena, então localizado na Praça da Sé, em São Paulo. O primeiro a instalar-se foi Francisco Rebolo em meados de 1934, estabelecendo ali seu escritório de empreiteiro e artista-decorador. Em 1935 começou a pintar, mesmo ano em que Mário Zanini passou a dividir com ele a sala. Algum tempo depois, Zanini alugou uma sala ao lado, assim constituindo o espaço utilizado pelo grupo. Logo se somaram à dupla Manoel Martins, Fulvio Pennacchi, Aldo Bonadei, Clóvis Graciano, Alfredo Volpi, Humberto Rosa e Rizzotti ${ }^{93}$.

A peculiaridade do grupo residia na origem humilde de seus integrantes que possuíam uma formação acadêmica bastante diversa daquela trilhada pelos modernistas. Ficaram conhecidos por suas excursões com a finalidade de pintar ao ar livre, geralmente lugares periféricos onde predominava a paisagem cotidiana da rotina do proletariado (temática predominante na obra do grupo) ${ }^{94}$.

Schenberg conheceu Alfredo Volpi e os outros artistas do Grupo Santa Helena por intermédio de Bruno Giorgi, no início dos anos de 1940. O crítico, que estreitou laços de amizade com esses dois artistas, também participou das aulas de desenho que

\footnotetext{
${ }^{91}$ Além disso, sabe-se que o crítico acompanhou as Bienais desde as primeiras edições, salvo quando estava fora do país. SCHENBERG, Mario. Currículo artístico de Mario Schenberg. Texto depositado no Centro Mario Schenberg de Documentação da Pesquisa em Arte - ECA/USP.

${ }^{92}$ LUVTEN. Jos. Mario Schenberg, amigo dos artistas. A Gazeta. São Paulo, 10 jun. 1972, p. 9. Tratase de "Um estudo sobre Bruno Giorgio", publicado na Revista acadêmica em 1942.

${ }^{93}$ AJZENBERG, Elza Maria (org.). Operários na Paulista: MAC USP e artistas artesãos. Apresentação Horacio Lafer Piva, Elza Maria Ajzenberg; introdução Daisy Valle Machado Peccinini de Alvarado. São Paulo: MAC, 2002.

${ }^{94}$ AJZENBERG, Elza Maria (org.). Operários na Paulista: MAC USP e artistas artesãos. Apresentação Horacio Lafer Piva, Elza Maria Ajzenberg; introdução Daisy Valle Machado Peccinini de Alvarado. São Paulo: MAC, 2002.
} 
Figura 10 - Fotografia do antigo Palacete Santa Helena, demolido em 1971, quando da construção da estação do Metrô da Sé.

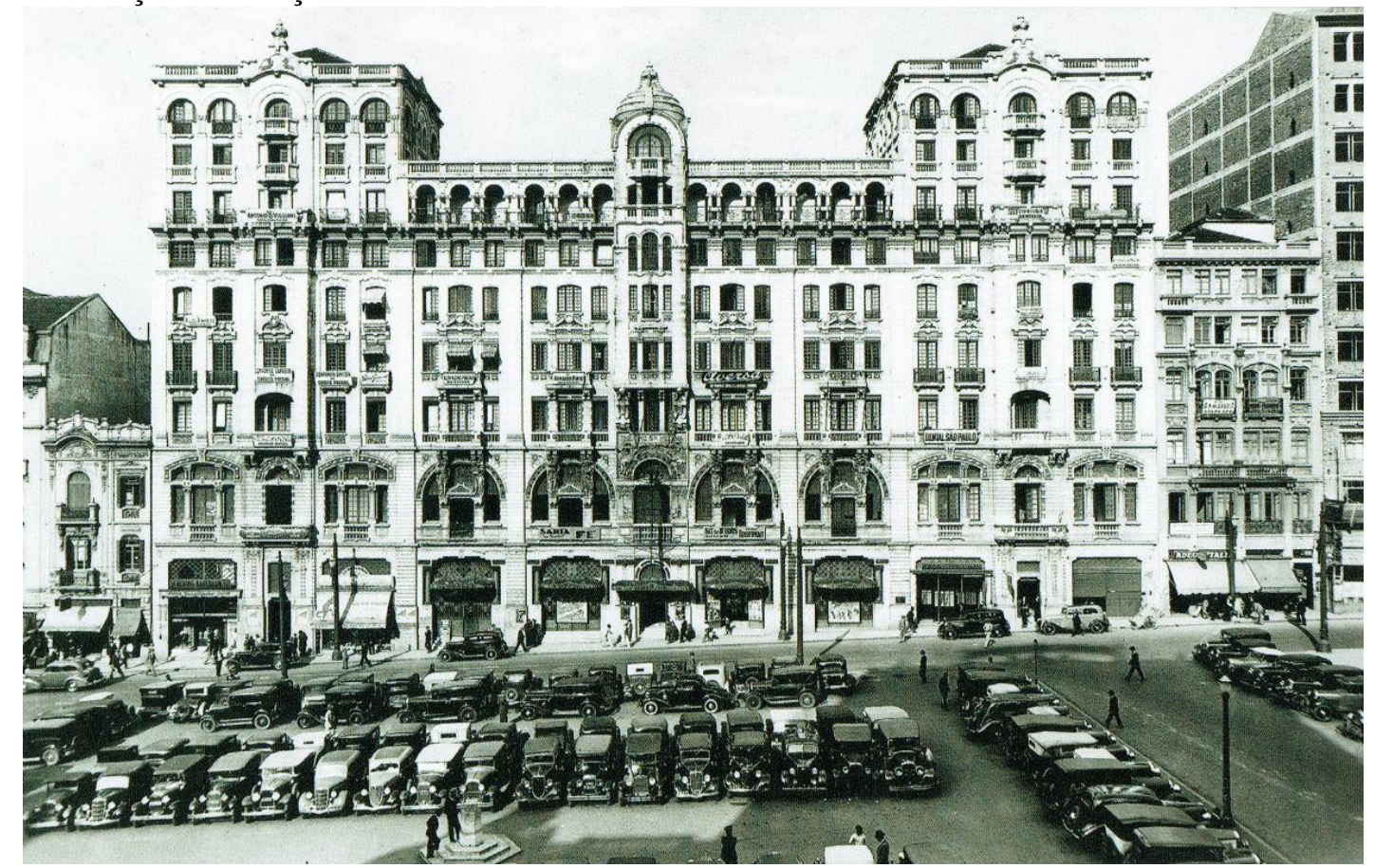

Fonte: CARTA CAPITAL. O esplendor proletário e o Grupo Santa Helena. Disponível em <https://www.cartacapital.com.br/revista/902/o-esplendor-proletario> Acesso em 02 mar. 2018.

aconteciam no palacete Santa Helena nesse período, chegando, por vezes, a ceder sua própria residência para que as aulas ocorressem ${ }^{95}$.

Além disso, a partir de 1939, Schenberg passa a frequentar, também, a residência de Oswald de Andrade. Lá, conhece o pintor José Oswald de Andrade e escultora e desenhista Teresa d'Amico ${ }^{96}$, sobre a qual escreverá no futuro. Na década de 1940, o crítico cultivou amizades, ainda, com artistas como Pancetti, Lazar Segal e Portinari. Em 1944, Schenberg organizou a primeira exposição individual deste Alfredo Volpi, tendo fotografado as obras para o catálogo e escrito o texto de abertura ${ }^{97}$. A partir de então, o nome do artista ficou cada vez mais conhecido entre os artistas.

Nesse contexto, pode-se dizer que o círculo artístico no qual o crítico estava inserido desde o final dos anos de 1930 reúne muitos dos principais nomes, não apenas do já reconhecido Movimento Modernista, mas também muitos dos artistas que, nas décadas seguintes, despontariam no cenário artístico nacional.

\footnotetext{
${ }^{95}$ OLIVEIRA, Alecsandra Matias. Schenberg: Crítica e Criação. São Paulo: EDUSP, 2011.

${ }^{96}$ Currículo Artístico de Mario Schenberg Centro Mario Schenberg de Documentação da Pesquisa em Arte-ECA/USP.

${ }^{97}$ Cf. OLIVEIRA, Alecsandra Matias. Schenberg: Crítica e Criação. São Paulo: EDUSP, 2011.
} 
Essa convivência do crítico com os artistas se daria de forma contínua e intensa, tanto que, já em 1972, havia uma anedota circulando nos meios artísticos de São Paulo: "[f]alava-se de um artista tão desconhecido, mas tão desconhecido, que nem o próprio Mario Schenberg o conhecia" 98 . Pode-se falar, nesse sentido, da figura do crítico como um promotor cultural, cuja inserção no meio artístico da época ia além da atividade de crítico de arte e da organização de exposições.

\section{Sala Especial de Alfredo Volpi}

A VI Bienal do Museu de Arte Moderna de São Paulo teve lugar no Pavilhão Armando Arruda Pereira (Pavilhão da Bienal), entre 1 de outubro e 21 de dezembro de 1961. Tendo como diretor geral o crítico de arte Mario Pedrosa, a mostra reuniu 651 artistas provenientes de 50 países, expondo ao público quase 5.000 obras $^{99}$.

Chegando a sua sexta edição, o evento já tinha suscitado diversas polêmicas. Desde a repercussão do apoio de Nelson Rockefeller quando de sua criação, passando pelo gigantismo das sucessivas edições, até os debates acerca da abstração versus figuração e da emergência das vanguardas dos anos de $1960^{100}$. Pode-se dizer que a cada dois anos, em maior ou menor medida, escolhas e renúncias dos organizadores da Bienal de São Paulo catalisavam e inventariavam os debates em voga na esfera cultural e artística do país.

Esta edição foi a última ligada ao Museu de Arte Moderna de São Paulo, (MAMSP), fundado por Francisco Matarazzo Sobrinho em 1948. Foi também a última edição que contou com uma organização centralizada na figura de um Diretor Geral, função ocupada então por Mário Pedrosa. Da VII Bienal em diante, a organização do evento contaria apenas com Comissões de Assessoria e, a partir da XI Bienal, em 1971, com uma Assessoria Técnica ${ }^{101}$. Após a separação entre a Fundação Bienal e o MAM - SP,

\footnotetext{
${ }^{98}$ Mario Schenberg, amigo dos artistas. Jornal A Gazeta. São Paulo, 10/06/1972, pág. 9.

${ }^{99}$ FUNDAÇÃO BIENAL. Bienal a Bienal. Disponível em: http:/www.bienalorg.br//FBSP/pt/AHWS/BienalaBienal/Paginas/6BienalSaoPaulo.aspx?selected=6 Acessado em 15 jan. 2013.

${ }^{100}$ ALAMBERT, Alambert \& Polyana CANHÊTE. Bienais de São Paulo: da era do museu à era dos curadores. São Paulo: Boitempo, 2004.

${ }^{101}$ A comissão artística deixou de existir, tendo sido substituída por uma comissão cujos integrantes eram indicados por Ciccillo Matarazzo, presidente da Fundação Bienal, criada no ano seguinte (1962). Nem sempre havia nessas comissões conhecedores de arte, o que comprometia a qualidade da mostra. Essa crítica acompanhou as Bienais desde sua separação do MAM-SP. Cf. ALAMBERT \& CANHÊTE (2004); AMARANTE (1989).
} 
Mário Pedrosa participou da organização de algumas edições seguintes, porém ocupando outras funções.

Com Mário Pedrosa na direção geral da mostra, a expectativa era que a edição de 1961 tivesse um caráter fortemente pautado pelas pesquisas de vanguarda. Contudo, sua proposta foi mais tímida, apoiando-se em retrospectivas históricas. Várias representações internacionais tiveram caráter museológico. Sobre isso, a pesquisadora Leonor Amarante observou que:

Seu brilho [de Mário Pedrosa] incontestável como crítico e teórico não foi o mesmo na função de curador. A exposição foi pouco instigante, faltou-lhe ousadia. O espaço que dedicou para obras de caráter histórico e museológico foi excessivo. Embora a maioria das salas fosse interessante, exposições dessa natureza não se justificam em bienais que pretendiam enfocar o que acontecia na arte contemporânea ${ }^{102}$.

Mário Pedrosa, contudo, tinha motivos fortes para fazer as escolhas que fez ao organizar essa bienal. Estando à frente do Museu de Arte Moderna de São Paulo, o crítico entendia que, no contexto histórico vivido pelo Brasil, era função dos Museus não somente funcionar como lugar de experimentação, mas também socializar a arte e cumprir uma função educativa entre as classes sociais que não pertenciam às elites ${ }^{103}$. Por um lado, a Bienal tinha o propósito de trazer o que havia de mais novo em arte. Por outro, no país, era preciso formar o público e suprir uma defasagem de um país que praticamente não tinha museus, nem grandes acervos internacionais. Por isso, dentro do projeto de Pedrosa para a VII Bienal, não só a representação brasileira, mas diversas delegações estrangeiras tiveram cunho museológico.

Dentro desse projeto, estavam previstas, na representação brasileira, salas especiais para os laureados das primeiras edições da Bienal ${ }^{104}$. Coube a Mario Schenberg a organização de uma retrospectiva da obra de Alfredo Volpi, que ocupou uma das salas especiais da representação brasileira da VI Bienal de Arte de São Paulo ${ }^{105}$. O pintor das bandeirinhas dividiu com Di Cavalcanti o Prêmio Nacional de Pintura na

\footnotetext{
102 AMARANTE, Leonor. As Bienais de São Paulo: 1951 a 1987. São Paulo: Projeto, 1989, p. 108. ${ }^{103}$ PEDROSA, Mário. Depoimento sobre o MAM. In: ARANTES, Otília (Org.). Mário Pedrosa/política das artes. São Paulo: Edusp, 1995. p. 299-308.

${ }^{104} \mathrm{O}$ projeto foi apresentado por Mário Pedrosa, nesses termos, aos críticos convidados para organizar as salas especiais, conforme o modelo da carta-convite enviada, com pequenas mudanças, a cada um deles (Arquivo Wanda Svevo/ Fundação Bienal).

${ }^{105}$ FUNDAÇÃO BIENAL. VI Bienal. (catálogo de exposição) São Paulo: Fundação Bienal, 1961.
} 
II Bienal, em 1953, escolha que se deu no contexto do debate entre o realismo social e o abstracionismo emergente ${ }^{106}$.

O debate abstração versus figuração, marcou a tensão entre a arte concreta e o realismo socialista soviético pregado pelo Partido Comunista nos anos de 1950. Nesse contexto, a decisão do júri de premiação em dividir o prêmio entre Di Cavalcanti, cuja obra refletia a orientação do realismo social, e Alfredo Volpi, cujo trabalho apontava para uma sensibilidade construtiva mais próxima do concretismo que emergia então, foi bastante significativa e gerou polêmica. Isso porque, naquele momento, o realismo socialista soviético e a arte acadêmica difundida pelas instituições de ensino formal do país (cujo referencial era a Europa) dominavam o cenário das artes plásticas do país ${ }^{107}$.

Apesar de sua atuação política como militante do Partido Comunista, Schenberg se distanciou de sua orientação artística. Em lugar disso, o crítico apoiava as vanguardas emergentes desde a década de 1950 (e também posteriormente), pois considerava que estariam mais abertas às recentes demandas do momento histórico, podendo responder melhor ao desafio da descoberta de seus valores em gestação ${ }^{108}$.

Schenberg era, já na época, um dos maiores conhecedores da personalidade e da obra do artista, tendo sido o primeiro a perceber, por volta dos anos de 1940, a importância da obra do pintor operário de origem humilde ${ }^{109}$. Mario Schenberg havia organizado, em 1944, a primeira exposição individual de Alfredo Volpi, para a qual fotografara as obras e escrevera o texto de apresentação para o catálogo da mostra ${ }^{110}$. Sobre isso, Aracy Amaral destaca que

${ }^{106}$ AMARANTE, Leonor. As Bienais de São Paulo: 1951 a 1987. São Paulo: Projeto, 1989.

${ }^{107} \mathrm{~A}$ arte concreta representou, até os anos de 1960, a principal alternativa à forte presença do realismo oficial, regionalista, propagado pela esquerda oficial do país. Essa era a orientação do Partido Comunista e também da academia, que já havia institucionalizado as vanguardas trazidas pelo Modernismo nas primeiras décadas do século XX (BRITO, Ronaldo. Neoconcretismo: Vértice e ruptura do projeto construtivo brasileiro. São Paulo: Cosac \& Naify, 1999).

${ }_{108}$ Cf. SHCNBERG, Mário. O espaço social do Artista. Arquivo Centro Mário Schenberg de Documentação e Pesquisa em Artes. Texto sem não numerado e não datado. Cabe dizer ainda que a intuição, para o crítico de arte, não era privilégio de alguns eleitos, mas uma faculdade que todos os seres humanos possuíam, podendo desenvolvê-la em maior ou menor medida. Sobre isso, cf. Alecsandra Matias de Oliveira. Schenberg: crítica e criação. São Paulo Edusp, 2011.

${ }^{109}$ AJZENBERG, Elza. Mario Schenberg - O Crítico. In AGUILAR, José Roberto. O mundo de Mario Schenberg. São Paulo: Casa das Rosas, 1996. Em 1953, Schenberg havia retornado ao Brasil após uma estadia de cinco anos na Bélgica, nos quais lecionou na Universidade de Bruxelas, dedicando-se às atividades científicas. Foi nomeado Diretor do Departamento de Física da então chamada Faculdade de Filosofia, Ciências e Letras da USP, o que diminuiu sua disponibilidade de tempo para a crítica de arte. E, 1961, quando deixou o cargo, Schenberg pôde retomá-la de modo mais sistemático, principalmente por meio do contato com Alfredo Volpi e Mário Pedrosa. Até 1969, quando foi afastado da Universidade de São Paulo, Schenberg atuou no meio artístico com menor intensidade, o que não quer dizer que sua crítica de arte tenha sido menos significativa.

${ }^{110}$ OLIVEIRA, Alecsandra Matias de. Schenberg: crítica e criação. São Paulo: EDUSP, 2010, p. 108. 
[d]esde 1944, quando realiza sua primeira individual na Galeria Itá, em São Paulo, aos 48 anos, apresentado pelo físico Mario Schenberg, Volpi começou a ter colecionadores apaixonados por seu trabalho. Schenberg foi, indiscutivelmente, o primeiro deles, seguido pelo crítico e poeta Theon Spanudis, que reuniu grande coleção, em parte posteriormente doada ao MAC-USP. Uma segunda geração de "volpistas" incluiu colecionadores como Anita Marques da Costa e João Marino. Uma terceira leva de admiradores colecionistas, a partir de fins da década de [19]60, seria integrada por Domingos Giobbi, Maria Helena Ortiz e, pouco depois, Ladi Biezus e Marco Antonio Mastrobuono, sem mencionar marchands e, desde o início da década de 1950, artistas plásticos, sempre alertas à produção de Volpi. ${ }^{111}$

Em carta datada de 2 de fevereiro de 1961, Mário Pedrosa escreve a Mario Schenberg confirmando o acerto prévio feito em conversa telefônica e manifestando satisfação em confiar ao crítico a organização da retrospectiva de Volpi. Essa tarefa tinha sido proposta inicialmente a Theon Spanoudis, que foi escolhido pelo pintor, mas não pôde aceitar a incumbência, pois estaria em viagem no período em questão ${ }^{112}$.

Mas o que teria motivado a escolha desses dois críticos por parte de Alfredo Volpi? É possível que sua opção, quando consultado por Mario Pedrosa, tenha levado em conta uma conferência realizada alguns anos antes, ainda nos anos de 1950.

Em 25 de maio de 1956, foi aberta, no Museu de Arte Moderna de São Paulo, uma exposição individual contendo obras da fase mais recente do pintor ${ }^{113}$. A mostra, que foi organizada por Theon Spanoudis, teve boa repercussão, dado que o pintor, nesse ponto de sua carreira, já era um nome de peso no cenário artístico nacional.

No mês seguinte, mais precisamente em 11 de junho de 1956, com a finalidade de aquilatar o valor dos trabalhos realizados na fase mais recente do pintor, o Conselho Artístico do Museu realizou uma conferência sobre sua obra ${ }^{114}$. O evento teve lugar no próprio salão do Museu de Arte Moderna, onde estava instalada a exposição, e foi acompanhada por um público que ocupou todo o espaço.

A cobertura da conferência por parte do Jornal da Noite de 18 de junho de 1956 publicou, exatamente uma semana após a realização do evento, fotos (aqui reproduzidas

\footnotetext{
${ }^{111}$ AMARAL, Aracy. A visão do colecionador. In Volpi: pequenos formatos. São Paulo: Museu de Arte Moderna de São Paulo, 2016, p. 9.

${ }^{112}$ Carta de Mário Pedrosa a Mario Schenberg, de 02 de fevereiro de 1961; carta de Mário Pedrosa a Theon Spanudis, de 22 de dezembro de 1960 (Arquivo Histórico Wanda Svevo). A resposta de Theon Spanoudis não foi encontrada no Arquivo Histórico da Bienal, mas Pedrosa faz referência a ela na primeira carta mencionada, bem como ao motivo que o levou a não aceitar o convite.

${ }^{113}$ O Estado de São Paulo. São Paulo (capital) 10 abr. 1956.

${ }^{114}$ PACOTE, E. Três horas de debates sobre a obra de Volpi no Museu de Arte Moderna. Folha da Noite, São Paulo (capital) 18 jun. 1956.
} 
nos anexos) e uma resenha dos debates, que serão melhor analisados a diante. Os debates foram abertos por Spanoudis, e contaram com a presença de José Geraldo Vieira (que presidiu os trabalhos), Samson Flexor, Carlos Pinto Alves, Mario Schenberg e Waldemar Cordeiro ${ }^{115}$.

Por meio da repercussão do evento na imprensa, não é difícil constatar que "Mário Schenberg - antigo crítico de arte e um dos maiores conhecedores da obra de Volpi, da qual possui alguns dos exemplares mais significativos - foi quem produziu a intervenção mais substanciosa e aplaudida" ${ }^{116}$. Apesar de os debates terem se dado num plano de grande elaboração teórica, acredita-se que o crítico soube colocar sua visão de modo a se fazer entender tanto pelos demais críticos, quanto pelo público presente ao evento.

Contudo, cabe a pergunta: o que fez com que Mario Schenberg tivesse sucesso nessa enorme tarefa, que foi a organização de uma retrospectiva na VI Bienal? Acreditase que, além do grande conhecimento acerca da obra e da personalidade de Volpi, pelo que o crítico já era reconhecido então, há outro fator relevante: sua familiaridade com o circuito artístico, que datava do final da década de 1930, sendo que seu nome já era votado para o Júri de Seleção da Bienal desde 1959.

No Arquivo Histórico Wanda Svevo (Fundação Bienal), a documentação acerca da organização da exposição é extensa. Foram inúmeras solicitações de empréstimos de obras, pertencentes a muitos proprietários diferentes. Muitos deles, sabe-se, tinham proximidade com o crítico, como Mário Pedrosa, Theon Spanoudis e Bruno Giorgi ${ }^{117}$, por exemplo. Tendo-se em vista os numerosos contatos mobilizados por Mario Schenberg, pode-se afirmar que seu sucesso na organização da sala especial se deu por conta de sua forte inserção no meio artístico da época, não apenas enquanto crítico de arte, mas também como incentivador dos artistas com os quais convivia ${ }^{118}$.

De volta à retrospectiva de Alfredo Volpi, para organiza-la, Mario Schenberg teve que contornar uma dificuldade: reunir trabalhos de todas as fases de um pintor cuja carreira fora iniciada na década de 1920, junto ao Grupo Santa Helena. Contando então com uma trajetória de quatro décadas, que compreendeu inúmeras fases, sua obra

\footnotetext{
${ }^{115}$ Diário de Notícias, 15 jul. 1956.

${ }^{116}$ Diário de Notícias, 15 jul. 1956.

117 Arquivo Histórico Wanda Svevo, Fundação Bienal.

118 PISMEL, Ana Paula Cattai. Schenberg e vanguardas: Crítica como parceria. In: VIII Congresso de Estética e História da Arte, Desenhos da Pesquisa: Novas Metodologias da Pesquisa em Arte. São Paulo: Museu de Arte Contemporânea da Universidade de São Paulo, 2012. v.1. p.279 - 288.
} 
oferecia um desafio e tanto à realização de uma exposição retrospectiva. Essa dificuldade foi ainda maior com relação aos trabalhos anteriores à década de 1940, que já estavam bastante dispersos. No texto de apresentação da mostra, o crítico observou que a "[...] maior parte dos trabalhos de decoração de residências foram destruídos. Com grande esforço foi possível reunir uma coleção reduzida de seus quadros do período de 1915-1940 para a presente retrospectiva" ${ }^{119}$.

Figuraram na mostra 95 obras, em ordem cronológica, num percurso que cobriu desde 1915, como a tela Casebre, à pesquisa de 1961, com Bandeirolas no Espaço ${ }^{120}$. Para Leonor Amarante, a sala especial teve o mérito de ter sido "a primeira oportunidade de se ver quase todas as [...] fases" do pintor $^{121}$.

Foram inúmeras as negociações com proprietários de obras do pintor. No Arquivo Histórico Wanda Svevo, da Fundação Bienal, estão depositados inúmeros recibos de empréstimo e devolução de obras pertencentes a diversos proprietários, entre eles, Francisco Matarazzo Sobrinho, Mário Pedrosa, o pintor Bruno Giorgi e o próprio Mario Schenberg ${ }^{122}$. Apesar da trabalhosa, a montagem da exposição foi bem sucedida.

Entretanto, no decorrer do evento de abertura da mostra, a saber, 1 de outubro de 1961, um incidente danificou algumas das obras da sala especial, sendo que apenas uma delas estava segurada ${ }^{123}$. Três telas de propriedade particular foram manchadas de branco por conta da queda acidental de um extintor de incêndio que teria explodido ${ }^{124}$. As telas em questão eram as seguintes: Bandeirolas Verdes (1961, têmpera, 72 x 72 cm) e Torres (1851, têmpera, 135 x $81 \mathrm{~cm}$ ), ambas pertencentes a J. Carvalho ${ }^{125}$; e Casa Negra (1861, têmpera, 72 x 55 cm), da Coleção Mario Schenberg ${ }^{126}$.

Sabe-se do ocorrido por meio de carta enviada por José de Carvalho ${ }^{127}$ ao Museu de arte Moderna, junto da qual segue, em outra carta, um relato testemunhal sobre como

\footnotetext{
${ }^{119}$ SCHENBERG, Mario. Alfredo Volpi. In FUNDAÇÃO BIENAL. VI Bienal. (catálogo de exposição) São Paulo: Fundação Bienal, 1961, pp.38-39.

${ }^{120}$ FUNDAÇÃO BIENAL. VI Bienal. (catálogo de exposição) São Paulo: Fundação Bienal, 1961.

${ }^{121}$ AMARANTE, Leonor. As Bienais de São Paulo: 1951 a 1987. São Paulo: Projeto, 1989, p. 117.

${ }^{122}$ Arquivo Histórico Wanda Svevo, Fundação Bienal.

${ }^{123}$ Quase destruídas três telas de Volpi, na Bienal, O Globo (estado da Guanabara), 05 out. 1961.

${ }^{124}$ Extintor danifica Volpi. Folha de São Paulo. $2^{\mathrm{a}}$ edição, São Paulo (capital), 05 out. 1961.

${ }^{125}$ Carta a J. Carvalho, datada de 24/08/1961, assinada por Francisco Matarazzo Sobrinho solicitando o empréstimo das obras para a sala especial. Arquivo Histórico Wanda Svevo/Fundação Bienal. Além delas, J. carvalho tinha ainda a tela Bandeirolas no Espaço, de 1961 (têmpera, 72 × $72 \mathrm{~cm}$ ), que não foi danificada. A grafia original da carta foi mantida, mas é necessário observar que se trata de Ermano Marchetti.

126 Apólice de Seguros da Companhia Seguradora da Bahia. Museu de Arte Moderna e Mario Schenberg. 25 ago. 1961. Arquivo Histórico Wanda Svevo/Fundação Bienal.

${ }^{127}$ Carta de José de Carvalho, da Petite Galerie, ao Museu de Arte Moderna, de 17 set. 1961. Arquivo Histórico Wanda Svevo/Fundação Bienal.
} 
os danos teriam sido feitos. Nesse relato, Biaggio Motta ${ }^{128}$ afirma que, pouco depois da cerimônia formal de abertura da VI Bienal, foi atraído ao espaço da sala especial de Alfredo Volpi por uma movimentação incomum. Quando chegou ao local, encontrou uma pequena multidão em volta de um homem que mantinha nos braços um extintor de incêndio cujo jato era projetado contra os quadros expostos. Este manteve-se na mesma posição até que o conteúdo do extintor se exaurisse, apesar dos apelos dos presentes para que ele mudasse a direção do jato, com a finalidade de não danificar as obras.

Ainda segundo o mesmo relato, o homem mencionado foi identificado, mais tarde, como Sr. Ermanno Marchetti, então vereador com acento à Câmara Municipal. O Sr. Motta afirmou que acreditava que, diante da pequena confusão formada para acompanhar a comitiva presidencial, o Sr. Marchetti teria derrubado o extintor por acidente $^{129}$.

Diante desse acontecimento, Mario Schenberg, que havia feito, por meio do Museu de Arte Moderna, o seguro das obras que emprestou à retrospectiva de Alfredo Volpi, recebeu o prêmio em 16 de janeiro de $1962^{130}$, após a efetivação dos trâmites previstos na apólice. Por conta dos danos ao quadro Casa Negra, de 1961, o crítico recebeu a quantia de $\mathrm{Cr} \$ 80.000,00$ (oitenta mil cruzeiros) ${ }^{131}$.

A apólice de seguro foi feita pelo Museu de Arte Moderna, em nome de Mario Schenberg, e por sua conta, em 25 de agosto de 1961, estendendo-se a todos os quadros de sua propriedade que foram cedidos para exposição da sala especial. A tela Casa Negra (1861, têmpera, $72 \times 55 \mathrm{~cm}$ ), aparece entre as 13 telas relacionadas na lista da apólice, tendo sido segurada no valor de 80.000,00 cruzeiros (salvo uma delas, de maiores dimensões, que teve valor maior - de 1000.000,00 cruzeiros) $)^{132}$.

\footnotetext{
${ }^{128}$ Biagio Motta e Frederico Melcher eram proprietários da Galeria Documenta, que na época estava situada à Rua Padre João Manuel, no centro de São Paulo. MUSEU AFROBRASIL. Reunida ao longo de 50 anos, coleção de Emanoel Araujo é exposta no Museu Afro Brasil. Disponível em: <http://www.museuafrobrasil.org.br/programacaocultural/exposicoes/temporarias/detalhe?title $=\% 22 \mathrm{O}+$ que $+\mathrm{os}+\mathrm{olhos}+\mathrm{n} \% \mathrm{C} 3 \% \mathrm{~A} 3 \mathrm{o}+\mathrm{v} \% \mathrm{C} 3 \% \mathrm{AA} \% 2 \mathrm{C}+\mathrm{O}+$ cora $\% \mathrm{C} 3 \% \mathrm{~A} 7 \% \mathrm{C} 3 \% \mathrm{~A} 30+\mathrm{n} \% \mathrm{C} 3 \% \mathrm{~A} 30+$ sente $\% 22+-$

$+\mathrm{A}+$ arte+de+todo+mundo $\% 3 \mathrm{~A}+50+$ anos+de+viv\%C3\%AAncias $>$ Acesso em: 13 fev. 2016.

${ }^{129}$ Carta de Biagio Motta à Diretoria do Museu de Arte Moderna, de 17 set. 1961. Arquivo Histórico Wanda Svevo/Fundação Bienal.

${ }^{130}$ Carta da Secretaria da Bienal de São Paulo a Mario Schenberg, de 16 jan. 1962. Arquivo Histórico Wanda Svevo/Fundação Bienal. No mesmo arquivo encontram-se, ainda, a apólice de seguro da tela e o recibo assinado por Schenberg quando do recebimento do valor do seguro.

131 Apólice de Seguros da Companhia Seguradora da Bahia. Museu de Arte Moderna e Mario Schenberg. 25 ago. 1961. Arquivo Histórico Wanda Svevo/Fundação Bienal.

132 Apólice de Seguros da Companhia Seguradora da Bahia. Museu de Arte Moderna e Mario Schenberg. 25 ago. 1961. Arquivo Histórico Wanda Svevo/Fundação Bienal.
} 
Segundo o que se pode supor pelos documentos encontrados, apenas Mario Schenberg e Willis de Castro contrataram seguros para as obras que estavam cedendo para exposição na VI Bienal. É possível que mais proprietários tivessem esse hábito, porém isso não pode ser aferido pela documentação, da qual constam apenas as duas apólices mencionadas.

No que diz respeito ao texto de apresentação da retrospectiva, o crítico busca dar ao público a dimensão das fases da pesquisa de Alfredo Volpi, apresentando alguns aspectos de sua extensa produção. Ao destacar a capacidade de síntese do pintor, seja na captação da essência da atmosfera de cidadezinhas, subúrbios e praias, seja nas composições da fase do abstracionismo geométrico, Mario Schenberg utiliza elementos da pintura oriental: "Volpi evoca a arte inefável dos paisagistas místicos da China e do Japão [...], mas sempre como um homem do povo de São Paulo"133.

O crítico identifica a síntese operada pelo pintor, aliada à musicalidade de suas composições, à dimensão do trabalho dos artistas orientais que, no processo de seu aprendizado, buscavam na simplificação do desenho e no ritmo do traço uma expressividade mais profunda.

Para Mario Schenberg, Volpi é o pintor do espaço metafísico, repleto de musicalidade, no qual a cor não está a serviço da sensualidade (aqui entendida como aspecto do sensível, da sensação visual, e não no sentido do senso comum), mas da expressão de uma "espiritualidade fria e vibrante, um sentimento cósmico transcendendo a sensualidade das aparências" ${ }^{134}$.

Também são examinadas no texto as influências do abstracionismo geométrico e do concretismo, enquanto movimentações mais recentes de sua obra naquele momento. Mario Schenberg indica que, de início, elas pareceram nocivas ao desenvolvimento da pesquisa de Volpi, preocupação que, mais tarde, foi afastada pelo

poderoso temperamento artístico de Volpi pôde [que] receber a influência do abstracionismo geométrico e do concretismo sem perder as suas características próprias. O resultado foi uma maior liberdade, aliada a uma depuração da composição e do colorido, que lhe deram uma admirável capacidade de síntese ${ }^{135}$.

${ }^{133}$ SCHENBERG, Mario. Alfredo Volpi. In FUNDAÇÃO BIENAL. VI Bienal. (catálogo de exposição) São Paulo: Fundação Bienal, 1961, p. 37.

${ }^{134}$ SCHENBERG, Mario. Alfredo Volpi. In FUNDAÇÃO BIENAL. VI Bienal. (catálogo de exposição) São Paulo: Fundação Bienal, 1961, p. 37.

${ }^{135}$ SCHENBERG, Mario. Alfredo Volpi. In FUNDAÇÃO BIENAL. VI Bienal. (catálogo de exposição) São Paulo: Fundação Bienal, 1961, p. 38. 
Essa libertação da representação, prossegue o crítico, permitiu ao pintor desenvolver ainda mais seu senso de espacialidade pura, notável desde suas marinhas de Itanhaém (1940-1942). O pintor conseguiu plasmar, usando grandes massas de tons puros, uma espacialidade de vibração belíssima que, segundo o crítico, foi criação original sua. Os espaços, coloridos uniformemente, buscavam afastar a impressão de matéria.

Nos desdobramentos dos dois anos anteriores, porém, Volpi vinha se afastando do concretismo: estava voltando "à procura de matéria, e mesmo da pincelada, retomando de modo novo métodos tradicionais da pintura ocidental. [...] [N]as composições semi-abstratas ou abstratas surgem cada vez mais linhas e curvas irregulares"136.

Apesar de apresentarem muitas qualidades, como a beleza da composição, a pureza do colorido e os temas populares, o conjunto da obra de Volpi produzida sob encomenda se apresenta menos interessante, para o crítico, que as telas pintadas na trilha de sua pesquisa pessoal - abstrata ou semi-abstrata - do mesmo período.

Mario Schenberg conclui a apresentação da sala especial mencionando a formação do pintor, autodidata por excelência, isolada das tendências artísticas de então (primeiro tempo Modernista: décadas de 20 e 30). Apesar de ter podido, nos anos de 1950, viajar à Europa e aprimorar seu aprendizado, tendo conhecido os primitivos italianos que tanto o impressionaram, e de ter sido depois influenciado pelo concretismo, o sentimento popular não deixou Volpi: seus ecos estavam presentes nas hoje famosas bandeirinhas dos anos de 1950 e 1960.

É importante notar que a sala especial organizada por Mario Schenberg teve repercussão favorável na imprensa, na medida em que apresentou com eficiência e caráter didático todas as fases de Alfredo Volpi até aquele momento. Mesmo entre os visitantes estrangeiros, a mostra foi bem vista ${ }^{137}$. Outro aspecto positivo apontado é a abundância de documentação da pesquisa empreendida por Volpi, que permite ao visitante compreender o peso de seu trabalho na visa artística do país ${ }^{138}$.

Interessa destacar, cinco anos após a VI Bienal, o que noticia o jornal Correio

\section{Paulistano:}

\footnotetext{
${ }^{136}$ SCHENBERG, Mario. Alfredo Volpi. In FUNDAÇÃO BIENAL. VI Bienal. (catálogo de xposição) São Paulo: Fundação Bienal, 1961, p. 38.

${ }^{137}$ Pintura, Desenho e Opiniões. Correio Paulistano, São Paulo (capital), 22 dez. 1961.

${ }^{138}$ MARTINS, Vera. Roteiro da Bienal. Jornal do Brasil, 27 ago. 1961.
} 
Numerosos colecionadores, brasileiros e estrangeiros, de passagem por São Paulo, têm procurado Alfredo Volpi no atelier, no Cambuci, para adquirir trabalhos seus. Os primeiros compraram. Os demais não encontraram mais o que comprar, pois o mestre vendeu tudo o que tinha, já em consequência de seu nome ter se firmado em todo o território brasileiro, já graças ao efeito positivo de sua sala especial na Bienal, carinhosamente montada, dizem, pelo matemático Mario Schenberg, que é um dos grandes colecionadores paulistas ${ }^{139}$.

Para o pintor, certamente essa projeção foi um grande incentivo, tanto artístico, quanto financeiro, à continuidade de sua pesquisa por meio de seus trabalhos. Nesse sentido, percebem-se as consequências positivas do trabalho de Mario Schenberg, enquanto crítico de arte pelos artistas dos quais se aproximava.

É bastante provável que o crítico tenha tido muita independência nessa tarefa, ainda que contando com a colaboração de Mário Pedrosa na organização da Sala Especial, uma vez que este ocupava, então, a direção geral da Bienal do Museu de Arte Moderna de $1961^{140}$. Importa observar que, nesse contexto, a obra de Alfredo Volpi reunia elementos do construtivismo, tão caro a Mário Pedrosa, e a parcela ligada ao primitivo e à arte popular, evidenciada por Mario Schenberg ${ }^{141}$. Vê-se, então, uma aproximação desses dois críticos em torno dessa questão, bem como do projeto das bienais.

Com relação ao motivo pelo qual Mario Schenberg teria sido convidado a fazer parte da organização do certame, num primeiro momento, coloca-se a escolha feita pelo próprio Volpi, quando consultado por Mario Pedrosa. Tendo em vista um quadro mais amplo, contudo, a contribuição da artista Maria Bonomi (2018) ${ }^{142}$ permitiu aquilatar novos aspectos da aproximação entre Mario Schenberg e a bienal. Com base no convívio que teve com Ciccillo Matarazzo, a artista relata que o empresário tinha uma percepção bastante abrangente do meio cultural e sabia que Mario Schenberg teria muito a oferecer às bienais. Nesse sentido, o crítico foi convidado com intenções muito claras:

\footnotetext{
${ }^{139}$ Correio Paulistano, São Paulo (capital), 10 dez. 1966.

140 [Informação verbal] MAGALHÃES, Fábio. Entrevista concedida a Ana Paula Cattai Pismel. São Paulo, 05 abr. 2018. 12 arquivos .MOV (1h52'22''). [A entrevista encontra-se depositada no Centro Mario Schenberg de Documentação da Pesquisa em Arte - ECA/USP]

141 [Informação verbal] BONOMI, Maria. Entrevista concedida a Ana Paula Cattai Pismel. São Paulo, 16 mai. 2018. 4 arquivos .mp3 (1h46'15')'. [A entrevista encontra-se depositada no Centro Mario Schenberg de Documentação da Pesquisa em Arte - ECA/USP]

142 [Informação verbal] BONOMI, Maria. Entrevista concedida a Ana Paula Cattai Pismel. São Paulo, 16 mai. 2018. 4 arquivos .mp3 (1h46'15'). [A entrevista encontra-se depositada no Centro Mario Schenberg de Documentação da Pesquisa em Arte - ECA/USP]
} 
primeiramente, por conta de sua proximidade com os artistas e seu interesse pela arte e, em segundo lugar, por sua capacidade de trazer um novo olhar para com as obras de arte, que poderia agregar a singularidade da figura de Mario Schenberg ao quadro da bienal. Nesse contexto, Ciccillo Matarazzo tinha a intenção de atualizar o debate que havia no certame, além de contar com o peso que o reconhecimento internacional da carreira científica de Schenberg agregava ao seu nome.

Apesar de manter em sua pessoa o controle da Bienal, o empresário soube reunir os maiores nomes nacionais e estrangeiros para atuar na organização da mostra nas décadas de 1950 e 1960. A tais pessoas, envolvidas com o debate artístico, Ciccillo era capaz de transferir o poder de decisão acerca das escolhas necessárias para fazer as bienais acontecerem. Ciccillo Matarazzo defendeu a presença de Mario Schenberg na bienal, mesmo diante dos questionamentos a respeito do posicionamento ideológico do crítico. Contudo, o que importava para Ciccillo era sua contribuição diferenciada enquanto crítico de arte, independentemente de questões políticas.

Mario Schenberg, por sua vez, também respeitava muito o mecenas que tomava para si o encargo de realizar as bienais, pois admirava o empresário, bem como sua atitude em prol da arte e da cultura do país. Para o crítico, Ciccillo era um pioneiro, alguém que estava fazendo algo para construir o país, mesmo com os diversos riscos que isso acarretava. Pode-se dizer que Mario Schenberg e Ciccillo Matarazzo se comprometeram em torno da questão da bienal, dado que, para o certame, era importante contar com o crítico; ao passo que, para Schenberg, o espaço a ele garantido e a liberdade com que poderia atuar eram extremamente importantes. 
Figura 12: Alfredo Volpi, [Vista de Itanhaém] [Marinha de Itanhaém], década de 1940, têmpera sobre tela, 45 x $76 \mathrm{~cm}$. Coleção Particular. Reprodução fotográfica de autoria desconhecida.

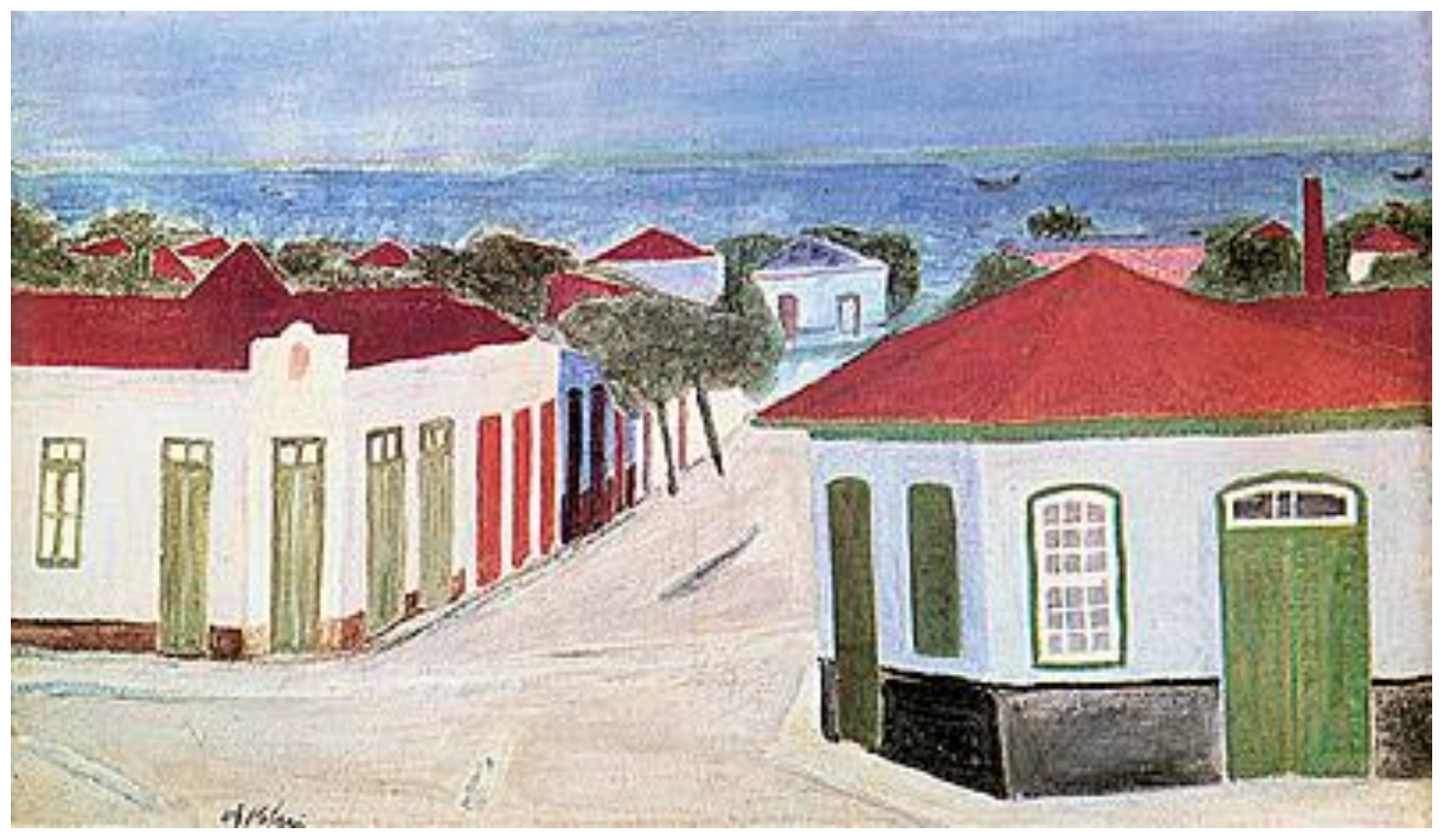

Fonte: [VISTA de Itanhaém] [Marinha de Itanhaém]. In: ENCICLOPÉDIA Itaú Cultural de Arte e Cultura Brasileiras. São Paulo: Itaú Cultural, 2018. Disponível em: <http://enciclopedia.itaucultural.org.br/obra2809/vista-de-itanhaem-marinha-de-itanhaem>. Acesso em: 26 de Fev. 2018. Verbete da Enciclopédia. ISBN: 978-85-7979-060-7

Figura 11: Alfredo Volpi, [Composição com Faixas], déc. 1960, têmpera sobre tela, 75 x 110,3 $\mathrm{cm}$. Coleção Particular. Reprodução fotográfica Horst Merkel.

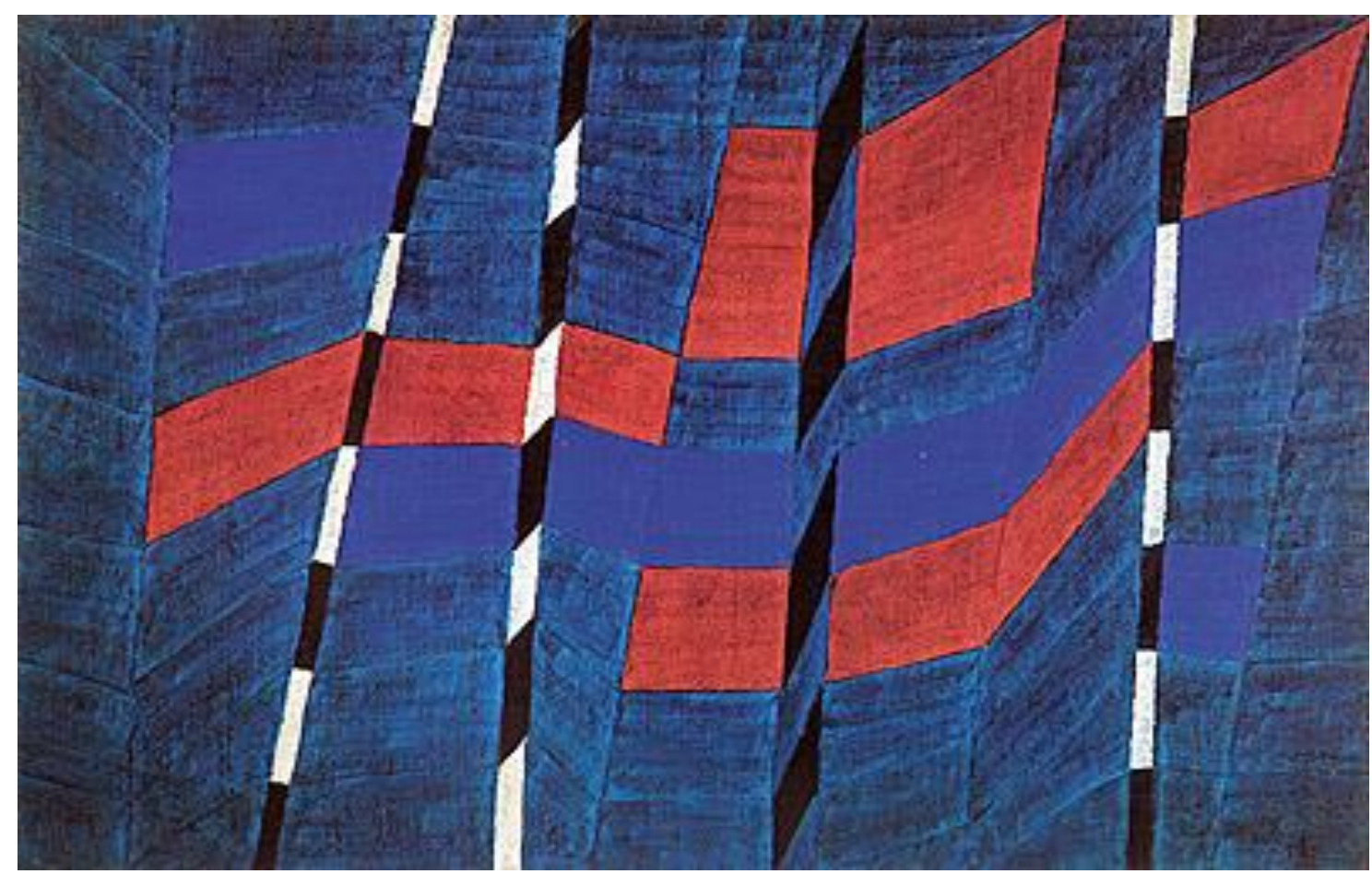

Fonte: [COMPOSIÇÃO com Faixas]. In: ENCICLOPÉDIA Itaú Cultural de Arte e Cultura Brasileiras. São Paulo: Itaú Cultural, 2018. Disponível em:

<http://enciclopedia.itaucultural.org.br/obra1798/composicao-com-faixas>. Acesso em: 26 de Fev. 2018. Verbete da Enciclopédia. ISBN: 978-85-7979-060-7 
Figura 13: Alfredo Volpi, Fachada com Bandeiras, 1959, Têmpera sobre tela, 116 x $72 \mathrm{~cm}$. Acervo do Museu de Arte de São Paulo - MASP, doação de Ernest Wolf. Reprodução fotográfica: João Musa.
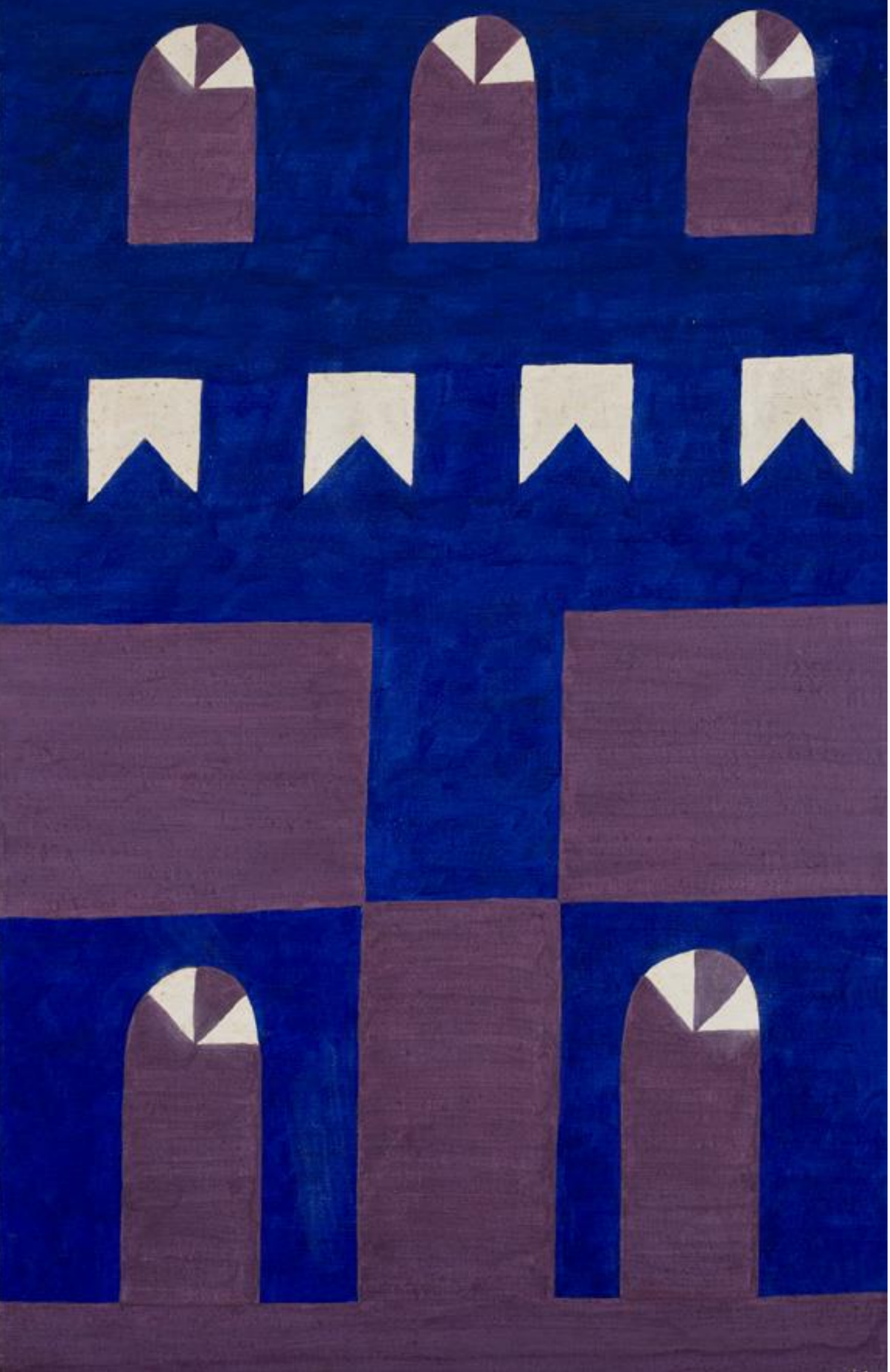

Fonte: disponível em: 〈https://masp.org.br/acervo/obra/fachada-com-bandeiras〉 Acesso em 25 fev. 2018. 
Figura 14 - Vista externa com outdoor da VI Bienal de São Paulo. Autoria desconhecida.

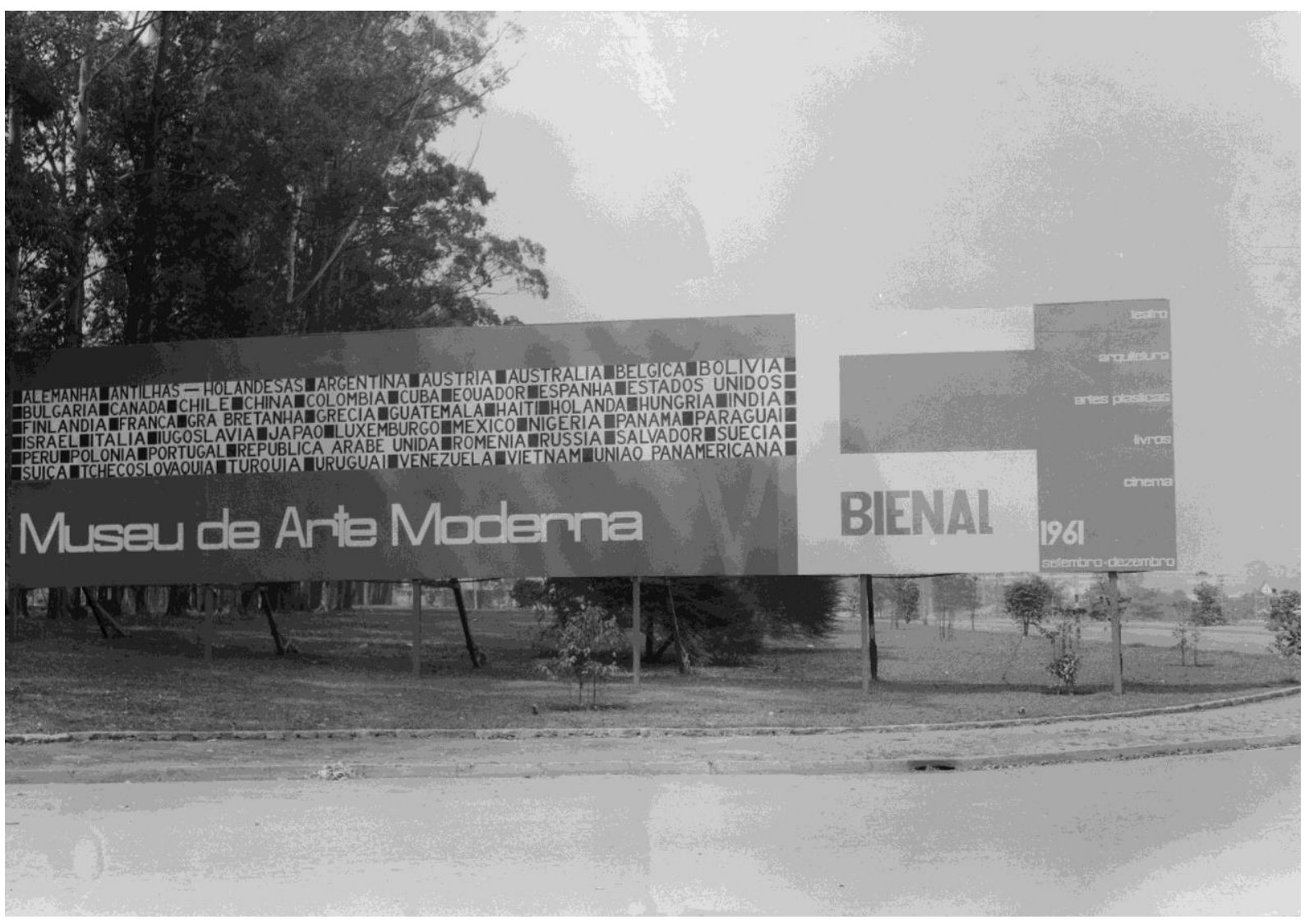

Fonte: Arquivo Histórico Wanda Svevo/Fundação Bienal. 


\section{Júri de Seleção: em defesa dos artistas}

Disse-me um dia: "Vivemos juntos. No Egito.
Uma vida antiga, Sabias?"

Não.

E falávamos de possíveis universos

Das infinitas matérias. Ele dizia:

"Não contes a ninguém... mas acredito

Acredito, acredito."

Hospedou-se em minha casa Quando o perseguiam. Às vezes saía à noite:

Chapéu, charuto, casaco. Ríamos

Dos disfarces absurdos: tão ele.

Todos o reconheciam.

Juntos inauguramos

Um ciclo de palestras na Unicamp:

Física. Poesia. Rigor. Magia.

Amado Mário. Lúcido ao infinito.

Veemente, Humilde.

Igual a todos os gigantes.

No silêncio é que nos entendíamos. ${ }^{143}$

Hilda Hilst

A atividade de Mario Schenberg junto aos artistas era tão grande que circulava até uma anedota nos meios artísticos de São Paulo. Favava-se de um artista tão desconhecido, mas tão desconhecido, que nem o próprio Mario Schenberg o conhecia ${ }^{144}$

Jos Luyten

${ }^{143}$ HILST, Hilda. Da Poesia. $1^{\text {a }}$ edição. São Paulo: Companhia das Letras, 2017, pp, 526-527. Sobre isso, Hilda Hilst comentaria, anos mais tarde, em entrevista: "Fui, junto com o Mario Schenberg, dar uma aula inaugural na UNICAMP. Mario achava que nós, eu e ele, havíamos nascido no Egito, que eu havia sido uma sacerdotisa amiga dele. É claro que ele não falava dessas coisas na universidade. "Tenho medo de perder o meu emprego", ele dizia. [...] Ele [Mario Schenberg] era um homem maravilhoso, capaz de explicar pra gente as teorias do Einstein com muita simplicidade. Não tinha orgulho nenhum, era muito humilde, muito simpático. Foi um grande amigo cuja perda me deixou muito triste. Há até um poema que eu fiz pra ele e que foi publicado em algum lugar." (HILST, Hilda. Fico besta quando me entendem: entrevistas com Hilda Hilst. Cristiano Diniz (org.) São Paulo: Globo, 2013, p. 224). O poema a que a poetisa se refere é "Mario Schenberg: amado alguém", que havia sido publicado pela primeira vez na Revista da USP, São Paulo, nº 9, p. 115, mar./abr./maio 1991.

${ }^{144}$ LUYTEN, Jos. Mario Schenberg, amigo dos artistas. Jornal A Gazeta. São Paulo, 10 jun. 1972, pág. 9. 
Para Mario Schenberg, cuja esfera de atuação orbitava entre sua atividade acadêmica como docente na então FFCL (Faculdade de Filosofia, Ciências e Letras da USP), a militância política e a crítica de arte, o ano de 1965 foi bastante intenso e repleto de acontecimentos marcantes. Exposições significativas tiveram lugar nesse ano: Opinião 65, no Museu de Arte Moderna do Rio de Janeiro, e Propostas 65, na Fundação Armando Álvares Penteado ${ }^{145}$. Todas contaram, em maior ou menor medida, com a sua participação.

Comunista assumido ${ }^{146}$, Mario Schenberg também teve que lidar com a perseguição política. As complicações decorrentes do momento político de então - a deflagração do Golpe Militar de 1964 - prejudicaram também o exercício de suas atividades enquanto pesquisador e docente na Universidade de São Paulo. Único convidado latino-americano para um importante congresso no Japão, Mario Schenberg só conseguiu participar do evento por causa da repercussão internacional de sua prisão, pois seu status de renomado cientista projetou internacionalmente a arbitrariedade do regime militar instaurado no país.

Nesse momento de agitação política e cultural, Mario Schenberg voltou a se envolver com a organização das bienais, dessa vez como membro do Júri Nacional de Seleção. Participou, assim, da organização da VIII, IX e X bienais de Arte de São Paulo (em 1965, 1967 e 1969), eleito pelos próprios artistas (AGUILAR, 1996).

A VIII Bienal de Arte de São Paulo, formalmente desvinculada do Museu de Arte Moderna, esteve aberta entre 4 e 28 de novembro de 1965. A mostra foi organizada pelas assessorias de artes plásticas (Geraldo Ferraz, Sérgio Milliet e Walter Zanini), teatro (Aldo Calvo e Sábato Magaldi), arquitetura (Oswaldo Corrêa Gonçalves) e artes gráficas (Jannar Murtinho Ribeiro). Em seus quase três meses de duração, foram apresentados ao público 653 artistas de 54 países, totalizando 4.054 obras $^{147}$.

\footnotetext{
${ }^{145}$ A participação de Schenberg nessas duas exposições, além de Opinião 66 e Propostas 66, foi explorada em PISMEL, Ana Paula Cattai. Schenberg: em busca de um Novo Humanismo. São Paulo: Programa de Pós-Graduação Interunidades em Estética e História da Arte, Universidade de São Paulo, 2013 (dissertação de mestrado).

${ }^{146}$ Na década de 1960, Mario Schenberg foi membro titular do Comitê Central do Partido Comunista. Cf. Dina Kinoshita. A Política para Mario Schenberg, s.p. (texto digitado - Arquivo do Centro Mario Schenberg de Documentação da Pesquisa em Artes - ECA/USP).

${ }^{147}$ FUNDAÇÃO BIENAL. Bienal a Bienal. Disponível em:
} 
Nessa edição já era possível perceber que mudanças profundas ocorreriam na arte, o que apareceria com mais força na IX Bienal. A Pop Art já despontava como tendência emergente, assim como a Arte Povera (que trabalhava com sucata, refugos e materiais semelhantes) e a quebra dos suportes tradicionais. Para Leonor Amarante, a mostra estava bem distribuída, abrigando as novas figurações, concretismo, surrealismo e arte fantástica ${ }^{148}$.

A sala especial internacional "Do Surrealismo à Arte Fantástica", de caráter histórico, foi o destaque da VIII Bienal, e teve um catálogo à parte, rico em imagens das obras exibidas. Nela figuraram sessenta artistas, entre os quais estavam Marcel Duchamp, Max Ernest, Jean Arp, Marcel Chagal, Joan Miró, Man Ray, Paul Klee, Magritte, Francis Picábia e Frida Kahlo.

A sexta edição da Bienal de São Paulo ficou conhecida, também, pela destacada presença do neoconcretismo brasileiro, tendência à qual pertenciam os Bichos de Lygia Clark, que recebeu o prêmio de escultura. Note-se que a artista havia exposto, em 1959, na V Bienal, o conjunto intitulado Planos em Superfície Modulada - Série B (1959). Sobre a premiação da artista, Ferreira Gullar opinou que convinha destacar seu significado especial por duas razões: a primeira dizia respeito à importância do reconhecimento internacional conferido a um trabalho que, até poucos meses antes, dividia opiniões. O segundo motivo vinha do fato de que estavam sendo premiadas como escultura obras que estavam "fora de qualquer definição coerente desse gênero de arte" 149 .

O abstracionismo concreto estava representado pela figura de Alfredo Volpi, cuja sala especial fora organizada por Mario Schenberg. Outros nomes relevantes foram Willys de Castro, Amilcar de Castro e Ivan Serpa, além de Anatol Wladyslaw, que recebeu o prêmio de desenho, e Iberê Camargo, que ficou com o de Pintura. Assinalese que Mario Schenberg manteve proximidade tanto com Lygia Clark quanto com Alfredo Volpi, escrevendo sobre eles, além dos demais artistas mencionados.

$\langle$ http://www.bienal.org.br/FBSP/pt/AHWS/BienalaBienal/Paginas/6BienalSaoPaulo.aspx?selected=6 . Acesso em 15 jan. 2013.

${ }_{148}$ AMARANTE, Leonor. As Bienais de São Paulo: 1951 a 1987. São Paulo: Projeto, 1989.

${ }^{149}$ GULLAR, Ferreira. Não objeto prêmio da Bienal - Lygia Clark. Jornal do Brasil, 16 e 17 set. 1961. 
Figura 15 - Planos em Superfície Modulada Série B (1958), de Lygia Clark, na 5ª Bienal (1959). Autor desconhecido.

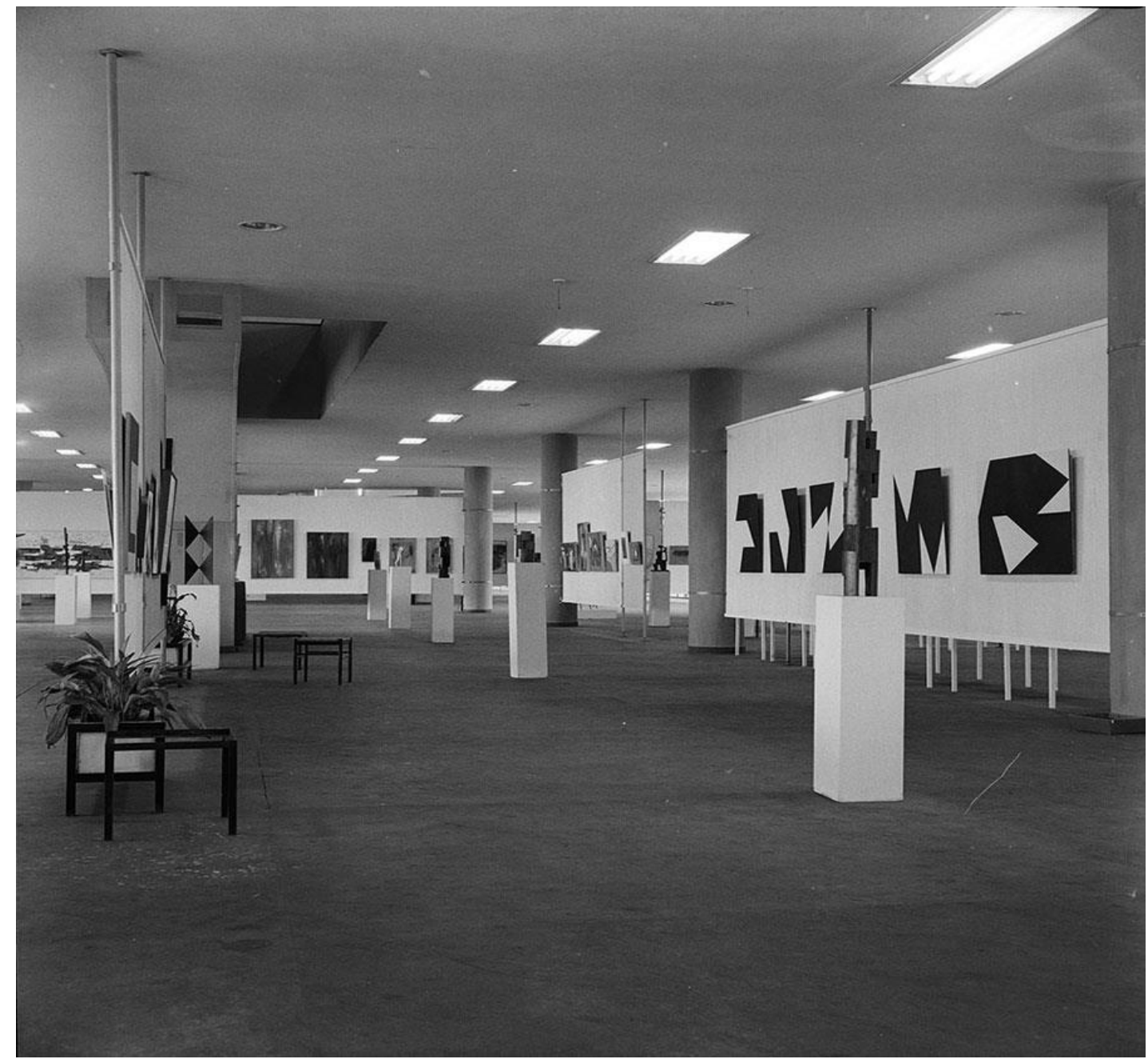

Fonte: FUNDAÇÃO BIENAL DE SÃO PAULO. Hoje e antes. Um paralelo entre imagens das obras na mostra $30 \times$ Bienal e seus primeiros registros nas Bienais passadas. Disponível em: 〈http://www.bienal.org.br/post/263〉. Acesso em 12 jun. 2018. 
Figura 16 - Lygia Clark, séries Bichos e Superfícies, em Sala Especial da $7^{\text {a }}$ Bienal. (C) Athayde de Barros.

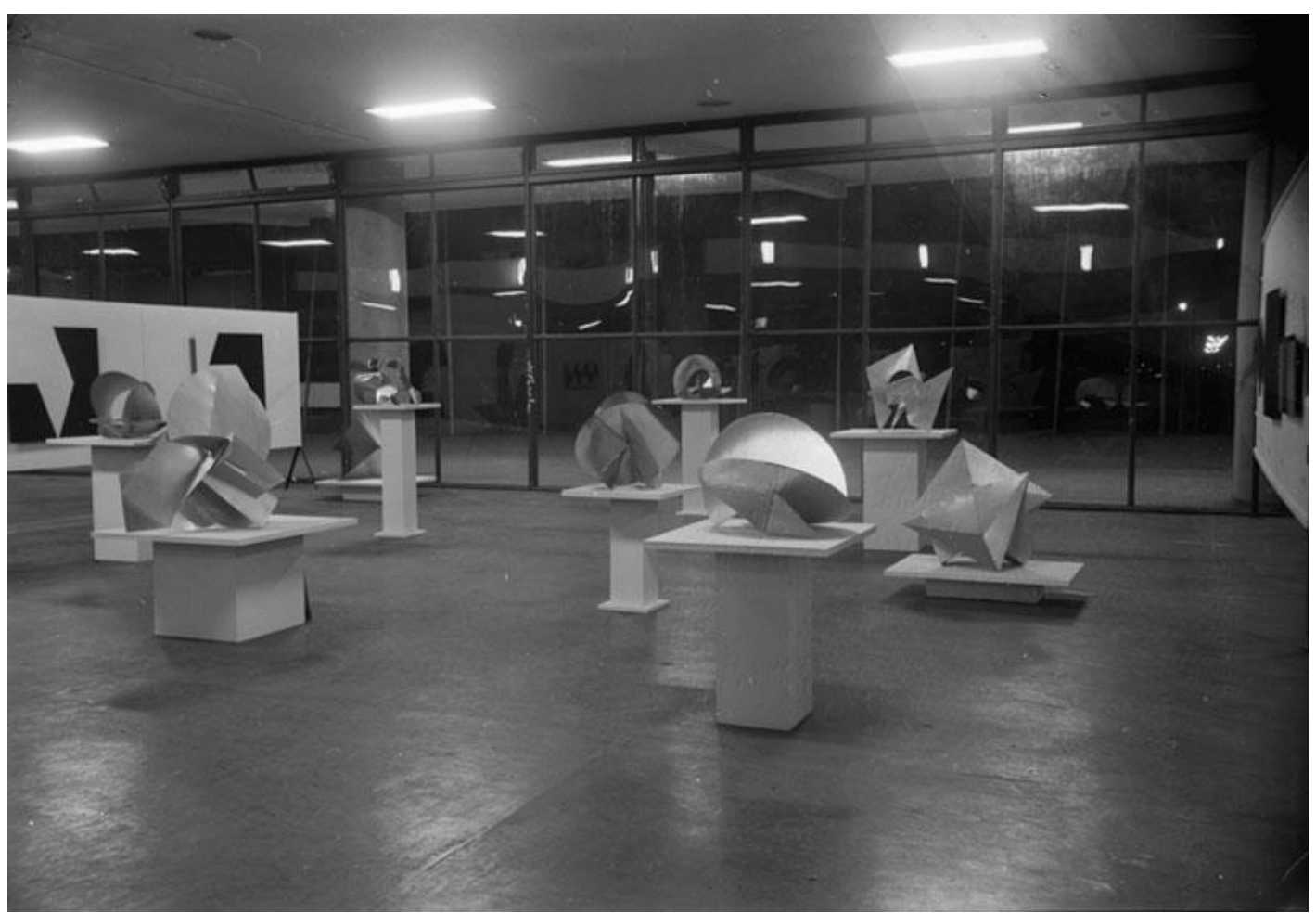

Fonte: FUNDAÇÃO BIENAL DE SÃO PAULO. $7^{\mathbf{a}}$ Bienal de São Paulo. Disponível em: $<$ http://www.bienal.org.br/exposicoes/7bienal/fotos/3871〉. Acesso em: 11 jun. 2018. 
Figura 17 - Vão central da $8^{a}$ Bienal com vista para pinturas de Danilo di Prete. À direita, Rogelio Polesello, Caleidoscopio [Caleidoscópio]. (C) Athayde de Barros.

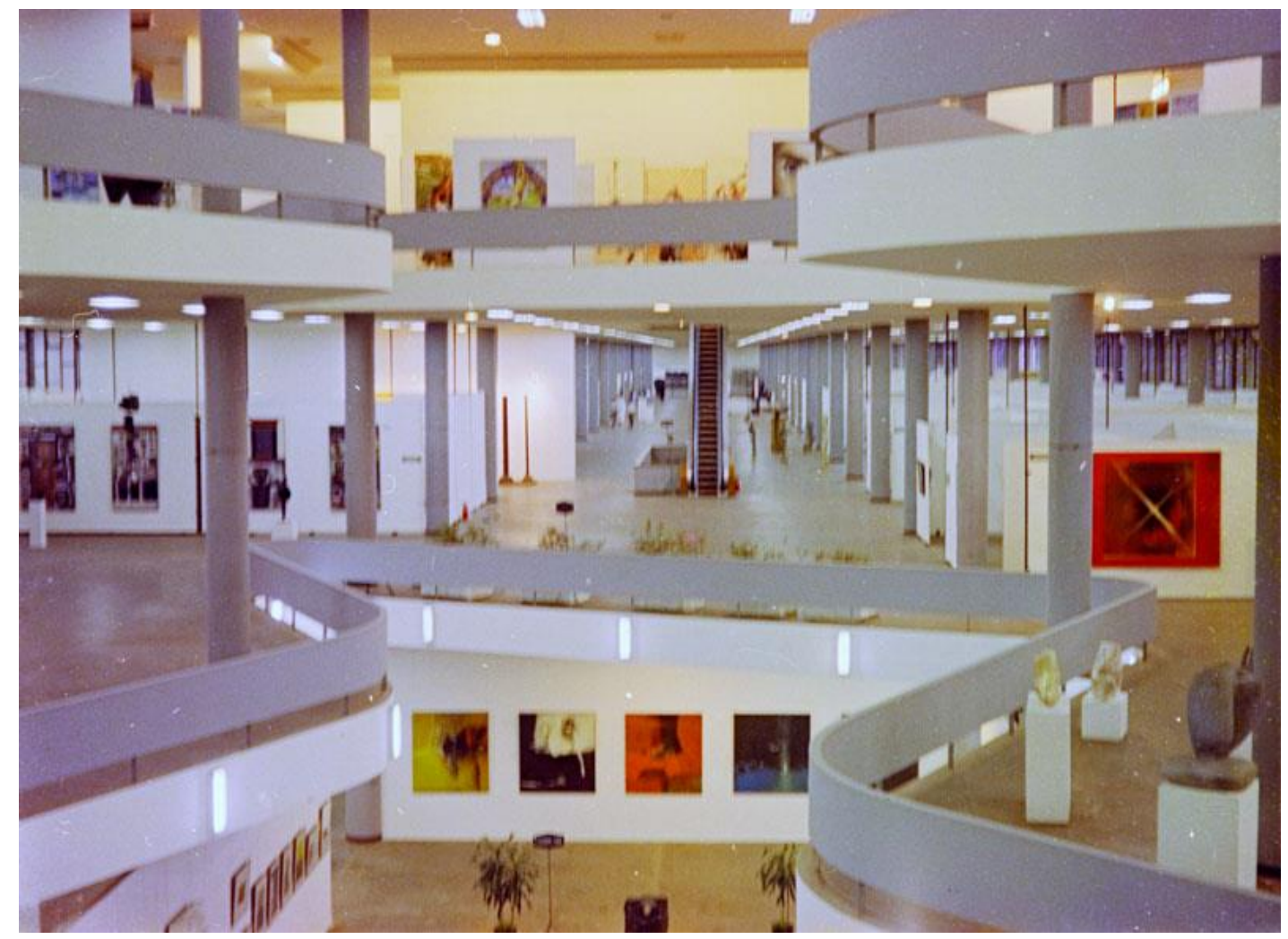

Fonte: FUnDAÇÃO BIENAL DE SÃO PAULO. $8^{\mathbf{a}}$ Bienal de São Paulo. Disponível em: <http://www.bienal.org.br/exposicoes/8bienal/fotos/3878>. Acesso em: 11 jun. 2018. 
Já a representação brasileira, apesar de ter recusado $80 \%$ dos artistas submetidos ao Júri de Seleção (superando as bienais anteriores) ${ }^{150}$, era bem maior que as estrangeiras, como ocorria desde sua primeira edição. O grande número de artistas recusados representava uma tentativa, por parte da Bienal, de elevar a qualidade da representação brasileira e, ao mesmo tempo, reduzir suas dimensões. Esses dois aspectos organizacionais vinham sofrendo ataques por parte de artistas e críticos de arte.

Enquanto os artistas criticavam a falta de critérios de avaliação que transparecia nas escolhas do Júri de Seleção, o alvo dos críticos de arte, embora com diferenças de opinião, era o inchaço da representação brasileira, que aceitava artistas que não estavam à altura da Bienal e parecia não saber separar o joio do trigo.

Contudo, era fato conhecido que, nas condições oferecidas ao corpo de jurados, apesar da boa vontade com que desenvolviam os trabalhos de seleção, era impossível se chegar a decisões totalmente acertadas. Paulo Mendes de Almeida reconhece que o veredito do Júri é "frequentemente injusto, por mais isento que seja, embora animado dos melhores propósitos", conforme acreditava ser o caso da VIII Bienal. O crítico acrescenta ainda: "[v]endo quatrocentas obras, em média, por dia, que critério, que metro, que medida de relação podem observar os membros desse colégio"?151

A isso era atribuída a falta de unidade da representação brasileira, ressaltada por Aracy Amaral, que a comparava a um salão, no qual havia de tudo um pouco, "como se o Brasil tivesse a preocupação de mostrar que pode apresentar de tudo para todos os gostos"152. Assim, o conjunto brasileiro, constituído por grande número de artistas, cada um com poucas obras, tornava-se confuso e assemelhava-se a uma feira de arte. Segundo a autora, essa estrutura já estava superada e precisava ser revista pela Fundação Bienal $^{153}$.

A mostra abria as portas ao grande público um ano e meio depois do golpe militar de 1964. Apesar de a censura ter sido mais intensa a partir de 1968, em decorrência do Ato Institucional $n^{\circ} 5^{154}$, a repressão já começava a fazer parte do horizonte cultural e político do país. Repercutindo imediatamente na estrutura de poder da Universidade de

\footnotetext{
${ }^{150} \mathrm{O}$ corte foi duro, registrado o maior índice de recusa de todas as bienais: $80 \%$ dos inscritos foram recusados. Correio da Manhã (Estado da Guanabara), 19 mai. 1965.

${ }^{151}$ ALMEIDA, Paulo Mendes de. A próxima Bienal. O Estado de São Paulo, 26 jun. 1965.

${ }^{152}$ AMARAL, Aracy. Revisão da VIII Bienal. O Estado de São Paulo, 11 dez. 1965.

${ }^{153}$ AMARAL, Aracy. Revisão da VIII Bienal. O Estado de São Paulo, 11 dez. 1965.

${ }^{154}$ SCHWARZ, Roberto. Cultura e Política, 1964-69. In O Pai de Família e outros estudos. Rio de Janeiro: Paz e Terra, 1978.
} 
São Paulo, foi no ambiente acadêmico que a perseguição política atingiu Mario Schenberg.

Cabe assinalar que, no momento em que foi instaurado o Regime Militar, as universidades se tornaram um alvo estratégico, atraindo a atenção dos militares pois, em sua visão, "as universidades haviam se tornado ninhos de proselitismo das propostas revolucionárias e de recrutamento de quadros para as esquerdas" (MOTTA, 2014, p. 23). Dado o caráter anticomunista do Golpe de 1964, não é difícil perceber que, para ele, o "perigo de que o Brasil deveria ser salvo", a "ameaça comunista", residiria nas universidades (MOTTA, 2014) ${ }^{155}$.

A configuração dos ambientes acadêmicos, como o historiador Rodrigo P. Motta de Sá aponta no livro As Universidades e o Regime Militar ${ }^{156}$, pode dar a ver o motivo pelo qual houve tamanha perseguição: “[n]o início dos anos de 1960, a UNE (União Nacional dos Estudantes) era uma instituição influente no debate político, sobretudo no período do governo Goulart [...]” (p. 24). Além disso, os estudantes universitários eram, nesse período, um grupo muito receptivo às ideias das diversas esquerdas. Quanto aos docentes das grandes universidades, apesar de, em sua grande maioria, serem pouco receptivos a essas ideias, havia entre eles os que se posicionavam à esquerda, alguns até com militância no PCB, ativa ou pregressa. Já entre os docentes mais jovens, entre os vinte e trinta anos, embora fossem poucos, prevalecia a afinidade com "os ideais do movimento estudantil, do qual, aliás, eram egressos" (MOTTA, 2014, p. 25) ${ }^{157}$.

Nesse contexto, o eminente físico foi preso durante a primeira operação militar efetuada após o golpe, denominada "Operação Limpeza", cujo intuito "era 'limpar' o País da ameaça comunista, recolhendo todos aqueles que representassem uma ameaça à Segurança Nacional"158. O catedrático da USP e crítico de arte foi preso em 2 de abril de 1964, ou seja, um dia depois da consumação da tomada de poder pelos militares, que

\footnotetext{
${ }^{155}$ Segundo Motta (2014, p. 23), "Ali se encontraria um dos focos principais da ameaça comunista, o perigo iminente de que o Brasil deveria ser salvo, e que mobilizou muitos sobretudo nas corporações militares, a se levantar em armas contra o governo Goulart, acusado de tolerar ou, pior ainda, de se associar aos projetos revolucionários."

156 MOTTA, Rodrigo P. Sá. As universidades e o regime militar: cultura política brasileira e modernização autoritária. 1 $1^{\mathrm{a}}$ edição. Rio de Janeiro: Zahar, 2014.

157 "Sendo essa a situação nas universidades, sobretudo tendo em vista o perfil da militância estudantil, é fácil compreender por que elas foram tão visadas pela repressão. No momento do golpe, os agentes repressivos já tinham seus alvos previamente definidos. Eles mantiveram os militantes sob vigilância mesmo durante o período Goulart, quando a orientação em alguns estados e em âmbito federal era deixar a esquerda em paz." (MOTTA, 2014, p. 25).

${ }^{158}$ CLEMENTE, José Eduardo Ferraz. Ciência e política durante a ditadura militar: o caso da comunidade brasileira de físicos (1964-1979). Salvador: Universidade Federal da Bahia, Instituto de Física, 2005. (dissertação de Mestrado), p. 97.
} 
teve lugar em $1^{\circ}$ de abril do mesmo ano. Na ocasião em que se deu a prisão de Mario Schenberg, sua casa foi invadida e sua biblioteca, depredada. A documentação contida em seu prontuário no famigerado DOPS (Departamento de Ordem Política e Social) atesta apenas que o crítico teria sido "detido como medida de prevenção"159.

Sobre a ocasião, Julieta Bárbara relata que foi um momento difícil:

O Mario era vigiado dia e noite, tudo o que ele fazia, todos os passos que ele fazia, estão registrados ali. "O professor saiu tal hora, entrou tal hora, foi a Santos." [...]

Quando eu cheguei, a minha casa já estava aberta, estava cheia de polícia. Eles estavam procurando o "ouro de Moscou". [...] Eu ficava dia e noite pensando que iam levar o Mario para algum lugar. Quando chegava de madrugada, eu estava lá na porta do DOPS, porque diziam que iam levar ele não sei onde. Então, eu ficava lá vigiando, para saber se ele teria ido, se iria. Eu não deixava descanso. ${ }^{160}$

Logo depois, em 4 de abril, foi enviado à Justiça Militar o inquérito que buscaria dar suporte à sua prisão preventiva, com base em sua atividade no extinto $\mathrm{PCB}^{161}$. Nesse ínterim, contudo, teve lugar outro inquérito, que ficou conhecido como o caso das Cadernetas de Prestes ${ }^{162}$, no qual figuraram, além do nome de Mario Schenberg, cerca de 70 outros que constavam nas cadernetas de Luís Carlos Prestes, apreendidas em sua residência na cidade de São Paulo poucos dias depois, em 9 de abril. Nesse inquérito, o argumento incriminador era de que o crítico havia cometido um "crime em tese", apenas pelo fato de seu nome constar nas cadernetas. Mesmo diante disso, Schenberg foi posto em liberdade cerca de 50 dias depois.

\footnotetext{
${ }^{159}$ Prontuário de Mario Schenberg, $\mathrm{n}^{\circ}$ 89.583. Arquivo Geral do Departamento de Ordem Política e Social - DOPS. Arquivo do Estado de São Paulo.

${ }^{160}$ AGUILAR, José Roberto; MEIRELLES, Lucila; MARTIRANI, Pichi. Julieta é Bárbara. 2007, (25’). Disponível em: 〈https://www.youtube.com/watch?v=MxvN-adhGpk>. Acesso em: 3 mar. 2017. O depoimento acima foi transcrito do registro aqui referenciado, que se encontra hospedado no canal do artista José Roberto Aguilar. Julieta Bárbara foi esposa de Mario Schenberg.

${ }^{161}$ Schenberg foi preso anteriormente, em 1948, sob acusação de subversão à ordem pública, tendo sido liberado alguns meses depois. Logo após retornou à Europa, mais precisamente à Bélgica, onde permaneceu até 1953 (AGUILAR, José Roberto. O mundo de Mario Schenberg. São Paulo: Casa das Rosas, 1996).

${ }^{162}$ No dia 9 de abril de 1964, foram aprendidas pela polícia as cadernetas de Luís Carlos Prestes, pouco mais de uma semana após o movimento militar que depôs o presidente João Goulart. O material, pertencente ao então secretário-geral do PCB, líder dos comunistas brasileiros, foi encontrado numa casa da Vila Mariana, em São Paulo, na qual residia Maria, esposa de Prestes, juntamente com alguns filhos. Após o golpe, Maria teria deixado o local e militantes teriam retirado documentos da casa. Contudo, não se deram conta da presença das cadernetas e de outros documentos, que estavam escondidos sob roupas num armário. Além de Luís Carlos Prestes, que foi condenado a 14 anos de prisão à revelia, figuraram na lista de réus outros intelectuais, como o físico Mário Schenberg, e políticos, como Carlos Mariguella. O historiador Sérgio Buarque de Holanda foi uma das testemunhas de defesa dos acusados. Cf. Arquivos guardam cadernetas de Prestes. Folha de São Paulo, 8 abr. 2001. Disponível em:

<http://www1.folha.uol.com.br/fsp/brasil/fc0804200118.htm>. Acesso em: 13 nov. 2017.
} 
Durante a década de 1960, Schenberg encontrou entre os artistas o apoio que possibilitou sua atuação, mesmo sob os mandatos de prisão e a perseguição política de que foi alvo. Apesar de ter vivido entre a prisão e a ilegalidade em alguns momentos, o crítico se recusou ao exílio no exterior por não poder tirar passaporte ${ }^{163}$ e por causa de seu senso de cidadania ${ }^{164}$. No decorrer do período em que esteve foragido, contou com a acolhida de diversos artistas que o esconderam da polícia, como mostraram vários depoimentos. Entre eles, o de Lourdes Cedran ${ }^{165}$ :

Conheci o Mário na década de 60, num período de muita agitação política pós-64. [...] Houve muitas prisões. Na época em que lançaram o Manifesto dos 4 (Mário Schenberg, Leite Lopes, Cruz Costa e Florestan Fernandes) foi anunciada a prisão de Mário. Neste dia ele havia combinado de me encontrar num curso de arte que eu fazia numa escola na Rua Augusta. Ele chegou com o Mário Gruber, que estava com o pé quebrado. Apesar de estar com prisão decretada, ele entrou calmamente, e disse que fôssemos jantar juntos. Em verdade, fomos levá-lo para um esconderijo - a própria casa do Gruber. [...] Fui informada depois que o Mário já não se encontrava na casa do Gruber, mas sim na casa de outros amigos.

Um dos amigos em cuja casa Schenberg ficou hospedado foi José Eugênio Soares, mais conhecido como Jô Soares. Em 2017, foi publicada sua autobiografia, intitulada O Livro de Jô: uma autobiografia desautorizada ${ }^{166}$ (volume 1), em que deixou

\footnotetext{
${ }^{163}$ Sobre isso, Schenberg fala em entrevista: "Eu ia sair daqui e, então, pedi um passaporte. O que é curioso é que o Ministério da Justiça lá de Brasília deu, foi até rápida a autorização, mas a polícia começou a enrolar aqui em São Paulo. Eu deixei um despachante cuidar. [...] Se eu tivesse ido pessoalmente talvez tivesse conseguido, mas não estava com apetite para estar andando lá pelo DOPS, era capaz até deles me prenderem. Então, deixei um despachante e o tempo foi passando. Consegui uma pessoa que tinha acesso ao gabinete do Secretário de Segurança para ver o que estava acontecendo. A informação que essa pessoa teve é que realmente tinha chegado a autorização. Mas sabe como é, quem é punido por Ato Institucional não pode sair do Brasil sem autorização do Ministro da Justiça. O Ministro da Justiça despacha mais ou menos nesses termos assim: não havendo empecilhos legais, ele concorda que se dê. Então, aqui do Gabinete é que achavam esse negócio insuficiente, quer dizer, podia não haver empecilhos legais, mas podia ser politicamente inconveniente. Eu falei até com o Manoel Gonçalves Ferreira, que estava trabalhando no Ministério, e ele me disse que o Ministro da Justiça, quando despachava, já pensava em todos os aspectos, não era só o aspecto legal. Mas a polícia de fato é que não deu e eu não pude ir para a Europa. Só pude sair daqui em 72. Aí, eu mesmo fui cuidar da coisa diretamente e consegui arrancar lá o passaporte. Foi um trabalho infernal, mas consegui”. Cf. SCHENBERG, Mário. Mário Schenberg (depoimento, 1978). Rio de Janeiro, CPDOC, 2010, p. 41-42.

164 "Schenberg foi aposentado e - diferentemente da maioria dos cientistas que foram cassados pela ditadura dos militares - não saiu do Brasil. Ele tinha propostas para trabalhar em qualquer país do mundo, mas tinha uma enorme determinação de ficar no Brasil. Foi o típico caso que deu trabalho aos militares." (GOLDFARB. José Luis. José Luis Goldfarb. In AJZENBERG, Elza. In Shenberg: Arte e Ciência. São Paulo: ECA/USP, 1997, p.44).

${ }^{165}$ CEDRAN, Lourdes. Lourdes Cedran. In SCHENBERG, Mário. Mário Schenberg: Entre-Vistas. São Paulo: Perspectiva, 1984, pp. 66-8.

${ }^{166}$ SOARES, Jô. O Livro de Jô: uma biografia desautorizada. $1^{\text {a }}$ edição. São Paulo: Companhia das Letras, 2017.
} 
registrada a impressão que teve a respeito do período em que conviveu diariamente com Mario Schenberg. A pedido do ator Juca de Oliveira, que também fazia parte do Partido Comunista Brasileiro (então na ilegalidade), Jô Soares, muito ligado ao meio teatral e televisivo da época, aceitou esconder o crítico, e comentou sobre ele mesmo e sua primeira esposa, a atriz Theresa Austregésilo: "nós não tínhamos militância política, mas aceitamos acolher aquele homem do bem com grande prazer-embora estivéssemos morrendo de medo de que algo desse errado" (SOARES, 2017, p. 420).

E foi assim que, por quase três meses, Mario Schenberg teve como casa a antiga garagem da casa de Jô Soares, que havia sido transformada em escritório. Apesar de as pessoas que de vez em quando iam visitá-lo serem sempre respeitosas, chamando-o de professor, Jô e sua esposa criaram intimidade com ele: "para nós, ele sempre foi simplesmente o Mario - para todos os efeitos, para o público externo, ele era um tio que tinha vindo passar um tempo conosco" (SOARES, 2017, p. 420).

Apesar da gravidade do contexto, a narrativa de Jô Soares destaca dois episódios com bom humor. No primeiro, em certa ocasião, Schenberg teria cogitado tingir os cabelos e colocar maquiagem para poder sair à rua. Felizmente, o crítico não o fez, alertado por Thereza de que, mesmo assim, todos o reconheceriam. Frente ao possível resultado cômico de seu disfarce, Schenberg encontrava motivos para rir. No segundo episódio, o crítico queria sair para ver uma mulher que, segundo diziam, crescia em tamanho quando exposta à luz do sol. Vejamos o caso nas palavras do autor:

Como quase todo grande cientista, Mario Schenberg tinha um lado místico. Havia uma garota do Partido Comunista, com um nome de guerra, é claro, que fazia a comunicação dele com o mundo exterior. Um dia, nos disse ele que iria com ela até o bairro do Pacaembu. Nós perguntamos o que ia fazer lá, e Mario respondeu que ia a casa de uma senhora que crescia de tamanho todas as vezes que ficava sob a luz do sol. Eu disse a ele:

- O quê? Um grande físico como você está me dizendo que irá ver uma mulher que não pode sair de casa porque ela cresce à luz do sol? Ele respondeu ligeiramente irritado, sempre com os olhos semicerrados:

- Sim! Várias pessoas me dizem que isso acontece mesmo.

- E você acredita?

O Mario vacilou um pouco, deu umas baforadas no charuto e respondeu:

- Não sei, preciso ver...

Theresa e eu pressionamos ele a não ir. Era muito arriscado e, além de tudo, seria um vexame se fosse preso na casa de uma mulher que dizia aumentar de tamanho enquanto tomava sol e voltava a encolher na sombra... (SOARES, 2017, p. 421) 
É interessante observar, sobre esse relato, que deve ter sido difícil para Schenberg, acostumado à liberdade e ao cosmopolitismo, passar meses escondido, sem a possibilidade de sair das casas dos diversos amigos pelas quais passou nesse período. Mas, ainda que Jô Soares e sua esposa tenham impedido o crítico de sair e se expor ao risco de ser preso, quando de sua estadia na residência da poetisa Hilda Hilst, Schenberg arriscou sair em algumas ocasiões em que, felizmente, isso não ocorreu. No poema "Mario Schenberg: amado alguém”, Hilda Hilst mobiliza sua lembrança em relação aos disfarces do crítico: "Hospedou-se em minha casa / Quando o perseguiam. / Às vezes saía à noite: / Chapéu, charuto, casaco. Ríamos / Dos disfarces absurdos: tão ele. /Todos o reconheciam.” (HILST, 2017, p. 526-527) É possível que isso se deva ao fato de que a poetisa, que iniciou sua produção literária em São Paulo, se mudou para a cidade de Campinas (SP) em 1964, quando deu início à construção da Casa do Sol, sua famosa residência que hoje abriga o Instituto Hilda Hilst, para onde se transferiu no ano seguinte ${ }^{167}$. Foi onde o crítico se hospedou ${ }^{168}$.

${ }^{167}$ INSTITUTO HILDA HIST. Hilda e obra. Disponível em: 〈https://www.hildahilst.com.br/hilda〉. Acesso em 1 mai. 2017.

168 "A amizade de Hilda Hilst e Mario Schenberg começou na década de 1960, quando ele, perseguido pela Ditadura Militar, abrigou-se na Casa do Sol. 'O que eu sei é que antes disso eles se conheciam muito pouco. Mas a característica mais engraçada das conversas deles é que a Hilda parecia uma física. Ela se metia nessas coisas, filosofia, física, matemática', diz Leandro Esteves, jornalista que passou a frequentar a Casa na década de 1980. O interesse de Hilda pelos quantas, o de Schenberg pela arte e o de ambos pelas diferentes dimensões da vida e do universo selaram a cumplicidade." INSTITUTO HILDA HIST. Diálogos com Mario Schenberg. Disponível em: <https://www.hildahilst.com.br/blog/dialogos-commario-schemberg $>$. Acesso em 1 mai. 2017. 
Figura 18 - Hilda Hilst em frente aos portões da recém construída Casa do Sol. Década de

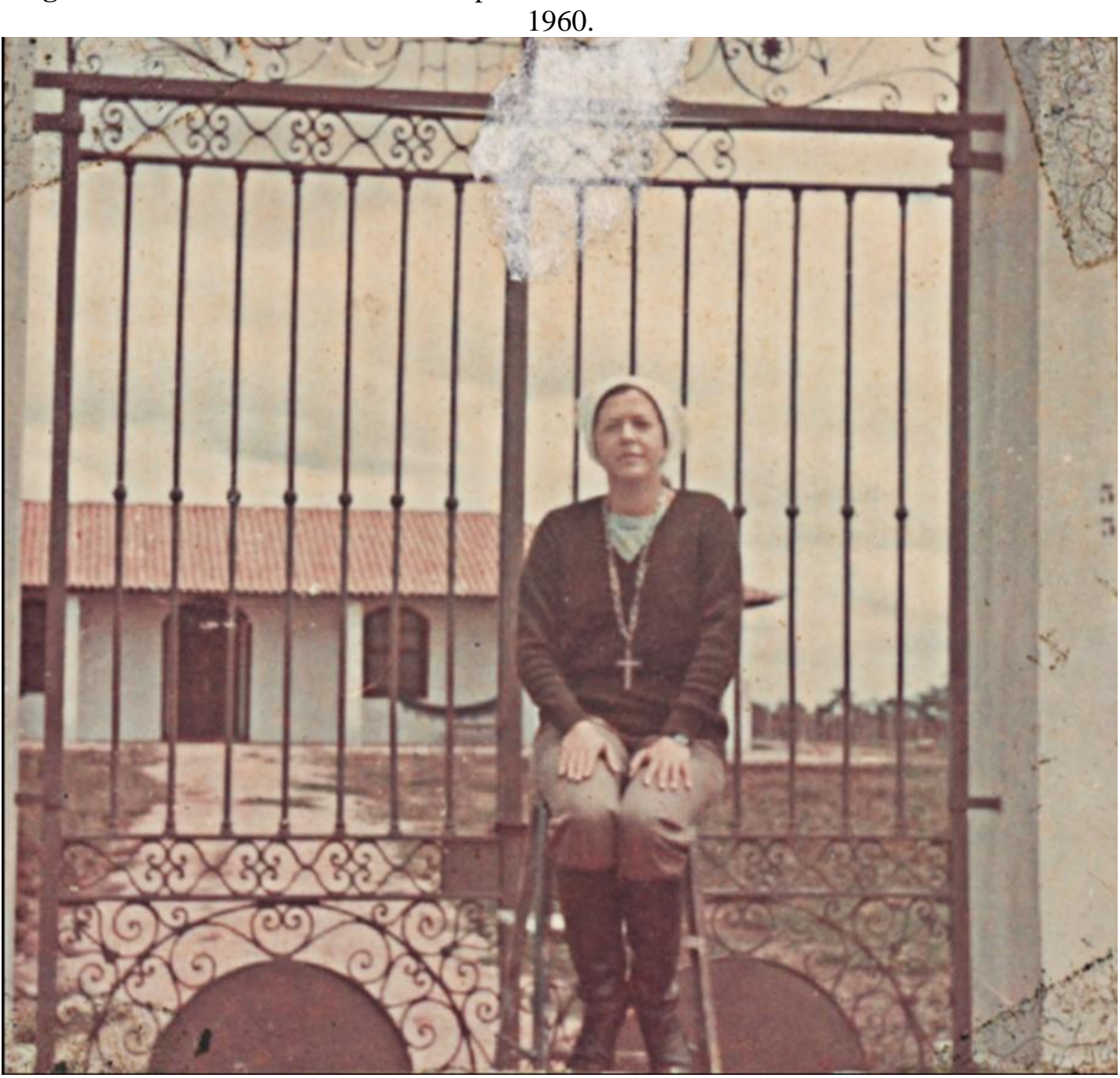

Fonte: Acervo Instituto Hilda Hilst. Foto: Jose Luis Mora Fuentes. 
Figura 19 - Hilda Hilst e Mario Schenberg. Década de 1960.

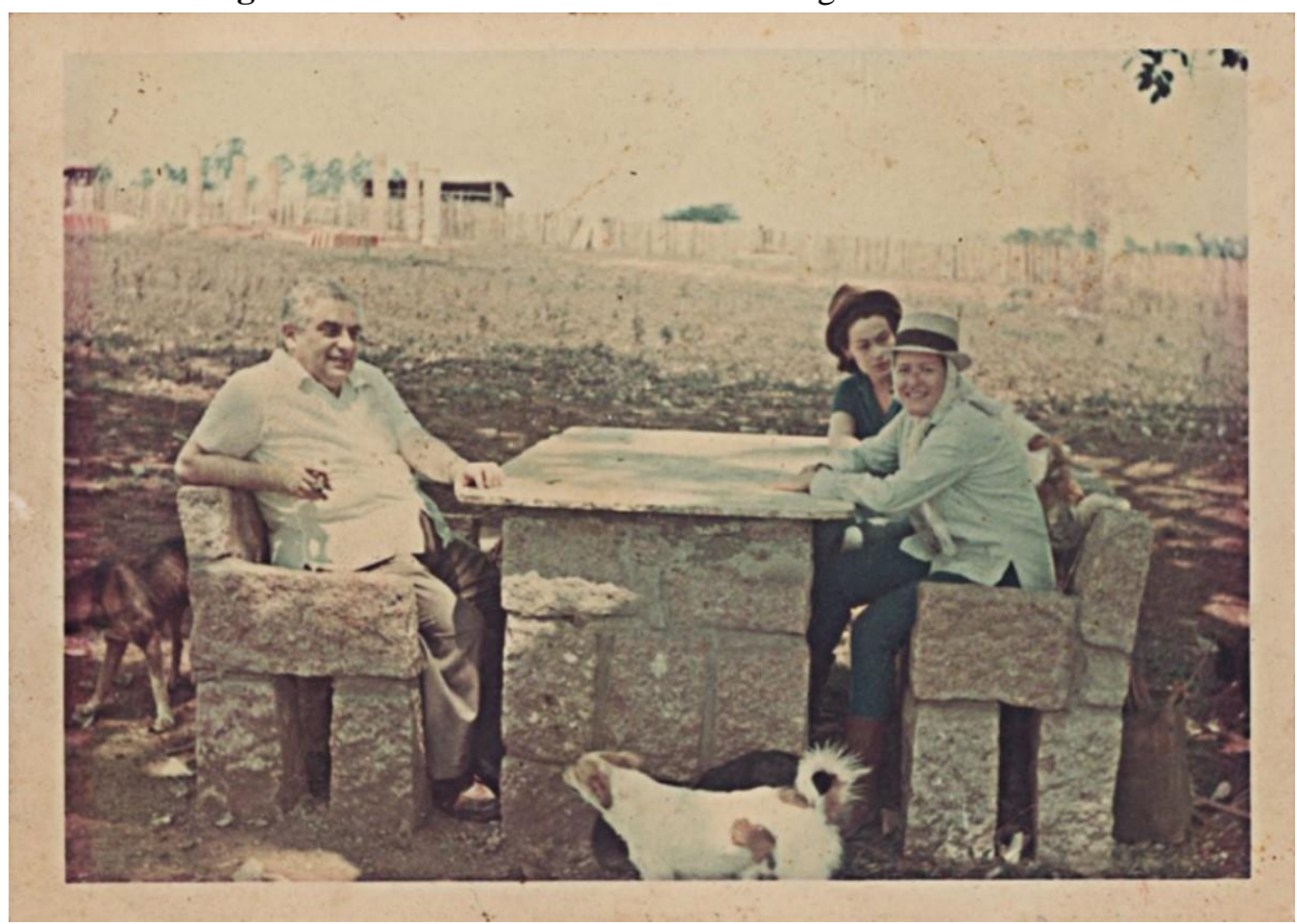

Fonte: Acervo Instituto Hilda Hilst. Foto: Autor não identificado.

Figura 20 - Mario Schenberg em frente à recém construída Casa do Sol, em 1965.

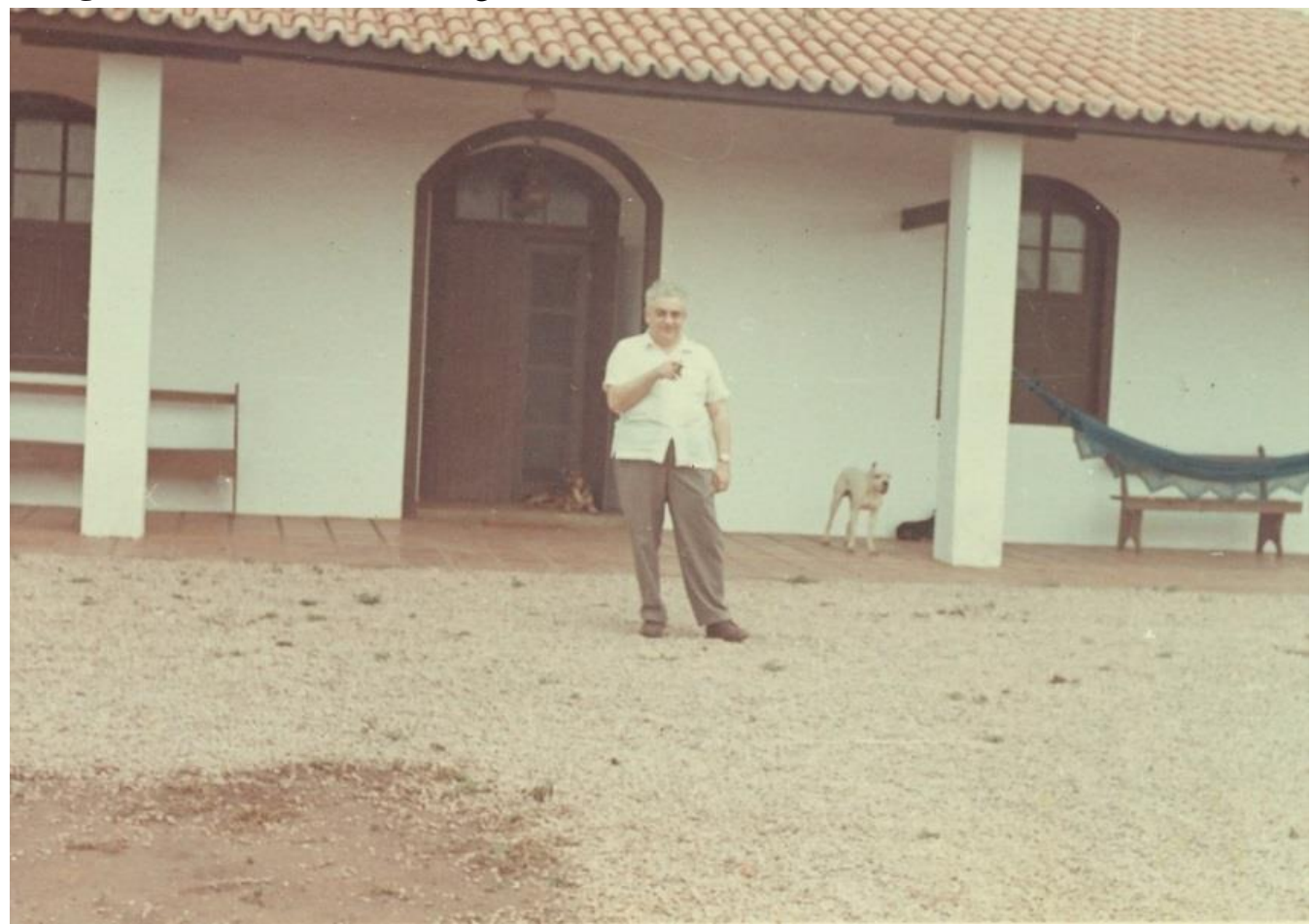

Fonte: Arquivo Histórico do Instituto de Física da USP. Foto: Autor não identificado. 
Não se pode deixar de assinalar, ainda, o elemento místico próprio da personalidade de Mario Schenberg, sempre disposto a explorar novos horizontes e a examinar novas ideias. Sabe-se que o crítico acreditava em vidas passadas e Hilda Hilst toca nesse ponto numa entrevista concedida na década de 1990. Segundo a poetisa,

\begin{abstract}
Mario achava que nós, eu e ele, havíamos nascido no Egito, que eu havia sido uma sacerdotisa amiga dele. É claro que ele não falava dessas coisas na universidade. "Tenho medo de perder o meu emprego", ele dizia. [...] Ele [Mario Schenberg] era um homem maravilhoso, capaz de explicar pra gente as teorias do Einstein com muita simplicidade. Não tinha orgulho nenhum, era muito humilde, muito simpático. [...] Há até um poema que eu fiz pra ele e que foi publicado em algum lugar." 169
\end{abstract}

É claro que o crítico sabia das fronteiras temáticas dos diferentes ambientes por onde transitava. Por isso, tinha em mente que, no plano acadêmico, dificilmente poderia esperar que sua vivência espiritual e sua reflexão acerca desse tema fossem levadas à sério. Fora das fronteiras da universidade, por outro lado, Schenberg se sentia à vontade para discutir todo tipo de assunto. Com relação a essa característica de Schenberg, Scarlett Marton observaria que o crítico era aberto e, "[s]empre com o mesmo entusiasmo, entretinha-se acerca dos mais variados assuntos; sem jamais desmerecer o que lhe era dito, conversava sobre os temas mais diversos" (MARTON, 2004, p. 155).

Apesar do humor contido em alguns dos relatos acima, esse momento não foi fácil para Schenberg. Após o golpe militar, que se deu entre 31 de março e $1^{\circ}$ de abril de 1964, o crítico teve sua casa invadida pela polícia, que revistou sua notável biblioteca em busca de supostas provas de subversão. Novamente, é Jô Soares quem relembra um episódio muito interessante, que deve ter ouvido do próprio Mario Schenberg quando estava em sua casa:

Na invasão da casa dele [de Mario Schenberg], logo depois do golpe, um dos delegados que comandaram a ação começou a olhar a sua valiosa biblioteca. Pegava os livros, dava uma olhada, depois os jogava no chão. Aí ele tirou da prateleira os Diálogos, de Platão. Folheou com o ar de quem tinha achado um documento importante e falou em tom severo para o Mario:

- E isso aqui? O que é?

- É Diálogos, de Platão.

${ }^{169}$ HILST, Hilda. Fico besta quando me entendem: entrevistas com Hilda Hilst. Cristiano Diniz (org.) São Paulo: Globo, 2013, p. 224. O poema a que a poetisa se refere é "Mario Schenberg: amado alguém”, que havia sido publicado pela primeira vez na Revista da USP, São Paulo, nº 9, p. 115, mar./abr./maio 1991. 
E o delegado:

- Sim, mas diálogos de Platão com quem?

O Mario se segurou para não rir.

- Este livro é subversivo. O senhor não é professor? Então isso o senhor vai nos revelar: com quem foram esses diálogos e qual era o assunto! (SOARES, 2017, p. 421) ${ }^{170}$

Segundo o historiador Rodrigo P. Motta de Sá aponta no livro As Universidades

e o Regime Militar ${ }^{171}$, essas práticas tinham sido parte de algumas operações de prisão efetuadas no momento e

geraram ótimas oportunidades de sátira política, uma das primeiras armas de ataque contra as forças de repressão, pois o humor era um dos poucos recursos à disposição [...]. Como os agentes da ordem nem sempre conseguiam identificar livros subversivos, às vezes apreendiam textos anódinos, apenas em razão da capa vermelha ou de um sobrenome estrangeiro. Com isso, ofereceram prato cheio ao talento de humoristas e chargistas da oposição, como Stanislaw Ponte Preta (pseudônimo de Sérgio Porto) e Jaguar, que não perderam a oportunidade para troçar da suposta falta de inteligência das forças de ordem. (MOTTA, 2014, p. 27) ${ }^{172}$

Pode-se perceber que o trecho narrado por Jô Soares está inserido nessa linhagem; afinal, o riso era o que se tinha à disposição como forma de resistência imediata à repressão ${ }^{173}$. Aliás, vale destacar que, mesmo enfrentando a ameaça de prisão e diversos processos na Justiça Militar (assim como os demais intelectuais que foram presos na mesma ocasião), Mario Schenberg buscava privilegiar o aspecto positivo do momento.

\footnotetext{
${ }^{170}$ Sobre isso, Jô Soares escreve: "Penso em quanto a física brasileira, historicamente necessitada de apoio, pode ter sido prejudicada em seu desenvolvimento pelo fato de Mario Schenberg não poder trabalhar. O prejuízo que a ditadura causou ao país com as perseguições aos cientistas de esquerda é incalculável." (SOARES, 2017, p. 422).

171 MOTTA, Rodrigo P. Sá. As universidades e o regime militar: cultura política brasileira e modernização autoritária. 1 1a edição. Rio de Janeiro: Zahar, 2014.

172 "Jaguar, ou Sérgio Jaguaribe, chargista que publicava em jornais de oposição aos militares, como Última Hora, fez várias charges ridicularizando a ignorância dos agentes da Ordem. Outros chargistas e caricaturistas se destacaram nas críticas ao regime militar, como Ziraldo, Henfil, Claudius, Fortuna, entre outros. O cronista Sérgio Porto fez o mesmo em seus textos ferinos, reunidos na série de livros Febeapá (Festival de Besteira que Assola o País), publicados entre 1966 e 1968." (MOTTA, 2014, p. 364).

${ }^{173}$ Cf. SOARES, Jô. O Livro de Jô: uma biografia desautorizada. 1 $1^{\text {a }}$ edição. São Paulo: Companhia das Letras, 2017.
} 
Ana Clara Guerrini Schenberg (2018) assinala essa característica do comportamento do crítico, dando como exemplo uma carta que Schenberg escrevera para ela quando estava em casa de amigos ${ }^{174}$. Nela, o crítico diz:

Estou muito bem disposto, descansado, preparando minha defesa. Gosto de lutar. Dá ânimo e sentido à vida.

Tenho devorado livros. Não paro em lugar nenhum. Onde vou encontro alguns que não li e aproveito. Continuando assim ficarei afiadíssimo. Tenho também criado novas amizades e tido experiências interessantes. É uma fase muito estimulante da vida em que me libertei das obrigações rotineiras e tenho sossego para pensar no que quero. ${ }^{175}$

Durante o tempo em que precisou ficar na clandestinidade, o crítico também contou com o apoio de colegas da Faculdade de Filosofia, Ciências e Letras da USP, que fizeram reuniões fora do campus da Universidade de São Paulo e tomaram o cuidado de obter a assinatura de Schenberg em ata oficial. Com isso, haveria prova legal de que o professor catedrático participava de atividades universitárias. Isso foi muito importante, pois resguardava o cientista perante a possibilidade de perda do cargo por abandono de função ${ }^{176}$ (MOTTA, 2014).

Ainda em 1964, repercussões desses inquéritos levariam à expedição de um segundo mandado de prisão preventiva em 13 de outubro, que seria finalizado apenas seis dias depois, em 19 de outubro. Nessa ocasião, o crítico não compareceu, permanecendo foragido. Com relação a esse fato, há uma lacuna na documentação disponível no prontuário de Mario Schenberg no DOPS, que não inclui dados sobre o habeas corpus concedido ao crítico em 24 de março de 1965. Felizmente, a imprensa da época não deixou de veicular os desdobramentos desse caso e por meio dela foi possível levantar informações sobre seu desfecho.

Tendo em vista o status de Mario Schenberg como cientista reconhecido mundialmente, os jornais deram destaque ao caso, que chegou a figurar na primeira

\footnotetext{
174 [Informação verbal] SCHENBERG, Ana Clara Guerrini. Entrevista concedida a Ana Paula Cattai Pismel. São Paulo, 11 mai. 2018. 2 arquivos .mp3 (40’41'). [A entrevista encontra-se depositada no Centro Mario Schenberg de Documentação da Pesquisa em Arte - ECA/USP]. Ana Clara é filha de Julieta Bárbara e Mario Schenberg.

${ }^{175}$ Carta enviada por Mario Schenberg a Ana Clara Guerrini Schenberg, ca. 1964. Fonte: Arquivo pessoal de Ana Clara Schenberg.

176 “A propósito, o mecanismo administrativo do abandono de cargo serviu como estratégia para conseguir o expurgo por meios indiretos, quando não havia condições políticas e legais para demitir os 'indesejáveis' de maneira direta. O estratagema era manter forte pressão sobre os alvos, conservando-os na cadeia ou obrigando-os à clandestinidade, de maneira a impedir seu comparecimento ao trabalho" (MOTTA, 2014, p. 57).
} 
página, por exemplo, do Última Hora, edição de São Paulo ${ }^{177}$. Já na edição do Rio de Janeiro foi noticiado que:

Em decisão de ontem, o Superior Tribunal Militar concedeu, por unanimidade, o habeas-corpus ao cientista Mario Schenberg, físico de fama mundial, acusado de comunista. O advogado de defesa, Raul Lins e Silva, sustentou a tese de falta de justa causa, aceita unanimemente pelo STM e justificada de maneira incisiva e eletrizante pelo Ministro Peri Bevilacqua. O Ministro-General afirmou a "inviolabilidade de consciência" e manifestou sua repulsa "contra os que desejam fazer da justiça militar um instrumento de perseguição política" $"$.

Pode-se notar que, mesmo dentro dos setores que apoiaram a instauração do Regime Militar, nem todos estavam de acordo com aqueles que "desejam fazer da justiça militar um instrumento de perseguição política", conforme afirmou o Ministro-General Pery Bevilacqua. Ao dar seu voto, este teria defendido ainda as liberdades individuais, considerando a não punibilidade prevista em lei para posição ideológica ${ }^{179}$.

Em 1964 já era possível aquilatar o impacto internacional da perseguição sofrida por Mario Schenberg, que talvez tenha sido o professor que mais atraiu solidariedade do exterior. Em seu favor, o governo recebeu manifestos dos Estados Unidos, da Europa e do Japão. Ademais, é possível que a pressão internacional em favor do crítico tenha feito com que ele não fosse demitido da FFCL da Universidade de São Paulo já em 1964 (MOTTA, 2014). Um exemplo é o que publicou a imprensa de então:

O mundo inteiro quer a colaboração de Schenberg, enquanto o Brasil o prende. A Escola Politécnica de Paris chega a torcer por um "sim" deste cientista. Enquanto isso, todo o seu trabalho fica abandonado na Faculdade de Filosofia de São Paulo. O laboratório de Ressonância Nuclear, por exemplo, estava sendo montado quando o juiz da Auditoria Militar decretou sua prisão...

[...]

Quando o governo do General Dutra iniciou o "expurgo" [...], o DOPS perseguiu o cientista Mario Schenberg. Einstein soube, e enviou uma carta ao governo brasileiro, afirmando, de próprio punho, que "meu discípulo possui qualidades para ser o continuador de minha obra". [...]

Mario Schenberg, amigo e colaborador [de] prêmios Nobel, conhecido em qualquer país, recebeu manifestações do mundo inteiro: 58 cientistas alemães advertiram, em manifesto enviado ao governo

177 Última Hora, $2^{\mathrm{a}}$ edição, São Paulo, 25 mar. 1965 (capa). Vide a sessão de Anexos desta tese.

${ }_{178}$ IPM's condenados. Última Hora, Rio de Janeiro, 25 mar. 1965.

${ }^{179}$ STM dá habeas de Schenberg e Pery faz novas denúncias. Correio da Manhã, 25 mar. 1965. 
brasileiro, que a perseguição a esse cientista ameaçava o intercâmbio cultural Brasil-Alemanha (não é a comunista, não); entidades de vários países e protestos isolados invadiram o Itamaraty e o Planalto. Mas a Perseguição continua ${ }^{180}$.

Contudo, em setembro de 1965 foram instaurados novos inquéritos e, mais uma vez, foi decretada a prisão preventiva de Mario Schenberg, que iria participar de um importante evento científico no Japão no ano seguinte ${ }^{181}$. Por estar respondendo a processos, não poderia sair do país ${ }^{182}$. O crítico permaneceu foragido durante três semanas até que, em atitude estratégica, entregou-se à polícia, ainda em 1965. Estratégica, pois Schenberg foi o único cientista latino-americano convidado para o Congresso Internacional de Partículas Elementares que seria realizado no Japão. Ao se apresentar à polícia, apostou na força da repercussão internacional que teve sua prisão no ano anterior, o que de fato aconteceu ${ }^{183}$. O depoimento da artista Lourdes Cedran ${ }^{184}$ demonstra a consciência do crítico a respeito do desfecho de sua atitude:

Naqueles dias, Mário deveria viajar para o Japão para um encontro científico da maior importância. Ele era o único latino-americano convidado. Em um lance estratégico ele decidiu entregar-se à polícia, e com isso chamou a atenção da comunidade científica internacional para as arbitrariedades do regime brasileiro. Em seguida telefonou

\footnotetext{
${ }^{180}$ Herdeiro de Einstein ou de simples bandido? Última Hora, 24 nov. 1964, p. 11.

${ }^{181}$ O próprio crítico relata sobre a ocasião: “Em 1965, eu fui ao Japão para esse congresso. Foi uma coisa muito dramática. Eu tive que pedir licença para viajar, mas como eu estava com um processo, decretaram a minha prisão preventiva. Eu tinha até me escondido; depois eu me entreguei, mas consegui habeas corpus e pude ir ao Japão. [...] Foi nessa conferência de Kioto que eu comecei a escrever um trabalho que devia ter sido feito para sair no livro em homenagem ao professor Gamow. Infelizmente, eu estava com muitos problemas, muitas coisas aí, toda a situação política estava muito precária, e eu não consegui fazer o trabalho em tempo. Depois eu concluí e, finalmente, publiquei no primeiro número da Revista Brasileira de Física". SCHENBERG, Mário. Mário Schenberg (depoimento, 1978). Rio de Janeiro, CPDOC, 2010, p. 34-35.

182 “Começava uma batalha judicial pela liberdade, pela defesa da Cátedra de Mário Schenberg e até mesmo pelos vencimentos cortados durante o período em que esteve ameaçado de prisão. Chegou a ter, durante esse período, a sua biblioteca destruída e os seus quadros [...] dilacerados pelos policiais que conduziam as 'investigações' em busca de provas que pudessem incriminá-lo". CLEMENTE, José Eduardo Ferraz. Ciência e política durante a ditadura militar: o caso da comunidade brasileira de físicos (1964-1979). Salvador: Universidade Federal da Bahia, Instituto de Física, 2005. (dissertação de Mestrado), p. 102.

183 “(...) [Schenberg] resolveu então se entregar no exército do Ibirapuera porque sabia que no momento em que se entregasse, chegariam centenas de telegramas do mundo inteiro pedindo sua presença no congresso. Assim, fez com que o exército fosse obrigado a dar o passaporte para ele ir ao congresso." (GOLDFARB, José Luis. José Luis Goldfarb. In AJZENBERG, Elza. In Schenberg: Arte e Ciência. São Paulo: ECA/USP, 1997, p.45). A solidariedade da comunidade científica em nível nacional e internacional já havia se mostrado em sua prisão anterior, logo após o golpe. (CLEMENTE, José Eduardo Ferraz. Ciência e política durante a ditadura militar: o caso da comunidade brasileira de físicos (19641979). Salvador: Universidade Federal da Bahia, Instituto de Física, 2005. (dissertação de Mestrado), p. 98).

${ }^{184}$ CEDRAN, Lourdes. Lourdes Cedran. In SCHENBERG, Mário. Mário Schenberg: Entre-Vistas. São Paulo: Perspectiva, 1984, p. 68-70.
} 
para a Escola e me disse: "já estou preso, venha visitar-me no batalhão da Rua Jorge Miranda". Embora estranhando o fato, fui ao seu encontro. [...] Contou-me que seu advogado, Dr. Aldo Lins e Silva, já estava tratando de tudo e que provavelmente seria libertado no mesmo dia. Disse então que ficasse calma e que esperasse na Bienal. [...] Às nove da noite ele chegou na Bienal para alegria e surpresa de todos e no dia seguinte embarcou para o Japão, pois the foi concedido um habeas-corpus.

De fato, após se entregar, Schenberg obteve a autorização para a viagem, graças, em grande parte, à repercussão do fato às vésperas do relevante evento científico. A reconstituição das datas nas quais Schenberg esteve ou não sob ameaça de prisão no decorrer de 1965 é importante, pois é assim que será possível esclarecer a seguinte pergunta: diante do contexto tão conturbado vivido pelo crítico entre 1964 e 1965, como foi possível que ele participasse dos trabalhos do Júri de Seleção da Bienal?

Se o crítico estivesse sob mandado de prisão, não poderia ter se dirigido ao Parque do Ibirapuera para as reuniões efetuadas no início do mês de maio de 1965. Um outro dado que motivou o aprofundamento da pesquisa nesse ponto vem da seguinte suposição: uma vez que todas as decisões a respeito do Júri de Seleção e dos demais trâmites da organização das bienais eram publicados amplamente nos jornais, seria altamente provável que houvesse agentes policiais esperando por Mario Schenberg no Pavilhão da Bienal para prendê-lo antes mesmo do início dos trabalhos.

Além disso, teria a Bienal se arriscado a manter um membro do Júri de Seleção foragido? Certamente não, mesmo que isso tivesse por objetivo resguardar o próprio crítico e, ao mesmo tempo, a Fundação Bienal. Diante dessa pergunta, recorreu-se novamente à análise da documentação que integra o prontuário de Schenberg no DOPS, bem como à imprensa da época, com a finalidade de encontrar respostas.

Como já foi dito, em setembro de 1965 foi expedido um novo mandado de prisão preventiva contra Mario Scheberg. Antes disso, o crítico tinha ficado escondido em casa de amigos até o dia 24 de março de 1965, quando obteve um habeas corpus em seu favor. Com isso, entre março e setembro Schenberg teve garantido seu direito de ir e vir.

As atividades do Júri de seleção da Bienal, por sua vez, tiveram o seguinte calendário: em 27 de abril foram conhecidos os nomes dos representantes dos artistas, sendo que Schenberg só passou a integrar o júri em 6 de maio, em substituição a dois outros jurados eleitos pelos artistas, que não puderam estar presentes. No início de maio se deram as reuniões do Júri de Seleção, que deliberaram sobre a composição da 
representação brasileira no certame. Em 19 de maio, Francisco Mattarazzo Sobrinho enviou para a secretaria da Fundação Bienal a relação dos artistas escolhidos pelo júri ${ }^{185}$. Com base nessas datas, conclui-se que, ao participar dos trabalhos do Júri de Seleção da Bienal de 1965, Mario Schenberg não enfrentava restrições, nem estava sob mandado de prisão. Ocorrendo em maio, as reuniões estavam fora do período em que o crítico precisou ficar escondido (que terminou em 24 de março) e a expedição do novo mandado de prisão (apenas em setembro de 1965).

185 Arquivo Histórico Wanda Svevo, Fundação Bienal. 
Figura 21 - Mário Schenberg, professor e político, ao lado de sua esposa, deixando a prisão. Publicada em 25 set. 1965.

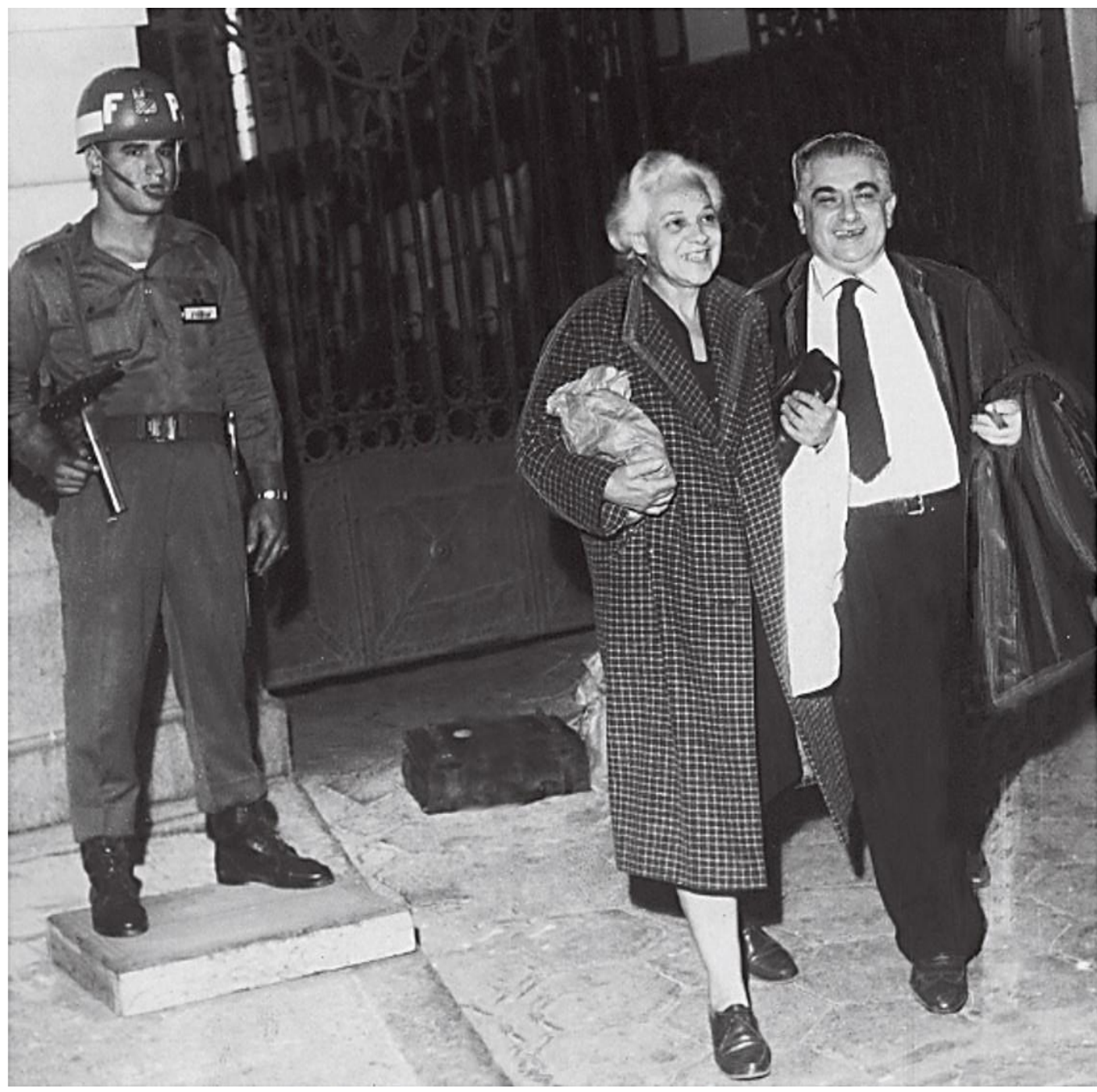

Fonte: Acervo Última Hora/Folhapress. 
Nesse período tumultuado, também foi importante o contato entre Schenberg e os artistas com os quais conviveu. Quando não estava sendo procurado, eram comuns as reuniões em sua residência na Rua São Vicente de Paula, nas quais muito se conversava sobre arte e política. Além disso, tais oportunidades permitiram ao crítico conhecer mais profundamente os artistas sobre os quais escreveu. Muitos deles apontaram que as conversas com Schenberg foram extremamente produtivas e marcantes em sua trajetória artística.

Cabe dizer que até o ano de 1969, quando, por força do Ato Institucional $n^{\circ} 5$, foi aposentado compulsoriamente de seu cargo na Universidade de São Paulo, Mario Schenberg conciliava a atuação como cientista, a militância política e a crítica de arte. Somente após esse afastamento passou a ter na última sua principal atividade ${ }^{186}$.

Conforme já observado, ao integrar o Júri de Seleção da VIII Bienal, Mario Schenberg estava enfrentando diversos processos judiciais. Foi em meio a essa tensão que o crítico participou, no decorrer de maio de 1965, de algumas das reuniões para selecionar as obras que participariam da edição daquele ano. Segundo o regulamento da VIII Bienal, o Júri de Seleção era composto por cinco membros, todos escolhidos pelos artistas. Tinham direito a voto apenas aqueles que já haviam participado de pelo menos uma bienal anterior. Cada um deles indicava dois nomes no ato de sua inscrição que, depositados numa urna, aguardavam o dia marcado para apuração ${ }^{187}$.

Em 27 de abril de 1965 foram conhecidos os nomes dos representantes dos artistas: José Geraldo Vieira (71 votos), Walter Zanini (64), Geraldo Ferraz (38), Fernando Lemos (33) e Mário Pedrosa (31). Em seguida, Sérgio Milliet (25) e Mario Schenberg (22) ficaram como suplentes ${ }^{188}$. Em 30 de abril, Walter Zanini escreve a Diná Lopes Coelho, secretária da Fundação Bienal, informando que viajaria para o Japão a fim de participar do Júri de Seleção da Bienal de Tóquio e não conseguiria retornar ao país a tempo de integrar o júri brasileiro ${ }^{189}$.

Conforme o regulamento, o crítico Sérgio Milliet foi chamado para substituí-lo, mas pôde comparecer apenas à primeira reunião do Júri, no Museu de Arte Moderna do

\footnotetext{
${ }^{186}$ OLIVEIRA, Alecsandra Matias de. Schenberg: crítica e criação. São Paulo: EDUSP, 2010.

${ }^{187}$ FUNDAÇÃO BIENAL. VIII Bienal. (catálogo de exposição) São Paulo: Fundação Bienal, 1965, p. 20. Até a III Bienal, em 1955, a indicação dos dois nomes para o Júri era feita em espaço destinado a isso na própria ficha de inscrição. A partir da IV Bienal, a votação passou a ser feita em cédulas não identificadas, conforme descrito acima (Arquivo Histórico Wanda Svevo, Fundação Bienal).

188 ZANINI, Ivo. Indicado o Júri da VIII Bienal. Folha de S. Paulo, 27 abr. 1965.

${ }^{189}$ Carta de Walter Zanini a Diná Coelho Lopes, de 30 de abril de 1961 (Arquivo Histórico Wanda Svevo, Fundação Bienal).
} 
Rio de Janeiro, em 6 de maio. Nas reuniões posteriores, Mario Schenberg esteve presente em seu lugar ${ }^{190}$. Na ata final do Júri Nacional de Seleção, quando em nota divulgada à imprensa ao final dos trabalhos, é o nome de Mario Schenberg que consta no lugar do de Walter Zanini como membro eleito pelos artistas ${ }^{191}$.

Uma vez integrando o Júri, Mario Schenberg não hesitou em defender os artistas com os quais mantinha contato, notadamente aqueles que estavam alinhados com tendências como as novas figurações, a saber: José Roberto Aguilar, Cláudio Tozzi e Rubens Guerchmann, entre outros, e a arte primitiva, como Waldomiro de Deus. Após o fim dos trabalhos de seleção das obras para a VIII Bienal, Aracy Amaral traça um perfil das interações dos membros do Júri, no qual aponta Mário Pedrosa e Mario Schenberg como os maiores definidores das escolhas feitas pelo grupo no interior das discussões "tão comuns nesse tipo de Seleção"192.

O crítico não pôde comparecer à inauguração da VIII Bienal de São Paulo em 4 de setembro, pois já havia sido expedido contra ele o novo mandado de prisão. Além da comunidade científica internacional, os artistas também manifestaram seu apoio. $\mathrm{Na}$ inauguração da VIII Bienal, quando da cerimônia de premiação, a artista Maria Bonomi (premiada naquela edição) foi ao encontro do presidente da república, o militar Humberto Castelo Branco, e entregou a ele uma carta que ficou conhecida como Manifesto dos 4. Esse documento, assinado por vários artistas, continha o pedido para que o presidente intercedesse em favor de Mario Schenberg, Florestan Fernandes, João Cruz Costa e Fernando Henrique Cardoso, docentes da Faculdade de Filosofia, Ciências e Letras da Universidade de São Paulo ${ }^{193}$.

$\mathrm{Na}$ ocasião, a artista relatou que, como teria de ir até onde estava o Presidente para receber dele seu prêmio, aproveitou a ocasião para levar o abaixo-assinado diretamente. Ele estava sempre cercado de militares com armas em punho e dificilmente alguém que estivesse fora do protocolo teria acesso a Castelo Branco sem ser tomado

\footnotetext{
${ }^{190}$ Sérgio Milliet teve de ser substituído às vésperas de viajar ao Rio de Janeiro para o prosseguimento dos trabalhos do Júri devido a um mal-estar (Schenberg em Vez de Milliet. Correio da Manhã, Estado da Guanabara, 7 mai. 1965).

${ }^{191}$ Em 19 de maio, Francisco Matarazzo Sobrinho envia a Vasco Mariz, chefe da divisão de difusão cultural da Fundação Bienal, a lista de artistas que foram aceitos na oitava edição do evento, na qual constava a composição final do Júri de Seleção (Arquivo Histórico Wanda Svevo, Fundação Bienal).

192 "O trabalho do Júri, além de difícil, duro e intenso, foi marcado por discussões tão comuns nesse tipo de seleção. Mario Pedrosa e Mario Schenberg, ao que tudo indica, definiam as escolhas, parece ter havido pouca identidade de pontos de vista entre Geraldo Ferraz e Fernando Lemos. José Geraldo Vieira, como sempre, atuou como poder moderador" (AMARAL, Aracy. Terminada a Seleção da Bienal. A Gazeta, São Paulo (capital), 18 mai. 1965).

193 O texto integral do Manifesto dos 4 foi incluído entre os Anexos deste estudo.
} 
como ameaça ${ }^{194}$. Segundo relatou Maria Bonomi $(2018)^{195}$, foi uma cerimônia bastante tensa:

Você vê aí como era precário o sistema para nós, porque quem ia entregar o prêmio era o presidente, que estava sentado numa cadeira lá no alto e, embaixo, estavam os guardas, com as armas apontadas para a plateia. Quer dizer, é como se a gente fosse ser fuzilado. Eu lembro bem dessa cena. Então nós estávamos aqui [na plateia], e os caras, com as armas abaixadas, mas era só fazer isso aqui [levantálas], cercando as autoridades. Aí, quando chamaram "Maria Bonomi - Prêmio de Gravura", eu fui lá e, com uma mão, entreguei o documento e, com a direita, eu recebi o prêmio.

Note-se que mesmo a artista, que fora chamada a se aproximar do Presidente, se arriscou ao entregar a ele o documento. Algum dos militares que fazia a segurança poderia tê-la interpelado pelo papel que ela levava nas mãos ao se aproximar do palanque onde estavam as autoridades. Felizmente, isso não aconteceu e quando a artista ficou diante de Castelo Branco disse "Presidente, quero lhe entregar", ao que ele respondeu "Está comigo", ao apertar sua mão (BONOMI, 2018) ${ }^{196}$.

\footnotetext{
${ }^{194}$ Maria Bonomi relatou sobre o ocorrido: “'Estamos com o documento aqui, Maria'. E eu disse: 'Pode deixar, que eu entrego'. Ninguém queria entregar, todo mundo morria de medo. Ninguém queria se aproximar e a situação física era complicada. [...] E era a grande chance [de outros não terem sucesso], mas eu ia poder entregar. Porque o Castelo Branco andava pelas salas com um monte de brucutu, um monte de gente acompanhando. Ele visitou a bienal inteira, aí chegou lá pra fazer a entrega. Eu tenho isso visualmente perfeito na minha cabeça. [Informação verbal] BONOMI, Maria. Entrevista concedida a Ana Paula Cattai Pismel. São Paulo, 16 mai. 2018. 4 arquivos .mp3 (1h46’15’). [A entrevista encontra-se depositada no Centro Mario Schenberg de Documentação da Pesquisa em Arte - ECA/USP].

195 [Informação verbal] BONOMI, Maria. Entrevista concedida a Ana Paula Cattai Pismel. São Paulo, 16 mai. 2018. 4 arquivos .mp3 (1h46'15'). [A entrevista encontra-se depositada no Centro Mario Schenberg de Documentação da Pesquisa em Arte - ECA/USP].

${ }^{196}$ É necessário assinalar que, diferentemente do que se relatava, o artista Sérgio Camargo não participou da entrega do Manifesto dos 4, conforme Leonor Amarante (1989) havia registrado. [Informação verbal] BOMONI, Maria. Entrevista concedida a Ana Paula Cattai Pismel. São Paulo, 16 mai. 2018. 4 arquivos .mp3 (1h46'15'). [A entrevista encontra-se depositada no Centro Mario Schenberg de Documentação da Pesquisa em Arte - ECA/USP].
} 
Figura 22 - Gravuras de Maria Bonomi expostas na VIII Bienal de São Paulo. A artista recebeu o prêmio de melhor gravadora nacional na edição.

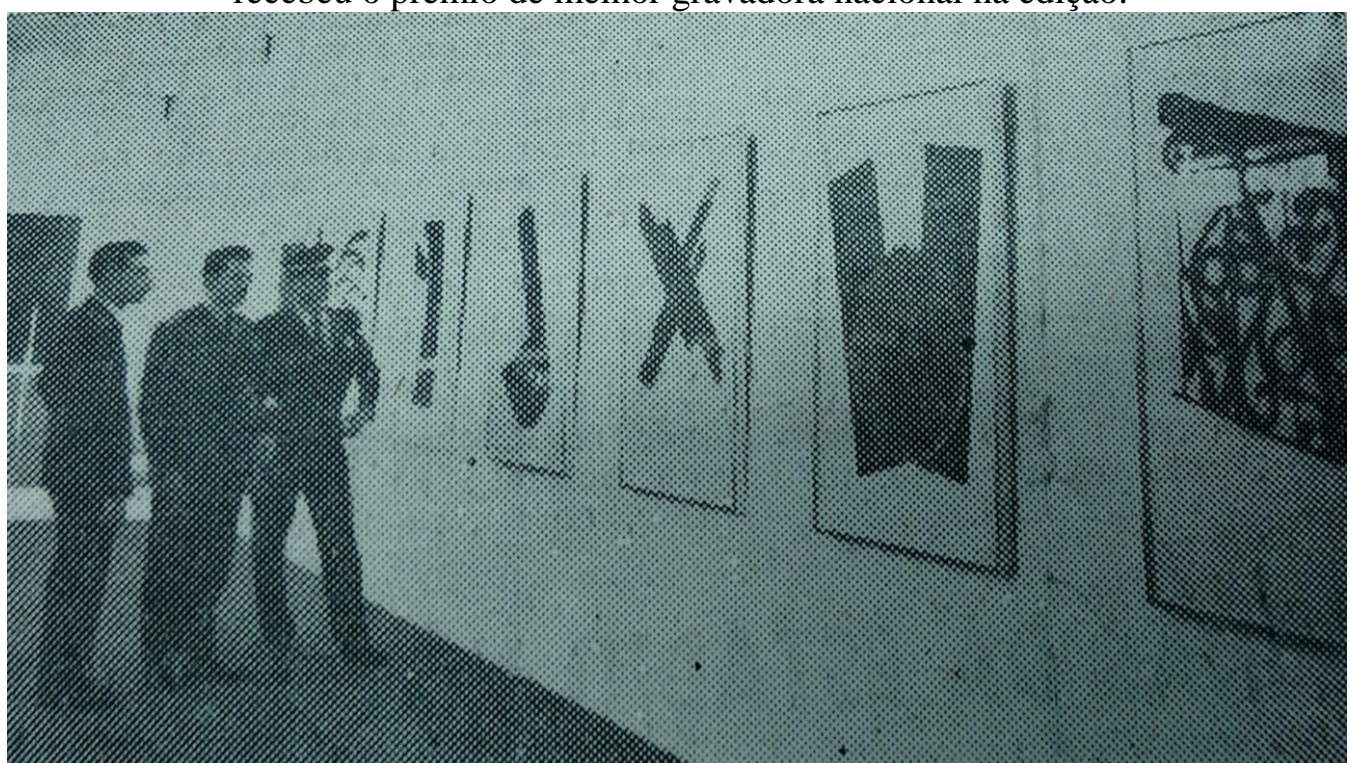

Fonte: São Paulo inaugura hoje a VIII Bienal. A Gazeta - São Paulo (Capital), 4 ago. 1965.

Figura 23 - Maria Bonomi, 1965, xilogravura sobre papel de arroz, 130 x 108.

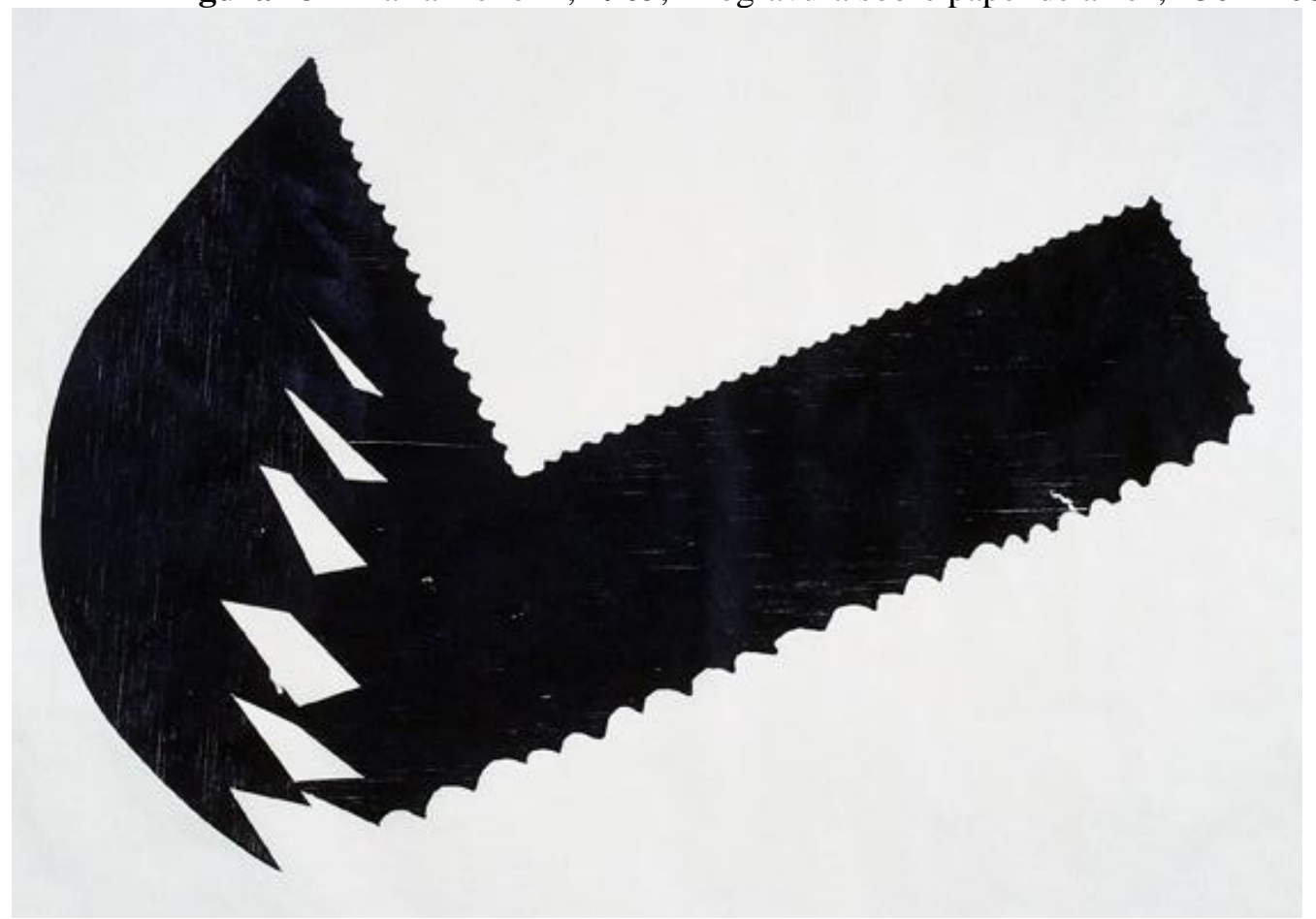

Fonte: Amarante, 1989. Note-se que, segundo Maria Bonomi (2018), a gravura deve ser exposta na horizontal, do modo como foi colocada aqui, e não na vertical, conforme foi exposta na VIII Bienal. 
Figura 25 - Maria Bonomi, 1965.

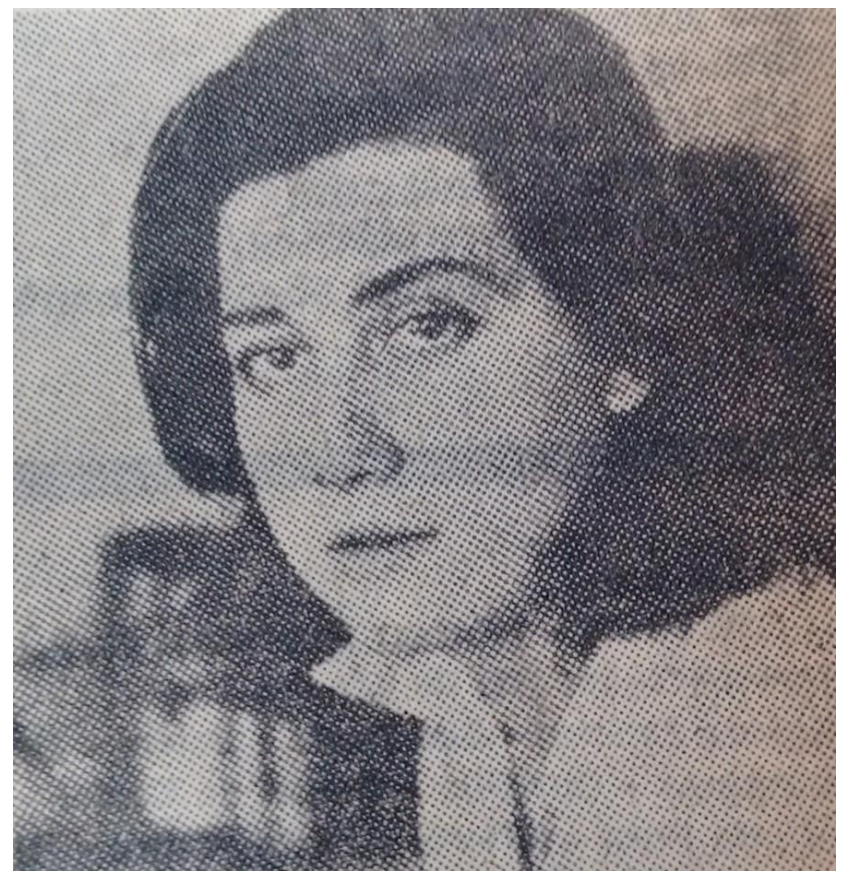

Fonte: Os primeiros prêmios da VIII Bienal. O Globo (Estado da Guanabara), 1 ago. 1965.

Figura 24 - Abertura da $8^{a}$ Bienal com as presenças do presidente Castelo Branco, Francisco Matarazzo Sobrinho e Paulo Mendes de Almeida. Autor não identificado.

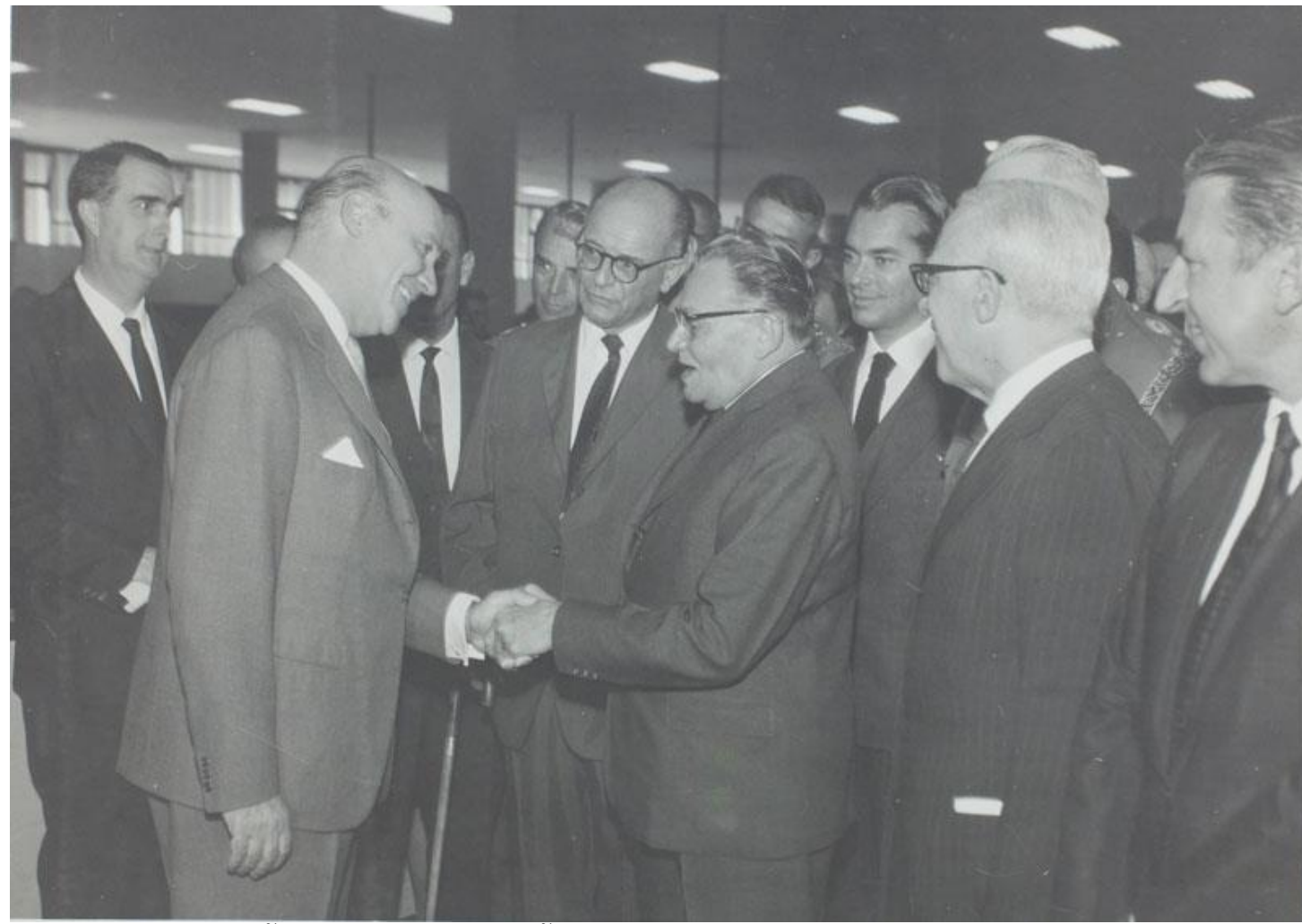

Fonte: FUNDAÇÃo BIENAL DE SÃO PAULO. $\mathbf{8}^{\text {a }}$ Bienal de São Paulo. Disponível em: $<$ http://www.bienal.org.br/exposicoes/8bienal/fotos/3880>. Acesso em: 12 jun. 2018. 
Sobre Mario Schenberg, aliás, Maria Bonomi afirmou que o crítico não era apenas um avaliador, que chegava ao atelier e se contentava em olhar de tudo. Em seu entender, Schenberg fazia análises importantes que tinham grande profundidade e tal procedimento teria sido o diferencial que ele entregou à bienal ${ }^{197}$. Na década de 1970 , por exemplo, quando a artista estava trabalhando com o entalhe (pois considerava que a gravação era festiva, ao passo que o entalhe tinha mais rigidez), esteve próxima de Mario Schenberg. Maria Bonomi destaca sobre esse momento: "Ele me disse muita impoante sobre isso, sobre o meu trabalho, que eu achava importante"198.

Apesar de não estar entre os artistas mais próximos ao crítico, Maria Bonomi relata que, nas poucas vezes em que Schenberg falou sobre o trabalho dela, o fez com uma poderosa percepção. Segundo a artista, ficava claro que, em sua análise, o crítico adentrava aspectos do processo criativo com grande profundidade ${ }^{199}$. É desse período a série Balada do Terror, que homenageia Dulce Maia, presa e torturada pelo Regime Militar $^{200}$. O trabalho foi premiado na mostra Panorama 1971, no Museu de Arte Moderna de São Paulo ${ }^{201}$.

Assim como Schenberg acompanhou seu trabalho por certo período, Maria Bonomi acredita que o crítico tenha feito o mesmo com os diversos artistas dos quais se aproximou no decorrer de sua atuação nas bienais. Nessa interação, o crítico teria atuado com muita liberdade, não ficando restrito a receitas prontas, mas trazendo em suas apreciações as peculiaridades que o tornavam inovador ${ }^{202}$.

\footnotetext{
197 [Informação verbal] BONOMI, Maria. Entrevista concedida a Ana Paula Cattai Pismel. São Paulo, 16 mai. 2018. 4 arquivos .mp3 (1h46'15'). [A entrevista encontra-se depositada no Centro Mario Schenberg de Documentação da Pesquisa em Arte - ECA/USP].

198 [Informação verbal] BONOMI, Maria. Entrevista concedida a Ana Paula Cattai Pismel. São Paulo, 16 mai. 2018. 4 arquivos .mp3 (1h46'15')). [A entrevista encontra-se depositada no Centro Mario Schenberg de Documentação da Pesquisa em Arte - ECA/USP].

199 [Informação verbal] BONOMI, Maria. Entrevista concedida a Ana Paula Cattai Pismel. São Paulo, 16 mai. 2018. 4 arquivos .mp3 (1h46'15'). [A entrevista encontra-se depositada no Centro Mario Schenberg de Documentação da Pesquisa em Arte - ECA/USP].

${ }^{200}$ Exposição revisita obras de Maria Bonomi. Folha de São Paulo, Ilustrada. Disponível em: $\langle$ https://www1.folha.uol.com.br/fsp/ilustrada/45945-exposicao-revisita-obra-de-maria-bonomi.shtml〉. Acesso em: 10 jun. 2018.

${ }^{201}$ Assinale-se que Maria Bonomi também foi presa na década de 1970. Esses e outros episódios ligados à Ditadura estão registrados em BONOMI, Maria. Depoimento Maria Bonomi. In Revista da Biblioteca Mário de Andrade. O Medo, São Paulo, nº 70, 2016, p. 148-163.

202 [Informação verbal] BOMONI, Maria. Entrevista concedida a Ana Paula Cattai Pismel. São Paulo, 16 mai. 2018. 4 arquivos .mp3 (1h46'15'). [A entrevista encontra-se depositada no Centro Mario Schenberg de Documentação da Pesquisa em Arte - ECA/USP].
} 
Figura 26 - Maria Bonomi, Balada do Terror, 1970. Xilogravura em cores, 204,8 x 83,3 cm. Museu de Arte Moderna de São Paulo.

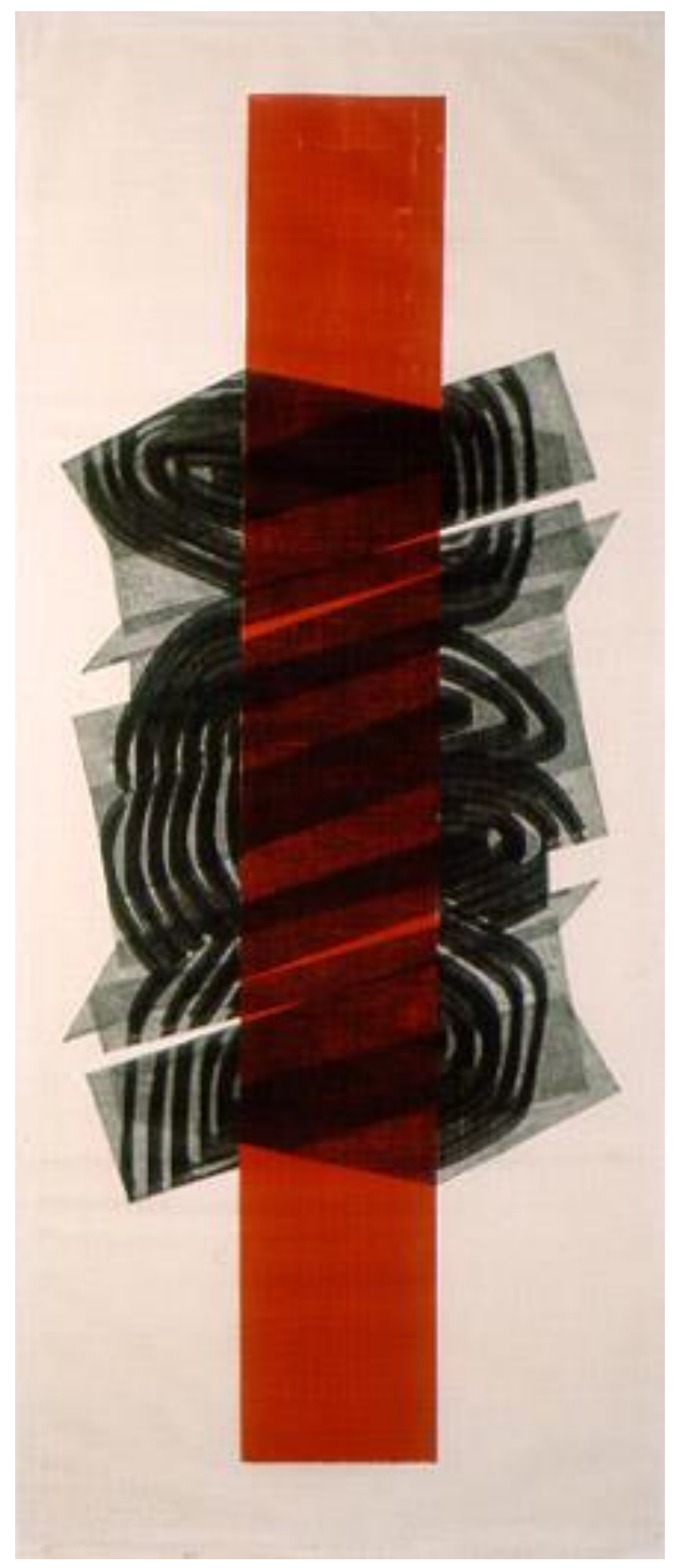

Fonte: Acervo MAM-SP. Disponível em: 〈http://mam.org.br/acervo/322-bonomi-maria/〉. Acesso em: 12 jun. 2018. 
É importante destacar alguns achados que levaram a uma nova compreensão sobre o que se deu, de fato, na abertura da Bienal de 1965, em 4 de setembro. Até o momento, a literatura indicava que Mario Schenberg estivesse preso ${ }^{203}$. Contudo, um aprofundamento da pesquisa nos dados do prontuário do crítico no DOPS, bem como na imprensa de então, permitiu que se compreendesse melhor a cadeia de acontecimentos que cerca o evento, bem como a segunda prisão de Schenberg na década de 1960. Foi somente em 22 de setembro que o crítico decidiu se entregar, contando, mais uma vez, com a repercussão internacional decorrente de sua prisão. Em 24 de setembro, apenas dois dias depois, foi expedido um habeas corpus em favor de Schenberg, que no dia seguinte embarcou para o Japão ${ }^{204}$. Com relação a esse episódio, o único documento que consta no prontuário de Schenberg no DPOS ${ }^{205}$ é uma via da autorização que o crítico obteve para viajar a Kioto, cuja reprodução foi incluída nos anexos deste trabalho.

Resta a dúvida sobre quando, exatamente, foi decretada a prisão preventiva de Mario Schenberg, uma vez que não se encontrou nos documentos analisados nenhuma confirmação a respeito. Há elementos que permitem situar a expedição do mandado no mês de setembro (MOTTA, 2014). Como a inauguração da Bienal de 1965 se deu no dia 4 do mesmo mês, para que Schenberg não pudesse comparecer, o mandato teria que ter sido expedido antes dessa data.

O próprio crítico pode nos esclarecer, por meio das informações que deu à imprensa antes de embarcar para Kioto, ainda no aeroporto de Congonhas. Ao explicar o motivo pelo qual não teria tido tempo para preparar sua fala no Congresso Internacional de Partículas Elementares que seria realizado em Tóquio (Japão), Mario Schenberg afirmou que, "tendo em vista sua prisão preventiva, decretada pelas autoridades militares, o que o obrigou a permanecer escondido durante três semanas, não pôde elaborar um trabalho escrito, razão pela qual improvisará sua tese"206.

Levando em conta o intervalo de tempo no qual o crítico precisou ficar escondido, três semanas, pode-se chegar à data de expedição do mandado de prisão: $1^{\circ}$

\footnotetext{
${ }^{203} \mathrm{O}$ presente estudo continua pesquisa anterior, de mestrado, em relação à qual acrescenta dados atualizados. Cf. PISMEL, Ana Paula Cattai. Schenberg: em busca de um Novo Humanismo. São Paulo: Programa de Pós-Graduação Interunidades em Estética e História da Arte, Universidade de São Paulo, 2013 (dissertação de mestrado).

${ }^{204}$ Schenberg foi para o congresso no Japão. Última Hora, 27 set. 1965.

${ }^{205}$ Prontuário de Mario Schenberg, $n^{\circ}$ 89.583. Arquivo Geral do Departamento de Ordem Política e Social - DOPS. Arquivo do Estado de São Paulo.

${ }^{206}$ Schenberg foi para o congresso no Japão. Última Hora, 27 set. 1965.
} 
de setembro. Se o crítico se entregou em 22 de setembro, o intervalo entre os dias $1^{\circ} \mathrm{e}$ 21 corresponde com exatidão às três semanas por ele indicadas. Caso essa estimativa esteja correta - até o momento nada indica que não esteja - quando da inauguração da Bienal de 1965, Mario Schenberg não pôde comparecer pois já havia risco de que fosse preso em pleno evento ${ }^{207}$.

${ }^{207}$ Ainda em 1965, Mario Schenberg foi absolvido dos processos a que respondia desde 1964 e retomou suas atividades na Universidade de São Paulo. SCHENBERG, Mário. Mário Schenberg (depoimento, 1978). Rio de Janeiro, CPDOC, 2010. p. 39. Cf. OLIVEIRA, Alecsandra Matias. Schenberg: Crítica e Criação. São Paulo: EDUSP, 2011. 
Figura 27 - Schenberg foi para o congresso no Japão. Última Hora - 27/09/1965 - segunda-feira.
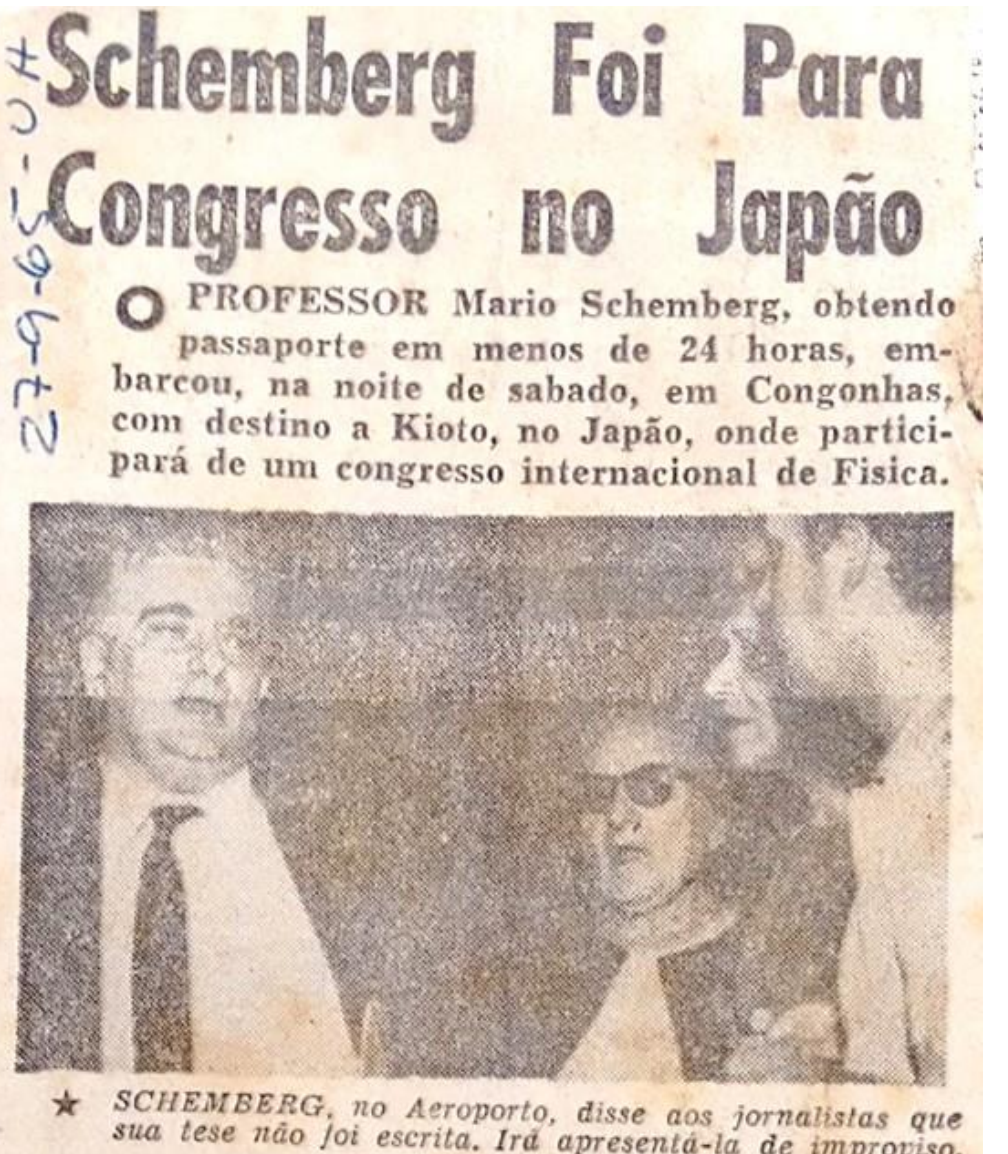

Nesse certame, o professor Mario Schemberg, unico latino-americano con vidado. apresentará uma tese sobre a natureza da carga eletrica. Falando à reportagem, afirmou que, tendo em vista a sua prisáo preventiva, decretada pelas autoridades militares. que o obrigou a permanecer escondido durante três semanas, náo pôde elaborar um trabalho escrito razâo pela qual improvisará sua tese.

O cientista permanecerá no Japão pouco maís de 10 dias. Participará dos trabalhos do congresso de fisicos - entre os quais há scte laureados com o premio Nobel - e visitará diversas universidades. Antes de embarcar, em aviáo da PanAmerican, declarou que, tão logo encerre seus trabalhos retornará ao Brasil.

O professor, detido desde

o dia 22 no Batalhăo de Guarclas da Forca Publica. fol posto em liberdade às 19.15 horas de sexta-feira por forca de habeas corpus concedido pelo STM. Ao sair da prisão, dirigiu-se aे $\mathrm{Fa}$ culdacie de Filosofia da Universidade de Săo Paulo, onde dirige o Departamento de Fisica, sendo recebido pelos alunos que o aplaudiram calorosamente. Aos estudantes, o professor Schemberg afirmou que dificilmente poderia atender ao convite feito pelos organizadores do congresso pois nẩo teria tempo para obter seu passaporte. Entretanto, conseguiu o documento em tempo habil. seguindo para o Japaso. A decisảo do STM, tomada por 5 votos contra 4 , estendeuse tambem ao professor João Cruz Costa. da Faculdade de Filosofia, acusado de "sub-

Fonte: Acervo Histórico IF/USP 
IX Bienal (1967): em busca dos novos valores

Momento final de um período de efervescência cultural no país, 1967 foi o ano de Terra em Transe, O Rei da vela, da exposição Nova Objetividade Brasileira, assim como de Tropicália, o ambiente de Hélio Oiticica e da explosão do tropicalismo na música, manifestações que marcaram os anos de $1960^{208}$. Cinema, teatro, música e artes plásticas manifestavam o anseio de dar uma contribuição original à esfera da cultura, seja em nível nacional, seja internacional. O crescendum dessa movimentação, iniciado na década de 1950 e perturbado com o golpe de 1964, seguiria até a decretação do AI5 , quatro anos depois.

Em 1967, a Pop Art ${ }^{209}$ norte-americana, que marcou presença na Bienal anterior, deu o tom da mostra. Não foi por acaso que a IX Bienal ficou conhecida como a Bienal do Pop. Apesar da repercussão da sala dos Estados Unidos ter sido significativa, outros países também trouxeram para a Bienal desdobramentos da Pop Art ${ }^{210}$.

${ }^{208}$ FAVERATO, Celso. A outra América. Folha de São Paulo, 09 de junho de 2001. Terra em Transe: filme de 1967, com direção de Glauber Rocha. O Rei da Vela: peça escrita por Oswald de Andrade em 1933, cuja montagem dirigida e encenada por José Celso Martins Corrêa junto ao Teatro Oficina em 1967 ficou conhecida internacionalmente. Nova Objetividade Brasileira: exposição realizada em abril de 1967 no MAM-RJ, com participação de diversos artistas e críticos, em torno da ideia de "nova objetividade", que começou a ser delineada por Hélio Oiticica na exposição-seminário Propostas 65, reconhecendo a contribuição de Mario Schenberg em sua formulação. Tropicália: ambiente elaborado por Hélio Oiticica, composto por um labirinto no qual estavam dois Penetráveis - PN2, 1966, Pureza é um Mito e PN3, 1966/1967, Imagético - junto a plantas, areia, poemas-objeto, capas de parangolé e um aparelho de televisão. (ITAÚ CULTURAL. Enciclopédia de Artes Visuais Itaú Cultural. Disponível em: <www.itaucultural.org.br> Acesso em 09 mai. 2013).

${ }^{209}$ Tendo surgido na Inglaterra nos anos 50, "mas polarizada e difundida pelos norte-americanos, a partir de 1962", a Arte Pop se consolidou "como uma "tela de fundo" poderosa à qual se remetiam como ressonâncias a maioria das manifestações figurativas e realistas dessa época" (Cf. PECCININI, Daisy. Figurações no Brasil: anos 60. In: Projeto Visitando o MAC na Web). Na Europa, essa vertente marcou presença com o Novo Realismo. Alguns elementos precursores do Pop, ainda no fim dos anos 50 foram, segundo Archer, "o interesse pelo corriqueiro, a disposição de abarcar o acaso (não apenas por uma herança do Dadaísmo, mas também o reconhecimento de que na vida as coisas simplesmente acontecem) e um novo senso visual" (ARCHER, Michael. Arte Contemporânea. São Paulo: Martins Fontes, 2008,, p. 5). A noção de assemblage, proveniente do Dadaísmo, teve desdobramentos na Arte Pop: tanto pelo fato de se retirar imagens e objetos de seu lugar no mundo comum, reorganizando-os na obra de arte, quanto pelo fato de que "essa conexão com o cotidiano, desde que não nos envergonhemos dela, deixa o caminho livre para uma vasta gama de materiais e técnicas até (...) o momento não associados ao fazer artístico" (ARCHER, Idem, Ibidem, p. 4). O "caminho livre" em potencial, aberto por essa nova sensibilidade, já bastante perceptível por volta de 1962, nas obras de artistas como Roy Lichtenstein, Andy Warhol, Claes Oldenburg, Tom Wesselman e James Rosenquist (ARCHER, Idem, Ibidem, p. 6), na medida em que as imagens e materiais provenientes da cultura visual de massas nos Estados Unidos eram a matéria-prima constante.

${ }^{210}$ AMARANTE, Leonor. As Bienais de São Paulo: 1951 a 1987. São Paulo: Projeto, 1989, p. 161. Um dos destaques da representação dos Estados Unidos foi a sala especial dedicada ao pintor Edward Hopper, falecido cinco messes antes da exposição e, então, recentemente reconhecido como precursor da Pop Art. (Idem, Ibidem, p. 167). 
Figura 28 - Sala especial Edward Hopper na 9a Bienal (1967).

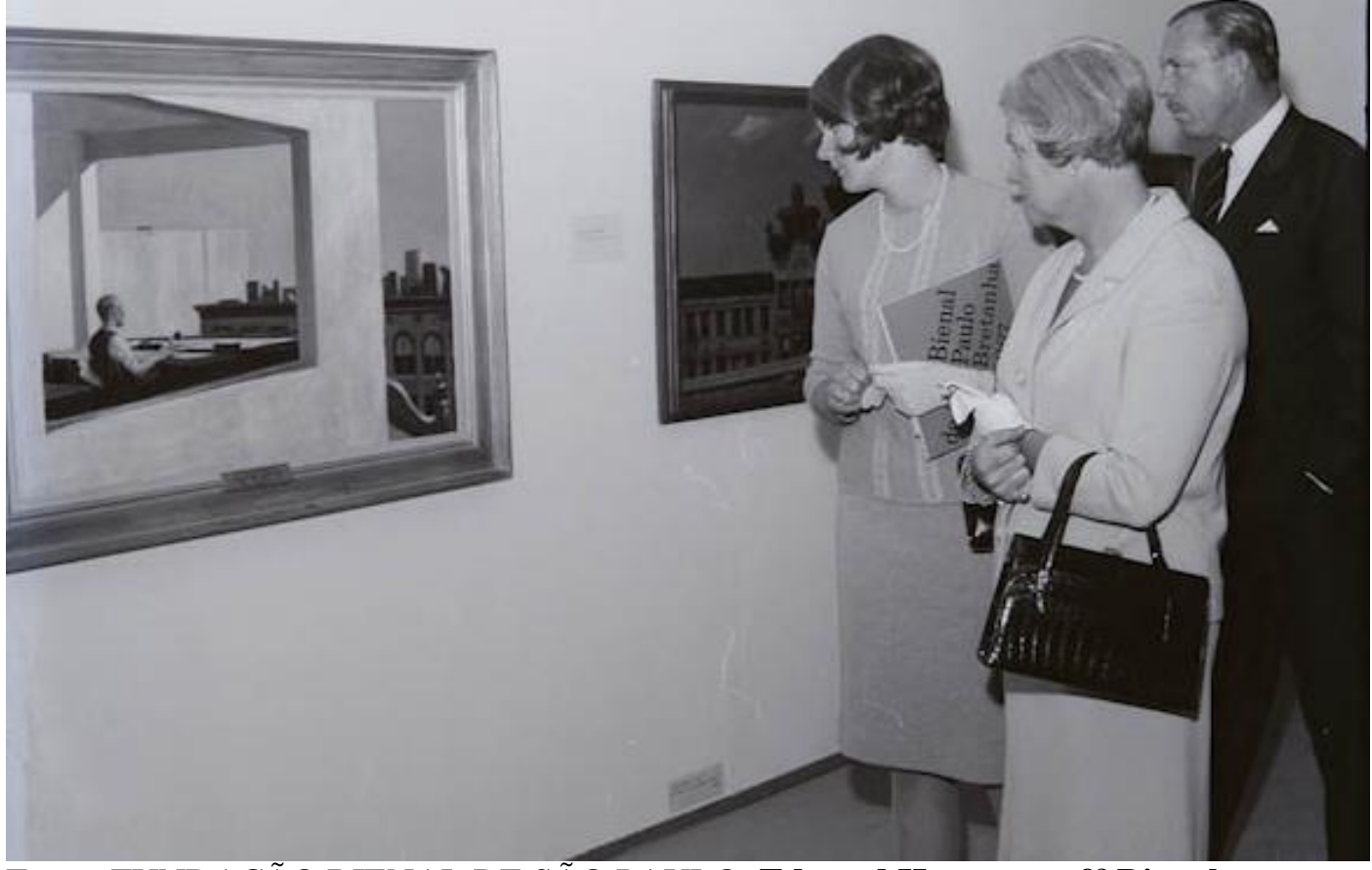

Fonte: FUNDAÇÃO BIENAL DE SÃO PAULO. Edward Hopper na 9a Bienal.

Disponível em: 〈http://www.bienal.org.br/post/364〉 Acesso em 12 jun. 2018.

Figura 29 - Sala Especial: Ambiente U.S.A - 1957/67, com a obra de James Gill, 'Marilyn'. À esquerda, intervenção do público frente ao contexto político da época. () Agencia Estado.

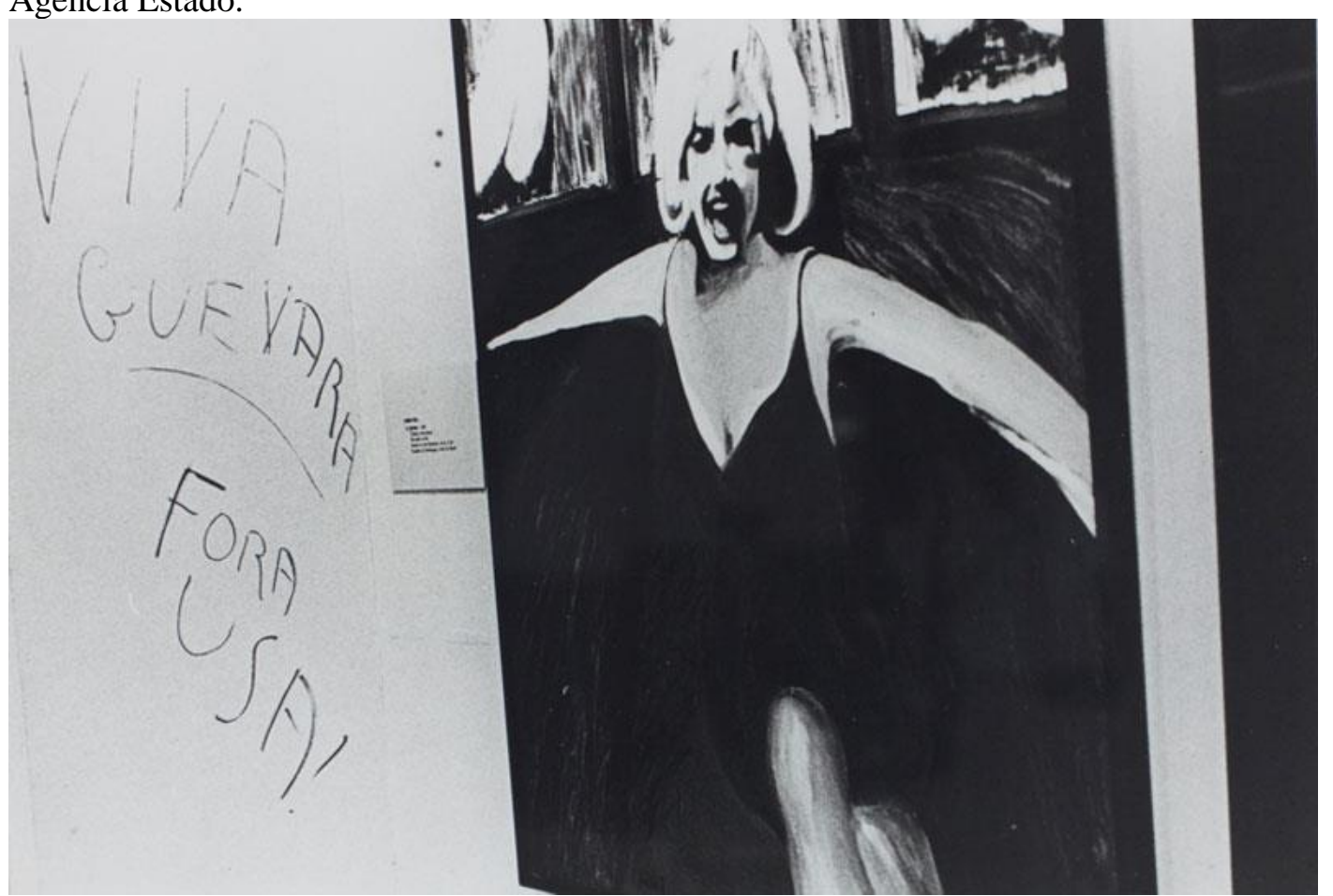

Fonte: FUNDAÇÃO BIENAL DE SÃO PAULO. 9ª Bienal de São Paulo. Disponível em: <http://www.bienal.org.br/exposicoes/9bienal/fotos/3889> Acesso em 12 jun. 2018. 
Figura 30 - Abertura da $9^{a}$ Bienal. Francisco Matarazzo Sobrinho e Mario Pedrosa em frente à obra de Robert Rauschenberg na Sala Especial: Ambiente U.S.A - 1957/67. Autor não identificado.

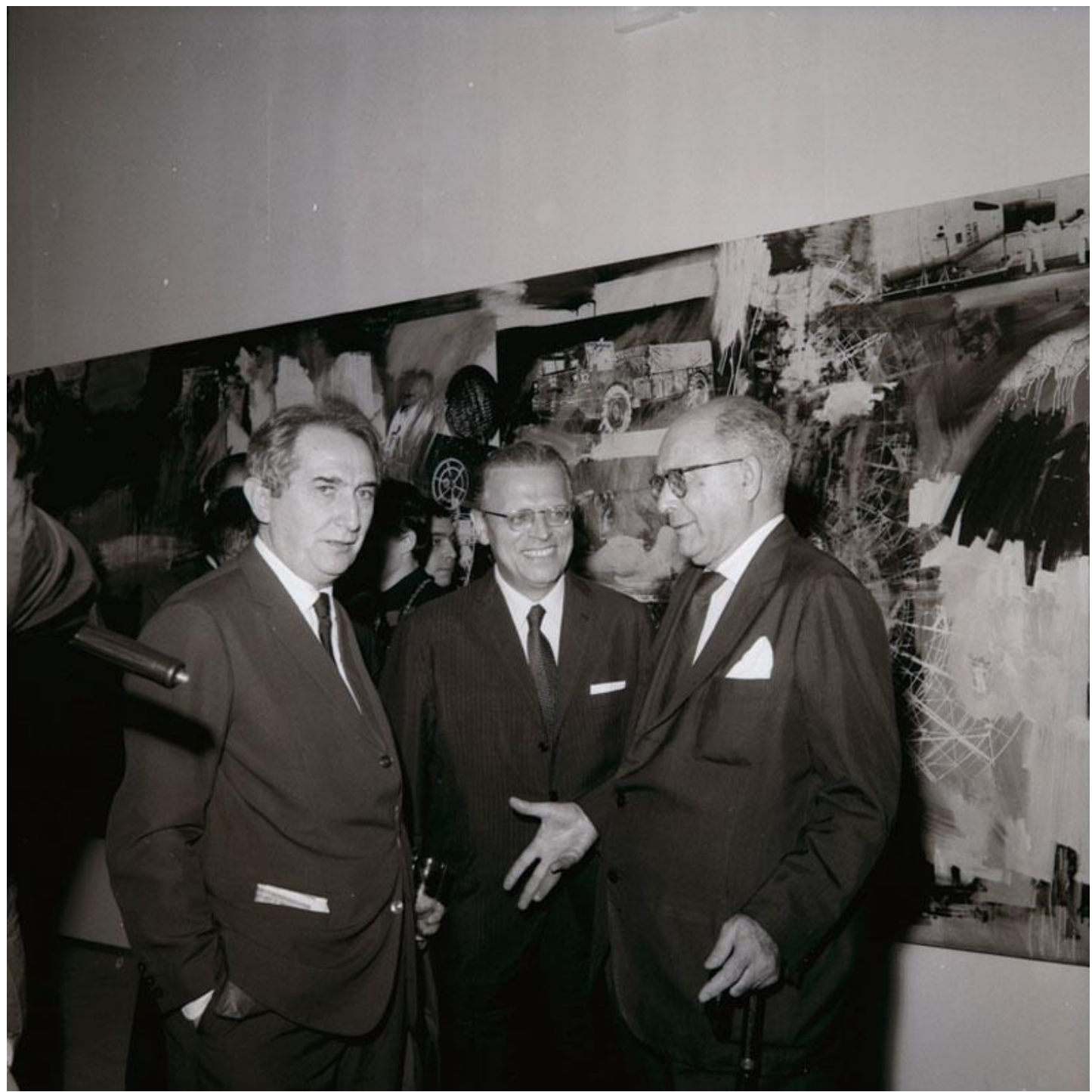

Fonte: FUNDAÇÃO BIENAL DE SÃO PAULO. 9 $^{\mathbf{a}}$ Bienal de São Paulo. Disponível em: 〈http://www.bienal.org.br/exposicoes/9bienal/fotos/3882> Acesso em 12 jun. 2018. 
Assim como na Bienal anterior, a representação brasileira foi criticada pela heterogeneidade dos trabalhos selecionados, bem como pelo grande número de artistas. Foi, nas palavras de Leonor Amarante, uma Bienal "generosa, que tinha de tudo um pouco, sem rigor conceitual" "211. Três anos mais tarde, Mario Pedrosa manifestaria sua discordância em relação à constituição das salas brasileiras, "para as quais um júri da seleção de missionário, sob a ascendência de Mário Schenberg, deixou passar tudo, o bom e o mau, o achado e o inacabado, bastando para tanto que um embrião de idéia despontasse" 212 . Contudo, havia nesse conjunto artistas jovens cuja qualidade era já então reconhecida, a saber, Wesley Duke Lee, Carlos Vergara, Nelson Leirner, José Roberto Aguilar, Cláudio Tozzi, Flávio de Carvalho, Marcelo Nietsche, José Resende, Frans Weissemann, Fayga Ostrower e Maria Bonomi.

Uma análise detida das atas das reuniões do Júris dos quais Mario Schenberg fez parte tornou possível reavaliar a imagem que se cultivava na época, a respeito da qual o crítico "deixava passar tudo"213. Nessa documentação, que registra apenas as decisões dos jurados sobre as obras que entrariam ou não nas representações brasileiras das mostras, não foi possível encontrar os debates que originaram as decisões. Contudo, os registros revelaram que, na grande maioria das vezes em que se recusavam obras, a decisão de Schenberg estava em concordância com a dos demais jurados. Os casos nos quais apenas o crítico opinava pela aceitação de uma obra, mesmo contra a decisão de seus colegas, são raros.

Sobre isso, Fábio Magalhães (2018), que integrou júris de outros eventos juntamente com o crítico, relata algo que Schenberg sempre dizia nessas ocasiões: "o grave não é deixar entrar um artista ruim, que tem uma obra fraca, o grave é nós impedirmos uma obra boa de entrar" ${ }^{\text {"14 }}$. É possível que tenha vindo daí a imagem de Mario Schenberg como um crítico que aceitava tudo. O fato é que, quando se deparava com obras que despertavam seu interesse, o crítico argumentava em favor delas,

\footnotetext{
211 AMARANTE, Leonor. As Bienais de São Paulo: 1951 a 1987. São Paulo: Projeto, 1989, p. 168. 212 PEDROSA, Mário. A Bienal de Cá para Lá. In Mundo, Homem, Arte em crise. (Org. Aracy Amaral). São Paulo: Perspectiva, 1975, p. 301.

${ }^{213}$ PEDROSA, Mário. A Bienal de Cá para Lá. In Mundo, Homem, Arte em crise. (Org. Aracy Amaral). São Paulo: Perspectiva, 1975, p. 301.

${ }^{214}$ [Informação verbal] MAGALHÃES, Fábio. Entrevista concedida a Ana Paula Cattai Pismel. São Paulo, 05 abr. 2018. 12 arquivos .MOV (1h52'22'’). [A entrevista encontra-se depositada no Centro Mario Schenberg de Documentação da Pesquisa em Arte - ECA/USP]
} 
buscando convencer os colegas do mérito do trabalho, de modo vivo, mas sempre polido $^{215}$.

O curador aponta, também, que Schenberg tinha um olhar muito atento ao analisar as obras e, por conta de sua grande vivência, além da ampla bagagem cultural e intelectual, o crítico era capaz argumentar muito fortemente. Outro ponto destacado por Fábio Magalhães (2018) é o olhar aguçado de Schenberg, atribuído pelo entrevistado não somente ao conhecimento do crítico, como principalmente à sua capacidade intuitiva: "quando ele olhava para uma obra e sabia que aquilo o interessava, aí que ele ia refletir sobre ela, mas nesse primeiro impacto da obra de arte, o Mario tinha um olhar muito preciso" 216 .

Além dessa característica de seu perfil, Caciporé Torres (2018) apontou que Mario Schenberg saia em busca de artistas jovens que merecessem uma oportunidade de participar das bienais. O artista relatou que, certa vez, o crítico o procurou na FAAP, onde dava aulas então, para saber se, entre seus alunos, havia algum que tinha talento e estava desenvolvendo um trabalho promissor. Dessa pesquisa, surgiram artistas como artistas Marcelo Nitche e Carmela Gross, que participaram pela primeira vez da Bienal de São Paulo em $1967^{217}$. Note-se que ambos os artistas integraram também a edição de 1969, permanecendo ao lado de Schenberg quando do boicote.

Desse modo, o procedimento de Schenberg era sair em busca de novos talentos de forma ativa, incentivando-os a enviarem obras para as bienais. Com isso, sua atividade não se resumia a aguardar o conjunto de obras submetidas ao júri de seleção para escolher, entre elas, as que deveria defender. Contudo, importa deixar claro, conforme observou Caciporé Torres, que a intenção de Schenberg não era fabricar novos artistas de maneira aleatória, mas identificar jovens que estivessem realizando um trabalho promissor e que mereciam uma oportunidade para mostrar seu trabalho ${ }^{218}$.

\footnotetext{
${ }^{215}$ [Informação verbal] MAGALHÃES, Fábio. Entrevista concedida a Ana Paula Cattai Pismel. São Paulo, 05 abr. 2018. 12 arquivos .MOV (1h52'22'"). [A entrevista encontra-se depositada no Centro Mario Schenberg de Documentação da Pesquisa em Arte - ECA/USP]

${ }^{216}$ [Informação verbal] MAGALHÃES, Fábio. Entrevista concedida a Ana Paula Cattai Pismel. São Paulo, 05 abr. 2018. 12 arquivos .MOV (1h52'22'"). [A entrevista encontra-se depositada no Centro Mario Schenberg de Documentação da Pesquisa em Arte - ECA/USP]

${ }^{217}$ [Informação verbal] TORRES, Caciporé. Entrevista concedida a Ana Paula Cattai Pismel. São Paulo, 08 mai. 2018. 1 arquivo .mp3 (16’39'). [A entrevista encontra-se depositada no Centro Mario Schenberg de Documentação da Pesquisa em Arte - ECA/USP]

${ }^{218}$ [Informação verbal] TORRES, Caciporé. Entrevista concedida a Ana Paula Cattai Pismel. São Paulo, 08 mai. 2018. 1 arquivo .mp3 (16'39'). [A entrevista encontra-se depositada no Centro Mario Schenberg de Documentação da Pesquisa em Arte - ECA/USP]
} 
No texto A Representação Brasileira na IX Bienal de São Paulo, Schenberg afirmou que o júri foi capaz de compreender que "o momento atual da arte brasileira se caracteriza por uma irrupção maciça de artistas jovens que encontram novos caminhos" ${ }^{219}$, refletindo com propriedade a extrema variedade de direcionamentos tomados pelos novos artistas e pelas novas tendências realistas. Observou, ainda, que a presença de objetos e esculturas foi maior que na bienal anterior, tanto pela orientação diferenciada do júri de seleção, quanto pelo aumento das pesquisas de artistas nessa direção ${ }^{220}$.

Entre os artistas sobre os quais Mario Schenberg escreveu na IX Bienal está José Roberto Aguilar, que ganhou nessa edição o Prêmio Itamaraty, com a série Gênesis (I, II, III, IV e V, 1967, esmalte sintético, $180 \times 220 \mathrm{~cm})^{221}$. Sobre o artista, o crítico observou:

José Roberto Aguilar foi um dos criadores da nova figuração na pintura brasileira com os seus olhos da época da VIII Bienal, de cunho poderosamente mágico e demoníaco. Expõe agora grandes telas pintadas a revólver em que consegue efeitos de cor surpreendentes, evocando a luminosidade do néon. É uma das personalidades marcantes da pintura brasileira, apesar de tão jovem ${ }^{222}$.

Schenberg faz considerações, também, sobre Marcelo Nitsche que, em seu entender, "surge como a figura mais poderosa da escultura objetista de tendência pop de São Paulo"223, trazendo para a IX Bienal um conjunto variado de pesquisas. Uma das obras que integraram esse conjunto foi Buum, de $1966^{224}$, pertencente a um momento no qual sua linguagem pop não tinha relação com a manifestação estrangeira dessa tendência, mas provinha de uma "vivência autêntica e profunda o ambiente da metrópole paulista, especialmente do que a caracteriza como grande centro industrial brasileiro" 225 .

\footnotetext{
${ }^{219}$ SCHENBERG, Mario. A Representação Brasileira na IX Bienal de São Paulo. In Pensando a Arte. São Paulo: Nova Stella, 1988, p. 183.

${ }^{220}$ SCHENBERG, Mario. A Representação Brasileira na IX Bienal de São Paulo. In Pensando a Arte. São Paulo: Nova Stella, 1988, p. 183.

${ }^{221}$ FUNDAÇÃO BIENAL DE SÃO PAULO. IX Bienal. (catálogo de exposição) São Paulo: Fundação Bienal, 1967, p. 96.

${ }^{222}$ SCHENBERG, Mario. A Representação Brasileira na IX Bienal de São Paulo. In Pensando a Arte. São Paulo: Nova Stella, 1988, p. 195.

${ }^{223}$ SCHENBERG, Mario. A Representação Brasileira na IX Bienal de São Paulo. In Pensando a Arte. São Paulo: Nova Stella, 1988, p. 196.

${ }^{224}$ FUNDAÇÃO BIENAL DE SÃO PAULO. IX Bienal. (catálogo de exposição) São Paulo: Fundação Bienal, 1967, p. 112.

${ }^{225}$ SCHENBERG, Mario. Marcelo Ntsche. In Pensando a Arte. São Paulo: Nova Stella, 1988, p. 41.
} 
Figura 31 - "Bum", 1966, de Marcelo Nitsche (óleo, látex e chapa galvanizada s/ duratex e madeira; 109 x 81,5 x $61 \mathrm{~cm}$ ). Coleção Pinacoteca do Estado de São Paulo.

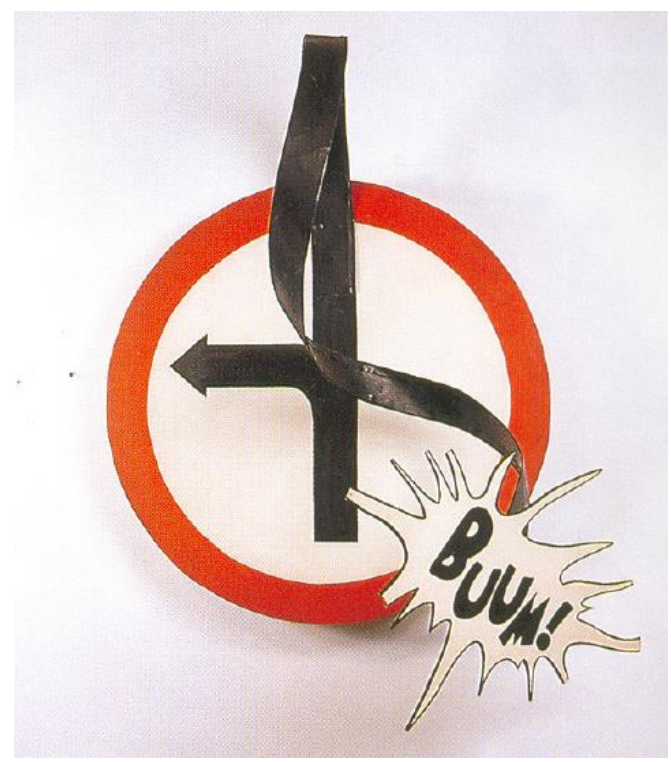

Fonte: DUARTE, Paulo Sérgio. Anos 60: transformações da arte no Brasil. Rio de Janeiro: Campos Gerais, 1998. p.224. 
Figura 32 - Gênesis IV, 1967. Esmalte sintético sobre tela, 180 x $220 \mathrm{~cm}$.

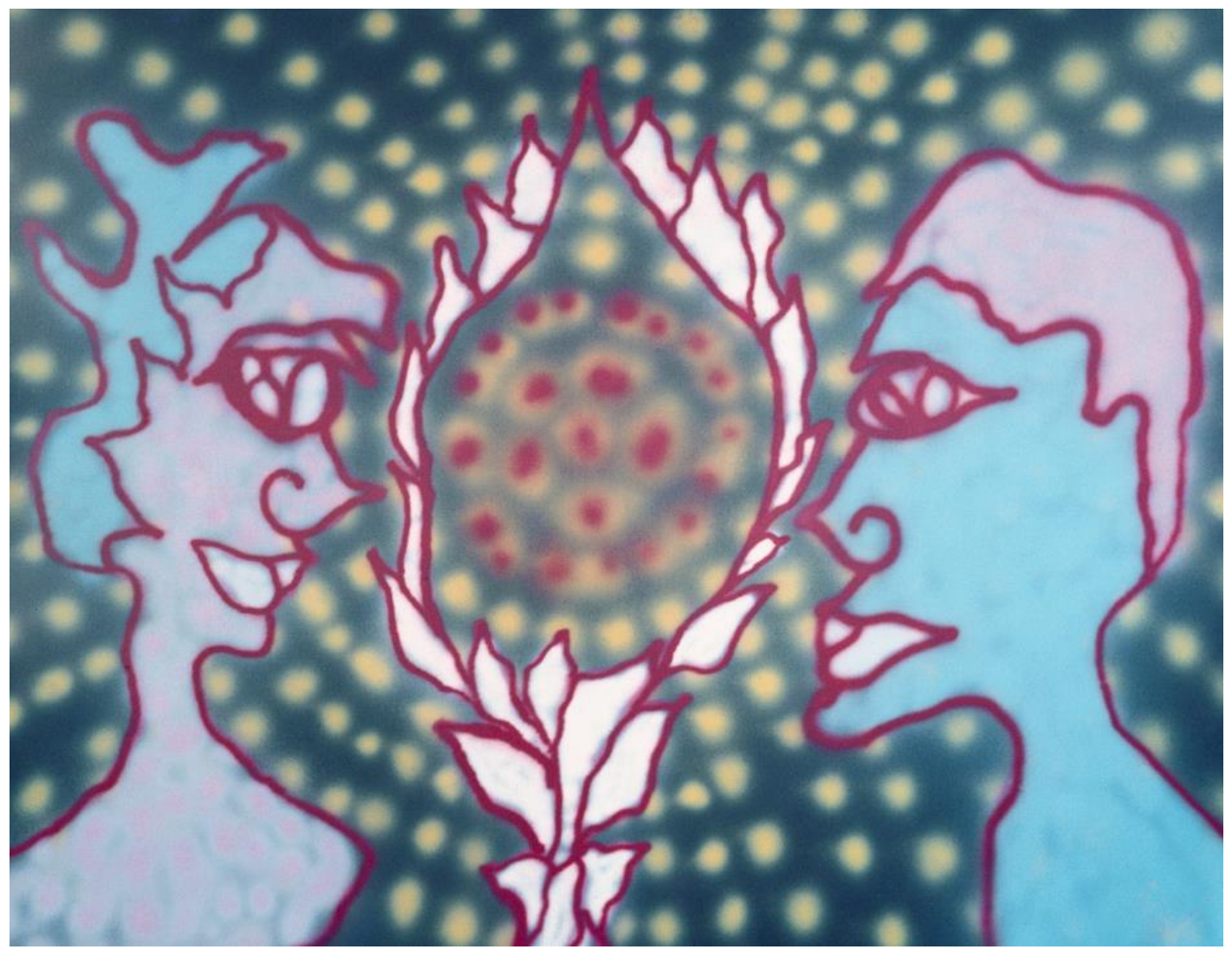

Fonte: JOSÉ ROBERTO AGUILAR. Disponível em: 〈https://joserobertoaguilar.com/> Acesso em 10 jun. 2018. 
Foi singular na história das bienais a intensidade da participação do público, que nessa edição foi como nunca antes, e não se repetiria nas mostras posteriores. A IX Bienal foi a única em que se permitiu tocar nas obras, em que houve participação do público, até mesmo em relação às obras que não tinham essa proposta. Leonor Amarante comenta que, dias depois da abertura da mostra, não se encontrava nenhuma obra intacta. "As engrenagens estavam quebradas, máquinas e motores fora de uso, interruptores e lâmpadas queimados, equipamentos de som mudos"226. Para Mario Pedrosa, a quem a participação do público agradou, isso era um sinal de que "o povo consagra a arte nova"227. O crítico observa que, na Bienal de 1967, o público compreendeu que a arte estava passando por uma profunda transformação, tornando-se algo diferente do que foi visto nas primeiras edições ${ }^{228}$.

Outra novidade foi a unificação dos prêmios: conforme um acordo assinado entre a Fundação Bienal e o Itamaraty, não haveria mais separação entre as premiações nacionais e internacionais ${ }^{229}$. Essa mudança pode ser vista como uma resposta ao momento de crise pelo qual passava a mostra, desde o Golpe Militar de 1964, que trouxe, em seu bojo, a censura. Conforme já foi apontado, não eram novidade as críticas ao sistema organizacional das bienais e, também por isso, as circunstâncias pediam mudanças.

A IX Bienal teve lugar entre 22 de setembro de 1967 e adentrou em 1968, indo até 8 de janeiro. Foi uma edição de grandes proporções, trazendo 956 artistas de 63 países, somando 4.338 obras expostas ${ }^{230}$. Tais dimensões, sobretudo relativas à representação brasileira (366 artistas, entre os quais contavam 253 estreantes), foram um dos aspectos criticados nessa edição. Critica essa, que já era tecida desde as primeiras bienais.

Esta foi a última edição do evento antes do Ato Institucional Número 5, decretado no fim de 1968 e que, no ano seguinte, causaria estragos à vida cultural do país. Antes mesmo da inauguração da mostra, algumas obras foram retiradas pelos militares, por terem-nas julgado ofensivas. Alguns jornalistas foram impedidos de

\footnotetext{
${ }^{226}$ AMARANTE, Leonor. As Bienais de São Paulo: 1951 a 1987. São Paulo: Projeto, 1989, p. 154. ${ }^{227}$ PEDROSA, Mário. A Bienal de Cá para Lá. In Mundo, Homem, Arte em crise. (Org. Aracy Amaral). São Paulo: Perspectiva, 1975, p. 301. Cf. também A Bienal e a participação...do povo, no mesmo livro. ${ }^{228}$ PEDROSA, Mário. A Bienal de Cá para Lá. In Mundo, Homem, Arte em crise. (Org. Aracy Amaral). São Paulo: Perspectiva, 1975, p. 300.

${ }^{229}$ AMARANTE, Leonor. As Bienais de São Paulo: 1951 a 1987. São Paulo: Projeto, 1989, p. 171.

${ }^{230}$ FUNDAÇÃO BIENAL. Bienal a Bienal. Disponível em: $<$ http://www.bienal.org.br/FBSP/pt/AHWS/BienalaBiena/Paginas/6BienalSaoPaulo.aspx?selected=6> Acesso em 15 jan. 2013.
} 
circular livremente pela Bienal. É interessante notar que, enquanto a obra Políptico móvel gênese do pavilhão nacional ${ }^{231}$ do artista Quissak Júnior, foi censurada por ter retrabalhado a bandeira nacional, símbolo então vetado para uso popular pelo governo; a obra Três Bandeiras, de Jasper Johns, que sobrepunha imagens da bandeira norteamericana, foi premiada ${ }^{232}$.

Com relação ao artista, merece destaque o fato de que sua participação nas bienais se deu em 1965, 1967 e 1969, período no qual Schenberg integrou o júri de seleção. Na VIII Bienal, Quissak Júnior havia obtido um feito inédito: teve todas as suas 15 obras submetidas ao júri aceitas, tornando-se o primeiro artista a participar da bienal em três categorias simultaneamente: pintura, escultura e desenho (cada uma delas com 5 obras $)^{233}$. Na IX Bienal, além da obra Políptico móvel gênese do pavilhão nacional, o artista apresentou uma série de pinturas intituladas Bandeira Brasileira, nas quais também utilizava as cores da bandeira nacional. Sobre o artista, Mario Schenberg escreveu: “Ernesto Quissak Júnior foi uma revelação da VIII Bienal. Sua pintura atual tem um interesse especial" ${ }^{\text {234 }}$. É possível que o interesse do crítico na obra do artista tenha relação com um tema ao qual ambos davam muita relevância: o humanismo ${ }^{235}$.

231 A obra Pólípticos Móveis da Gênese da Bandeira Nacional, constituída por um conjunto de esculturas e desenhos, que tem quase trinta metros de comprimento foi adquirida pelo governo de São Paulo e ficou no anfiteatro do Palácio Bandeirantes. Depois disso, ficou desaparecida até 1985, ano em que se concretizou a redemocratização. Em 2006 a obra foi para o Memorial da América Latina, na cidade de São Paulo. Cf. DICIONÁRIO DE ARTISTAS DO BRASIL. Verbete Quissak Júnior. Disponível em $\langle$ http://www.brasilartesenciclopedias.com.br/nacional/quissak_junior.htm\#fotos>Acesso em: 12 jun. 2018.

${ }^{232}$ AMARANTE, Leonor. As Bienais de São Paulo: 1951 a 1987. São Paulo: Projeto, 1989, p. 157.

${ }^{233}$ Jovem remeteu 15 obras para a Bienal: as 15 foram aceitas. Notícias Populares, São Paulo (Capital), 01/07/1965.

${ }^{234}$ SHCENBERG, Mario. A representação brasileira na IX Bienal de São Paulo. In Pensando a Arte, São Paulo: Nova Stella, 1988, p. 196.

${ }^{235} \mathrm{Na}$ dissertação intitulada Schenberg: em busca de um Novo Humanismo, foi estudada a visão de Mario Schenberg a esse respeito. Cf. Pismel, 2013. 
Figura 33 - Quissak Júnior, Sem título, 1978. Óleo sobre tela, $59.00 \mathrm{~cm}$ x $75.00 \mathrm{~cm}$.

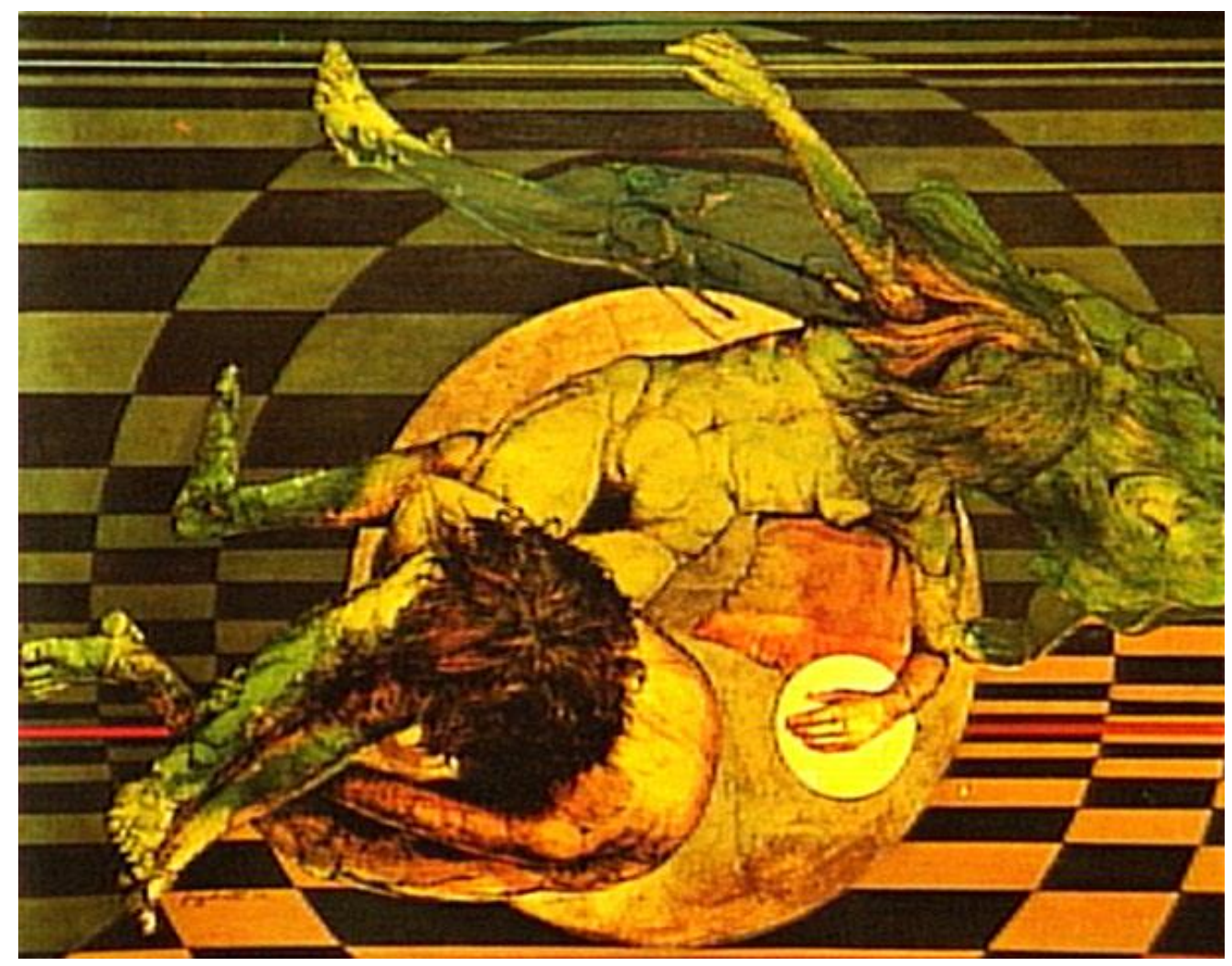

Fonte: SEM Título. In: ENCICLOPÉDIA Itaú Cultural de Arte e Cultura Brasileiras. São Paulo: Itaú Cultural, 2018. Disponível em: 〈http://enciclopedia.itaucultural.org.br/obra11889/sem-titulo〉. Acesso em: 12 de Jun. 2018. 
Figura 34 - Jasper Johns, Três Bandeiras, 1958. Encaustica sobre tela, $78.42 \mathrm{~cm} \times$ $115.5 \mathrm{~cm}$, Whitney Museum of American Art, Nova York.

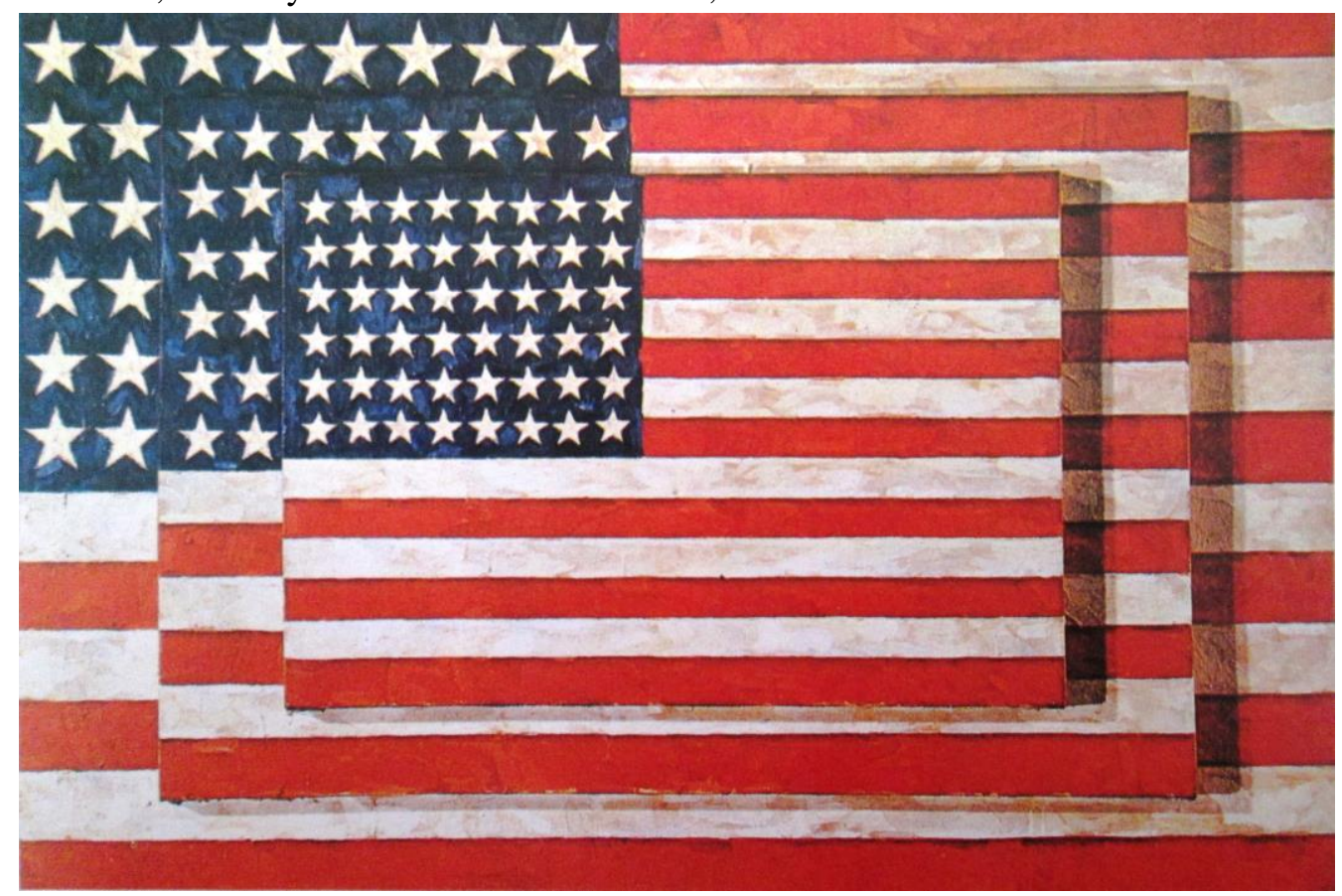

Fonte: AMARANTE, 1989, p. 159.

Figura 35 - Quissak Júnior, Políptico Móvel Um ou do Campo Verde, Políptico Móvel Dois ou do Losango Amarelo, Políptico Móvel Três ou do Círculo Azul, Políptico Móvel Quatro ou da Faixa Branca, Políptico Móvel Cinco ou da Pátria. 1967, óleo sobre tela.

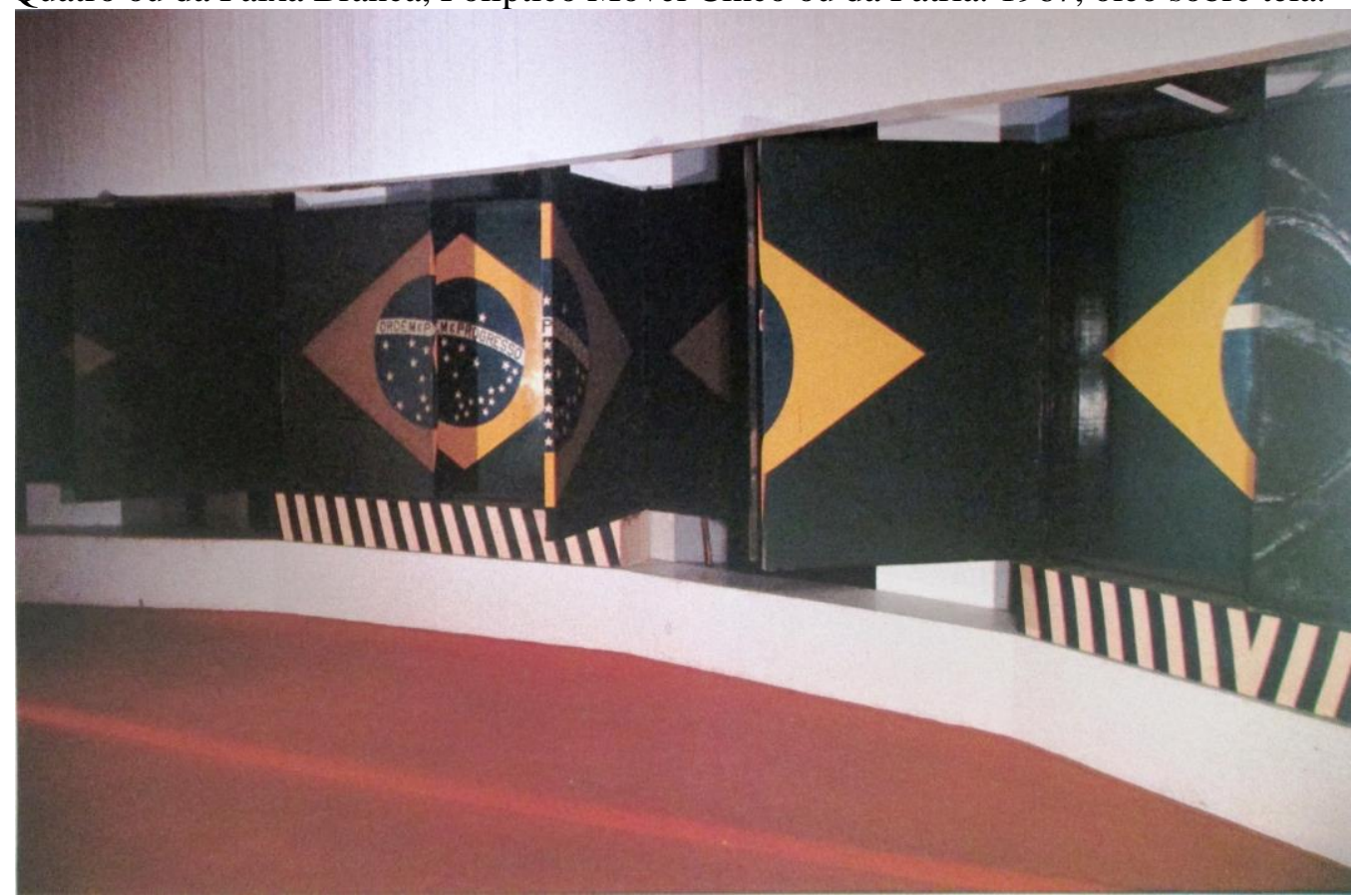

Fonte: AMARANTE, 1989, p. 158. 
O Júri de Seleção da IX Bienal de São Paulo foi constituído por dois nomes indicados pela Diretoria Executiva da Fundação Bienal, dois escolhidos pelos artistas por meio de votação e um quinto, escolhido por esses quatro. Novamente, o direito a voto cabia apenas aos artistas que já tinham sido aceitos em pelo menos uma Bienal anterior. Cada um deles deveria indicar, no ato da inscrição, dois nomes de críticos de arte, em ficha fornecida pela Bienal ${ }^{236}$. A apuração não sofreu mudanças em relação à edição anterior. Assim, o corpo de jurados foi integrado por: José Geraldo Vieira e Mario Schenberg (eleitos pelos artistas, aquele com 41 votos, esse com 32) ${ }^{237}$, Geraldo Ferraz e Jayme Maurício (indicados pela Fundação Bienal), Clarival Valadares (escolhido pelos quatro).

Diferente do regulamento da edição anterior, no qual eram elegíveis não apenas críticos de arte, mas também artistas (Regulamento da VIII Bienal, Art. $5^{\circ}$ ), na IX Bienal apenas críticos de arte poderiam ser votados para integrar o Júri de Seleção (Regulamento da IX Bienal, Art. 4º). Na edição seguinte, em 1969, seria ainda mais enfatizada a exigência de que todos os membros do Júri deveriam ser críticos de arte, na medida em que essa informação foi destacada num subitem exclusivo a esse respeito (conforme o Regulamento da X Bienal, Capítulo II, item V, subitem $a)^{238}$.

Se por um lado, as mudanças na conformação do Júri de Seleção, expressas nas sucessivas alterações dos regulamentos, enfatizam a posição de que as obras inscritas pelos artistas seriam julgadas com mais propriedade por críticos de arte que por outros artistas; por outro, em nenhum momento a Fundação Bienal define o que entende por crítico de arte.

É a partir dessa indefinição que surge a polêmica em torno da aceitação de Mario Schenberg como membro do Júri de Seleção nas edições das quais participou, pois apesar de ser considerado como tal pelos artistas, seu nome foi recebido com dúvidas pela Fundação Bienal. Na ocasião, Luíz Rodrigues Alves, então diretor da Bienal, fez restrições à indicação do professor Schenberg, devido ao fato de ele não assinar

\footnotetext{
${ }^{236}$ FUNDAÇÃO BIENAL. IX Bienal. (catálogo de exposição) São Paulo: Fundação Bienal, 1967, s.p. ${ }^{237}$ MAURÍCIO, Jayme. Bienal: eleitos dos artistas. Correio da Manhã, 06/06/67.

${ }^{238}$ FUNDAÇÃ̃O BIENAL. VIII Bienal. (catálogo de exposição) São Paulo: Fundação Bienal, 1965, Regulamento: Capítulo II, Artigo 5 ${ }^{\circ}$, p.20. FUNDAÇÃO BIENAL. IX Bienal. (catálogo de exposição) São Paulo: Fundação Bienal, 1967. Regulamento: Capítulo II, Artigo 4º s.p. FUNDAÇÃO BIENAL. X Bienal. (catálogo de exposição) São Paulo: Fundação Bienal,1969. Regulamento: Capítulo II, V, $a$, p. 449.
} 
nenhuma coluna em jornal, e também por conta de sua situação política, posição que desmentiu logo em seguida, tendo sido respeitado o resultado da eleição ${ }^{239}$.

De fato, o incidente com relação à eleição de Mario Schenberg trouxe à tona essa demanda que há tempos era feita por artistas e críticos. A tentativa de definir como crítico de arte o profissional que mantinha colunas em jornais, contudo, não pareceu ter caído muito bem nesse caso, conforme ficou evidente pelo posicionamento dos artistas presentes na apuração dos votos, que saíram em defesa do crítico $^{240}$. Sobre isso, o próprio Schenberg ${ }^{241}$ diria anos mais tarde:

Eu, que já tinha organizado a primeira exposição de Volpi em 1944, organizei em 61 a sua primeira retrospectiva. Depois disso, começaram a votar para que eu fizesse parte dos júris de seleção das Bienais. O primeiro júri que integrei foi em 1965, depois 67 e 69 . E, a partir daí, a Bienal me aplica o Ato 75. Mas antes disso, já em 67, ganhei a eleição por maioria e quiseram me impugnar, alegando que eu não era crítico de arte, que não escrevia em jornal, coisa de que, aliás, nunca gostei. Sempre preferi escrever esporadicamente. Mas, finalmente, tiveram que recuar, porque fui aceito pela Associação dos Críticos de Arte. Também a Associação de Artistas Plásticos firmou posição a meu favor.

Nessa ocasião, Schenberg recebeu não só o apoio da Associação Internacional de Artistas Plásticos (cujo presidente era o artista Maurício Nogueira Lima), mas também o da Associação Internacional de Críticos de Arte, que o aceitou em seus quadros. Tal fato é significativo, pois evidenciou o prestígio que o crítico angariou junto aos artistas e ao respeito que passou a obter junto a muitos críticos de arte. Com isso, seu nome foi legitimado, tornando essa polêmica um caso superado.

A participação de Schenberg nas Bienais se deu por força de sua atuação junto aos artistas, os quais confiavam em sua atuação e acreditavam que ele poderia defender seus interesses junto ao júri do evento ${ }^{242}$. Da parte da maioria de outros críticos, por muito tempo, ele se deparou com um certo distanciamento, em parte devido à sua formação e metodologia peculiar, em parte devido ao seu posicionamento político.

Segundo afirma a pesquisadora Alecsandra Matias de Oliveira em Schenberg: Crítica e Criação, os lugares de divulgação da arte, para o crítico, eram os meios especializados, como galerias, catálogos e álbuns de artistas, além do ambiente

\footnotetext{
${ }^{239}$ Schenberg fica. Correio da Manhã, 06 jun. 1967.

${ }^{240}$ Artistas a favor do crítico, s/p, s/d, sem identificação de jornal.

${ }^{241}$ SCHENBERG, Mario. Depoimento. In AJZNBERG, Elza. Schenberg - Arte e Ciência. São Paulo: ECA/USP, 1995, p. 142.

${ }^{242}$ OLIVEIRA, Alecsandra Matias de. Schenberg: crítica e criação. São Paulo: EDUSP, 2010.
} 
universitário. Schenberg não tinha acesso a jornais e revistas: sendo físico, era objeto de preconceito por parte dos demais críticos de arte, geralmente literatos ou ligados às ciências humanas. Além disso, se outros críticos de arte mantinham seu posicionamento político de modo a não prejudicar seu relacionamento com a imprensa, as ideias de Schenberg, em sua especificidade, não eram vistas como passíveis de veiculação periódica, pois o físico era um "incontrolável marxista, mesmo para os colegas de doutrina",243.

Retomando: um dos motivos para a tentativa de impugnar sua participação no Júri das bienais foi a alegação de que ele não escrevia em jornais. É possível constatar que Mario Schenberg não concordava com esse requisito, pois não o via como condição necessária (nem suficiente) para o exercício da crítica de arte. Se o que conferia a alguém a competência para tal atividade era a formação teórica adequada, então era perfeitamente possível que houvesse críticos que não escrevessem em jornais e, principalmente, que houvesse pessoas que escrevessem em jornais sem ter a competência para tanto. A esse respeito, Schenberg ${ }^{244}$ afirmou o seguinte:

Aqui no Brasil, as exigências em relação ao crítico de arte são muito pequenas, de modo que qualquer pessoa que tenha algumas ideias sobre arte, algumas experiências de arte, já é considerado um crítico. Mas acho necessário superar esse período, eu acho necessário haver uma crítica de arte baseada em outros critérios que não seja simplesmente o de escrever em jornais.

Schenberg não se considerava um crítico de arte, pois não julgava ter $o$ embasamento necessário a tal atividade, uma vez que seus estudos sobre Filosofia e Teoria da Arte tinham se dado esporadicamente, por meio de leituras motivadas pela curiosidade: "Nunca me coloquei como crítico de arte, outros é que disseram que eu era [... $]^{\nsupseteq 245}$. Enquanto acadêmico, dava muita importância à formação teórica requerida para tanto e, como sua aproximação com a arte foi menos disciplinada que com a ciência, não considerava ter o embasamento que julgava necessário ao exercício da crítica de $\operatorname{arte}^{246}$.

\footnotetext{
${ }^{243}$ OLIVEIRA, Alecsandra Matias de. Schenberg: crítica e criação. São Paulo: EDUSP, 2010, p. 83-4. ${ }^{244}$ SCHENBERG, Mario. Entrevista com Mário Schenberg. (Publicada originalmente na Revista Trans/Form/Ação, v. 3, p. 6-62, 1980). In Trans/Form/Ação. Marília, v.34, 2011. Edição Especial, p. 155.

${ }^{245}$ SCHENBERG, Mario. Entrevista com Mário Schenberg. (Publicada originalmente na Revista Trans/Form/Ação, v. 3, p. 6-62, 1980). In Trans/Form/Ação. Marília, v.34, 2011. Edição Especial, p. 154.

${ }^{246}$ GOLDFARB, José Luiz. Voar também é com os Homens. São Paulo: EDUSP, 1994, p.127.
} 
É claro que nem todos os críticos da época se enquadravam na objeção feita por Schenberg à ideia pré-concebida de que manter colunas em jornais fazia de alguém crítico de arte. Mas pode-se ver que, em seu entender, essa concepção corrente do crítico de arte era prejudicial ao desenvolvimento da arte no país.

Outra movimentação da organização da IX Bienal foi o projeto das pré-bienais, ou seja, bienais nacionais que aconteceriam nos anos pares, com a finalidade de selecionar melhor a representação brasileira a ser levada para as bienais internacionais ${ }^{247}$. Em setembro de 1970, seria inaugurada a primeira Bienal Nacional, que teve o mérito de ir além do eixo Rio-São Paulo, reunindo artistas de 19 estados do país. O evento teria outras edições: em 1972, 1974 e 1976. Em 1978, foi substituído pela Bienal Latino-Americana que, apesar de projetada para ser sazonal, teve apenas uma edição $^{248}$.

Pode-se dizer que ideia da Pré-Bienal se colocava como resposta às críticas ao gigantismo da representação brasileira, tecidas desde as primeiras bienais. Em lugar de expor um número reduzido de trabalhos de inúmeros artistas, a seleção por meio das pré-bienais objetivava mudar esse padrão, selecionando menos artistas, mas exibindo um conjunto de obras amplo o suficiente para dar a ver a trajetória da pesquisa de cada um deles.

Com relação a isso, é importante observar que Mario Schenberg foi contrário ao novo sistema de seleção pelas pré-bienais, pois isso dificultaria a participação de novos artistas nas bienais internacionais. Segundo Schenberg ${ }^{249}$,

[c]om uma seleção de trabalhos, feita pela pré-Bienal, somente os artistas já consagrados acabariam participando da Bienal Internacional. Ninguém teria a coragem de excluir obras de artistas experientes e renomados para colocar em seu lugar um desconhecido, mesmo que o trabalho seja melhor.

Essa citação, feita por Leonor Amarante no livro As Bienais de São Paulo: 1951 a 1987. Fábio Magalhães (2018) ${ }^{250}$, corroborou o posicionamento do crítico com relação

\footnotetext{
${ }^{247}$ Foi encontrado o rascunho do regulamento do que seria a mostra Plástica 69, a ser realizada no primeiro semestre do ano que lhe dá nome, já com a configuração das bienais nacionais, cujo início se daria apenas em 1970. (Arquivo Histórico Wanda Svevo, Fundação Bienal).

${ }^{248}$ AMARANTE, Leonor. As Bienais de São Paulo: 1951 a 1987. São Paulo: Projeto, 1989.

${ }^{249}$ Depoimento de Mario Schenberg, apud AMARANTE, Leonor. As Bienais de São Paulo: 1951 a 1987. São Paulo: Projeto, 1989, p 179.

250 [Informação verbal] MAGALHÃES, Fábio. Entrevista concedida a Ana Paula Cattai Pismel. São Paulo, 05 abr. 2018. 12 arquivos .MOV (1h52'22')). [A entrevista encontra-se depositada no Centro Mario Schenberg de Documentação da Pesquisa em Arte - ECA/USP]
} 
às Pré-Bienais, acrescentando que provavelmente Schenberg teria participado desse novo modo de seleção da representação brasileira, mesmo que não estivesse de acordo com ela. Nesse caso, como os eventos têm início num momento em que o crítico se vê afastado das bienais, não houve possibilidade de participação.

De qualquer modo, o posicionamento de Mario Schenberg está alinhado com o incentivo que dedicou aos artistas jovens, como foi próprio de sua atuação enquanto crítico de arte, principalmente nos anos de 1960 e 1970. Para Schenberg, a realização de uma bienal nacional, ou pré-bienal, seria prejudicial ao próprio intento da mostra: apresentar as tendências mais recentes das artes plásticas. Quanto mais etapas fossem interpostas entre o artista iniciante e a Bienal de Arte de São Paulo, mais difícil seria para ele vencer o renome de seus colegas com carreiras já consolidadas.

Ao escrever sobre a IX Bienal de São Paulo, o crítico afirmou que "o maior mérito do júri da seleção [...] foi ter compreendido o momento revolucionário atual da arte brasileira e de ter dado prioridade às inovações, mesmo quando apresentadas em obras com deficiências de execução" ${ }^{251}$. O crítico destacou, ainda, a relevância da compreensão de que a qualidade dizia respeito à "riqueza de concepção experimental e de intuição pioneira", e não simplesmente à dimensão artesanal do acabamento da obra de arte. Nesse sentido, as obras selecionadas para a IX Bienal de São Paulo, segundo Schenberg, teriam dado uma "imagem impressionante da vitalidade do movimento artístico brasileiro atual"252.

${ }^{251}$ SCHENBERG, Mario. Pensando a Arte, São Paulo: Nova Stella, 1988, p. 194.

${ }^{252}$ SCHENBERG, Mario. Pensando a Arte, São Paulo: Nova Stella, 1988, p. 196. 
As deficiências de execução foram atribuídas à grande quantidade de artistas jovens entre os participantes da exposição. Contudo, a juventude, e até a "inexperiência", foram vistas justamente como um dos impulsos dos artistas na direção de novos caminhos: em nome da inovação das propostas que apresentam, Schenberg relevou tais falhas. Isso porque, para ele, a diversidade de artistas e de suas pesquisas era muito animadora.

O motivo para isso foi a ênfase dada à proposta, ao conceito apresentado pelo artista, e não apenas à obra de arte em seu aspecto técnico de execução. Seu valor formal intrínseco, enquanto princípio interno, não era mais o foco da análise crítica, mas a intencionalidade da poética e da proposição que o cercava e lhe atribuía
Figura 36 - Hélio Oiticica, B15 Bólide Vidro 4 - Terra, 1964, cuba de vidro, terra e tecido. Projeto Hélio Oiticica (Rio de Janeiro, RJ). Reprodução fotográfica autoria desconhecida.

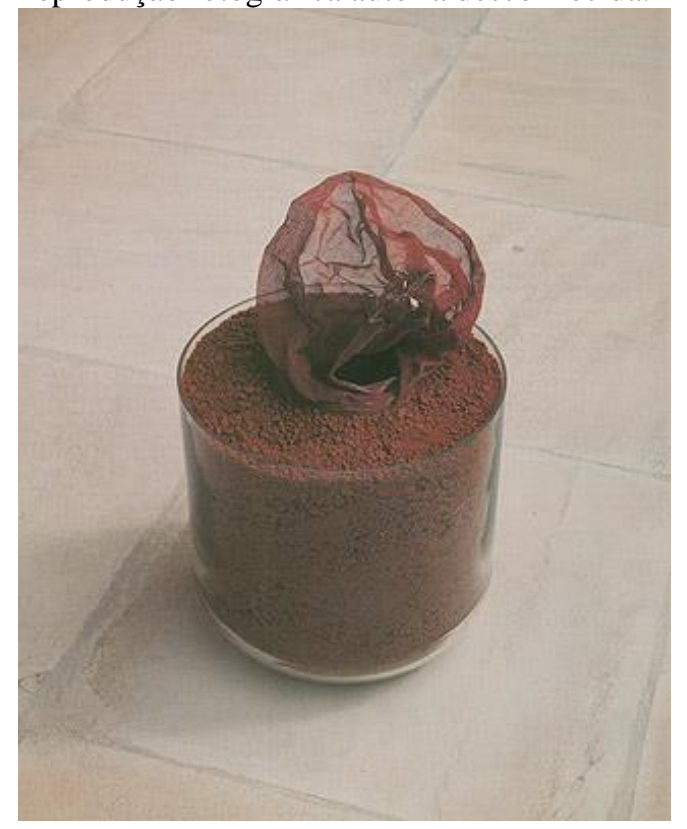

Fonte: B15 Bólide Vidro 4 - Terra. In: ENCICLOPÉDIA Itaú Cultural de Arte e Cultura Brasileiras. São Paulo: Itaú Cultural, $2018 . \quad$ Disponível em: $<$ http://enciclopedia.itaucultural.org.br/obra488 6/b15-bolide-vidro-4-terra>. Acesso em: 12 de Jun. 2018.

sentido. O questionamento artístico, social ou político presente na obra passou a fazer parte de sua conformação, e seu fundamento se localiza além dela, na linguagem ${ }^{253}$.

Mario Schenberg, que havia enfrentado duros embates na assembleia legislativa na década de $1940^{254}$, não se furtou de defender com a mesma firmeza o acesso dos artistas e o espaço da delegação brasileira na Bienal. Em meio dos diversos entraves enfrentados, tanto interna quanto externamente à organização das Bienais, o

\footnotetext{
${ }^{253}$ Daí decorre a importância dos textos escritos pelos artistas, que se tornaram comuns a partir da década de 1960, na medida em que mostravam os fundamentos conceituais das obras e tornavam claros os questionamentos por elas apresentados. Alguns dos artistas que fizeram isso com frequência foram Hélio Oiticica, Lygia Clark, Waldemar Cordeiro e Frederico Morais (sendo que os dois últimos atuavam também como críticos de arte). Cf. FERREIRA, Glória \& COTRIM, Cecília (seleção e comentários). Escritos de artistas: anos 60/70. Tradução de Pedro Süssekind... et al. - 2. Ed. - Rio de Janeiro: Jorge Zahar Ed., 2009. Na Mesa Redonda de críticos de arte promovida na XI Bienal, em 1971, Mario Schenberg fará considerações importantes sobre o assunto, chamando a atenção da Fundação Bienal para as mudanças profundas ocorridas na arte durante a década de 1960. Mudanças essas que não excluíam as técnicas chamadas tradicionais, mas demandavam a atualização da organização das bienais que, em seu entender, não estava acompanhando essas transformações (Arquivo Wanda Svevo, Fundação Bienal).

${ }^{254}$ KINHSHITA, Dina Lida. Mario Schenberg: o cientista e o político. Brasília: Fundação Astrogildo Pereira, 2014.
} 
crítico não teve receio de defender novos paradigmas emergentes na arte e os novos artistas que desenhavam tendências em gestação.

Nas três edições do certame em que fez parte do Júri de Seleção, teve em mente a necessidade de dar visibilidade a artistas iniciantes que tinham propostas inovadoras, mesmo que, em termos técnicos, suas obras deixassem a desejar. Observe-se que, por conta da firmeza do posicionamento de Mario Schenberg, os artistas primitivos puderam figurar na IX Bienal:

Em 1967, os outros membros do júri da Bienal não queriam aceitar primitivos na mostra mas Mario protestou dizendo ser isso contra os estatutos da organização e, devido a este protesto puderam entrar vários grandes primitivos como Waldomiro de Deus, Chico da Silva e José Antônio da Silva, que hoje estão entre os mais conhecidos do mundo. ${ }^{255}$

Na década de 1960, o crítico manteve proximidade com os artistas primitivos, entre eles, os citados acima. Sem dúvida, esses e outros artistas de tendências diferentes ainda em gestação foram aceitos por conta da abertura do crítico à nova realidade artística.

Segundo o que foi registrado na ata da reunião do júri de seleção em 04 de julho de $1967^{256}$, por determinação de todos os membros (a saber, Jayme Maurício, José Geraldo Vieira, Geraldo Ferraz, Mario Schenberg e Clarival do Prado Valadares), após a reunião de seleção do dia 26 de junho, Francisco Matarazzo Sobrinho convidou todos à sala da diretoria, na Fundação Bienal. Nessa ocasião, Ciccillo teria advertido os membros do júri de que não concordaria com as restrições impostas no sentido de excluir as obras de artistas ditos primitivos, destacando que apenas Mario Schenberg não as havia colocado. Para o presidente da Bienal, isso caracterizava um posicionamento preconceituoso para com uma tendência. A decisão do júri chegou ao conhecimento de Ciccillo por meio de Jayme Maurício, pois este o informou de que havia a intenção de se organizar uma sala especial de arte primitiva brasileira na pré-bienal ${ }^{257}$, que seria confiada a Clarival do Prado Valadares, Mario Schenberg e Ariano Suassuna.

${ }^{255}$ LUYTEN, Jos Mario Schenberg, amigo dos artistas. Jornal A Gazeta. São Paulo, 10 jun. 1972, pág. 9.

${ }^{256}$ Ata da reunião do júri de seleção, dia 04 jul, 1967, p. 1. Arquivo Histórico Wanda Svevo, Fundação Bienal.

${ }^{257}$ Havia planos de que fosse realizada uma pré-bienal já em 1968, o que não se concretizou. Cf. AMARANTE, Leonor. As Bienais de São Paulo: 1951 a 1987. São Paulo: Projeto, 1989. 
Geraldo Ferraz, que não se conformou com a atitude de Ciccillo, pediu demissão do júri, mas reconsiderou sua decisão após a resolução do conflito. José Geraldo Vieira e Clarival Valadares explicaram que o posicionamento dos quatro jurados, salvo Schenberg, tinha sido efetivado no Rio de Janeiro ${ }^{258}$, diante da aparente precariedade das obras submetidas à exame. Os dois críticos apelaram, ainda, para que a bienal considerasse a possibilidade de se fazer uma exposição desse gênero sob a responsabilidade de uma comissão de seleção que pudesse se deslocar pelo país, indo em busca de obras mais representativas e chegando aos artistas primitivos que não tinham acesso à bienal.

Contudo, quando foram retomados os trabalhos do júri, ficou decidido que seria feita uma reavaliação das obras dos artistas primitivos anteriormente excluídas, sendo que Jayme Maurício e Geraldo Ferraz se abstiveram de tomar parte da votação, por conta da posição que vinham sustentando até então. O novo critério adotado pelo júri ficou registrado nos seguintes termos: "o caráter experimental e inovador das obras apresentadas sem desconhecer a significação de outros valores" 259 .

Note-se que Mario Schenberg não concordou com os demais jurados quando estes decidiram excluir da seleção os artistas primitivos mas, sendo voto vencido, seguiu participando dos trabalhos. Isso é interessante, pois mostra que nem sempre, o crítico tinha sucesso em persuadir seus colegas a respeito das obras que considerava ter lugar na bienal. Embora não se possa afirmar que Schenberg tivesse defendido especificamente os artistas primitivos que depois foram aceitos, é certo que crítico não concordou com a decisão de cortar uma tendência, principalmente sob o pretexto de que as obras não estariam à altura da bienal.

A respeito da abertura de Schenberg às diferentes manifestações artísticas, é interessante o que coloca Anésia Pacheco ${ }^{260}$ :

No quadro geral da crítica brasileira, Mario Schenberg se destacava. Não apenas pela inteligência e cultura (outros críticos também foram ou são inteligentes e cultos), mas pelo pluralismo. Num meio artístico limitado, onde todos procuram fazer sua pequena reserva de mercado, prendendo-se a uma determinada forma de arte que lhe rende divisas,

\footnotetext{
${ }^{258}$ Entre os dias 16 de junho e 4 de julho, o júri funcionou em Belo Horizonte, Rio de Janeiro e São Paulo, tendo sido feitas as reuniões de escolha das obras nessas três cidades.

${ }^{259}$ Ata da reunião do júri de seleção, dia 04 jul. 1967, p. 2. Arquivo Histórico Wanda Svevo, Fundação Bienal.

${ }^{260}$ PACHECO, Anésia. Mario Schenberg: crítico de arte. REVISTA USP, São Paulo, n. 52, p. 113-114, dezembro/fevereiro 2001-2002, p. 114.
} 
Mario optou pela liberdade. Ousou, no ambiente artístico acanhado onde ousar é arriscar-se, o que a maioria teme fazer.

Mario Schenberg, ao mesmo tempo em que dialogava com artistas que estavam situados na vanguarda, também voltava seu olhar para a arte brasileira em suas diversas manifestações, por isso, Ciccillo Matarazzo apreciava sua contribuição no júri de seleção e apoiava sua atuação ${ }^{261}$. Como resultado desse ajuste de percurso do júri de seleção, foram aceitos três artistas primitivos na IX Bienal, a saber, Chico da Silva, José Antônio da Silva e Waldomiro de Deus Souza.

Entretanto, apesar de ter se mantido aberto em relação aos artistas primitivos nessa ocasião, Schenberg não a introduziu nas bienais, haja vista a participação de Heitor dos Prazeres na I Bienal, em 1951. O artista não apenas foi aceito, como recebeu o terceiro prêmio para artistas nacionais, com a tela Moenda, de um júri de premiação em que estava o crítico e historiador Herbert Read, nome extremamente respeitado na historiografia da arte mundial. Na II Bienal, Heitor dos Prazeres ganha uma sala especial $^{262}$. Se, desde o início da trajetória das bienais internacionais, essa tendência já era reconhecida, fazia pouquíssimo sentido deixar de lado os primitivos na bienal de 1967.

${ }^{261}$ BONOMI, Maria. Entrevista concedida a Ana Paula Cattai Pismel. São Paulo, 16 mai. 2018. 4 arquivos .mp3 (1h46'15' '). [A entrevista encontra-se depositada no Centro Mario Schenberg de Documentação da Pesquisa em Arte - ECA/USP]; MAGALHÃES, Fábio. Entrevista concedida a Ana Paula Cattai Pismel. São Paulo, 05 abr. 2018. 12 arquivos .MOV (1h52'22'’). [A entrevista encontra-se depositada no Centro Mario Schenberg de Documentação da Pesquisa em Arte - ECA/USP].

${ }^{262}$ HEITOR dos Prazeres. In: ENCICLOPÉDIA Itaú Cultural de Arte e Cultura Brasileiras. São Paulo: Itaú Cultural, 2018. Disponível em: <http://enciclopedia.itaucultural.org.br/pessoa10428/heitor-dos-prazeres>. Acesso em: 10 de Jun. 2018. Verbete da Enciclopédia. ISBN: 978-85-7979-060-7. 
Figura 37 - Heitor dos Prazeres, Moenda, 1951. Óleo sobre tela, $65.00 \mathrm{~cm}$ x 81.00 cm. Coleção do Museu de Arte Contemporânea de São Paulo. Foto: Romulo Fialdini.

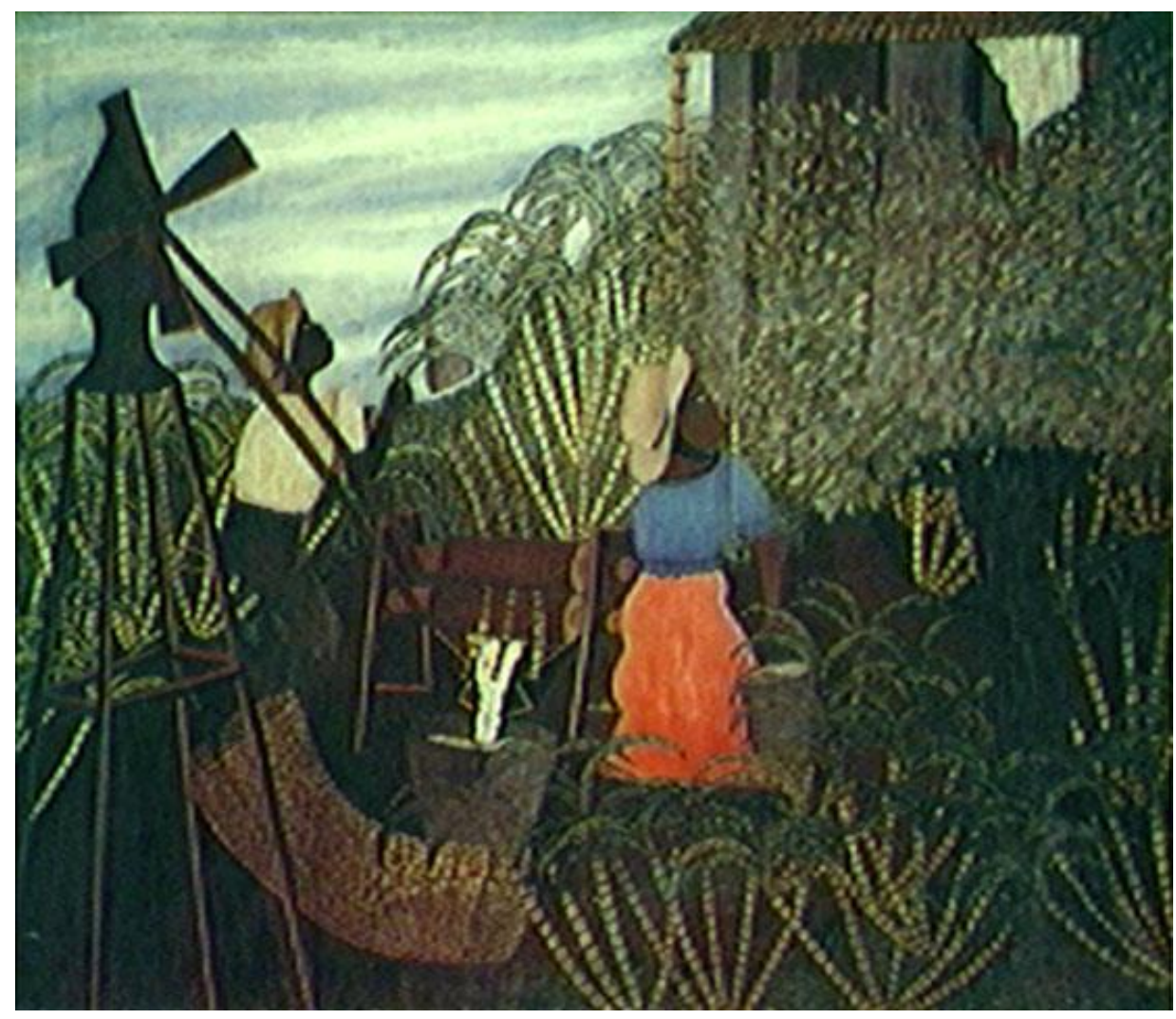

Fonte: MOENDA. In: ENCICLOPÉDIA Itaú Cultural de Arte e Cultura Brasileiras. São Paulo: Itaú Cultural, 2018. Disponível em: <http://enciclopedia.itaucultural.org.br/obra9252/moenda>. Acesso em: $10 \mathrm{de}$ Jun. 2018.

Antes de prosseguir, faz-se necessário definir o que se entende, neste estudo, por arte primitiva. Segundo Oscar D’Ambrósio, embora a discussão seja longa, convencionou-se chamar primitivos aqueles artistas não-eruditos, cuja arte nasce de temas populares, quase sempre de inspiração rural. Contudo, quando se tem a temática urbana, costuma-se utilizar o termo naïf ("ingênuo, do francês), designando sobretudo os artistas que rejeitam as regras ou que não tiveram acesso a elas. Para o autor, cores vivas, composições imaginativas, estilização e poder de síntese são algumas das 
características presentes nessa tendência, sendo vertidas para a tela com soluções técnicas aparentemente rudimentares ${ }^{263}$.

Os artistas primitivos, ou primitivstas, conforme os denomina Mário Tavares Chicó, estão situados numa posição estética que está à margem da arte erudita, tradicional ou inovadora. "Esta é encarada por eles com alguma dose de ingenuidade, não apenas imitativa (caso comum nos amadores) - mas capaz de revelar, por frescura de imaginação, novas possibilidades expressivas, influenciando assim a arte contemporânea" ${ }^{264}$. Esses artistas são quase sempre autodidatas, pois desenvolvem seu trabalho sem a influência proveniente de uma escola de Belas Artes. Começando a pintar praticamente por impulso, esses artistas encontram seus próprios meios para resolver as dificuldades técnicas que vão encontrando ${ }^{265}$.

Voltando aos três artistas primitivos que integraram a representação brasileira da IX, salvo José Antônio da Silva, que marcava presença nas bienais desde a primeira edição (1951, 1953, 1955, 1961, 1963, 1965 e 1967), Chico da Silva e Waldomiro de Deus Souza talvez não tivessem tido a oportunidade de estar numa bienal, se não fosse pelo incidente relatado acima. Isso porque ambos integraram a edição de 1967 e, depois, só voltariam à bienal em 1978 e 1995, respectivamente.

José Antônio da Silva, artista e trabalhador rural, chamou a atenção dos críticos Lorival Gomes Machado e Paulo Mendes de Almeida, bem como do filósofo João Cruz e Costa, quando participou da exposição inaugural da Casa da Cultura de Ribeirão Preto, em 1946. Em 1948, após realizar uma mostra individual na Galeria Domus, na cidade de São Paulo, o artista teve uma tela comprada por Pietro Maria Bardi, então diretor do MASP, e incorporada ao acervo do museu. Anos mais tarde, na I Bienal, em 1951, o artista recebeu o prêmio de aquisição do Museum of Modern Art (MoMA) ${ }^{266}$. As trajetórias de José Antônio da Silva e de Heitor dos Prazeres, tão próximas das bienais,

${ }^{263}$ D'AMBROSIO, Oscar. Os pincéis de Deus: vida e obra de do pintor naïf Waldomiro de Deus. São Paulo: Editora UNESP, 1999. Cf. também D'AMBROSIO, Oscar Alejandro Fabian. Um mergulho no Brasil Naif: a Bienal Naifs do Brasil do SESC Piracicaba: 1992 a 2010. 2013. 204 f. Tese (Doutorado em Educação, Arte e História) - Universidade Presbiteriana Mackenzie, São Paulo, 2013.

${ }^{264}$ CHICÓ, Mário Tavares. Arte naïf. In Dicionário de pintura universal. Lisboa: Editorial Estúdios Cor, 1973, p. 6.

${ }^{265}$ ANDRADE, G. E. e ARDIES, J. A arte naïf no Brasil. São Paulo: Empresa das Artes, 1998.

${ }^{266}$ JOSÉ Antônio da Silva. In: ENCICLOPÉDIA Itaú Cultural de Arte e Cultura Brasileiras. São Paulo: Itaú Cultural, 2018. Disponível em: <http://enciclopedia.itaucultural.org.br/pessoa2079/jose-antonio-dasilva>. Acesso em: 26 de Jun. 2018. O artista participou dessa bienal com as telas Bi-Campeão (1967, 100 x 80) e Tranquilidade (1967, 180 x 80. Cf. FUNDAÇÃO BIENAL. IX Bienal. (catálogo de exposição) São Paulo: Fundação Bienal, 1967, p. 117. 
colocam em evidência o fato de que a bienal sempre teve atenção para com a tendência primitiva $^{267}$.

Já, Chico da Silva, pintor cearense, após participar da IX Bienal com 5 obras $^{268}$, só voltaria ao evento no fim da década de 1970. O arista começou a desenhar com giz e carvão sobre muros e paredes de casas simples de pescadores no fim dos anos de 1930. Na década seguinte, a partir do incentivo do crítico e pintor suíço Jean Pierre Chabloz, o artista dá início ao uso da pintura à guache, expondo na Galeria Askanasy, no Rio de Janeiro, em 1945, juntamente com Chabloz, Antônio Bandeira e Inimá de Paula. Mais tarde, entre 1961 e 1963, Chico da Silva trabalhou no recém-criado Museu de Arte da UFCE $^{269}$. No ano de 1966, o artista recebeu uma Menção Honrosa na XXXIII Bienal de Veneza.

Entre os três artistas primitivos, foi com Waldomiro de Deus que Mario Schenberg teve mais proximidade. O artista, de origem humilde, teve uma vida itinerante pelo sertão baiano e o norte de Minas Gerais, até 1959, quando veio para a cidade de São Paulo, em que trabalhou como engraxate, ainda adolescente. Sua ligação com a arte data de 1961, quando começou a pintar, na ocasião em que encontrou guache e cartolina na casa em que trabalhou como jardineiro. Pouco depois, foi demitido, por conta do descontentamento de seu patrão, que não estava satisfeito com o trabalho do artista, que passava as noites pintando. No ano seguinte, recebeu o apoio do decorador Terry Della Stuffa, que ofereceu a Waldomiro de Deus material e um local para que pudesse pintar. Foi nesse momento que o pintor conheceu Mario Schenberg, que passou a apoiar seu trabalho e comprou várias de suas telas ${ }^{270}$. Sua primeira exposição individual foi em 1966, na FAAP e, no ano seguinte, foi aceito na IX Bienal. Depois disso, Waldomiro de Deus teve uma carreira bem sucedida, passando a viver de sua arte. Note-se, contudo, que o pintor participou apenas da bienal de 1967, só voltando a participar da mostra em 1995. Waldomiro de Deus pode ser considerado um dos maiores

\footnotetext{
${ }^{267}$ MAGALHÃES, Fábio. Entrevista concedida a Ana Paula Cattai Pismel. São Paulo, 05 abr. 2018. 12 arquivos .MOV (1h52'22'’). [A entrevista encontra-se depositada no Centro Mario Schenberg de Documentação da Pesquisa em Arte - ECA/USP].

${ }^{268}$ FUNDAÇÃO BIENAL DE SÃO PAULO. IX Bienal. (catálogo de exposição) São Paulo: Fundação Bienal, 1967.

${ }^{269}$ CHICO da Silva. In: ENCICLOPÉDIA Itaú Cultural de Arte e Cultura Brasileiras. São Paulo: Itaú Cultural, 2018. Disponível em: <http://enciclopedia.itaucultural.org.br/pessoa9894/chico-da-silva>. Acesso em: 26 de Jun. 2018.

${ }^{270}$ OLIVEIRA, Alecsandra Matias de. Waldomiro de Deus por Mario Schenberg. Pesquisa em Debate, edição 7, v. 4, n. 2, Jul/dez de 2007. ISSN 1808-978X.
} 
primitivos brasileiros, juntamente com Heitor dos Prazeres, José Antônio da Silva e Djanira $^{271}$.

Apesar de ter se tornado conhecido pelas obras com astronaves, o pintor autodidata apresentou, na IX Bienal, telas com temas militares ${ }^{272}$. Para Schenberg, Waldomiro de Deus foi certamente a maior revelação da pintura primitivista brasileira de então. Uma das considerações feitas pelo crítico $^{273}$ a respeito da obra ao artista aponta para um elemento que o diferencia de outros primitivos:

[Waldomiro de Deus] revelou também uma personalidade artística de tipo invulgar entre os primitivistas brasileiros, que promete um grande desenvolvimento futuro. (...) Os pintores primitivistas brasileiros de origem rural, em geral, se caracterizam por uma visão defasada de vários séculos em relação à civilização contemporânea. Frequentemente aparecem artistas da era romântica ou do gótico. Waldomiro surpreendeu pela sua modernidade.

Além das cenas de sua infância no interior da Bahia, o artista trabalhava também com aspectos da vida na metrópole paulistana e com a religiosidade, embora de um modo muito próprio e muitas vezes escatológico. No período em que expôs na bienal de 1967, Waldomiro de Deus era conhecido como o pintor de foguetes, por conta dos trabalhos em que figuraram elementos populares do imaginário da corrida espacial $^{274}$.

No caso desses três artistas, não foram encontradas imagens das obras com as quais participaram da IX Bienal, mas as obras adiante pertencem ao mesmo período e representam uma amostra aproximada do trabalho desses artistas naquele contexto (Figuras 31 a 34).

\footnotetext{
${ }^{271}$ WALDOMIRO de Deus. In: ENCICLOPÉDIA Itaú Cultural de Arte e Cultura Brasileiras. São Paulo: Itaú Cultural, 2018. Disponível em: <http://enciclopedia.itaucultural.org.br/pessoa8628/waldomiro-dedeus>. Acesso em: 26 de Jun. 2018.

272 SCHENBERG, Mario. Pensando a Arte, São Paulo: Nova Stella, 1988, p. 196. As obras que integraram a bienal de 1967 foram: Soldado Brasileiro Buscando a Paz, de 1957 (140 x 130) e Os Grandes Sabidos, de 1967 (140 x 130). Cf. FUNDAÇÃO BIENAL DE SÃO PAULO. IX Bienal. (catálogo de exposição) São Paulo: Fundação Bienal, 1967, p. 118.

${ }^{273}$ SCHENBERG, Mario. Pensando a Arte, São Paulo: Nova Stella, 1988, p. 43.

${ }^{274}$ SCHENBERG, Mario. Pensando a Arte, São Paulo: Nova Stella, 1988, p. 44. Para uma análise ampliada acerca da visão de Schenberg em relação ao artista, veja-se OLIVEIRA, Alecsandra Matias de. Waldomiro de Deus por Mario Schenberg. Pesquisa em Debate, edição 7, v. 4, n. 2, Jul/dez de 2007. ISSN 1808-978X.
} 
Figura 38 - Waldomiro de Deus, Sem título, 1997. Óleo sobre tela, 46 x $55 \mathrm{~cm}$.

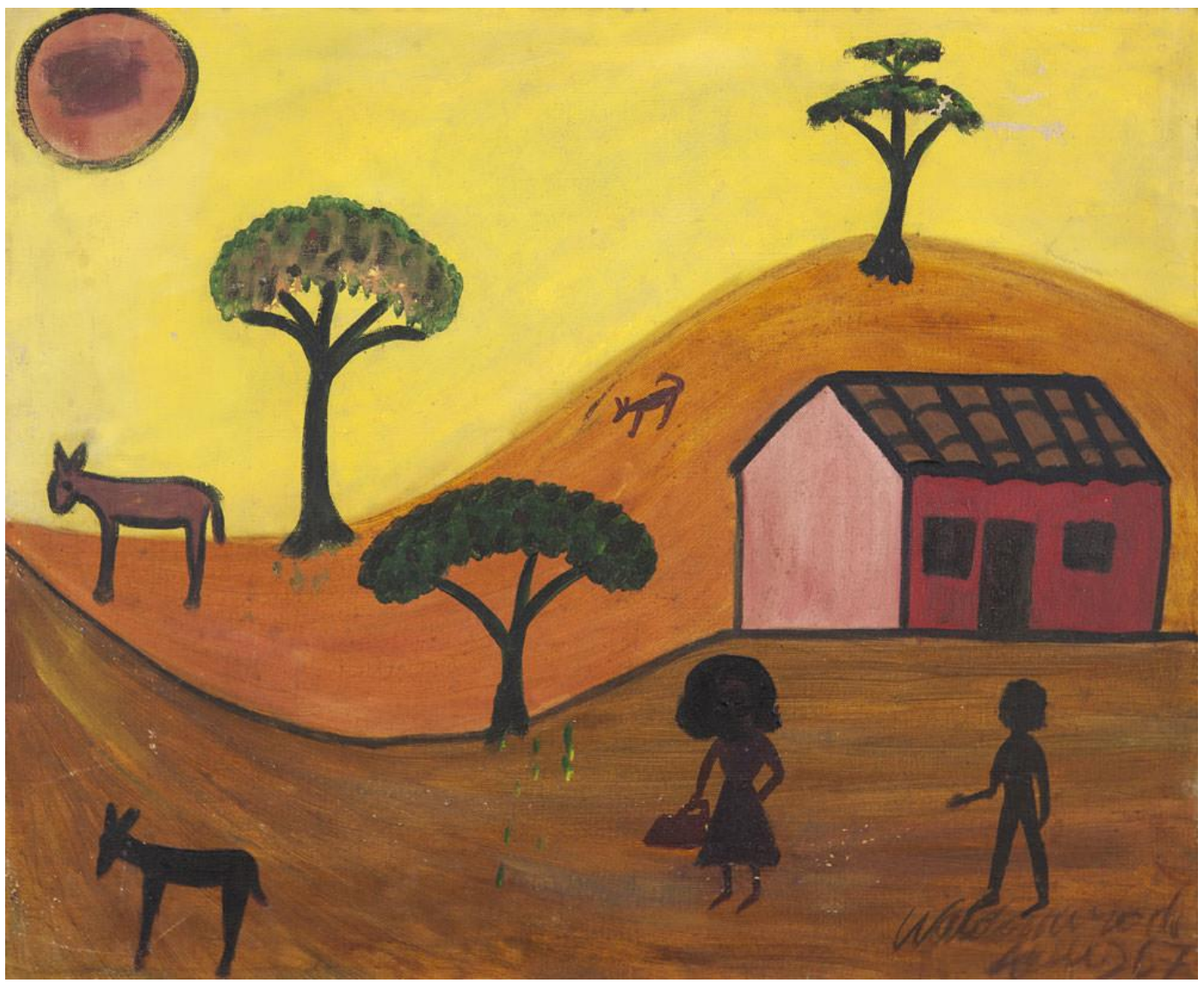

Fonte: ESCRITÓRIO DE ARTE. Disponível em: $\langle$ https://www.escritoriodearte.com/artista/waldomiro-de-deus/sem-titulo-9914> Acesso em: 10 jun. 2018. 
Figura 39 - Waldomiro de Deus, Foguete carioca na lua, 1966. Óleo sobre tela, $193.00 \mathrm{~cm}$ x $98.00 \mathrm{~cm}$. Coleção particular. Foto: Sérgio Guerini.

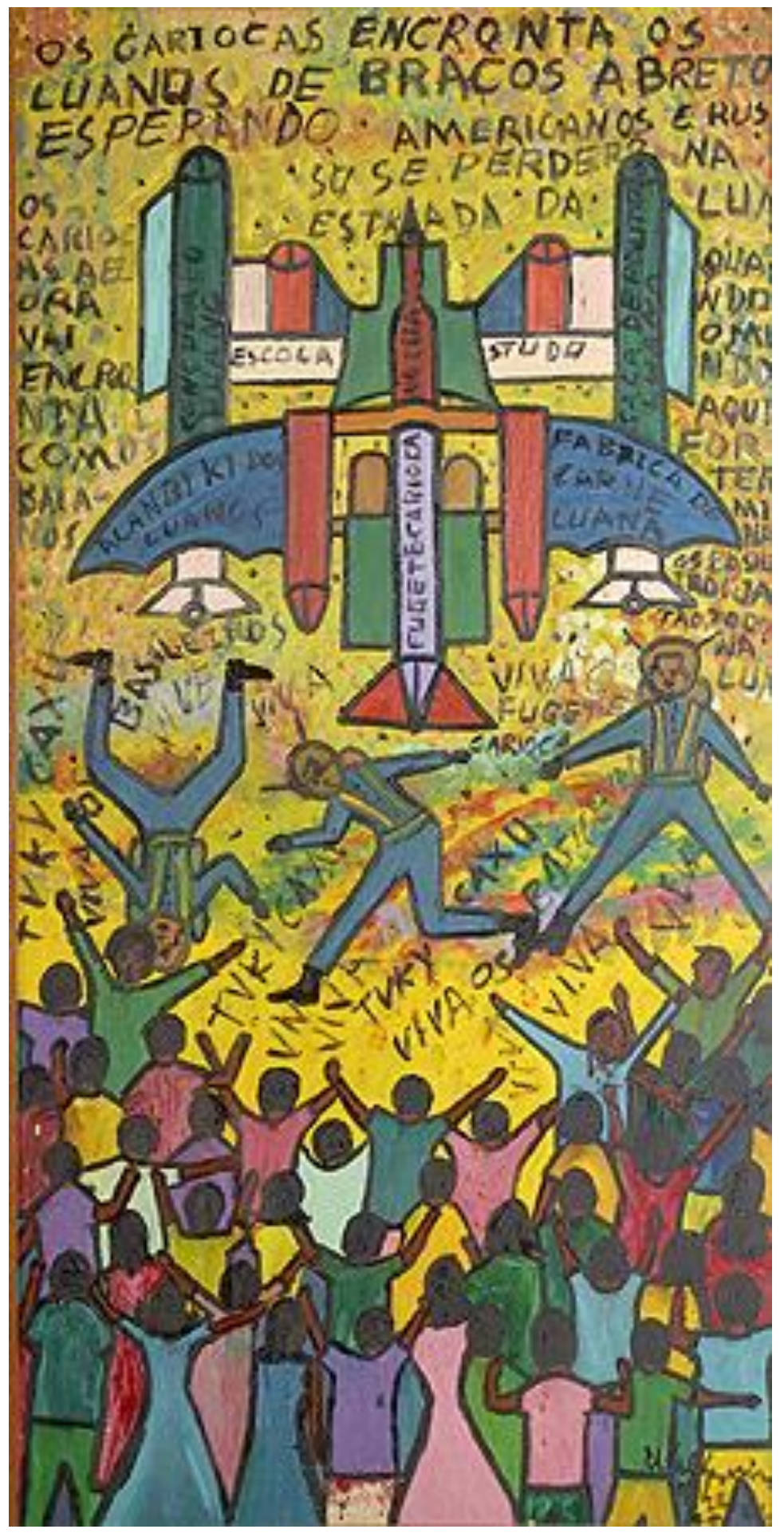

Fonte: FOGUETE Carioca na Lua. In: ENCICLOPÉDIA Itaú Cultural de Arte e Cultura Brasileiras. São Paulo: Itaú Cultural, 2018. Disponível em: <http://enciclopedia.itaucultural.org.br/obra62653/foguetecarioca-na-lua>. Acesso em: 10 de Jun. 2018. 
Figura 40 - Chico as Silva, A luta dos dragões, 1967. Foto: Romulo Fialdini.

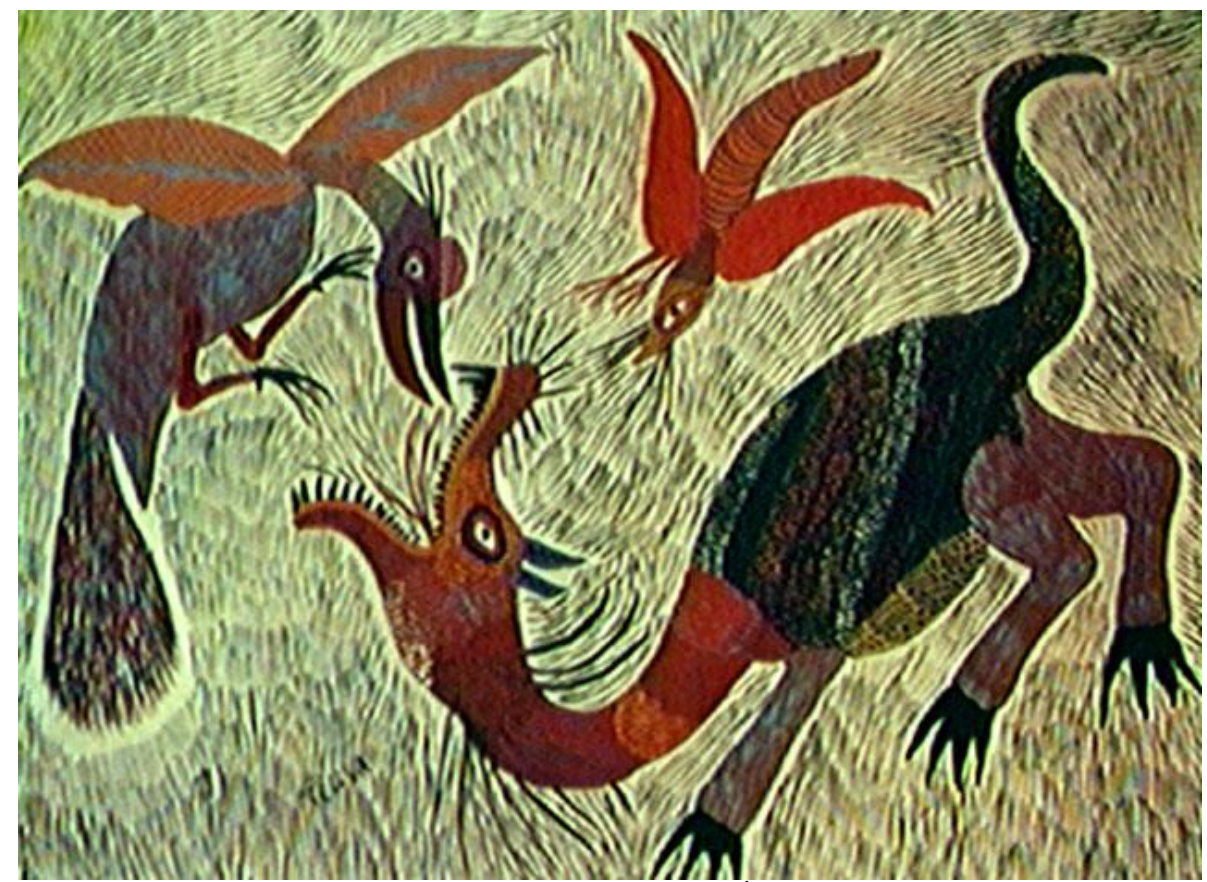

Fonte: A Luta dos Dragões. In: ENCICLOPÉDIA Itaú Cultural de Arte e Cultura Brasileiras. São Paulo: Itaú Cultural, 2018. Disponível em: <http://enciclopedia.itaucultural.org.br/obra11611/a-luta-dos-dragoes >. Acesso em: 10 de Jun. 2018.

Figura 41 - José Antônio da Silva, Ressureição, 1967. Óleo sobre tela, 58.70 $\mathrm{cm}$ x $72.00 \mathrm{~cm}$. Museu de Arte Sacra de São Paulo - MAS. Foto: Romulo Fialdini.

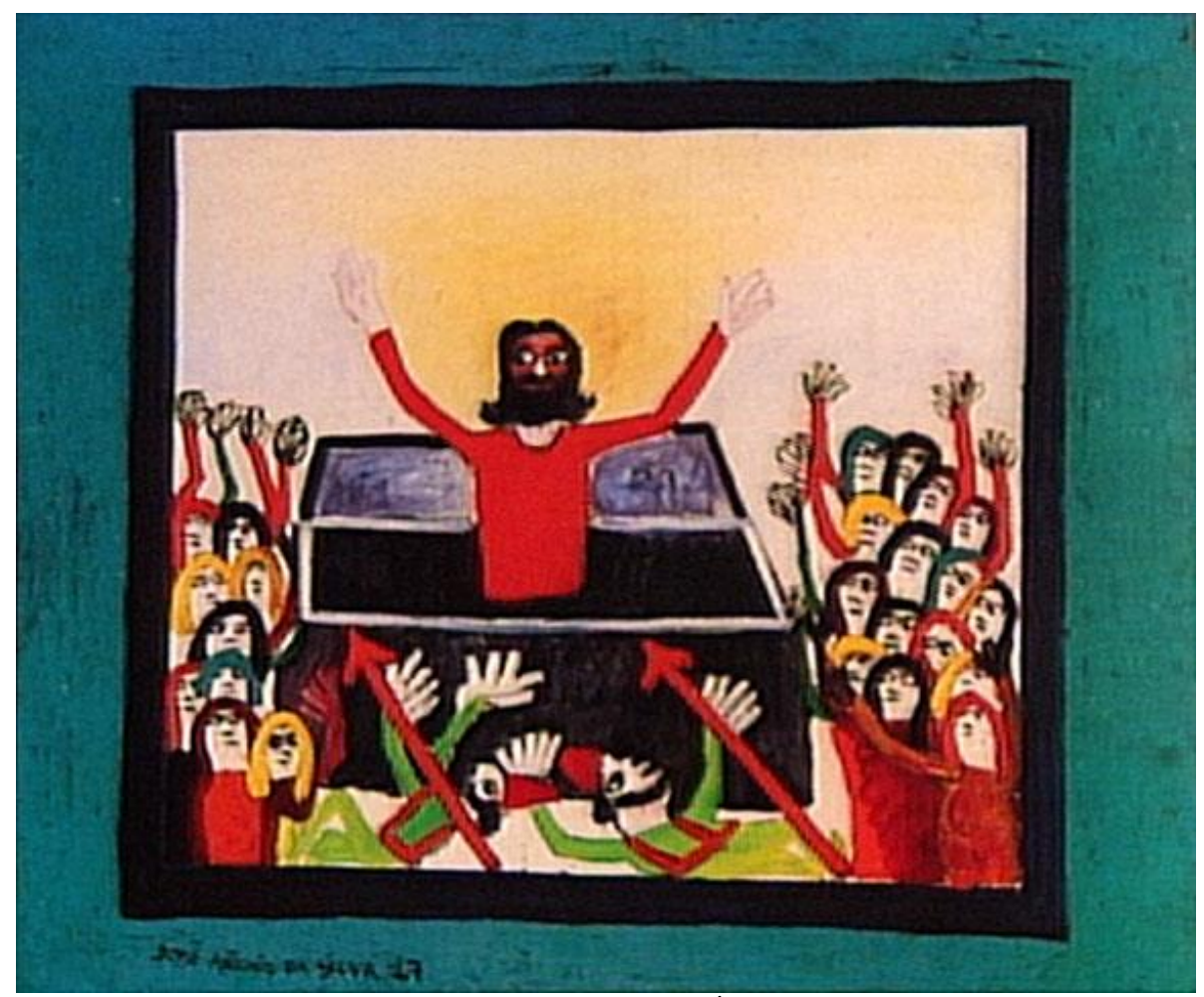

Fonte: RESSURREIÇÃO. In: ENCICLOPÉDIA Itaú Cultural de Arte e Cultura Brasileiras. São Paulo: Itaú Cultural, 2018. Disponível em: $<$ http://enciclopedia.itaucultural.org.br/obra5279/ressurreicao>. Acesso em: 10 de Jun. 2018. 
No fim de 1968, sobreveio o endurecimento da censura por meio do AI-5, que restringiu atividades políticas e manifestações culturais ${ }^{275}$. O professor Mario Schenberg passou então a dedicar mais tempo à crítica de arte, uma vez que fora impedido até mesmo de frequentar bibliotecas e ambientes universitários ${ }^{276}$.

Marcada pelo boicote, ao qual aderiram artistas, críticos de arte e intelectuais, a $\mathrm{X}$ Bienal enfrentou dificuldades que, com maior ou menor êxito, foram contornadas pela Comissão Técnica e pelo Júri de Seleção, que organizou várias salas especiais, além da sala geral da representação brasileira.

A mostra teve lugar entre 27 de setembro e 14 de dezembro de 1969. A comissão técnica de artes plásticas foi integrada por Aracy Amaral, Edyla Mangabeira Unger, Frederico Nasser, Mário Barata, Waldemar Cordeiro e Wolfgang Pfeiffer ${ }^{277}$. Participaram da X Bienal de São Paulo 446 artistas provenientes de 53 países, exibindo 2.572 obras. Diante do movimento internacional de boicote, o número de artistas participantes caiu pela metade se comparado à edição anterior. Esse período de baixa da bienal se agravaria no ano seguinte.

\footnotetext{
${ }^{275}$ Folha registrou trajetória de FHC, da USP à Presidência. Jornal Folha de São Paulo, 18 jun. 2011. Para Motta (2014, p. 148), o "Ato Institucional no 5, editado em 13 de dezembro de 1968, foi sem dúvida um divisor de águas na história do regime militar. Ele representou o ponto culminante de tendências autoritárias em vigor desde o golpe de 1964 e, nesse sentido, correspondeu às demandas dos grupos de direita pelo 'aprofundamento da Revolução'. Para tais segmentos, a 'limpeza' iniciada em 1964 fora interrompida e incompleta, sobretudo nas universidades, e a segurança nacional reclamava novas medidas de força para derrotar os inimigos. De acordo com essa visão, a falta de rigor das punições teria estimulado a reorganização dos grupos de esquerda, que se tornaram mais ousados e contestadores, principalmente ao longo de 1968, quando, nas ruas, lançaram sério desafio ao poder militar. Além disso, os órgãos de informação possuíam evidências sobre o aumento das atividades da esquerda armada, que tinha planos de intensificar ações em breve. Evidentemente, nas avaliações oficiais sobre o perigo subversivo só entravam as ações da esquerda, e não os atos terroristas cometidos por grupos de direita, alguns deles travestidos em organizações revolucionárias para aumentar a sensação de perigo iminente".

276 “Eu não me aposentei, fui aposentado pelo AI-5. Fui aposentado aqui na Universidade do São Paulo. [...] Eu estava com uma carga política muito grande, tinha tido vários processos... É verdade que eu tinha sido absolvido de todos os processos - cinco processos - que eu tive, mas depois disso fui aposentado. Quer dizer, em 1965 fui finalmente absolvido de todos os processos em que eu estava incluído e um outro caducou, mas, em 1969, fui aposentado. Aí, a situação ficou difícil. Era até perigoso eu aparecer lá pela universidade para consultar a biblioteca, porque eles podiam dizer que eu estava exercendo atividades dentro da universidade, e não sei que sanção poderia aplicar. Eu interrompi completamente minhas atividades". SCHENBERG, Mário. Mário Schenberg (depoimento, 1978). Rio de Janeiro, CPDOC, 2010, p. 39-40.

${ }^{277}$ FUNDAÇÃO BIENAL. Bienal a Bienal. Disponível em: $\langle$ http://www.bienal.org.br/FBSP/pt/AHWS/BienalaBienal/Paginas/6BienalSaoPaulo.aspx?selected=6 .
} Acesso em 15 jan. 2013. 
Todo o segmento cultural do país ressentia-se da censura que, não ocorrendo apenas nas bienais, alcançava diversas outras exposições, das quais eram retiradas quaisquer obras consideradas ofensivas ao regime militar. No mesmo ano, ocorreu a invasão e o fechamento da exposição que apresentaria os trabalhos dos artistas que participariam da VI Bienal dos Jovens de Paris (no MAM do Rio de Janeiro), antes mesmo de sua inauguração ${ }^{278}$.

Essa foi a causa imediata do movimento de boicote à X Bienal de São Paulo, catalisando a revolta de artistas, críticos e intelectuais perante a situação incômoda em que se encontrava o país. Some-se a isso o fato de que, também nessa mostra, a retirada de inúmeras obras pela polícia antes mesmo de sua inauguração, não tendo despertado protestos da Fundação Bienal, pôs fim à esperança de que ela se tornasse um polo de resistência ao autoritarismo ${ }^{279}$.

Outro aspecto dessa situação era o fato de a Fundação Bienal ser subvencionada por verbas estaduais e municipais, dependendo do governo para suas atividades. Francisco Alambert \& Polyana Canhête ${ }^{280}$ observam que isso levava a Bienal a ser vista como evento oficial e, portanto, aderida ao status quo do regime militar. Ao se recusarem a participar dela, artistas, críticos de arte e intelectuais endereçavam ao governo instaurado no país sua manifestação de repúdio.

Mário Pedrosa, então presidente da Associação Brasileira de Críticos de Arte (ABCA), foi quem deu início ao movimento pelo boicote, protestando violentamente “contra a censura do Itamaraty às obras selecionadas, em exposição no MAM do Rio, para a VI Bienal de Paris" ${ }^{281}$. No exterior, o crítico Pierre Restany apoiou a bandeira: organizou em 16 de junho de 1969, no Museu de Arte Moderna de Paris, uma reunião na qual artistas e intelectuais elaboraram uma petição de boicote, com cerca de 300 assinaturas, enviada a Ciccillo Matarazzo ${ }^{282}$.

Pierre Restany, aderindo ao boicote, se retirou da organização da sala especial internacional "Arte e tecnologia", tarefa iniciada por ele ainda em 1968. Os trabalhos estavam bastante adiantados quando isso aconteceu. Juntamente com o crítico francês,

\footnotetext{
278 AMARANTE, Leonor. As Bienais de São Paulo: 1951 a 1987. São Paulo: Projeto, 1989.

279 AMARANTE, Leonor. As Bienais de São Paulo: 1951 a 1987. São Paulo: Projeto, 1989, p. 182.

${ }^{280}$ ALAMBERT, Francisco \& CANHÊTE, Polyana. Bienais de São Paulo: da era do museu à era dos curadores. São Paulo: Boitempo, 2004.

${ }^{281}$ Cf. Cronologia. In PEDROSA, Mário. Política das Artes. Otília Beatriz Fiori Arantes (org.). São Paulo: EDUSP, 1995, p. 360.

${ }^{282}$ ALAMBERT, Francisco \& CANHÊTE, Polyana. Bienais de São Paulo: da era do museu à era dos curadores. São Paulo: Boitempo, 2004, p. 124-25.
} 
também se retiraram artistas e instituições tecnológicas que fariam parte dela ${ }^{283}$. Por esse motivo, a sala não foi concretizada.

Países como Estados Unidos, França, México, Suécia e Argentina, bem como vários artistas, isoladamente, aderiram ao boicote logo de início. Ao longo da organização da mostra, houve ainda muitas desistências de última hora, entre elas a da União Soviética. Muitos desses países, inclusive, se retiraram das bienais por várias edições $^{284}$. Algumas delegações de artistas que resolveram se retirar da Bienal já tinham suas obras no Pavilhão Armando Arruda Pereira em fase de montagem. Esse foi um dos problemas que a organização da mostra teve que contornar.

Artistas e intelectuais se dividiam, basicamente, em duas posições: aderir ou não ao boicote, com as implicações decorrentes disso, a saber: dar aval ou protestar contra o sistema político de forças que amparava a Bienal ${ }^{285}$. Nesse contexto, apesar de assumidamente comunista, Mario Schenberg optou por levar adiante sua função de jurado na seleção das obras daquela edição. $\mathrm{O}$ crítico não apenas se posicionou contra o boicote, como organizou a sala Novos Valores, assinando o texto de apresentação no catálogo da mostra ${ }^{286}$.

Mas não se pode dizer que, ao participar da Bienal e levar adiante sua colaboração no Júri de Seleção e organização geral, o crítico estivesse dando seu aval ao estado de coisas. Leonor Amarante destaca que seu posicionamento era diferente: dar continuidade a sua função no Júri de Seleção significava ocupar um espaço que, apesar de todos os problemas e críticas com que tinha de lidar, ainda era o foro mais privilegiado para as Artes Plásticas no país. Com relação a isso, Ciccillo Matarazzo certamente deve ter sido muito grato a Mario Schenberg ${ }^{287}$.

Boicotar a Bienal significaria deixar de defender os interesses dos artistas, bem como seu espaço na mostra internacional. Por isso, o crítico não via sua participação

\footnotetext{
${ }^{283}$ AMARANTE, Leonor. As Bienais de São Paulo: 1951 a 1987. São Paulo: Projeto, 1989.

${ }^{284}$ AMARANTE, Leonor. As Bienais de São Paulo: 1951 a 1987. São Paulo: Projeto, 1989.

${ }^{285}$ FUNDAÇÃO BIENAL DE SÃO PAULO. 50 anos Bienal de São Paulo: 1951-2001. (catálogo de exposição) São Paulo: Fundação, 2001.

286 AMARANTE, Leonor. As Bienais de São Paulo: 1951 a 1987. São Paulo: Projeto, 1989, p. 184. Cf. texto de apresentação da sala especial em SHCNBERG, Mario. Novos Valores. In FUNDAÇÃO BIENAL. X Bienal. (catálogo de exposição) São Paulo: Museu de Arte Moderna de São Paulo, 1969, p. 445.

287 [Informação verbal] MAGALHÃES, Fábio. Entrevista concedida a Ana Paula Cattai Pismel. São Paulo, 5 abr. 2018. 12 arquivos .MOV (1h52'22'"). [A entrevista encontra-se depositada no Centro Mario Schenberg de Documentação da Pesquisa em Arte - ECA/USP].
} 
como adesão aos desmandos do regime totalitário, mas como uma forma de protesto, na medida em que marcava sua posição.

Quando se iniciou esta pesquisa, o livro de Leonor Amarante (As Bienais de São Paulo: 1951 a 1987. São Paulo: Projeto, 1989) era a única fonte que permitia situar a posição de Mario Schenberg naquele contexto histórico. Contudo, com base nas entrevistas realizadas foi possível reunir informações mais completas sobre o posicionamento de Schenberg contra o boicote à bienal. $\mathrm{O}$ curador Fábio Magalhães (2018), que também se posicionou quanto a esse ponto, forneceu dados importantes a respeito do debate que se deu entre aqueles que se retiraram do certame e os que nele permaneceram.

Note-se, antes disso, a abertura característica do posicionamento de Mario Schenberg, para quem não havia lugar para dogmatismo (AGUILAR, 2018) ${ }^{288}$. Algumas das atitudes do crítico reforçam esse ponto, como a liberdade que Schenberg se reservava mesmo quando se tratava das orientações do Partido Comunista, do qual fazia parte. Um exemplo de sua postura pode ser visto quando da primeira prisão do crítico (em 1948) e outros membros do Partido Comunista após sua extinção. A orientação do Comitê Central era a de que seus membros não fornecessem nenhuma informação e se recusassem a assinar toda sorte de documentos enquanto estivessem sob custódia da polícia política. O problema era que, sem assinar a ficha de identificação, os presos não poderiam requerer habeas corpus. Carlos Frydman, que foi preso na mesma cela de Schenberg, relata que, diante desse dilema, o crítico foi o único a ter coragem de abordar a questão, argumentando que era preferível assinar a ficha, caso contrário a polícia poderia fazer com eles o que bem entendesse e ninguém poderia ajudá-los do lado de fora ${ }^{289}$.

Além disso, destaque-se que, caso o crítico fosse ortodoxo em sua visão do comunismo, jamais teria proferido palestras no Projeto Rondon, no fim da década de 1970, tendo em vista que o programa fora criado pelo Regime Militar para fazer frente ao apelo da esquerda, que encontrava receptividade entre os universitários (tratava-se de uma ação de persuasão como via alternativa à repressão) (MOTTA, 2014) $)^{290}$.

\footnotetext{
288 [Informação verbal] AGUILAR, José Roberto. Entrevista concedida a Ana Paula Cattai Pismel. São Paulo, 10 mai. 2018. 1 arquivo .mp3 (21'). [A entrevista encontra-se depositada no Centro Mario Schenberg de Documentação da Pesquisa em Arte - ECA/USP].

${ }^{289}$ Cf. KINHSHITA, Dina Lida. Mario Schenberg: o cientista e o político. Brasília: Fundação Astrogildo Pereira, 2014.

${ }^{290}$ Carta de agradecimento de Sérgio Mário Pasquali, presidente do Projeto Rondon, pelo seminário "Conhecimento Científico e a Sociedade", realizado no Instituto de Física da UFBA, entre 11 e 14 de
} 
Finalmente, há o apoio dado por Schenberg ao artista João Parisi Filho - que na década de 1960 foi acusado de pertencer ao CCC (Comando de Caça aos Comunistas) -, sobre o qual o crítico escreveu no ano de $1969^{291}$. Fábio Magalhães (2018) ${ }^{292}$ afirmou que foi Schenberg quem fez com que ele visitasse uma exposição desse artista, que o crítico considerou muito bom, mesmo com as grandes divergências de visão de mundo que havia entre Parisi Filho e Schenberg. O artista participou da IX e X bienais de São Paulo, em 1967 e 1969²93, além de ter realizado exposições individuais em 1963, 1965 e $1966^{294}$. Nesse período, João Parisi Filho explorava o imaginário dos fora da lei e do submundo da marginalidade, bem como da violência e da cultura de massa, por meio da narrativa própria dos gibis e da propaganda, com vistas ao "esforço mínimo" que exigem do expectador 295 .

Mario Schenberg ${ }^{296}$ passou a ter maior contato pessoal com Parisi Filho quanto este o procurou a fim de que o crítico escrevesse o texto de apresentação para a exposição individual que faria em 1965 na galeria Dearte. Sobre sua relação com o artista, Schenberg ${ }^{297}$ aponta o seguinte:

Apesar das profundas divergências de filosofia e posição política que sempre existiram entre nós, a capacidade criadora de Parisi sempre me convenceu e não pude deixar de reconhecer a sua autêntica

setembro de 1979. Brasília/DF; s/d.; 1d; 1p.; assinado; impr/dat.; original. Carta de agradecimento Sérgio Mário Pasquali, presidente do Projeto Rondon, pelo seminário "Conhecimento Científico e a Sociedade" realizado no Instituto de Física da UFBA, entre 18 e 20 de outubro de 1979. Brasília/DF; s/d.; 1d; 1p.; s/assinatura; impr/dat.; original. O coronel Sérgio Mário Pasquali, ex-secretário geral e ex-titular do Ministério da Educação no Governo do general João Batista Figueiredo, atuou na criação do Projeto Rondon. UNIVERSIDADE FEDERAL DO ACRE. Coronel Sérgio Mário Pasquali. Disponível em: <http://www.ufac.br/site/news/coronel-sergio-mario-pasquali>. Acesso em 10 jun. 2018.

${ }^{291}$ SCHENBERG, Mario. João Parisi Filho. In. AJZENBERG, Elza (org.). Arte e Ciência - Schenberg: Textos Críticos (Diálogos II). São Paulo: ECA/USP, PM Studium Comunicação e Design, 2015. Cf. também MAGALHÃES, Fábio. Entrevista concedida a Ana Paula Cattai Pismel. São Paulo, 5 abr. 2018. 12 arquivos .MOV (1h52'22')'. [A entrevista encontra-se depositada no Centro Mario Schenberg de Documentação da Pesquisa em Arte - ECA/USP].

${ }^{292}$ MAGALHÃES, Fábio. Entrevista concedida a Ana Paula Cattai Pismel. São Paulo, 5 abr. 2018.12 arquivos .MOV (1h52'22''). [A entrevista encontra-se depositada no Centro Mario Schenberg de Documentação da Pesquisa em Arte - ECA/USP].

${ }^{293}$ FUNDAÇÃO BIENAL DE SÃO PAULO. IX Bienal. (catálogo de exposição) São Paulo: Fundação Bienal, 1967; FUNDAÇÃO BIENAL DE SÃO PAULO. X Bienal. (catálogo de exposição) São Paulo: Fundação Bienal, 1969.

${ }^{294}$ DICIONÁRIO DE ARTISTAS DO BRASIL. Verbete João Parisi Filho. Disponível em:

<http://www.brasilartesenciclopedias.com.br/nacional/parisi filho_joao.htm〉. Acesso em: 15 jun. 2018. ${ }^{295}$ LEITE, José Roberto Teixeira. Dicionário crítico da pintura no Brasil. Rio de Janeiro: Artlivre, 1988.

${ }^{296}$ SCHENBERG, Mario. João Parisi Filho. In. AJZENBERG, Elza (org.). Arte e Ciência - Schenberg: Textos Críticos (Diálogos II). São Paulo: ECA/USP, PM Studium Comunicação e Design, 2015.

${ }^{297}$ SCHENBERG, Mario. João Parisi Filho. In. AJZENBERG, Elza (org.). Arte e Ciência - Schenberg: Textos Críticos (Diálogos II). São Paulo: ECA/USP, PM Studium Comunicação e Design, 2015, p. 52. 
generosidade básica. A sua filosofia da violência e os seus pendores direitistas exprimiam uma revolta contra a mediocridade da sociedade de consumo e da atividade burguesa atual, que me pareciam uma solução falsa para problemas verdadeiros.

Sobre os trabalhos do artista expostos na IX Bienal, Schenberg destaca que o artista soube combinar, "com muita felicidade, tendências pop com elementos de crítica psicológica, revelando notável humor" 298 .

${ }^{298}$ SCHENBERG, Mario. João Parisi Filho. In. AJZENBERG, Elza (org.). Arte e Ciência - Schenberg: Textos Críticos (Diálogos II). São Paulo: ECA/USP, PM Studium Comunicação e Design, 2015, p. 53. 
Figura 42 - A noite dos gângsters, 1967, de João Parisi Filho.

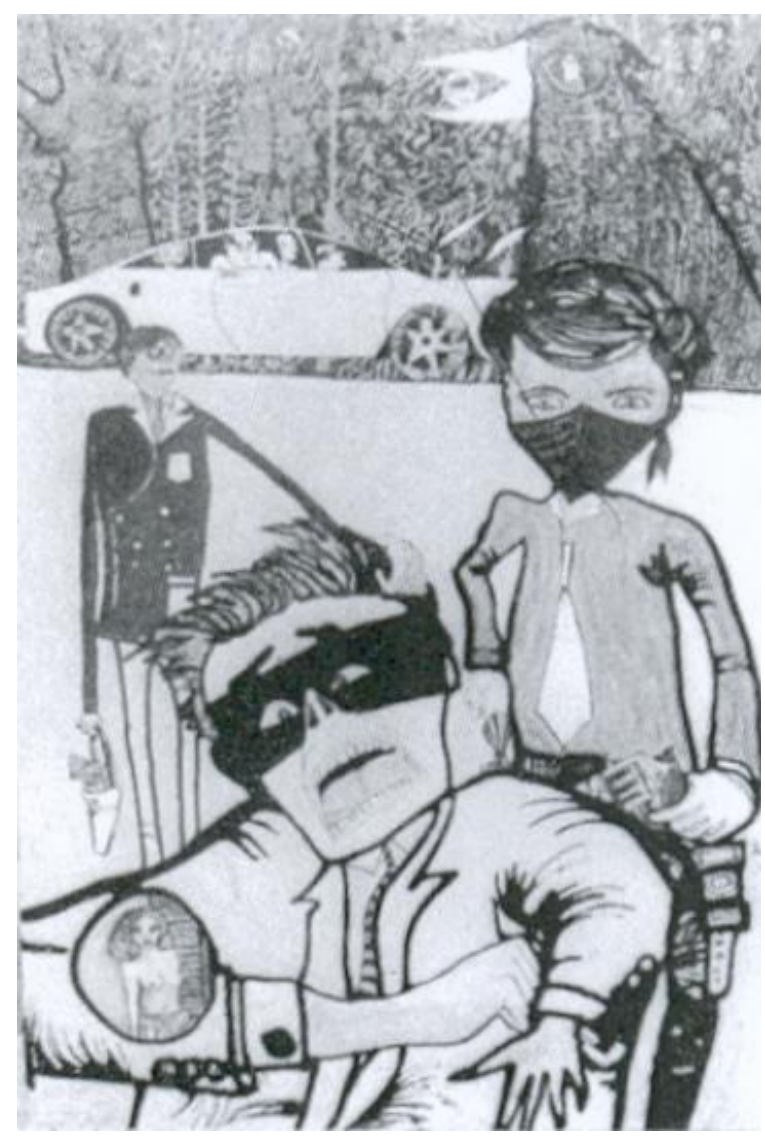

Fonte: PONTUAL, Roberto. Dicionário Brasileiro de Artes Plásticas. Rio de Janeiro: Ed. Civilização Brasileira, 1969. p.406. 
Diante desses fatos, não é difícil compreender que Mario Schenberg não se sentisse obrigado a aceitar a orientação da AICA aos críticos que faziam parte dos quadros da associação. Afinal, para ele, às vezes, era preciso enfrentar situações duras para fazer valer convicções, visão de mundo e de justiça, caso contrário perde-se um espaço que, depois, será difícil de reconquistar ${ }^{299}$. Essa premissa, refletida em seu posicionamento em relação ao boicote da Bienal no fim da década de 1960, está intimamente relacionada com uma frase que o crítico teria proferido numa reunião da base do Partido Comunista, em 1956, em contexto semelhante: "Escuta, disputamos em liberdade. Mas política, você precisa lembrar, [...] é uma atividade dura em que, muitas vezes, se deve enfrentar situações internas conflitantes e violentas mesmo não estando de acordo com elas." ${ }^{300} \mathrm{O}$ crítico queria dizer que, apesar dos atritos e diferenças de entendimento internos ao partido, era importante persistir buscando o objetivo comum a todos, em lugar de meramente denunciar o que estava errado, sair do partido e ir para casa.

Apesar da firmeza característica do posicionamento do crítico, existe um outro fator a ser levado em consideração. No momento em que foi deflagrado o boicote à Bienal, que levou a baixas importantes, tanto na organização da mostra quanto na quantidade de artistas e obras que integrariam as diversas representações, Mario Schenberg estava sentindo os efeitos do recrudescimento da censura e do AI-5 em outras frentes de sua atuação. Pode-se supor que se o crítico aderisse ao boicote à Bienal estaria renunciando ao único lugar de poder e de liberdade de ação a que ainda tinha acesso, uma vez que já haviam sido negados e ele o acesso aos meios acadêmicos e políticos. Afastado do meio acadêmico no Brasil e sofrendo perseguições de fundo político, o crítico ainda encontrava voz e visibilidade no meio da arte.

Fara fazer frente ao movimento pelo boicote à bienal, Mario Schenberg utilizava o exemplo do que havia ocorrido em Portugal no período salazarista, em que o boicote realizado pelos intelectuais havia comprometido a abertura democrática. Sobre esse aspecto, relata Fábio Magalhães (2018):

\footnotetext{
${ }^{299}$ KINHSHITA, Dina Lida. Mario Schenberg: o cientista e o político. Brasília: Fundação Astrogildo Pereira, 2014.

${ }^{300}$ KINHSHITA, Dina Lida. Mario Schenberg: o cientista e o político. Brasília: Fundação Astrogildo Pereira, 2014, p. 278. Segundo a autora, Luiz Hildebrando relembrou frase de Mario Schenberg em reunião da cisão da base do PCB na USP, em 1956.
} 
[...] o Mario tinha uma outra visão, uma visão voltada à leitura das experiências em Portugal, onde esse boicote foi desastroso. O Mario chamava atenção disso. Na época em que houve uma evasão, em que foi para o exílio uma grande parte da intelectualidade portuguesa. Havia um grande boicote, durante o período salazarista, das atividades culturais e isso não trouxe nenhum benefício à abertura democrática em Portugal. Pelo contrário, houve um rebaixamento da produção artística graças a esse isolamento, provocado pelos próprios intelectuais portugueses, muitas vezes.

[...] As pessoas que têm o que dizer e que fazem resistência, se elas não ocupam [esse espaço], se elas se retiram, esse espaço vai ser ocupado por alguém, não é? Você diminui o nível do debate cultural, sem dar uma contribuição efetiva a ele. [...] O Schenberg tinha uma visão mais em longo prazo, e o tempo mostrou que ele tinha razão ${ }^{301}$.

Fábio Magalhães (2018) 302 observa, ainda, que Schenberg sempre argumentava que a Bienal não era um aparelho da ditadura, mas uma instituição independente e que poderia de certa forma fazer frente a ela. Para o crítico, havia uma confusão na questão do boicote à Bienal, como se esta fosse parte de um regime do qual ela não fazia parte. É claro que nem todos aqueles que optaram por se abster do evento naquele contexto pensavam desse modo. O próprio entrevistado (MAGALHÃES, 2018), que tinha familiaridade com a Bienal desde o início dos anos de 1960, disse com muita clareza que, para muitos dos intelectuais que ficaram ao lado de Mário Pedrosa, o foco não era atacar a Bienal, mas mostrar solidariedade ao movimento internacional contra a ditadura.

Pode-se argumentar que o fato de Mario Schenberg ter escolhido ficar na Bienal juntamente com os demais críticos e artistas que o fizeram ajudou a manter o evento de pé, minimizando os prejuízos ${ }^{303}$. Afinal, o desfalque foi significativo, mas poderia ter sido ainda maior, o que certamente teria colocado em perigo a continuidade futura do certame. Nesse momento, a Bienal havia se tornado uma mostra que reunia questões não só das esferas artística, estética e cultural, mas também política e social. Destaque-

\footnotetext{
301 "Enfim, o Mario não estava sozinho, estava com o Sérgio Ferro, que tinha uma posição até mais radical na esquerda do que a de Mario Schenberg. O Sérgio Ferro se envolveu com a luta armada, coisa que Mario Schenberg era contrário. Ele foi preso, foi exilado. E, nesse período, eles foram duas figuras muito importantes pra romper uma parte desse boicote. E tiveram êxito também". MAGALHÃES, Fábio. Entrevista concedida a Ana Paula Cattai Pismel. São Paulo, 5 abr. 2018. 12 arquivos .MOV (1h52'22')). [A entrevista encontra-se depositada no Centro Mario Schenberg de Documentação da Pesquisa em Arte - ECA/USP].

${ }^{302}$ MAGALHÃES, Fábio. Entrevista concedida a Ana Paula Cattai Pismel. São Paulo, 5 abr. 2018. 12 arquivos .MOV (1h52'22'). [A entrevista encontra-se depositada no Centro Mario Schenberg de Documentação da Pesquisa em Arte - ECA/USP].

303 [Informação verbal] TORRES, Caciporé. Entrevista concedida a Ana Paula Cattai Pismel. São Paulo, 8 mai. 2018. 1 arquivo .mp3 (16'39'). [A entrevista encontra-se depositada no Centro Mario Schenberg de Documentação da Pesquisa em Arte - ECA/USP].
} 
se o fato de que a edição de 1969 contou com obras de forte conteúdo de resistência, como as do artista José Roberto Aguilar (2018) ${ }^{304}$.

José Roberto Aguilar (2018) ${ }^{305}$ falou sobre esse momento, no qual também optou por permanecer na Bienal. O artista era da opinião de que era preciso manter ocupado esse espaço a fim de não deixá-lo morrer. Por isso, era mais significativo entrar com algum trabalho no evento do que simplesmente deixar de participar. Aguilar apontou que, tanto para ele quanto para Mario Schenberg, continuar na mostra era um ato de resistência mais efetivo do que apenas se abster. Por isso, o artista integrou a sala Novos Valores com a obra Branca e doce América Latina em flor 1969, 1969 (maçarico, 300 $\mathrm{x} 1500 \mathrm{~cm})^{306}$.

Ambos os lados tiveram êxito. A parcela de artistas, críticos de arte e demais intelectuais que aderiram ao boicote à Bienal conseguiram angariar visibilidade internacional em torno da resistência ao estado de coisas vigente no país. Esse debate se deu não apenas em nível internacional, como também nacional, na medida em que o grupo do qual Schenberg fazia parte, aquele que apoiava a Bienal, conseguiu garantir que a mostra tivesse continuidade. Sobre esse ponto, o curador Fábio Magalhães (2018) observa que, embora tivesse aderido ao boicote naquele contexto, havia diálogo contínuo entre ele, de um lado, e Schenberg, juntamente com Sérgio Ferro, do outro. Não houve rompimento, mas debate ${ }^{307}$.

Com relação à formação do Júri de Seleção da X Bienal, é preciso dizer que não foi isenta de polêmicas. A Associação Brasileira de Críticos de Arte e a Associação Internacional de Artistas Plásticos (sessão nacional) reivindicavam representação nesse Júri, bem como na Assessoria Técnica e nas comissões que realizariam a organização da mostra. Em janeiro de 1969, as duas associações recusam o convite da Fundação Bienal, pois entendiam que não fazia sentido "terem representantes no certame a se

\footnotetext{
${ }^{304}$ MAGALHÃES, Fábio. Entrevista concedida a Ana Paula Cattai Pismel. São Paulo, 5 abr. 2018. 12 arquivos .MOV (1h52'22'). [A entrevista encontra-se depositada no Centro Mario Schenberg de Documentação da Pesquisa em Arte - ECA/USP].

${ }^{305}$ AGUILAR, José Roberto. Entrevista concedida a Ana Paula Cattai Pismel. São Paulo, 10 mai. 2018. 1 arquivo .mp3 (21'). [A entrevista encontra-se depositada no Centro Mario Schenberg de Documentação da Pesquisa em Arte - ECA/USP].

${ }^{306}$ FUNDAÇÃO BIENAL DE SÃ̃O PAULO. X Bienal. (catálogo de exposição) São Paulo: Fundação Bienal, 1969, p. 65.

307 [Informação verbal] MAGALHÃES, Fábio. Entrevista concedida a Ana Paula Cattai Pismel. São Paulo, 5 abr. 2018. 12 arquivos .MOV (1h52'22'"). [A entrevista encontra-se depositada no Centro Mario Schenberg de Documentação da Pesquisa em Arte - ECA/USP].
} 
realizar em setembro próximo sujeitos a acatarem as decisões da Fundação Bienal, que terá sempre maioria de membros e, portanto, de votos"308.

Além disso, as decisões da Assessoria Técnica teriam de passar pela aprovação da Diretoria da Bienal, que não era formada por pessoas conhecedoras de arte. Essa era, aliás, uma crítica à organização das bienais que vinha desde a extinção da função de Diretor Geral, a partir da VII Bienal. Assim, as associações consideravam muito difícil o diálogo com a Bienal. Finalmente, dado o convite tardio e o fato de que todas as decisões já haviam sido tomadas, não era possível "assumir a responsabilidade de uma programação já estabelecida", apoiando-a "como entidades especializadas"309.

Já no que tange ao Júri de Seleção, o convite foi aceito, mas não sem restrições. Em 2 de maio do mesmo ano, a Fundação Bienal convida a AIAP a enviar uma lista com cinco nomes eleitos por seus quadros sociais a fim de escolher dentre as sugestões um representante para integrá-lo ${ }^{310}$. A resposta, contudo, não foi a lista solicitada, mas um único nome, conforme se lê:

[...] nossa entidade, atendendo, solícita, ao pedido da Fundação Bienal, promoveu eleições livres em São Paulo e no Rio para a indicação de um membro do Júri de Seleção, convocando todos os artistas interessados, mesmo aquêles que não pertencem aos seus quadros sociais. Infelizmente não estamos aparelhados para promover eleições em outras cidades brasileiras. $\mathrm{O}$ resultado, portanto, não tem valor nacional. [...] Da nossa consulta, resultou como o mais votado o crítico de arte Mário Schenberg ${ }^{311}$.

Também na Bienal de 1969, Mario Schenberg integrou o Júri com o apoio dos artistas, mesmo sem haver uma eleição organizada pela Bienal. Maurício Nogueira Lima, então presidente da AIAP, lembra ainda que a associação defendeu, quando da elaboração do regulamento da X Bienal, que a eleição fosse realizada diretamente por essa instituição. Isso foi feito, segundo o artista, por meio de um representante na assessoria, o que sugere que, após a recusa inicial, a AIAP aceitou a representação nessa comissão, possivelmente após negociação a respeito dos pontos levantados.

\footnotetext{
${ }^{308}$ AIAP e ABCA recusam convite da Bienal. Folha de São Paulo, $1^{\circ}$ fev. 1969.

${ }^{309}$ Resposta oficial enviada a Francisco Matarazzo Sobrinho por Quirino Campofiorito ( $1^{\circ}$ VicePresidente da AICA) e Mirian Quiaverini (Presidente da AIAP), correspondência datada de 31 de janeiro de 1969. Arquivo Histórico Wanda Svevo, Fundação Bienal.

${ }^{310}$ Carta de Francisco Matarazzo Sobrinho a Maurício Nogueira Lima (Presidente da AIAP), datada de 2 de maio de 1969. Arquivo Histórico Wanda Svevo, Fundação Bienal.

${ }^{311}$ Carta de Maurício Nogueira Lima (Presidente da AIAP) a Francisco Matarazzo Sobrinho, datada de 16 de maio de 1969, p. 1 (foi mantida a grafia original). Arquivo Histórico Wanda Svevo, Fundação Bienal.
} 
Integraram o Júri de Seleção os seguintes nomes: Mark Bercowitz (indicado pela ABCA), Mario Schenberg (pela AICA), Edyla Mangabeira Unger, Oswaldo de Andrade Filho e Walmir Ayala (pela Fundação Bienal). Segundo o regulamento da X Bienal, caberia ao Júri convidar 25 artistas e, entre os previamente inscritos, selecionar outros 25. No que diz respeito às salas especiais, os membros entendiam que os artistas não seriam escolhidos entre os convidados regulamentares ${ }^{312}$.

Analisando as atas das reuniões do Júri de Seleção disponíveis no Arquivo Histórico Wanda Svevo, é possível ver que Mario Schenberg foi muito participativo nas discussões e manteve-se sempre a favor dos artistas, na medida em que discordava de qualquer sugestão para diminuir o número da representação brasileira.

Como exemplo, pode-se destacar que, diante da recusa de muitos dos artistas convidados (entre eles Lygia Clark, Hélio Oiticica, Rubens Gerchmam, Burle Marx, Carlos Vergara), mesmo após terem sido convidados os cinco suplentes, o crítico sugeriu que as vagas fossem redirecionadas para os artistas inscritos, com o que concordaram os demais membros do Júri ${ }^{313}$.

Mario Schenberg defendeu, ainda, a organização das salas especiais previstas, a saber: "Etapas”, "Novos Valores”, “Arte Mágica, Fantástica e Surrealista”, das quais apenas as duas últimas constam no catálogo da mostra. Foi cogitada também a organização de uma sala especial dedicada aos movimentos concreto e neoconcreto, que não chegou a ser realizada. No entender do crítico, era importante ter as salas especiais, a fim de garantir o alto nível da representação brasileira, uma vez que muitos convidados haviam se recusado a participar da X Bienal.

No que diz respeito à sala "Arte Mágica, Fantástica e Surrealista”, Mario Schenberg sugere que o número de artistas seja elevado e observa que seria interessante, antes de escolher os artistas, "considerar dois grupos para a sala: o dos artistas mais antigos, e o dos novos", pois “[h]á artistas de valor indubitável, mas que não estão apresentando novidades. Atingiram seu maior desenvolvimento no passado e ficaram cristalizados" $" 314$.

\footnotetext{
${ }^{312}$ Nota divulgada à imprensa pela Fundação Bienal, em 28 de maio de 1969, intitulada: "Júri da X Bienal convida vinte e cinco artistas". Arquivo Histórico Wanda Svevo, Fundação Bienal. Cf. também FUNDAÇÃO BIENAL. X Bienal. (catálogo de exposição) São Paulo: Fundação Bienal, 1969. Regulamento: Capítulo II, V, $a$, p. 449.

${ }^{313}$ Ata do Júri de Seleção, dia 26 jun. 1969, p. 1. Arquivo Histórico Wanda Svevo, Fundação Bienal.

${ }^{314}$ Ata do Júri de Seleção, dia 7 jul. 1969, p. 1. Arquivo Histórico Wanda Svevo, Fundação Bienal.
} 
Em entrevista à revista Trans/Form/Ação, concedida na década de 1980, o Professor Schenberg comenta que o Júri chegou a descer ao porão da Fundação Bienal para ver se havia ali alguma obra para essa sala, já que não havia muitos trabalhos em vista. Na ocasião, Mario Schenberg recorda que foram apontadas algumas obras (abandonadas pelo artista na Bienal), que o impressionaram muito quando foram enviadas para edições anteriores da mostra ${ }^{315}$.

No decorrer das reuniões do Júri de Seleção foram feitas sugestões no sentido de selecionar, entre os artistas inscritos espontaneamente, os integrantes das salas especiais. Edyla Mangabeira Unger e Marc Bercowitz eram da opinião de que se os inscritos não fossem escolhidos para as salas especiais, não haveria artistas suficientes. Para Walmir Ayala, uma representação com 30 artistas poderia ser tão boa quanto uma com $50^{316}$.

José Humberto Affonseca, que acompanhava Francisco Matarazzo Sobrinho numa intervenção pontual a fim de esclarecer o Júri sobre a possibilidade de mudar o regulamento, sugeriu que fosse feita uma seleção entre os inscritos sem publicidade. Nesse caso, seria apenas publicada uma lista com o nome dos artistas ao fim da seleção ${ }^{317}$.

Mario Schenberg se opôs terminantemente a qualquer mudança do regulamento no meio dos trabalhos, bem como à escolha de artistas inscritos para as salas especiais, chegando mesmo a declarar que, caso o regulamento não fosse cumprido, se retiraria do $J_{u ́ r i}{ }^{318}$. Em seu entender, isso significaria uma mudança de posição que prejudicaria os artistas, na medida em que permitiria diminuir ainda mais uma representação que, nessa edição, já seria bem reduzida em relação às anteriores.

Na X Bienal de São Paulo, Mario Schenberg organizou uma retrospectiva de Ismael Nery com 50 desenhos. Além disso, foi responsável pela sala especial "Novos Valores", da qual participaram 28 artistas jovens de diversas técnicas e tendências como, por exemplo, Gilberto Salvador, Antônio Peticov, Cláudio Tozzi, Carmela Gross, José Roberto Aguilar, Yutaka Toyota, Marcelo Nitsche, João Câmara e Ione Saldanha ${ }^{319}$. Para realizá-la, o crítico enfrentou resistência dos outros membros do Júri de Seleção,

315 SCHENBERG, Mario. Entrevista com Mário Schenberg. (Publicado originalmente na Revista Trans/Form/Ação, v. 3, p. 6-62, 1980). In Trans/Form/Ação. Marília, v. 34, 2011. Edição Especial, p. 154. O crítico diz não se recordar do nome do artista, motivo pelo qual não foi possível saber se os trabalhos mencionados foram expostos ou não.

316 Ata do Júri de Seleção, dia 7 jul. 1969, p. 1. Arquivo Histórico Wanda Svevo, Fundação Bienal.

${ }^{317}$ Ata do Júri de Seleção, dia 7 jul. 1969, p. 2. Arquivo Histórico Wanda Svevo, Fundação Bienal.

${ }^{318}$ Ata do Júri de Seleção, dia 7 jul. 1969, p. 2. Arquivo Histórico Wanda Svevo, Fundação Bienal.

319 AMARANTE, Leonor. As Bienais de São Paulo: 1951 a 1987. São Paulo: Projeto, 1989. 
que a julgavam redundante, já que o propósito da Bienal era apresentar o que havia de mais recente ${ }^{320}$.

$\mathrm{Na}$ apresentação que escreveu para a sala "Novos Valores", Mario Schenberg chamou a atenção para o fato de haver entre os artistas selecionados e os convidados muitos jovens que se encaixariam na proposta daquela sala. Vários deles, apesar da pouca idade, já teriam se tornado personalidades significativas no meio artístico brasileiro $^{321}$. Havia, contudo, muitos outros artistas que pareceram dignos de serem apresentados, mesmo que suas propostas não tivessem ainda uma realização tão definida quanto seus colegas mencionados, o que motivou a organização dessa sala especial ${ }^{322}$.

Para Mario Schenberg, os artistas jovens eram sensíveis aos novos valores que estavam emergindo não apenas de causas de natureza geral (questões demográficas, sociais, políticas e culturais), mas também transformações específicas das artes plásticas, a saber, o declínio do abstracionismo informal, a emergência da arte objetista, da Pop Art e de tendências neodadaístas, assim como a utilização cada vez maior de novos recursos tecnológicos, como a eletrônica, e de novos materiais ${ }^{323}$.

Esses novos caminhos teriam diminuído a importância da longa formação artesanal requerida pelos gêneros tradicionais das artes plásticas, ao mesmo tempo que abriram um vasto repertório de possibilidades para as novas formas de expressão artística. Se muitos artistas experientes estavam indo em direção a essas novas possibilidades, eram os jovens que se sentiam muito mais atraídos por elas, uma vez que frequentemente não conseguiam mais se realizar pelas técnicas tradicionais da pintura $^{324}$.

Ao fim do texto, Mario Schenberg pontua que seria prematuro tecer previsões sobre os rumos dessas novas tendências, embora algumas delas já fossem sentidas internacionalmente, como o declínio do Pop e do Op, o aparecimento de novos tipos de construtivismo e o surto mágico-fantástico. Mas era possível notar, por um lado, o domínio mais seguro das novas técnicas e dos novos materiais em relação à IX Bienal

\footnotetext{
${ }^{320}$ Ata do Júri de Seleção, dia 7 jul. 1969, p. 2. Arquivo Histórico Wanda Svevo, Fundação Bienal. Não foram localizadas as atas das reuniões posteriores a essa data. Por isso, não foi possível reconstituir o desfecho dos debates sobre a sala "Novos Valores".

${ }^{321}$ SCHENBERG, Mario. Novos Valores. In FUNDAÇÃO BIENAL. X Bienal. (catálogo de exposição) São Paulo: Fundação Bienal, 1969, p. 44-5.

${ }^{222}$ SCHENBERG, Mario. Novos Valores. In FUNDAÇÃO BIENAL. X Bienal. (catálogo de exposição) São Paulo: Fundação Bienal, 1969.

${ }^{323}$ SCHENBERG, Mario. Novos Valores. In FUNDAÇÃO BIENAL. X Bienal. (catálogo de exposição) São Paulo: Fundação Bienal, 1969.

${ }^{324}$ SCHENBERG, Mario. Novos Valores. In FUNDAÇÃO BIENAL. X Bienal. (catálogo de exposição) São Paulo: Fundação Bienal, 1969.
} 
e, por outro, a diminuição do ritmo explosivo anterior, indicando, talvez, a busca de novos caminhos da década de $1970^{325}$.

Em relação à X Bienal de São Paulo, o crítico manifestou o mesmo critério da edição anterior em relação à escolha dos artistas para representar a arte brasileira no evento, isto é, privilegiar propostas inovadoras. Os planos para a montagem da exposição, contudo, não foram totalmente viabilizados devido a problemas (já apontados) com a organização do evento. A falta de tempo para que os artistas se inscrevessem e o movimento internacional de contestação à Bienal fizeram com que o número de artistas convidados ficasse abaixo do número estabelecido inicialmente ${ }^{326}$.

Mesmo assim, Schenberg fez algumas considerações interessantes sobre a predominância de artistas jovens que marcou a representação do país (muitos dos quais participaram da Bienal com o apoio do crítico); a diminuição de quadros e esculturas, relacionada com o aumento das pesquisas concernentes à arte objetista; e o desenvolvimento de novas formas de expressão (arte conceitual, sinestésica, além de recursos tecnológicos elétricos, eletrônicos e de novos materiais) ${ }^{327}$.

Como membro do Júri de Seleção da X Bienal, Mario Schenberg participou, ainda, de uma mesa-redonda para a qual foram convidados críticos de arte do Brasil e do exterior, cujo objetivo era discutir aspectos da organização e da premiação das bienais, com vistas a sua reformulação ${ }^{328}$. A contribuição do crítico será vista com detalhes no terceiro capítulo desta tese.

Entre os destaques da X Bienal estava a instalação da artista Mira Schendel ${ }^{329}$, com quem o crítico manteve contato prolongado, tendo escrito diversos textos sobre seu

\footnotetext{
${ }^{325}$ SCHENBERG, Mario. Novos Valores. In FUNDAÇÃO BIENAL. X Bienal. (catálogo de exposição) São Paulo: Fundação Bienal, 1969.

${ }^{326}$ SCHENBERG, Mario. Pensando a Arte, São Paulo: Nova Stella, 1988.

${ }^{327}$ SCHENBERG, Mario. Pensando a Arte. São Paulo: Nova Stella, 1988.

${ }^{328}$ Críticos de Arte vão debater reformulação das bienais. Nota enviada à imprensa, documento não datado. Arquivo Histórico Wanda Svevo, Fundação Bienal.

${ }^{329}$ Myrrha Dagmar Dub, que mais tarde viria a adotar o nome de Mira Schendel, nasceu em Zurique (Suíça) no ano de 1919 e morreu na cidade de São Paulo em 1988. A artista produziu desenho, pintura e escultura. Em sua longa trajetória, dialogou com diversas questões que se colocavam no contexto da arte durante o período de sua produção. Mudando-se para Milão na década de 1930, Mira Schendel estuda arte e filosofia. Contudo, durante a Segunda Guerra Mundial (1939-1945), teve de abandonar seus estudos. Logo após o término da guerra, estabelece-se em Roma em 1946. Já em 1949, obtém permissão para mudar-se para o Brasil. Inicialmente, a artista fixa residência em Porto Alegre (onde se dedicou ao design gráfico, pintura, escultura e outras atividades). Em 1953, a artista suíça passa a morar na cidade de São Paulo, assinando então com o nome pelo qual se tornou conhecida. Sua participação na $1^{\text {a }}$ Bienal Internacional de São Paulo, dois anos antes, tornou possível, por um lado, sua inserção no cenário nacional e, por outro, o contato com as experiências em nível internacional. Cf. ENCICLOPÉDIA ITAÚ CULTURAL DE ARTES VISUAIS. Verbete Mira Schendel. Disponível em: 〈http://enciclopedia.itaucultural.org.br/pessoa2450/mira-schendel〉. Acesso em 16 nov. 2015.
} 
trabalho. Ondas Paradas de Probabilidade (que recebeu menção honrosa) consistia num ambiente com fios de náilon transparentes presos ao teto, entre os quais os visitantes poderiam se movimentar no espaço expositivo.

Artista multifacetada do ponto de vista da expressão formal, mas com unidade conceitual $^{330}$, Mira Schendel, em meio à movimentada década de 1960, operou dentro de seu complexo referencial artístico e filosófico. Tendo nascido na Suíça e vivido na Itália, já estudara artes visuais e filosofia quando desembarcou em terras brasileiras.

Em seu percurso, foi acompanhada de perto por Mario Schenberg, o crítico de arte que, baseando-se em referenciais teóricos compartilhados com a artista, mergulhou em sua obra e escreveu sobre ela diversos textos. Entre suas referências está o pensamento oriental, mais precisamente o chinês. Um exemplo é o texto Monotipias de Mira Schendel ${ }^{331}$, no qual Mario Schenberg utiliza esse referencial que tem em comum com a artista para fazer com que a série, que empresta seu nome ao texto mencionado, ganhe ainda mais vida e se aproxime do público ${ }^{332}$. Schenberg acompanhou os desdobramentos do trabalho de Mira Schendel com bastante atenção entre os anos de 1960 e 1988, quando a artista faleceu.

Sobre o apoio que o crítico deu a Mira Schendel, Fábio Magalhães (2018) relata um episódio muito interessante presenciado por ele. Numa certa ocasião, foi realizado um leilão beneficente em prol da construção do Hospital Albert Einstein, evento que teve lugar no Museu de Arte de São Paulo (na época, localizado na Rua 7 de Abril). Foram leiloadas várias obras doadas por diversos artistas e, apesar de não haver um mercado de arte significativo, os compradores tinham a intenção de colaborar para a construção do hospital. Quando a obra de Mira Schendel foi exibida para receber os lances, ninguém se interessou. Não foi dado um único lance.

Schenberg ficou bastante irritado com o fato: levantou-se da plateia, onde estava sentado, e disse aos presentes que eles não entendiam nada de arte, acrescentando que Mira Schendel era a melhor artista que tinha sido apresentada naquele leilão. $O$ curador explica que, no caso de Mira Schendel, o crítico era mais incisivo, porque a obra dela era rechaçada, "era uma coisa que as pessoas não queriam saber, se ganhassem,

\footnotetext{
${ }^{330}$ ENCICLOPÉDIA ITAÚ CULTURAL DE ARTES VISUAIS. Verbete Mira Schendel. Disponível em: <http://enciclopedia.itaucultural.org.br/pessoa2450/mira-schendel〉. Acesso em 16 nov. 2015.

${ }^{331}$ SCHENBERG, Mario. Monotipias de Mira Schendel. Arquivo do Centro Mario Schenberg de Documentação da Pesquisa em Arte - ECA/USP. Texto não datado.

${ }^{332}$ Para um estudo a respeito do referencial teórico compartilhado por Mario Schenberg e Mira Schendel, cf. Pismel (2013).
} 
punham no lixo". Naquele momento, "as pessoas acharam que ele era um louco, mas os cinquenta anos de história mostraram que ele tinha absoluta razão" ${ }^{333}$.

333 [Informação verbal] MAGALHÃES, Fábio. Entrevista concedida a Ana Paula Cattai Pismel. São Paulo, 5 abr. 2018. 12 arquivos .MOV (1h52'22'"). [A entrevista encontra-se depositada no Centro Mario Schenberg de Documentação da Pesquisa em Arte - ECA/USP]. 
Figura 43 - Flávio de Carvalho, Retrato de Mario Schenberg, 1968. Óleo sobre tela, 98.00 cm x $67.00 \mathrm{~cm}$. Coleção particular.

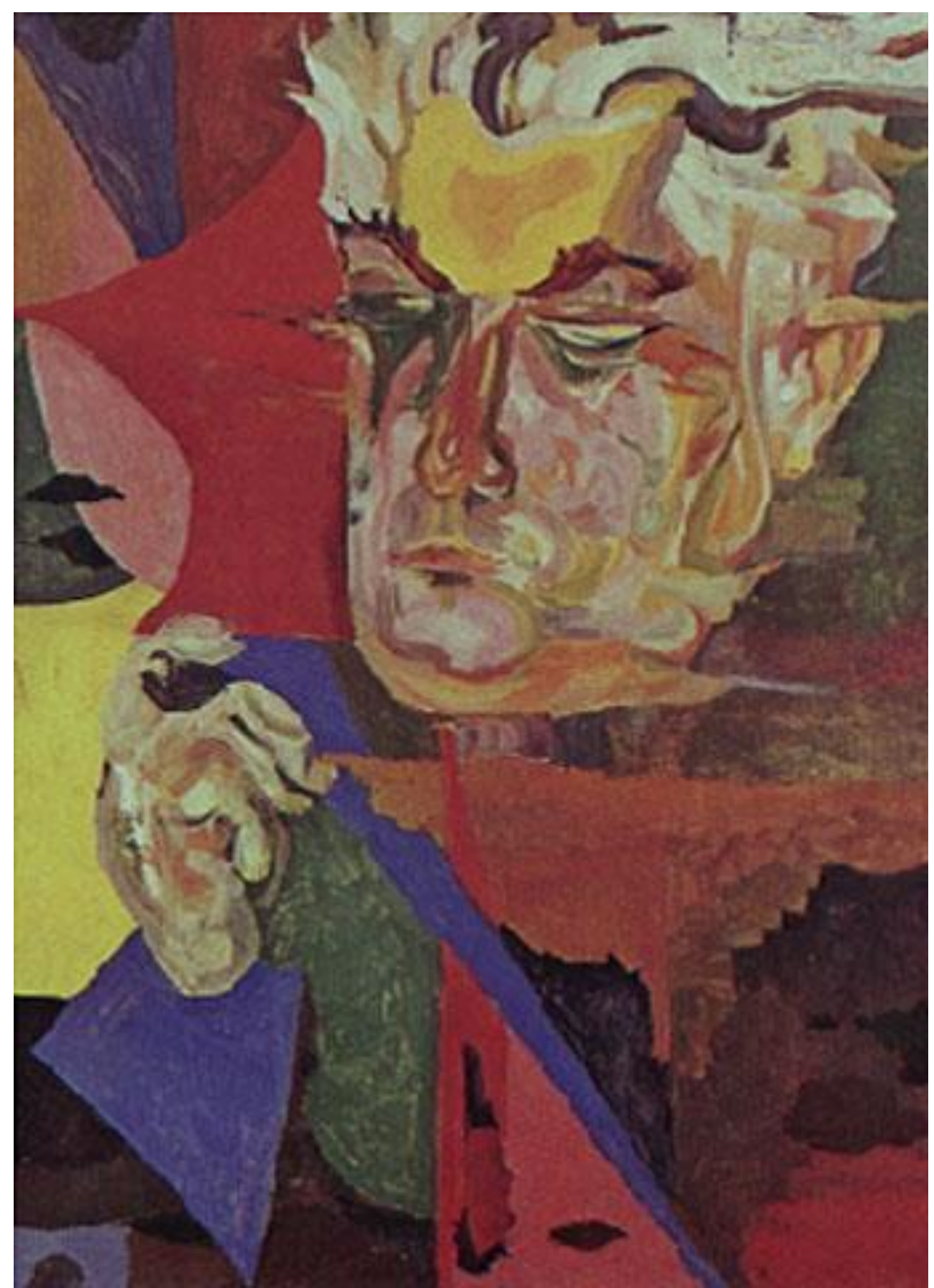

Fonte: RETRATO de Mário Schemberg. In: ENCICLOPÉDIA Itaú Cultural de Arte e Cultura Brasileiras. São Paulo: Itaú Cultural, 2018. Disponível em: <http://enciclopedia.itaucultural.org.br/obra2174/retrato-de-mario-schemberg〉. Acesso em: 10 de Jun. 2018. 
Figura 44 - O Público (1968) de Claudio Tozzi na na 10ª Bienal (1969). Autor desconhecido.

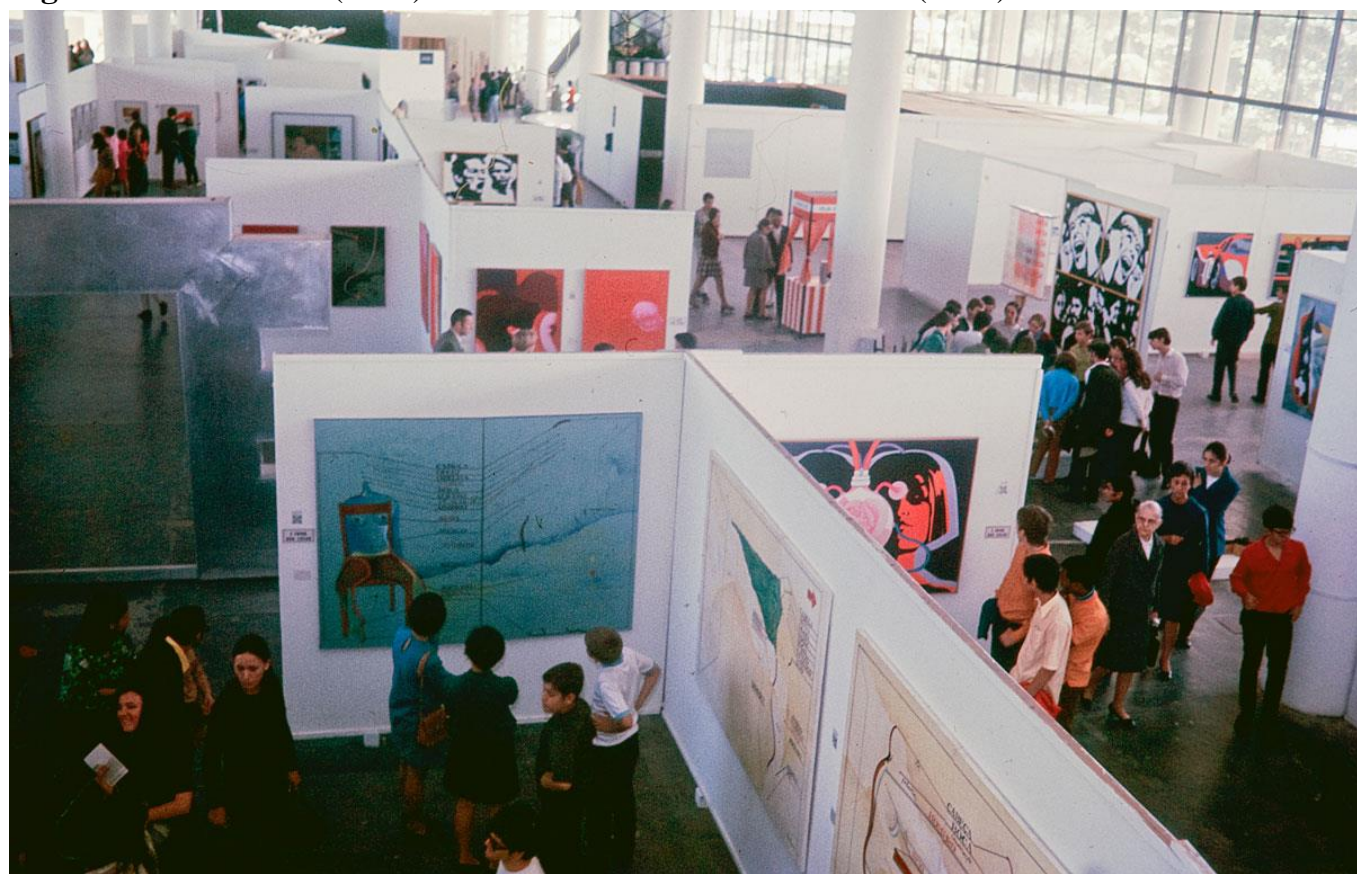

Fonte: FUNDAÇÃO BIENAL. Hoje e Antes: Um paralelo entre imagens das obras na mostra 30 $\times$ Bienal e seus primeiros registros nas Bienais passadas. 02/out./2013. Disponível em: http://www.bienal.org.br/post/263 Acesso em 12/06/2018.

Figura 45 - O Público (1968) de Claudio Tozzi na 30 × Bienal (2013) CLeo Eloy / Fundação Bienal de São Paulo.

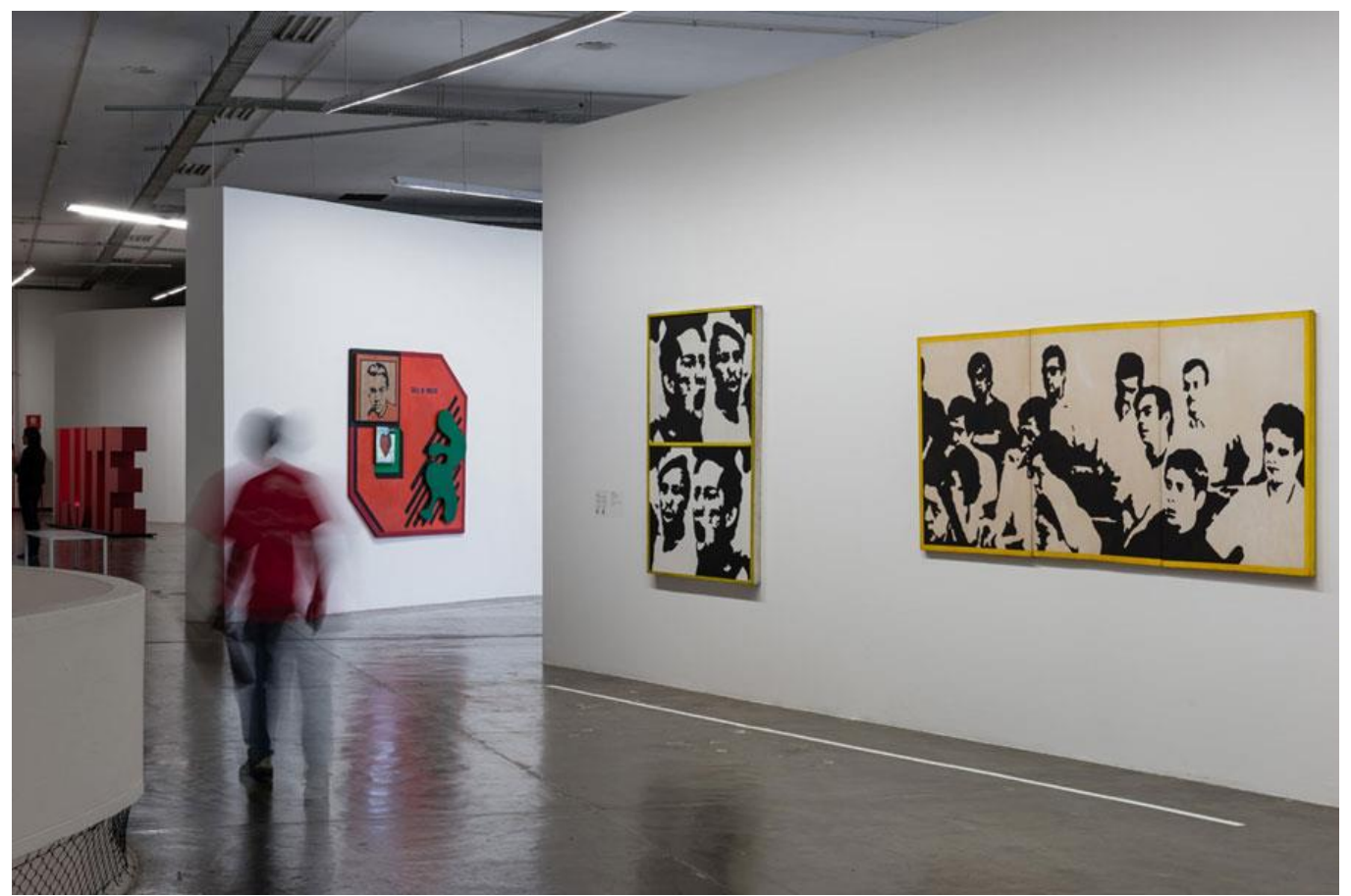

Fonte: FUNDAÇÃO BIENAL. Hoje e Antes: Um paralelo entre imagens das obras na mostra 30 $\times$ Bienal e seus primeiros registros nas Bienais passadas. 02/out./2013. Disponível em: http://www.bienal.org.br/post/263 Acesso em 12/06/2018. 
Figura 46 - Ondas paradas de probabilidade (1969) de Mira Schendel na 22a Bienal (1994). Autor desconhecido.

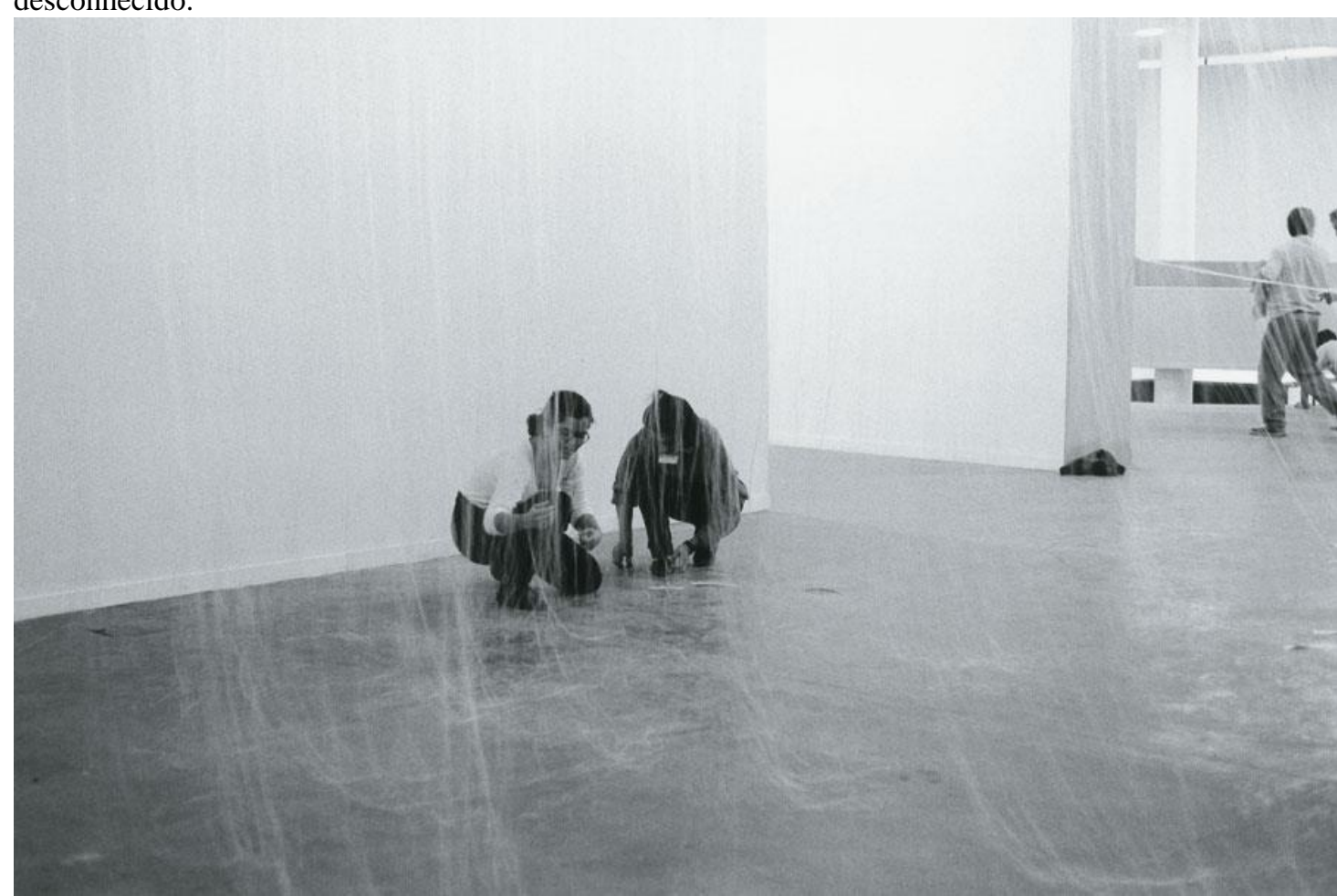

Fonte: Disponível em: http://www.bienal.org.br/post/263 Acesso em 12/06/2018.

Figura 47 - Ondas paradas de probabilidade (1969) de Mira Schendel na $30 \times$ Bienal (2013) CLeo Eloy / Fundação Bienal de São Paulo.

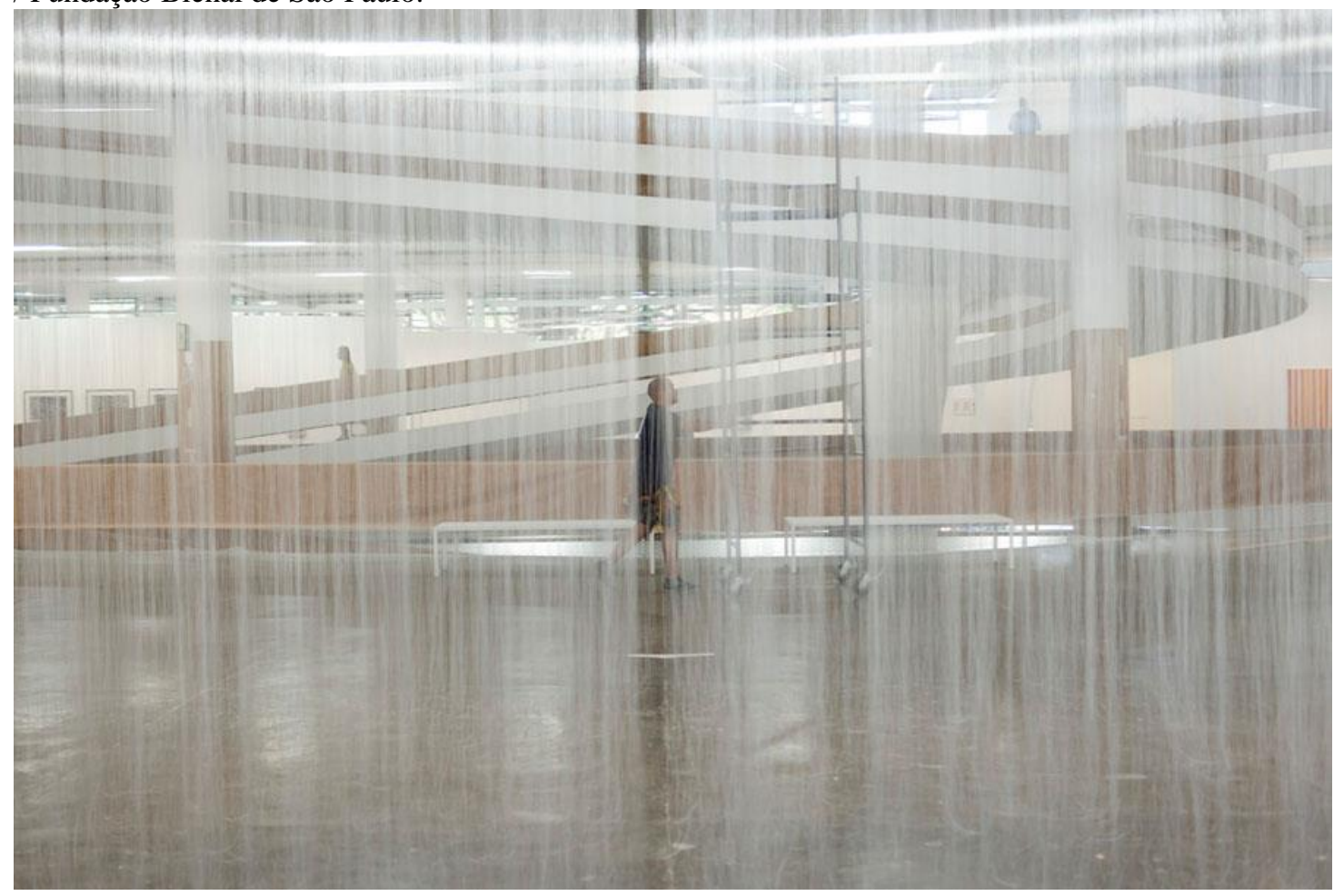

Fonte: Disponível em: http://www.bienal.org.br/post/263 Acesso em 12/06/2018. 
Figura 48 - Vista da Sala Especial: Novos Valores Brasileiros. À frente, obra de Carmela Gross, 'Espuma' (1969). Autor desconhecido.

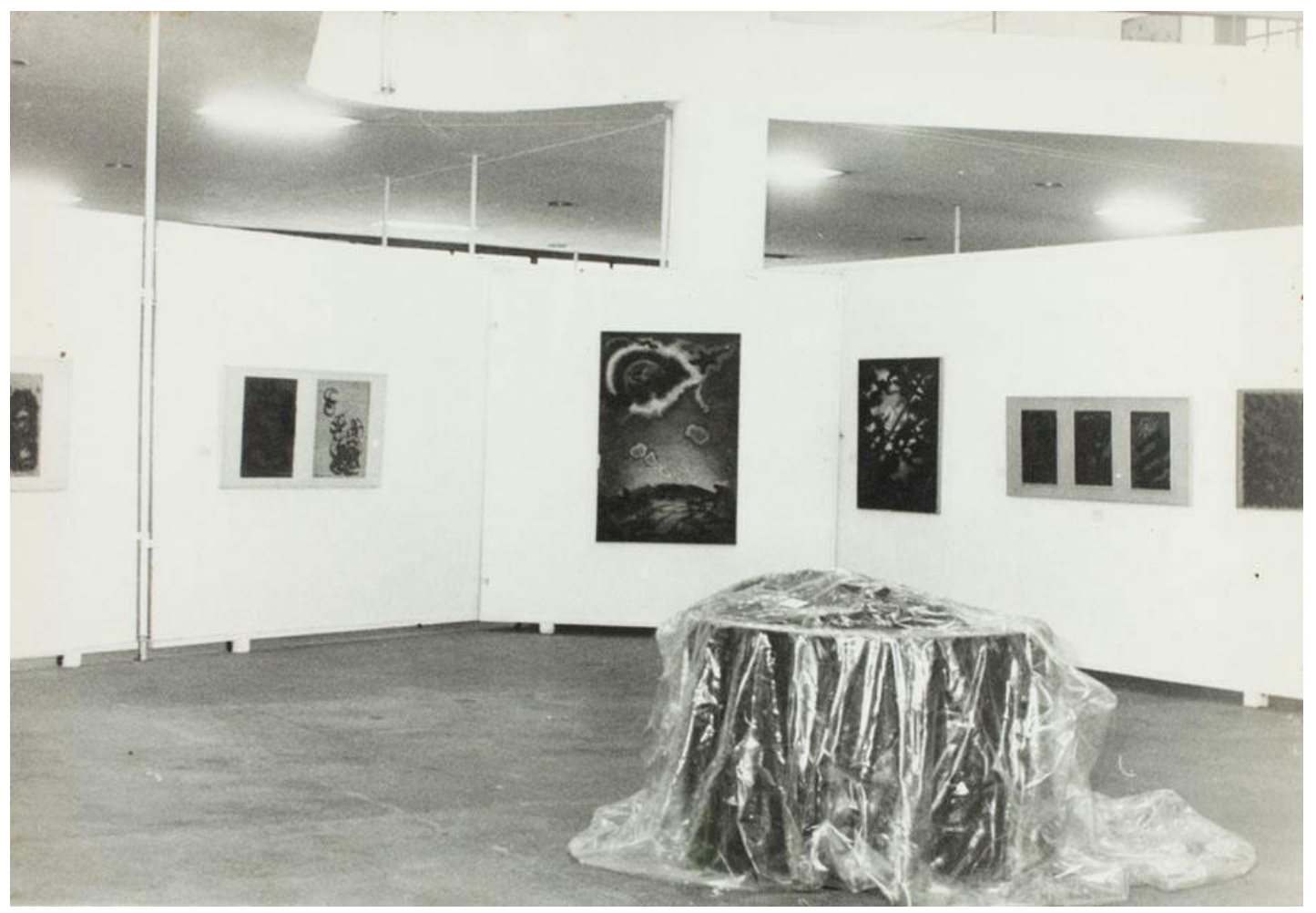

Fonte: Disponível em: http://www.bienal.org.br/post/263 Acesso em 12/06/2018.

Figura 49 - Espuma (1969) de Carmela Gross na 30 × Bienal (2013) @Leo Eloy / Fundação Bienal de São Paulo.

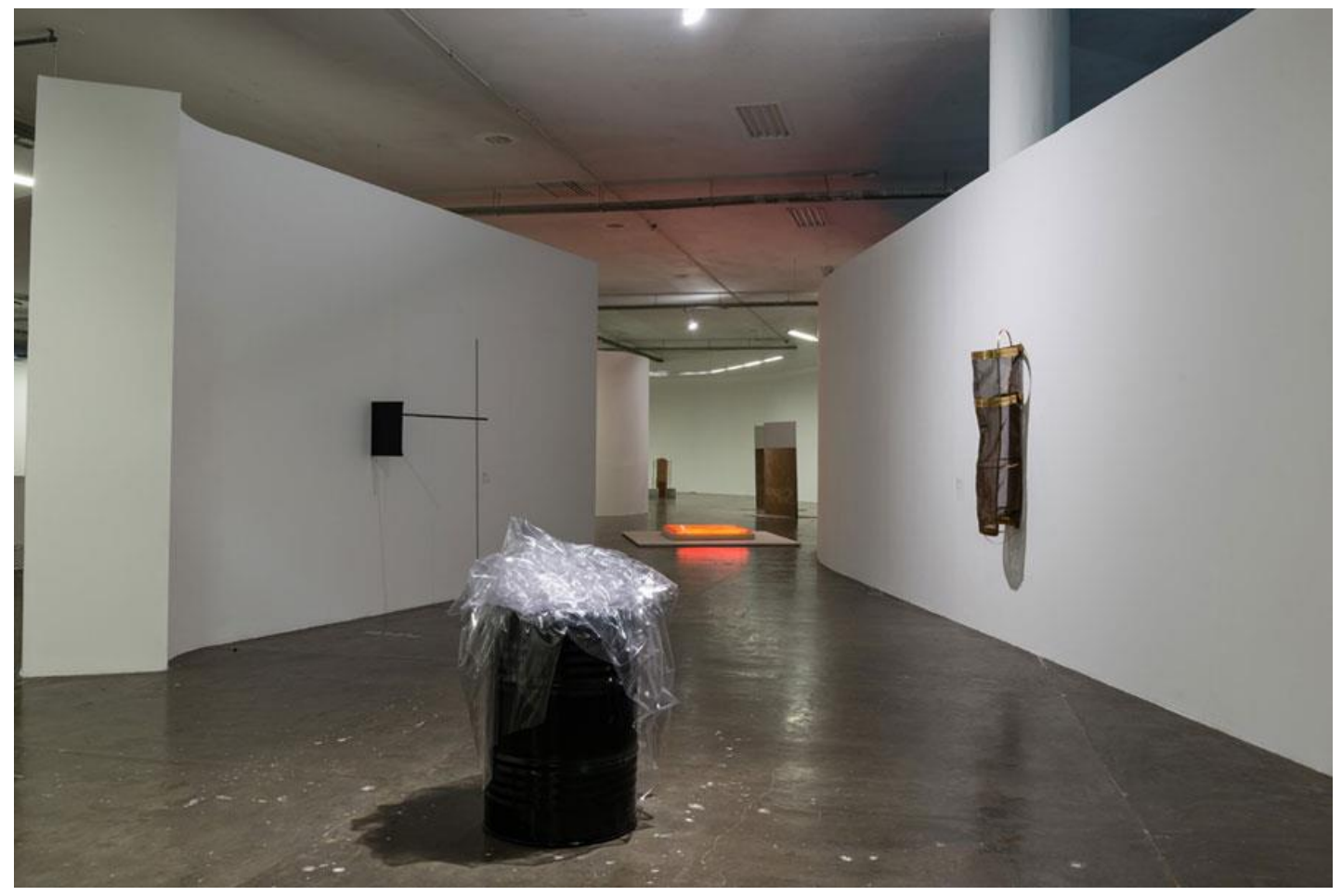

Fonte: Disponível em: http://www.bienal.org.br/post/263 Acesso em 12/06/2018. 
Figura 50 - Bolha Amarela (1967-1968) de Marcelo Nitsche na 10ª Bienal (1969)

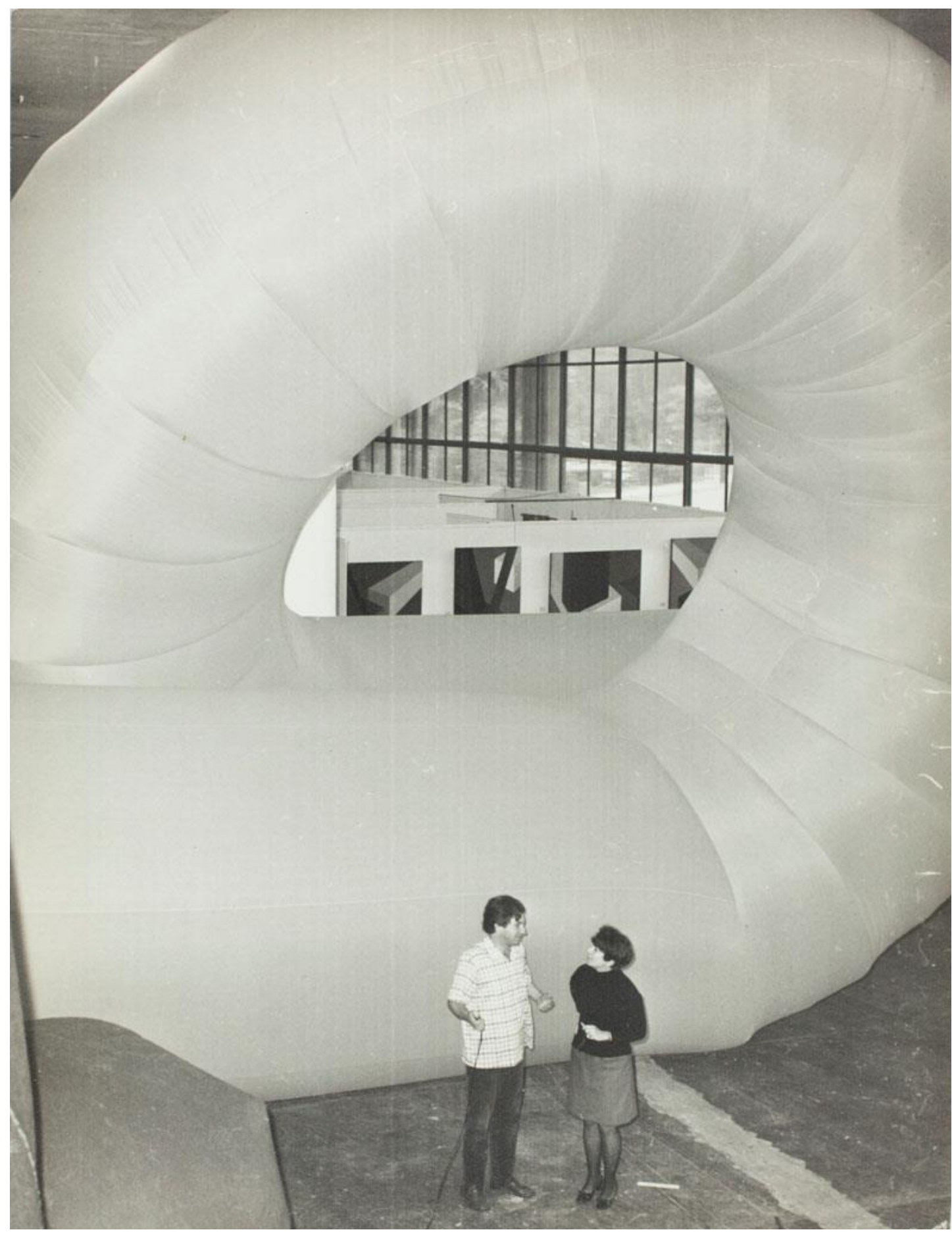

Fonte: Disponível em: http://www.bienal.org.br/post/263 Acesso em 12/06/2018. 
Figura 51 - Bolha Amarela (1967-1968) de Marcelo Nitsche na 30 × Bienal (2013) CLeo Eloy / Fundação Bienal de São Paulo

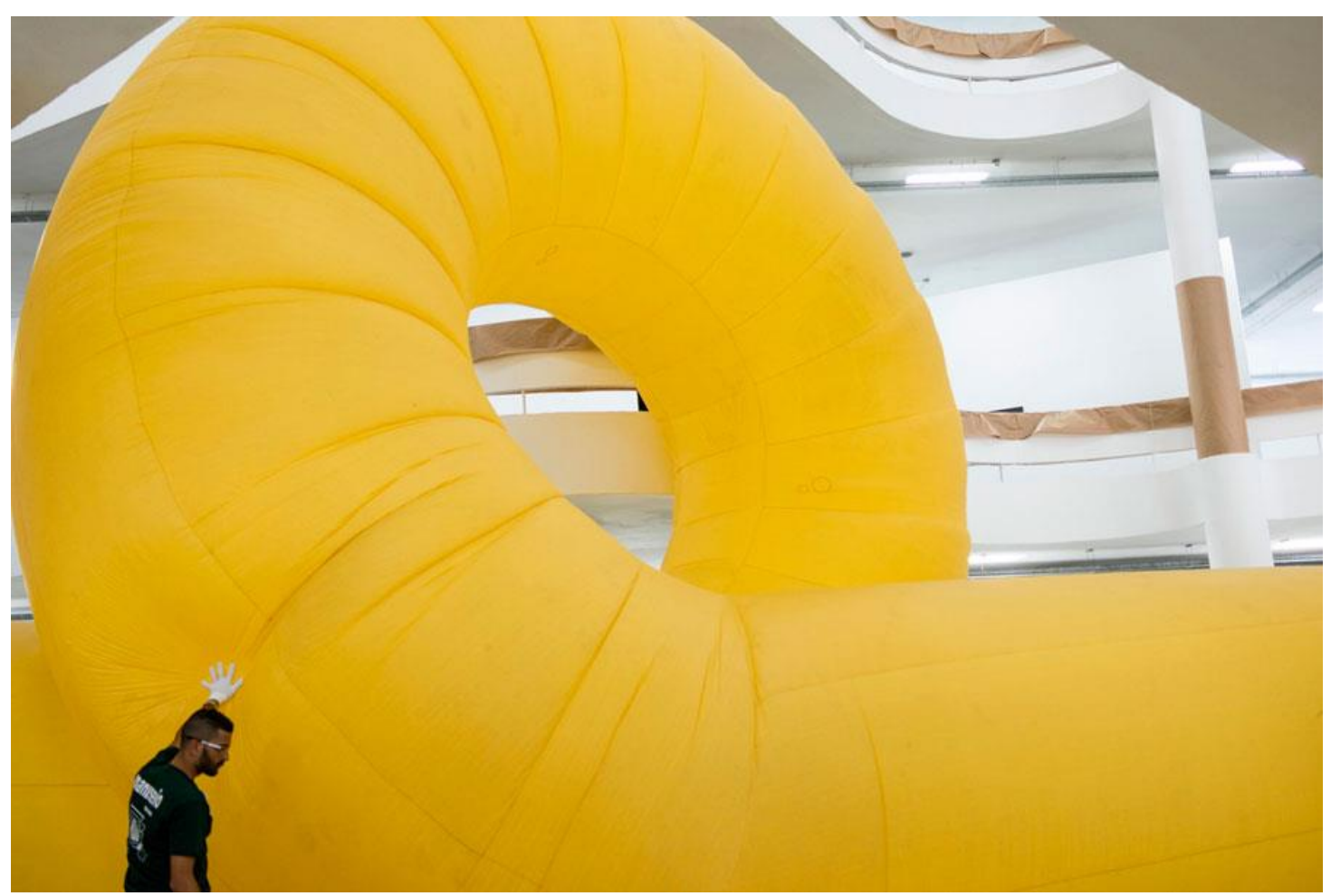

Fonte: Disponível em: http://www.bienal.org.br/post/263 Acesso em 12/06/2018. 
Figura 52 - Vista geral da $10^{\mathrm{a}}$ Bienal. Autor não identificado.

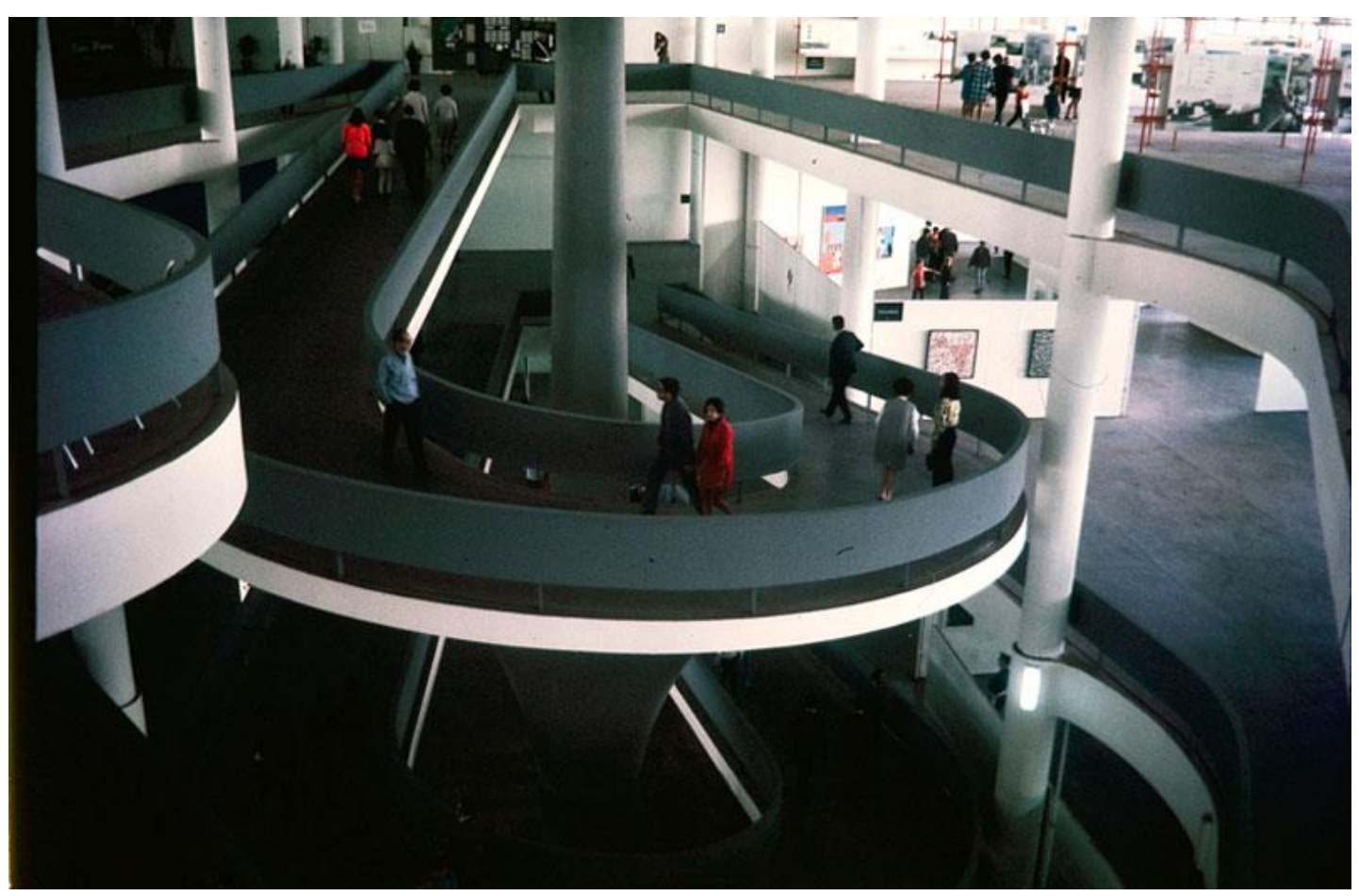

Fonte: FUNDAÇÃO BIENAL DE SÃO PAULO. 10ª Bienal de São Paulo. Disponível em: http://www.bienal.org.br/exposicoes/10bienal/fotos/3892 Acesso em 12/06/2018.

Figura 53 - Fachada da $10^{\mathrm{a}}$ Bienal. Autor não identificado.

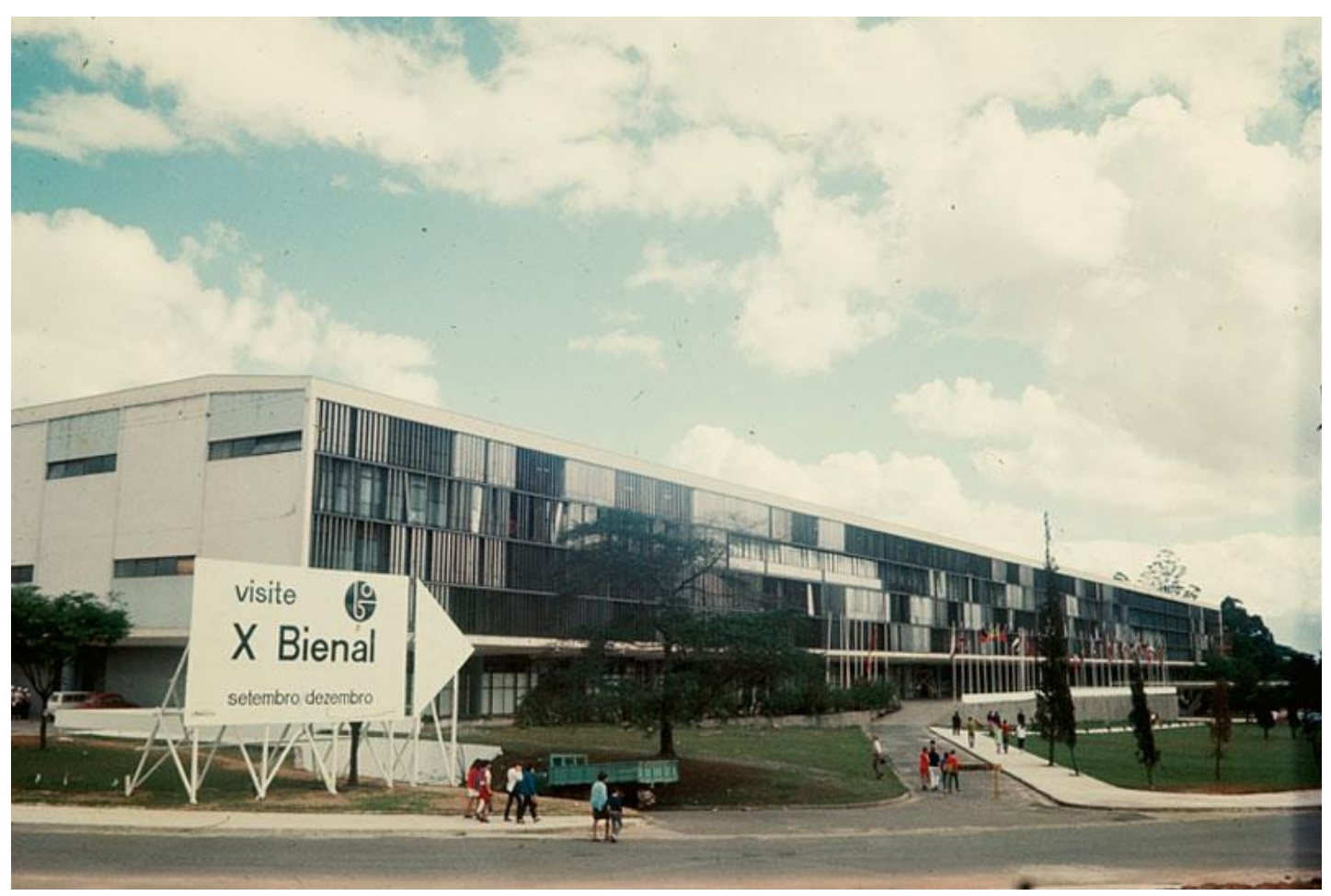

Fonte: FUNDAÇÃO BIENAL DE SÃO PAULO. 10a Bienal de São Paulo. Disponível em: http://www.bienal.org.br/exposicoes/10bienal/fotos/3894 Acesso em 12/06/2018. 


\section{Mesas e Seminários: o lugar do debate}

O discurso aberto é um apelo à responsabilidade, à escolha individual, um desafio e um estímulo para o gosto, para a imaginação, para a inteligência. Por isso a grande arte é sempre difícil e sempre imprevista, não quer agradar e consolar, quer colocar problemas, renovar a nossa percepção e o nosso modo de compreender as coisas. ${ }^{334}$

Umberto Eco

Só pela ciência e pela arte as civilizações têm valor. ${ }^{335}$

Henri Poincaré

\section{Mesas Redondas da AICA (1969 e 1971)}

X Bienal (1969): Mesa redonda da AICA

Como membro do Júri de Seleção da X Bienal, Mario Schenberg participou, ainda, de uma Mesa Redonda, para a qual foram convidados críticos de arte do Brasil e do exterior. O evento foi realizado no auditório da Fundação Bienal, nos dias 27 e 28 de setembro de 1969. A coordenação da mesa redonda ficou a cargo do crítico Sérgio Ferro e seu objetivo era discutir aspectos da organização e da premiação das bienais, com vistas a sua reformulação ${ }^{336}$.

334 ECO, Umberto. Entrevista com Umberto Eco. In ECO, Umberto. Obra aberta: formas e indeterminação nas poéticas contemporâneas. Tradução: Giovanni Catulo et al. $10^{a}$ edição. São Paulo: Perspectiva, 2015, p. 344 (publicada originalmente no Suplemento Literário do jornal O Estado de São Paulo em 17 set. 1966). O autor foi entrevistado por Augusto de Campos quando de sua estadia na cidade de São Paulo. Note-se que, nesse período, Umberto Eco e Mario Schenberg se conheceram.

335 POINCARÉ, Henri. O valor da ciência. Rio de Janeiro: Contraponto, 1995, p. 172.

336 Críticos de Arte vão debater reformulação das bienais. Nota enviada à imprensa, documento não datado. Arquivo Histórico Wanda Svevo, Fundação Bienal. 
Walmir Ayala afirma ${ }^{337}$, no artigo A Bienal em Questão, que o modelo adotado pela Bienal não correspondia mais

à evolução do espírito criador contemporâneo e, como tantas outras organizações sócio-festivas, de promoção artística, estaria corrompida do maneirismo burguês, entre o balanço do comércio, a nutrição do veditismo, o delírio da sofisticação e a ronda da politicagem.

A inadequação da Bienal de São Paulo às mudanças que aconteceram na arte durante os anos de 1960 também dava o tom de outras discussões: a escolha do Júri de Premiação, seus critérios de decisão e, no limite, a própria existência das premiações, consideradas opulentas, foram alguns dos itens do temário da Mesa Redonda. Foram postos em discussão, ainda, o modelo das representações divididas por países (e não por tendências), bem como a inexistência de uma instância diretiva formada por conhecedores de arte na organização ${ }^{338}$.

Poucos dias antes da realização da Mesa Redonda, muitos críticos de arte brasileiros se recusaram a participar dos seminários, manifestando descontentamento pelo fato de não terem recebido convite oficial com antecedência. A ABCA entendeu o fato como descaso quanto à participação dos críticos de arte do país. Afirmava que a sugestão do evento teria partido da ABCA e da AIAP, mas ressurgia "inteiramente desvirtuada" 339 , o que demonstrava a direção amadorística da Bienal. Criticava também a inclusão à revelia de alguns críticos na lista de nomes para o evento, paralelamente à exclusão de vários outros ${ }^{340}$.

Estruturalmente, o evento se dividiu em dois momentos: no primeiro dia, cuja programação teve início às $17 \mathrm{~h}$, foram apresentadas quatro comunicações que deram

\footnotetext{
${ }^{337}$ Walmir Ayala, A Bienal em Questão. Jornal do Brasil (Rio de Janeiro), 27 set. 1969.

${ }^{338}$ Sobre as críticas a respeito da gestão e organização das Bienais, cf. Mário Barata. Aspectos Organizativos da Bienal. Jornal do Comércio (Rio de Janeiro), 12 out. 1969; Walmir Ayala. Júris, pra quê? Jornal do Comércio (Rio de Janeiro), 14 out. 1969 e Arnaldo Pedroso D'Horta. Ainda a Bienal. Jornal da Tarde (São Paulo), 22 out. 1969.

${ }^{339}$ Cf. telegrama assinado pelos críticos Pedro Manuel Gismondi, Antônio Bento, Aracy Amaral, Maria Eugênia Franco, José Roberto Teixeira Leite, Theon Spanudis, Waldemar Cordeiro e Walter Zanini, datado de 25 set. 1969 (Arquivo Histórico Wanda Svevo, Fundação Bienal), que foi publicado no Diário de Notícias (Rio de Janeiro) em 3 out. 1969, em nota de Frederico Morais, intitulada Mesa Redonda e Protesto. Vale lembrar que já em 1965 foi feita a proposta de realização de um simpósio de críticos de arte a fim de repensar a estrutura da Bienal. Cf. Vera Pacheco Jordão. Os críticos e a Bienal. O Globo (Estado da Guanabara), 17 ago. 1965.

${ }^{340}$ No mesmo dia, Edyla Mangabeira Unger (membro do júri de seleção e da comissão técnica) fez saber à Fundação Bienal que, devido ao fato de seus colegas da ABCA não terem sido convidados com a devida antecedência, não participaria da Mesa Redonda. Cf. telegrama datado de 25 set. 1969, Arquivo Histórico Wanda Svevo, Fundação Bienal.
} 
início ao exame do temário: Riszard Stanislawsky, da Polônia, falou sobre a "Finalidade das exposições Internacionais"; Hernandez Campos, do México, sobre "Organização das Exposições Internacionais"; Yona Fischer, de Israel, sobre "Os críticos de premiação" e, finalmente, Mario Schenberg falou sobre o "Apoio à pesquisa em arte". Cada um deles teve a palavra durante vinte minutos, após o que se seguiu um pequeno debate. ${ }^{341}$

No dia seguinte, foi realizada pela manhã, às $10 \mathrm{~h}$, uma rodada de debate da crítica especializada. Às $16 \mathrm{~h}$ tiveram lugar reuniões entre os críticos e às $17 \mathrm{~h}$ uma plenária para aprovação de redação das recomendações da Mesa Redonda. A coordenação dos debates foi feita pelo crítico Marc Bercowitz, que representava o Brasil no júri internacional de seleção ${ }^{342}$.

Os debates foram registrados em ata, que não foi localizada no Arquivo Histórico Wanda Svevo. Sem esse documento, não foi possível reconstituir a fala de Mario Schenberg, nem suas intervenções nos debates ocorridos. Contudo, em sua manifestação na Mesa Redonda de 1971, também organizada pela Fundação Bienal, o crítico indica que já se tinha "pensado nos mesmos problemas na mesa redonda anterior. Infelizmente, como acontece aqui na Bienal, todas as sugestões são engavetadas" ${ }^{343}$. A fala dá uma pista de seu posicionamento.

Foi elaborado, ao final da Mesa Redonda, um documento contendo as observações dos críticos de arte. As recomendações não se referiam apenas à Bienal de São Paulo, como também às demais grandes exposições do circuito internacional. Entre as principais delas, constavam: a manutenção das representações por país (dado que não havia outra maneira de garantir igualdade de oportunidade a países de diferentes situações econômicas e culturais de exporem sua produção artística); a abertura à realização de manifestações como happenings e arte que envolva participação humana; a contribuição para a ampliação das possibilidades artísticas e à plena liberdade de sua manifestação ${ }^{344}$.

\footnotetext{
${ }^{341}$ Cf. Regimento Interno do evento. Documento não datado, Arquivo Histórico Wanda Svevo, Fundação Bienal. O evento era aberto ao público, mas este não tinha voz. Contudo, era possível que ele se manifestasse por escrito, sendo as sugestões depositadas em urnas destinadas a esse fim.

${ }^{342}$ Programação da Mesa Redonda de Críticos de Arte - X Bienal.

${ }^{343}$ Mario Schenberg. Transcrição de sua intervenção na Mesa Redonda de 1971. Documento não datado, p. 7. Arquivo Histórico Wanda Svevo, Fundação Bienal (foi mantida a grafia original do texto).

${ }^{344}$ Recomendações da Mesa Redonda de críticos de arte internacionais. Documento não datado, com duas páginas. Arquivo Histórico Wanda Svevo, Fundação Bienal.
} 
Entre as outras recomendações, chamaram atenção as seguintes: a promoção de condições para que artistas desenvolvam pesquisas por meio da criação, de modo semelhante ao que já ocorria na pesquisa acadêmica (concessão de bolsas e fundos de fomento por parte de instituições de diversos países); a formação de uma comissão coordenadora para levar adiante a consulta aos meios especializados com relação às recomendações (essa comissão trabalharia com a direção da Fundação Bienal) ${ }^{345}$.

Ao fim dessa longa lista, era ressaltado ainda que a permanência das representações nacionais e a reformulação da premiação foram os pontos mais controversos. A primeira, pelo motivo já explicitado; a segunda, por não ter havido concordância entre as diversas possibilidades apresentadas ${ }^{346}$.

A presença de uma recomendação sobre o fomento à pesquisa artística entre as resoluções finais do evento parece indicar que a fala de Mario Schenberg no primeiro dia dos trabalhos teve repercussão. O tema de sua comunicação (apoio à pesquisa em arte), somado à sua vivência no campo da pesquisa científica e à defesa da necessidade de incentivar os artistas jovens, própria do crítico, foram os elementos que levaram a essa posição. Infelizmente, como já foi dito, não foram encontradas as transcrições dos debates realizados para tecer considerações mais precisas.

Contudo, não se pode deixar de traçar um paralelo entre a atuação de Mario Schenberg na política universitária, sempre em defesa da criação de condições para garantir liberdade e autonomia para os pesquisadores. Isso porque, para o cientista, somente com mais liberdade e menos burocracia seria possível criar o terreno para novas ideias que, por sua vez, pudessem contribuir para o avanço da ciência ${ }^{347}$ e da arte.

XI Bienal (1971): Mesa redonda da AICA

A XI Bienal esteve aberta ao público entre 4 de setembro e 15 de novembro de 1971, trazendo 351 artistas de 57 países, num total de 2.459 obras. A comissão técnica

\footnotetext{
${ }^{345}$ Recomendações da Mesa Redonda de críticos de arte internacionais. Documento não datado, com duas páginas. Arquivo Histórico Wanda Svevo, Fundação Bienal.

${ }^{346}$ Recomendações da Mesa Redonda de críticos de arte internacionais. Documento não datado, com duas páginas. Arquivo Histórico Wanda Svevo, Fundação Bienal.

${ }^{347}$ Schenberg, Mario. Formação da Mentalidade Científica. In Estudos Avançados, 12(5), 1991, pp. 123 151.
} 
que organizou a mostra de artes visuais foi composta por Antônio Bento, Geraldo Ferraz e Sérgio Ferro ${ }^{348}$.

Para Aracy Amaral, essa edição marcou o início dos "anos baixos" das Bienais, na medida em que, cada vez mais, Ciccilo Matarazzo delegava a amigos empresários, e não a profissionais especializados, a concepção do evento ${ }^{349}$. Embora algumas mudanças tivessem ocorrido, como, por exemplo, a realização de Pré-Bienais, que tentou responder ao criticado modelo de escolha anterior, muitos outros pontos de seu funcionamento ainda eram postos em xeque por artistas e críticos de arte.

Alguns deles, como a ausência de uma direção geral competente que conferisse unicidade à mostra internacional, eram apontados desde que as bienais foram desvinculadas do MAM-SP. Era forte, ainda, a constatação de que as bienais não estavam sendo capazes de acompanhar os desdobramentos mais recentes da arte contemporânea que, a partir da segunda metade da década anterior, sofrera transformações profundas, como a desconstrução dos suportes tradicionais e a arte conceitual, por exemplo.

Além disso, ecos do boicote internacional se faziam sentir mais profundamente nessa edição. Os Estados Unidos se retiraram da mostra e França, Itália e Grã-Bretanha tiveram poucos artistas. No ano anterior, Mário Pedrosa tinha se exilado no Chile devido à ameaça de prisão, contra o que protestaram artistas como Pablo Picasso, Alexander Calder, Max Bill e Henry Moore ${ }^{350}$.

A linha geral da XI Bienal foi a comemoração dos vinte anos da mostra, realizada em clima retrospectivo, homenageando a si própria. Nesse espírito, foram organizadas diversas salas especiais dedicadas a artistas premiados desde 1951, contrariando o propósito maior do certame: dar visibilidade às tendências mais recentes da arte nacional e internacional.

Nessa ocasião, Mario Schenberg não integrou o Júri de Seleção, mas fez parte de uma Mesa Redonda semelhante à realizada na Bienal anterior. De acordo com o

\footnotetext{
${ }^{348}$ FUNDAÇÃO BIENAL. Bienal a Bienal. Disponível em: $\langle$ http://www.bienal.org.br/FBSP/pt/AHWS/BienalaBiena//Paginas/6BienalSaoPaulo.aspx?selected=6>. Acesso em 15 jan. 2013.

349 AMARAL, Aracy. Bienais ou da impossibilidade de reter o tempo. REVISTA USP, São Paulo, n. 52, p. 16-25, dez./fev. 2001-2002.

${ }^{350}$ ALAMBERT, Francisco \& CANHÊTE, Polyana. Bienais de São Paulo: da era do museu à era dos curadores. São Paulo: Boitempo, 2004.
} 
depoimento já citado, Schenberg ${ }^{351}$ aponta o motivo pelo qual não pôde continuar envolvido na organização das edições posteriores à de 1969:

Eu, que já tinha organizado a primeira exposição de Volpi em 1944, organizei em 61 a sua primeira retrospectiva. Depois disso, começaram a votar para que eu fizesse parte dos júris de seleção das Bienais. O primeiro júri que integrei foi em 1965, depois 67 e 69 . E, a partir daí, a Bienal me aplica o Ato 75.

Nesse sentido, cabe perguntar o que foi o Ato 75 e como ele impediu o crítico de continuar participando dos júris. Teria ele participado do Júri se a Bienal não tivesse lhe aplicado o Ato? O depoimento dá a entender que Mario Schenberg teria sido eleito pelos artistas, mas sua atuação foi impedida pela Bienal. As considerações a seguir tentarão dar conta dessas dúvidas, na medida do possível.

Primeiramente, é preciso observar que o crítico se refere ao Ato Complementar Número 75, editado em 21 de outubro de 1969, que decretava:

Todos aqueles que, como professor, funcionário ou empregado de estabelecimento de ensino público, incorreram ou venham a incorrer em faltas que resultaram ou venham a resultar em sansões com fundamento em Atos Institucionais, ficam proibidos de exercer, a qualquer título, cargo, função, emprego ou atividades, em estabelecimentos de ensino e em fundações criadas ou subvencionadas pelos Poderes Públicos, tanto da União, como dos Estados, Distrito Federal, Territórios e Municípios, bem como em instituições de ensino ou pesquisa e organizações de interesse da segurança nacional ${ }^{352}$.

Funcionando como uma espécie de arremate do AI 5, o Ato Complementar 75 fechava as portas do mercado de trabalho aos professores universitários que foram objeto de perseguição do regime militar. Isso porque não existiam instituições de ensino e de pesquisa que, de alguma forma, não recebessem algum tipo de verba ou subvenção pública $^{353}$.

${ }^{351}$ SCHENBERG, Mario. Depoimento. In AJZNBERG, Elza. Schenberg - Arte e Ciência. São Paulo: ECA/USP, 1995, p. 142.

352 ATO Complementar $\mathbf{n}^{\mathbf{7}} \mathbf{7 5}$, de 21 out. 1969, Diário Oficial da União, p. 8930. Disponível em: <http://www.planalto.gov.br/ccivil_03/ACP/acp-75-69.htm〉. Acesso em: 20 fev. 2013. Esse Ato Complementar foi assinado por Luiz Antônio da Gama e Silva, que foi reitor da Universidade de São Paulo e assinou também o AI-5, e por Antônio Delfim Neto, docente da Faculdade de Economia e Administração da USP. Agradecimentos são devidos ao Prof. Dr. Francisco Alambert pelo auxílio e pelas conversas a respeito do aspecto social e político desse período.

${ }^{353}$ CLEMENTE, José Eduardo Ferraz. Ciência e política durante a ditadura militar: o caso da comunidade brasileira de físicos (1964-1979). Salvador: Universidade Federal da Bahia, Instituto de Física, 2005. (dissertação de Mestrado), p. 128-29. 
Mario Schenberg, que desde sua aposentadoria compulsória dava seminários semanais no Centro Brasileiro de Pesquisas Físicas, sediado no Rio de Janeiro, foi dispensado da instituição, que se enquadrava nos termos desse Ato Complementar. Levando-se em consideração que a Fundação Bienal era financiada por verbas estaduais e municipais, pode-se compreender o motivo pelo qual suas portas também se fecharam ao crítico. Em entrevista ao jornal Folhetim em 1977, Mario Schenberg ${ }^{354}$ definiria suas limitações de maneira bastante clara:

\begin{abstract}
A aposentadoria dos professores é regulamentada por um ato complementar drástico que não nos permite trabalhar mais em quase nada: não podemos mais trabalhar em nenhuma universidade do País, ou em organizações particulares que recebem auxílio do governo. Assim, não temos mais acesso a laboratórios e bibliotecas, não podemos mais assistir seminários, participar de debates etc., promovidos dentro dessas instituições.
\end{abstract}

A partir disso, já se sabe que, mesmo que o crítico tivesse sido escolhido pelos artistas, estava impedido de atuar na Fundação Bienal. Mas resta saber se ele de fato foi o vencedor da eleição, que voltou a ser promovida pela própria instituição.

Para entender como funcionou o júri da IX Bienal, é necessário ter em vista que, em 1970, teve lugar a I Pré-Bienal de São Paulo, conforme já foi apontado, no período que foi de 12 de setembro a 25 de outubro de 1970. Essa nova estrutura de seleção mudou o modo de escolha do Júri de Seleção da Bienal Internacional.

A mostra teve o intento de reunir manifestações artísticas de todas as partes do país, tirando a participação brasileira nas bienais internacionais do eixo Rio-São Paulo. Para isso, foram realizadas seleções em diferentes estados. A região Nordeste, por exemplo, chegou a organizar uma "pré-pré-bienal", realizando uma exposição que reunia os artistas cujos trabalhos seriam submetidos ao Júri de Seleção itinerante.

Com as diversas pré-seleções, foi necessário que os membros do Júri se deslocassem pelo Brasil, o que tornou os trabalhos mais dispendiosos. O corpo de jurados teve variações da localidade para localidade, mantendo sempre um representante da Fundação Bienal. Foram realizadas seleções locais em Manaus, Belém, Recife, Belo Horizonte, Goiânia, Brasília, Campo Grande, Guanabara (atual Rio de Janeiro), São Paulo, Curitiba, Florianópolis e Porto Alegre ${ }^{355}$.

\footnotetext{
${ }^{354}$ Mario Schenberg. Jornal Folhetim, 24 jul. 1977.

355 "Pré-Bienal começa no dia 12 com artistas de 21 estados". Nota divulgada à imprensa, datilografada, datada de 3 set. 1970. Arquivo Histórico Wanda Svevo, Fundação Bienal.
} 
Mario Schenberg, que não concordou com a criação das Pré-Bienais, não fez parte desse Júri itinerante. Apesar de ser natural supor que, por isso, o crítico não tenha participado das diversas seleções, não há certeza sobre esse ponto, pois não foi encontrada documentação que forneça maiores detalhes a esse respeito.

Pouco antes da abertura da I Pré-Bienal, todos os artistas que haviam sido selecionados para a mostra foram convocados a enviar seus votos para o Júri de Seleção. Dessa vez, para o da IX Bienal de São Paulo. Dentre os quase 258 artistas, que apresentaram 1.300 obras, seriam escolhidos inicialmente 25 para a representação brasileira na mostra internacional ${ }^{356}$. Por sugestão da AIAP foram convidados mais 5 $\operatorname{artistas}^{357}$.

Os votos foram apurados no dia 31 de setembro de 1970: Lisetta Levi teve 56 votos e foi eleita. Mario Schenberg teve 15 votos (dois de Florianópolis e 13 de São Paulo $)^{358}$. Depois da apuração, contudo, ainda chegaram alguns votos, sendo que quatro deles eram para o crítico, todos vindos de Recife, Pernambuco, seu estado natal. Mesmo que tivessem sido contabilizados na apuração, não seriam suficientes para elegê-lo ${ }^{359}$.

O corpo de jurados da XI Bienal de São Paulo, que passava a ser internacional, teve a seguinte constituição: James Johnson Sweeney (Estados Unidos), Romero Brest (Argentina), Hugo Auler e Marc Bercowitz (indicados pela Fundação Bienal) e Lisetta Levi (eleita pelos artistas). Outra novidade foi a designação de um coordenador geral para a representação brasileira: Geraldo Ferraz.

A configuração final da representação nacional na XI Bienal foi a seguinte: 30 artistas selecionados na Pré-Bienal, aos quais se acrescentaram outros 60, distribuídos nas salas especiais "Vinte anos de Bienal", "Proposições" e "Didática da Gravura"360.

Por fim, é importante notar que o Ato Complementar 75 foi decretado semanas antes do término da X Bienal, o que aconteceu em 14 de dezembro de 1969. Por isso, é provável que, dois anos depois, esse impedimento já fosse de conhecimento público do

\footnotetext{
356 "Regulamento da Pré-Bienal de São Paulo". Documento datilografado, datado de 20 jan. 1970. Arquivo Histórico Wanda Svevo, Fundação Bienal.

357 "Júri já escolheu artistas brasileiros para a Bienal Internacional de Artes". Nota divulgada à imprensa. Documento datilografado, datado de 11 set. 1970. Arquivo Histórico Wanda Svevo, Fundação Bienal.

${ }^{358}$ Segundo a apuração: Lisetta Levi (56 votos), Geraldo Ferraz (48), Morgan Motta e Maristela Tristão (21), Frederico Morais e José Geraldo Vieira (17), Oswald de Andrade Filho, Mário Barata e Quirino Campofiorito (16) e Mario Schenberg (15); outros nomes citados em ata receberam menos votos. Ata da apuração da eleição do representante dos artistas no Júri de Seleção da XI Bienal. Documento manuscrito, datado de 31 ago. 1970. Arquivo Histórico Wanda Svevo, Fundação Bienal.

${ }^{359}$ Cf. telegramas datados de 3 e 4 ago. 1970. Arquivo Histórico Wanda Svevo, Fundação Bienal.

360 "Relatório das Atividades em 1971". Documento datilografado, datado de janeiro de 1972. Arquivo Histórico Wanda Svevo, Fundação Bienal.
} 
meio artístico. Sabendo disso, os artistas poderiam ter redirecionado suas opções, até mesmo para resguardar a figura de Mario Schenberg, tendo em vista o acirramento das ações repressivas do regime militar. Outra possibilidade para esse resultado seria a nova distribuição demográfica da eleição que, saindo do eixo Rio-São Paulo (no qual Mario Schenberg era mais conhecido), poderia ter influenciado o resultado.

Mesa-Redonda da AICA (1971): presença improvável

Diante do que foi visto, é relevante notar que Mario Schenberg participou de uma Mesa Redonda de Críticos de Arte, mesmo sem ter feito parte do Júri de Seleção. Participaram do evento cerca de 120 convidados, entre críticos e artistas, representantes de 25 países $^{361}$. Novamente, os debates foram iniciados juntamente com a inauguração da XI Bienal de São Paulo, no dia 4 de setembro de 1971. Antônio Bento coordenou a participação brasileira na Mesa Redonda, enquanto Walter Zanini coordenou e secretariou os debates.

A crise da Bienal foi discutida a partir de um quadro mundial de declínio das grandes exposições internacionais ${ }^{362}$. Mais uma vez, a falta de uma direção artística (que já tinha sido apontada em 1969) foi criticada. Os temas dessa discussão foram a reformulação das bienais (novamente), a relação emergente da Arte com a Comunicação e com a Tecnologia. A fala de Mario Schenberg, gravada e transcrita, passou por esses três eixos. Sua comunicação ${ }^{363}$ é relevante para a compreensão de sua visão acerca dos temas já citados, pois foram tecidas ali relações conceituais que jogam luz sobre alguns aspectos de seu pensamento ${ }^{364}$.

O crítico atribui a crise da Bienal a uma insistência na tradição museológica que, extremamente preocupada com os objetos, teria se tornado inadequada em vista da emergência de formas de expressão cada vez mais ligadas à Arte Conceitual. Para ele, a "finalidade da arte é produzir valores, não objetos", embora o crítico reconheça que o

361 "Relatório das Atividades em 1971". Documento datilografado, datado de janeiro de 1972. Arquivo Histórico Wanda Svevo, Fundação Bienal.

${ }^{362}$ ALAMBERT, Francisco \& CANHÊTE, Polyana. Bienais de São Paulo: da era do museu à era dos curadores. São Paulo: Boitempo, 2004, p. 135.

363 "Mario Schenberg". Documento datilografado, não datado, 7 páginas. Arquivo Histórico Wanda Svevo, Fundação Bienal.

${ }^{364}$ Nesse ponto é apresentada uma versão ampliada em relação à que integrou a dissertação de mestrado. Cf. Pismel, 2013. 
objeto tem uma função importante na criação desses novos valores no caso das artes plásticas.

Mesmo assim, aponta que as manifestações mais importantes daquele momento não eram aquelas que conduziam à produção de um objeto - enquanto resultado materializado de um processo. Essa foi, inclusive, uma das recomendações da Mesa Redonda de 1969: que as bienais se adaptassem a esse deslocamento ocorrido nos anos anteriores.

Mario Schenberg apontava que para se compreender os problemas das bienais e da arte era preciso analisá-los a partir de um contexto mais amplo. A tecnologia, tomada como projeto histórico, como elemento formador de uma sociedade industrial, tinha por objetivo produzir objetos para serem vendidos, isto é, mercadorias. A arte também funcionou dentro desse movimento, tendo como finalidade a produção de obras de arte que, enquanto objetos, tornavam-se mercadoria.

Esse projeto histórico estaria chegando ao fim não por fracasso, mas por seu sucesso: a construção de uma sociedade industrial, com seus benefícios e problemas, já tinha se realizado. Contudo, Mario Schenberg tinha a convicção de que as possibilidades industriais não estavam sendo bem utilizadas. A tecnologia estaria sendo "usada caoticamente, sem um projeto social verdadeiramente determinado mas a jogo de interesses econômicos especiais", acusando "verdadeiramente uma crise profunda de valores da civilização ocidental" ${ }^{\text {365 }}$. As possibilidades apontadas pela indústria, que deveriam servir para melhorar a vida, não estariam sendo bem direcionadas. A poluição é trazida como exemplo de sua má utilização ${ }^{366}$.

No entender de Mario Schenberg, também na arte a tecnologia estava sendo mal utilizada. Mesmo reconhecendo que os novos materiais são úteis nas técnicas já existentes (novas tintas, pigmentos industrializados etc.), o crítico julga que sua presença, por si só, não "é sair tanto assim da arte tradicional" 367 . Pintar uma tela usando novas tintas, por exemplo, não seria tão inovador quanto utilizar diretamente a luz. Da mesma forma, realizar um desenho com a utilização de um computador se ele pudesse

\footnotetext{
${ }^{365}$ Mario Schenberg. Transcrição de sua intervenção na Mesa Redonda de 1971. Documento não datado, p. 3. Arquivo Histórico Wanda Svevo, Fundação Bienal.

${ }^{366}$ Essa linha de raciocínio será desenvolvida por Mario Schenberg ao longo da década de 1970, nos textos a respeito da Arte Ecológica e sobre a revisão da obra dos artistas do Grupo Santa Helena.

${ }^{367}$ Mario Schenberg. Transcrição de sua intervenção na Mesa Redonda de 1971. Documento não datado, p. 3. Arquivo Histórico Wanda Svevo, Fundação Bienal (foi mantida a grafia original do texto).
} 
ter sido feito à mão sem prejudicar sua proposta significava usar essa tecnologia sem necessidade.

Dito de outra forma, fazer com as novas tecnologias o que seria possível realizar antes delas e, principalmente, sem elas, significa deixar de aproveitar o verdadeiro potencial criativo aberto por elas. A tecnologia abria caminhos que iam além dos novos materiais: tornavam possível o que antes delas era irrealizável enquanto forma de expressão artística.

O crítico observa, ainda, que a civilização ocidental tinha na ciência e na tecnologia suas grandes realizações, mas carecia de uma visão ampla sobre seu verdadeiro significado e sobre sua real dimensão numa sociedade em crise. A supervalorização desses dois elementos poderia ser vista na tendência a idolatrar o computador, por exemplo, utilizando-o até mesmo quando não havia necessidade. Para ele, tanto a civilização ocidental quanto a arte se preocupam com o objeto em demasia.

Ao contrário da arte ocidental, a arte oriental não se preocupava com isso. Fazendo referência ao pensamento estético chinês e a Kandinsky ${ }^{368}$, Mario Schenberg observou que, quando a arte passa a ser entendida como processo de comunicação, o objeto passa a ter seu justo estatuto, porquanto deixa de ser o ponto central da arte. Desse modo, a obra detém apenas papel instrumental, em lugar de ser a finalidade da criação artística: "ser obra de arte não é característica de um objeto, é função que pode ter" 369.

A Arte Conceitual encontrava aí seu espaço de emergência, na medida em que vinha se tornando cada vez mais importante desde a segunda metade dos anos de 1960. "Realmente, a arte de nossa época é sobretudo uma arte de ideias" ${ }^{\text {"370 }}$. O crítico ressalta que o termo ideia, nesse caso, não deve ser tomado enquanto estrutura lógica, mas em sentido amplo, podendo ser "um valor, uma vivência, um sentimento do mundo ou outras coisas" 371 . Por isso, a Arte Conceitual seria a tendência que, pela primeira vez, estaria se aproximando do programa de Kandinsky, embora de forma mais racionalizada. A civilização ocidental, lembra o crítico, tende a exagerar na lógica.

\footnotetext{
368 Trata-se do livro Do Espiritual na Arte e na pintura em particular, do pintor Wassily Kandinsky. SCHENBERG, Mario. Diálogos com Mario Schenberg. São Paulo: Nova Sttela Editorial, 1985.

${ }^{369}$ Mario Schenberg. Transcrição de sua intervenção na Mesa Redonda de 1971. Documento não datado, p. 4. Arquivo Histórico Wanda Svevo, Fundação Bienal (foi mantida a grafia original do texto).

${ }^{370}$ Mario Schenberg. Transcrição de sua intervenção na Mesa Redonda de 1971. Documento não datado, p. 4. Arquivo Histórico Wanda Svevo, Fundação Bienal (foi mantida a grafia original do texto).

${ }^{371}$ Mario Schenberg. Transcrição de sua intervenção na Mesa Redonda de 1971. Documento não datado, p. 5. Arquivo Histórico Wanda Svevo, Fundação Bienal (foi mantida a grafia original do texto).
} 
Diante desse fato, já apontado na Mesa Redonda de 1969, Schenberg reiterou sua recomendação: se a Bienal não se adaptasse a essa nova realidade da arte, estaria fadada a desaparecer. Em seu entender, era necessário olhar para a arte a partir de um pensamento mais profundo, para compreender que a arte está condicionada ao seu momento histórico, e é por isso que tal questão estava relacionada com a crise das bienais $^{372}$.

O crítico apontou que, desde a segunda metade da década de 1960, deu-se uma mudança completa no caráter da arte e coisas que antes eram importantes deixaram de sê-lo. O foco da arte havia passado da elaboração de objetos para a busca de determinadas ideias, de determinados valores ${ }^{373}$. Daí viria a decadência das bienais, decorrente de seu apego à tradição do museu, querendo mostrar objetos, quando estes já não tinham mais tanta importância. Nesse sentido, as bienais não estavam apresentando a arte daquele momento, mas a de dez ou quinze anos antes. Para responder à realidade, era preciso compreender a transformação profunda da arte e realizar mudanças igualmente profundas na estrutura e organização das bienais. Segundo Schenberg, contudo, esse problema não era exclusividade da Bienal de São Paulo.

A participação do crítico é concluída com sua apreciação dos debates, porquanto afirma que os problemas acerca da relação entre a arte e a tecnologia haviam sido discutidos de modo "estreito, limitado e sobretudo unilateral" 374 . Cabe à arte desbravar caminhos para a criação de valores do futuro, na medida em que ela é capaz de responder ao desafio global lançado pela tecnologia aos nossos valores pós-renascentistas desgastados ${ }^{375}$.

\section{Afastamento da Bienal}

Importa destacar que a trajetória das bienais de São Paulo analisada neste trabalho foi marcada por crises, mas também por conquistas, na medida em que nelas havia lugar para o debate. Diversos aspectos dos eventos eram objeto de crítica, desde

\footnotetext{
${ }^{372}$ Mario Schenberg. Transcrição de sua intervenção na Mesa Redonda de 1971. Documento não datado. Arquivo Histórico Wanda Svevo, Fundação Bienal (foi mantida a grafia original do texto).

${ }^{373}$ Mario Schenberg. Transcrição de sua intervenção na Mesa Redonda de 1971. Documento não datado, p. 6. Arquivo Histórico Wanda Svevo, Fundação Bienal (foi mantida a grafia original do texto).

${ }^{374}$ Mario Schenberg. Transcrição de sua intervenção na Mesa Redonda de 1971. Documento não datado, p. 7. Arquivo Histórico Wanda Svevo, Fundação Bienal (foi mantida a grafia original do texto).

${ }^{375}$ Mario Schenberg. Transcrição de sua intervenção na Mesa Redonda de 1971. Documento não datado, p. 7. Arquivo Histórico Wanda Svevo, Fundação Bienal (foi mantida a grafia original do texto).
} 
o regulamento, passando pelo Júri de Seleção nacional, até o Júri de Premiação internacional. Cada escolha envolvia uma renúncia, o que naturalmente suscitava debates entre artistas, críticos e outros agentes do mundo das artes envolvidos no processo.

Apesar da crise instalada nas bienais no fim da década de 1960 ter sinalizado diversos pontos de vulnerabilidade no modus operandi da organização dos certames, ela não representou o fim da bienal. Além disso, é preciso ter em mente que essa não foi sua única crise e tampouco seria a última ${ }^{376}$.

Se por um lado as críticas traziam à tona impasses e destacavam problemas das Bienais, por outro evidenciavam a existência de um espaço em que havia a possibilidade de coexistência de diferentes visões e de inúmeros agrupamentos artísticos. Em outras palavras, se há discordância e discussão, é porque há espaço para que pessoas diferentes exteriorizem suas perspectivas. Num contexto de silenciamento e medo em que as liberdades individuais eram tolhidas em nome da repressão imposta pelo Regime Militar instaurado em 1964 - agravando-se com o Ato Institucional no 5 de 1968 (AI-5) -, o ambiente da Bienal, em que havia possibilidade de debate, era extremamente atrativo para artistas, críticos de arte e intelectuais.

Os impedimentos impostos a Mario Schenberg pelo Ato Complementar 75 pareciam indicar que o crítico não seria convidado para a Mesa Redonda pela Fundação Bienal. Por outro lado, se não lhe era possível uma atuação mais longa e remunerada, como era então a do corpo de jurados, não parecia haver entraves para sua participação pontual e voluntária no evento, uma vez que esse não tinha caráter acadêmico e estava fora de sua área na pesquisa científica. Essa era a hipótese inicial para explicar sua presença na mesa redonda da XI Bienal.

Ao longo desta pesquisa, novos elementos se somaram aos que haviam sido levantados na pesquisa anterior (PISMEL, 2013). À luz do aprofundamento da investigação, foi possível compreender que, embora Mario Schenberg não pudesse mais participar dos júris de seleção, não era intenção da Bienal deixar de contar com o crítico. Para o artista Caciporé Torres, por exemplo, dificilmente a Bienal teria ficado satisfeita ou aliviada com a restrição imposta a Mario Schenberg por conta do AI-5 e do AC-75, uma vez que reconhecia a relevância de sua contribuição nos certames anteriores

${ }^{376}$ Cf. AMARANTE, 1989 e ALAMBERT \& LOPES, 2004. 
(TORRES, 2018) $^{377}$. Por isso, acredita-se que uma vez que Schenberg ficava impedido de tomar parte até mesmo nesses eventos, Ciccillo Matarazo teria optado por resguardar tanto o próprio crítico, que estava sob vigilância contínua, quanto a própria Bienal, que perderia muito com os problemas que a presença de Schenberg implicaria após o AI-5.

Além disso, sabe-se que Mario Schenberg, por sua vez, tinha muito apreço por suas atividades nas bienais, e também pelo ambiente aberto ao debate que Ciccillo Matarrazzo foi capaz de promover nesse período. Afinal, os valores que o empresário trazia para o espaço dos certames iam ao encontro daqueles cultivados pelo crítico, que valorizava a abertura às novas ideias e ao debate. Tendo em vista esse conjunto de fatores, foi possível perceber não apenas que Schenberg deixou um espaço importante quando foi afastado da Bienal, mas também que, para Francisco Matarazzo Sobrinho, que tanto defendeu a presença do crítico no certame, o afastamento se deu apenas porque os novos mecanismos da repressão não deixaram escolha.

Sobre isso, Fábio Magalhães apontou que certamente Ciccillo teria ficado muito grato quando Mario Schenberg ficou ao lado da bienal no evento anterior, em 1969, dado que quase todos os artistas e toda a esquerda haviam ficado contra o certame: “(...) isso mostra que o Mario não tinha perdido esse olhar da arte como resistência, mas achava que era um absurdo as pessoas boicotarem um evento que era uma vitrine pra mostrar essa resistência” (MAGALHÃES, 2018) ${ }^{378}$. Para o curador, talvez Schenberg tenha tido outros motivos para se manter afastado das bienais ${ }^{379}$.

Também vai nesse sentido o depoimento da artista Maria Bonomi (2018), ao destacar a atmosfera de tensão e medo vigente entre o fim de 1968 e o início da década de 1970. Mario Schenberg, que já vinha sendo vigiado desde antes do golpe militar, era extremamente visado e, a partir daquele momento, também as pessoas com as quais ele convivia passaram a ser vigiadas. Visitar sua casa ou ter com o crítico passou a ser, de certo modo, perigoso. Para a artista, foi um período de "encolhimento", em que muitas

\footnotetext{
377 [Informação verbal]. TORRES, Caciporé. Entrevista concedida a Ana Paula Cattai Pismel. São Paulo, 8 mai. 2018. 1 arquivo .mp3 (16'39'). [A entrevista encontra-se depositada no Centro Mario Schenberg de Documentação da Pesquisa em Arte - ECA/USP].

378 [Informação verbal]. MAGALHÃES, Fábio. Entrevista concedida a Ana Paula Cattai Pismel. São Paulo, 5 abr. 2018. 12 arquivos .MOV (1h52'22'"). [A entrevista encontra-se depositada no Centro Mario Schenberg de Documentação da Pesquisa em Arte - ECA/USP].

379 "Eu acho que talvez esse afastamento tenha tido outras razões, talvez até pessoais. Não sei. O que eu sei é que o Mario, enquanto viveu, a casa dele sempre esteve cercada de artistas. Músicos também, escritores... O Mario era um homem da cultura, não era um homem segmentado das artes plásticas e da física". [Informação verbal] MAGALHÃES, Fábio. Entrevista concedida a Ana Paula Cattai Pismel. São Paulo, 5 abr. 2018. 12 arquivos .MOV (1h52'22'"). [A entrevista encontra-se depositada no Centro Mario Schenberg de Documentação da Pesquisa em Arte - ECA/USP].
} 
pessoas se viam obrigadas a se retirar, a fim de preservar aqueles que eram do seu convívio e poderiam ser prejudicados, caso fossem tomados como suspeitos de apoio à esquerda por parte do aparato de repressão ${ }^{380}$.

Fábio Magalhães ressalta que Mario Schenberg sofreu muito por causa da repressão, uma vez que o crítico era um "alvo aberto. Ele não era um clandestino. Primeiro, ele nunca aderiu à luta armada, mas sofreu as consequências, porque isso acirrou mais a repressão, e o Mario era um homem público, ele estava aí, ele nunca se exilou, nunca se escondeu" 381 . Sobre isso, o próprio crítico se manifestaria, em carta à escritora Clarice Lispector, já na década de 1970: “[d]esde 1970, minha situação geral se modificou bastante, em consequência do isolamento em que passei a viver, como resultado de minha aposentadoria compulsória e da impossibilidade de exercer a crítica de arte militante" ${ }^{382}$. O curador segue afirmando que o crítico só não foi mais prejudicado graças ao grande apoio internacional que sua figura era capaz de obter (MAGALHÃES, 2018) ${ }^{383}$. Curiosamente, a mesma projeção que, de certo modo, preservou o crítico, também o levava a ser extremamente vigiado (BONOMI, 2018) ${ }^{384}$.

É altamente provável que o próprio Mario Schenberg tenha optado por não colocar em risco as inúmeras pessoas com as quais ele teria contato publicamente, caso continuasse a exercer suas funções nas bienais. Com base no que foi possível aquilatar, pode-se supor que o crítico soubesse que seu afastamento das bienais fora motivado estritamente pela conjuntura política, dado o respeito mútuo que havia entre ele e Ciccillo Matarazzo. Talvez isso possa explicar o motivo pelo qual o crítico não tenha

\footnotetext{
380 [Informação verbal] BOMONI, Maria. Entrevista concedida a Ana Paula Cattai Pismel. São Paulo, 16 mai. 2018. 4 arquivos .mp3 (1h46'15'). [A entrevista encontra-se depositada no Centro Mario Schenberg de Documentação da Pesquisa em Arte - ECA/USP].

${ }^{381}$ [Informação verbal] MAGALHÃES, Fábio. Entrevista concedida a Ana Paula Cattai Pismel. São Paulo, 5 abr. 2018. 12 arquivos .MOV (1h52'22'"). [A entrevista encontra-se depositada no Centro Mario Schenberg de Documentação da Pesquisa em Arte - ECA/USP].

${ }^{382}$ Carta enviada por Mario Schenberg a Clarice Lispector. Arquivo Histórico do Instituto de Física da USP. Cf. HAMBURGUER, Amélia Império. Breve biografia acadêmica. In HAMBURGUER, Amélia Império et al. Obra Científica de Mario Schenberg. Volume 1. São Paulo: EDUSP, 2009.

383 [Informação verbal] MAGALHÃES, Fábio. Entrevista concedida a Ana Paula Cattai Pismel. São Paulo, 5 abr. 2018. 12 arquivos .MOV (1h52'22'"). [A entrevista encontra-se depositada no Centro Mario Schenberg de Documentação da Pesquisa em Arte - ECA/USP].

384 “[ [...] você começa a estar com Mario Schenberg, você frequenta Mario Schenberg, vai à casa do Mario Schenberg... Ele era acompanhado, ele era vigiado, entende? Tanto assim, que às vezes eu fui na casa dele levar uns trabalhos ou alguma coisa e lembro que o pessoal dizia 'Ah, vê lá. É perigoso você ir lá, ele pode ser preso'.” [Informação verbal] BOMONI, Maria. Entrevista concedida a Ana Paula Cattai Pismel. São Paulo, 16 mai. 2018. 4 arquivos .mp3 (1h46'15'). [A entrevista encontra-se depositada no Centro Mario Schenberg de Documentação da Pesquisa em Arte - ECA/USP]. Cf., ainda, BONOMI, Maria. Depoimento Maria Bonomi. In Revista da Biblioteca Mário de Andrade. O Medo. São Paulo, $\mathrm{n}^{\circ}$ 70, 2016, pp. 148-163. Nesse depoimento estão registradas as dificuldades do período da ditadura, bem como o relato acerca da prisão da artista e da atmosfera de medo em que se vivia então.
} 
externado publicamente um eventual descontentamento com a bienal, como o fez acerca da conjuntura política.

Diante do exposto acima, cabe esclarecer que a hipótese inicial deste estudo foi parcialmente modificada, porquanto é improvável que o afastamento de Mario Schenberg tenha se dado por iniciativa da própria Bienal. Contudo, não foram encontrados elementos que dessem conta de responder a essa questão com maior precisão. Isso porque as fontes analisadas forneceram indicações que, apesar de valiosas, permanecem no campo da probabilidade.

Já a parcela da hipótese que creditava o afastamento do crítico do Júri de Seleção ao recrudescimento da repressão por meio de mecanismos como o AI-5 e o AC-75 se fortaleceu e agora figura como a única linha de investigação para estudos futuros. Se antes acreditava-se que a Bienal teria visto tais impedimentos como uma oportunidade para fazer com que o crítico ficasse fora do evento, agora sabe-se que o mais provável é que os próprios artistas tenham optado por resguardar a figura de Schenberg. A Bienal,

Figura 54 - Abertura da $11^{\text {a }}$ Bienal com as presenças de Jarbas Passarinho, Laudo Natel, Francisco Matarazzo Sobrinho e Roberto Costa de Abreu Sodré. Autor não identificado.

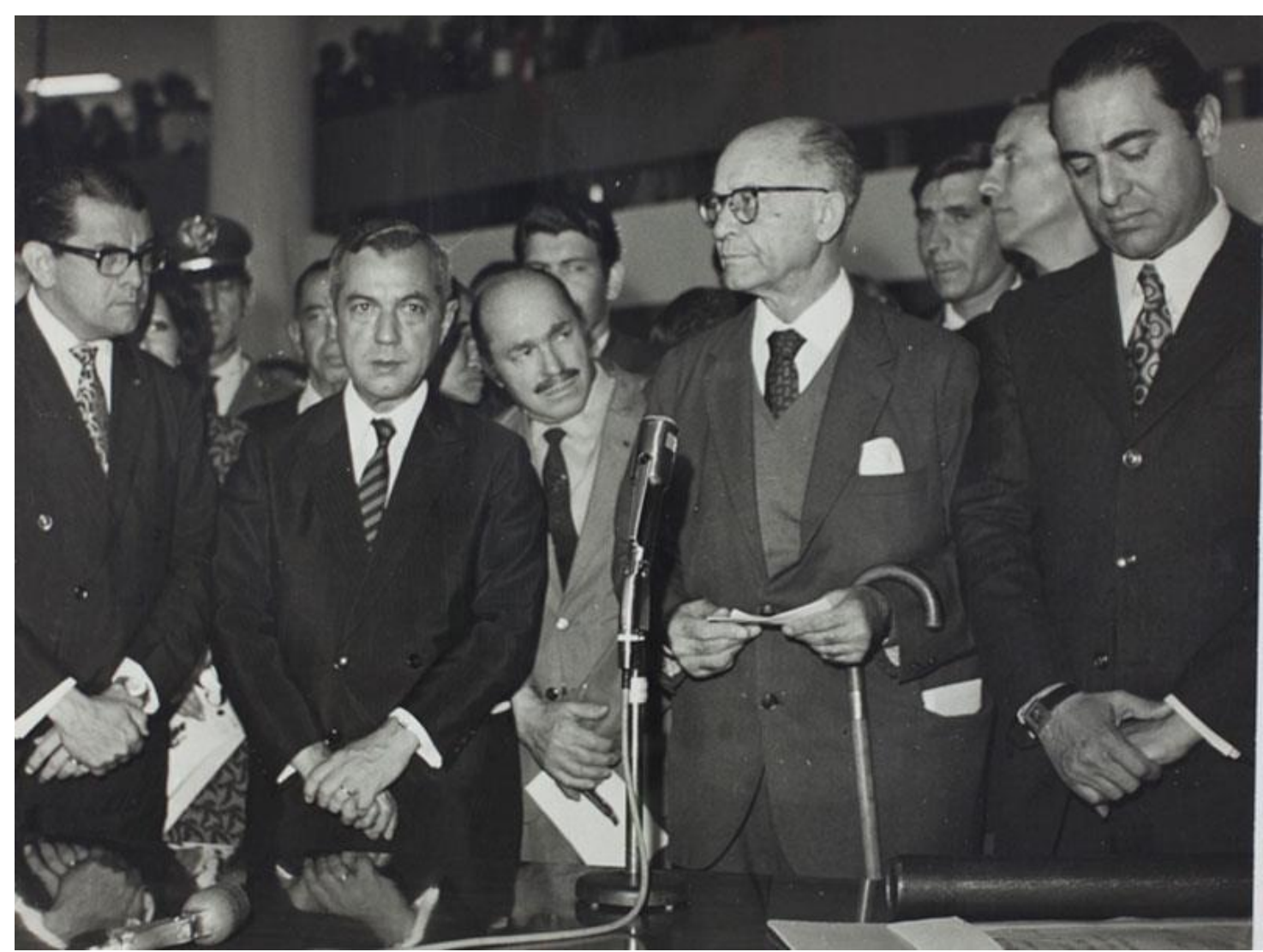

Fonte: FUNDAÇÃO BIENAL DE SÃO PAULO. 11ª Bienal de São Paulo. Disponível em: http://www.bienal.org.br/exposicoes/11bienal/fotos/3904 Acesso em: 12/06/2018. 
que não poderia mais absorver o crítico em seus quadros, teria seguido o mesmo caminho de modo estratégico para evitar indisposições com o regime militar num contexto tão delicado.

Bienais de Ciência e Humanismo (1967, 1969 e 1971): ausência notável

Se na Mesa Redonda de Críticos de Arte foi a presença improvável de Mario Schenberg que chamou a atenção, nas bienais de Ciência e Humanismo foi a ausência de um dos mais eminentes cientistas do país que se mostrou eloquente. Essa segmentação das bienais teve início em 1967, paralelamente à IX Bienal de Arte de São Paulo, projetada sob a forma de um Simpósio Mundial de Integração CiênciaHumanismo, do qual participaram cientistas do Brasil e do exterior. Os países participantes, entre eles Estados Unidos, França, Inglaterra, Israel e Alemanha, trouxeram exposições de divulgação tecnológica para integrar o evento.

Segundo Ciccillo Matarazzo, a finalidade da I Bienal de Ciência e Humanismo era "atrair para o nosso País a discussão dos temas científicos mais importantes da atualidade" 385 . A idealização do certame teve em vista a integração entre as Artes e as Ciências, e foi a primeira do gênero na América Latina, gerando muita repercussão na época.

Os seminários internacionais trataram dos seguintes temas: 1) Ciências e humanidades: semelhanças e contrastes; 2) Influência recíproca das ciências e do humanismo na atualidade; 3) Difusão recíproca de conceitos humanísticos e científicos e 4) Divulgação do conhecimento científico e humanístico. Ao público não especializado estavam destinadas as exposições científicas, cuja finalidade era evidenciar o impacto do conhecimento científico na vida diária ${ }^{386}$.

A II Bienal de Ciência e Humanismo, em 1969, contou com três simpósios internacionais e um seminário nacional. Este girou em torno do livro e da comunicação de massa, enquanto aqueles abordaram os seguintes temas: "transplantes de órgãos vitais", "investigação clínica a respeito das úlceras de estômago e duodeno" e "aspectos 
Figura 55 - X Bienal de São Paulo, em 1969. Em primeiro plano, estruturas temporárias, em forma de oca, construídas para abrigar os eventos da II Bienal de Ciência e Humanismo.

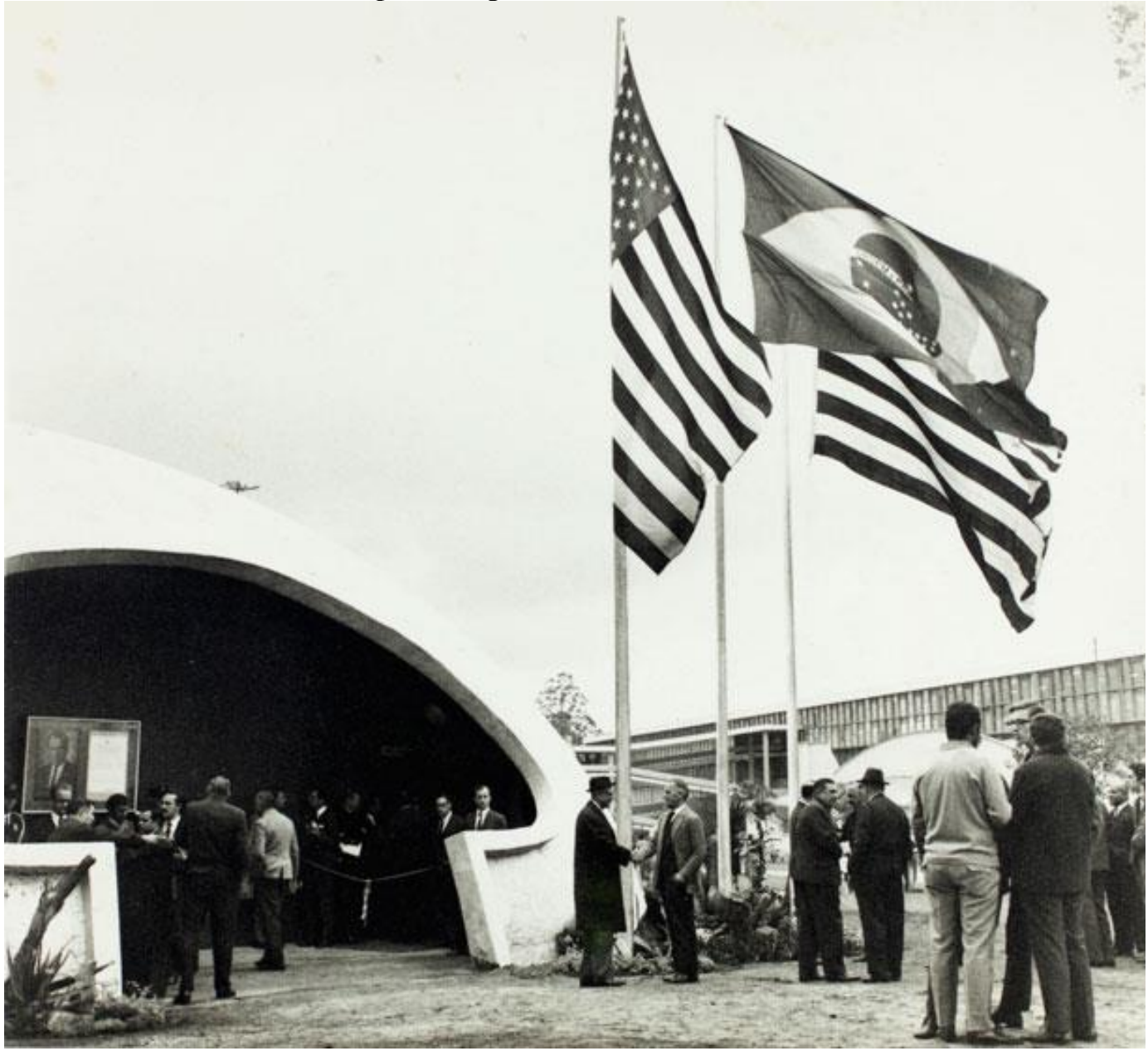

Fonte: Arquivo Histórico Wanda Svevo/Fundação Bienal.

humanísticos da ciência", que propunha um diálogo entre artistas, escritores e filósofos ${ }^{387}$. Entre os subtemas desse segundo simpósio estavam "a criatividade na ciência e nas artes" e a "humanização da ciência", temas muito caros a Mario Schenberg.

Aconteceu também a exposição "Átomos em Ação”, organizada pela Comissão de Energia Atômica dos Estados Unidos. Três edifícios foram construídos ao lado do pavilhão da Bienal para abrigá-la ${ }^{388}$. Essa ramificação da Bienal passou a ter seu regulamento incluído no catálogo da exposição ${ }^{389}$.

Por ocasião da III Bienal de Ciências e Humanismo, em 1971, foi criado um prêmio para a descoberta científica mais relevante, concedido ao pesquisador que

\footnotetext{
387 Cientistas e humanistas na Bienal de Ciências. Folha de São Paulo, 11 abr. 1969.

${ }^{388}$ Ciência \& Arte: X Bienal de São Paulo. Diário Popular, 19 out. 1969.

${ }^{389}$ FUNDAÇÃO BIENAL. X Bienal. (catálogo de exposição) São Paulo: Fundação Bienal, 1969, p. 44 e 443.
} 
desenvolveu a produção artificial de insulina, descoberta que beneficiou portadores de diabetes $^{390}$. Foi realizado um simpósio internacional do qual participaram 26 convidados estrangeiros, incluindo o premiado ${ }^{391}$. Além disso, foram publicados os Anais do Simpósio sôbre Ciência e Humanismo (grafia original), que contou com textos e resumos das conferências apresentadas na edição anterior ${ }^{392}$.

Ao longo das três edições que aconteceram dentro do período analisado, críticos de arte (como Vilém Flusser) e físicos brasileiros da Universidade de São Paulo (como José Goldenberg) tiveram voz nas bienais de Ciência e Humanismo. Diante disso, cabe a seguinte questão: por que Mario Schenberg, físico teórico de carreira internacional e crítico de arte, que tinha tanto a contribuir nas discussões promovidas e, além de tudo, esteve envolvido na organização das bienais de Artes Plásticas por toda a década de 1960, não tomou parte no evento, seja em sua organização, seja como conferencista?

É altamente provável que esse afastamento tenha ocorrido em decorrência do AI-5 e do Ato Complementar 75, que proibiam Mario Schenberg de atuar "como professor, funcionário ou empregado de estabelecimento de ensino público", bem como de "exercer, a qualquer título, cargo, função, emprego ou atividades, em estabelecimentos de ensino e em fundações criadas ou subvencionadas pelos Poderes Públicos"393. Se não lhe era possível circular em campi universitários, nem utilizar suas bibliotecas, é plausível supor que também não fosse possível ao cientista tomar parte nas bienais de Ciência e Humanismo. Isso porque esses eventos, além de serem promovidos por uma Fundação que recebia recursos municipais e estaduais, se configuravam como eventos científicos.

Há no Arquivo Histórico Wanda Svevo muita documentação a respeito da organização desses eventos que não foi completamente estudada na pesquisa de mestrado pelos seguintes motivos: primeiro, porque esse aspecto das bienais não fazia parte do recorte delimitado; segundo, por falta de tempo. Na primeira análise não foram

\footnotetext{
${ }^{390}$ FUNDAÇÃO BIENAL. XI Bienal. (catálogo de exposição) São Paulo: Fundação Bienal, 1971, p. 256-57.

391 "Relatório das Atividades em 1971". Documento datilografado, datado de janeiro de 1972. Arquivo Histórico Wanda Svevo, Fundação Bienal.

${ }^{392}$ FUNDAÇÃO BIENAL DE SÃO PAULO. Anais do Simpósio sôbre Ciência e Humanismo. São Paulo: out. 1971. Foi mantida a grafia da época.

${ }^{393}$ ATO Complementar $\mathbf{n}^{\mathbf{0}} \mathbf{7 5}$, de 21 de outubro de 1969, Diário Oficial da União, p. 8930. Disponível em: 〈http://www.planalto.gov.br/ccivil 03/ACP/acp-75-69.htm>. Acesso em: 20 fev. 2013. Esse Ato Complementar foi assinado por Luiz Antônio da Gama e Silva, que foi reitor da Universidade de São Paulo, tendo assinado também o AI-5, e por Antônio Delfim Neto, docente da Faculdade de Economia e Administração da USP. Agradeço ao Prof. Dr. Francisco Alambert pelo auxílio e pelas conversas a respeito do aspecto social e político desse período.
} 
encontrados indícios de que Mario Schenberg tivesse tomado parte na organização dessas bienais, nem como convidado. Com isso, a dúvida a respeito da ausência do eminente físico teórico de renome internacional surgiu com eloquência nas bienais de Ciência e Humanismo, dada a proximidade física e intelectual dos eventos.

Mesmo em uma segunda análise da documentação relativa ao evento, efetuada após o trabalho de aperfeiçoamento da organização do material depositado no Arquivo Histórico Wanda Svevo e do aprofundamento da investigação em nível de doutorado, não foi possível esclarecer a dúvida acerca do motivo pelo qual Mario Schenberg não tomou parte do evento. Contudo, pôde-se refinar a hipótese anteriormente levantada.

Nesse momento, tornou-se possível estudar praticamente toda a documentação relativa às bienais de Ciência e Humanismo, o que permitiu encontrar apenas duas ocorrências do nome do físico em todo o conjunto analisado. A primeira delas foi a menção a Mario Schenberg encontrada entre as cópias das cartas de agradecimento enviadas a diversas autoridades que estiveram presentes no evento em 19 de dezembro de $1967^{394}$. Isso é de extrema relevância, pois indica que o cientista não apenas assistiu às conferências - ainda que da plateia -, como sua presença recebeu destaque pela organização do evento, que agradeceu a ele do mesmo modo que o fez às demais autoridades que haviam comparecido ${ }^{395}$.

A segunda foi identificada numa proposta de parte da programação para o segundo evento, datada de 23 de abril de $1968^{396}$. A proposta foi elaborada pelos membros da Comissão Organizadora, formada por José Goldemberg, Lauro Nepomuceno, Sérgio Mascarenhas e Amélia Império Hamburguer, sendo que foram consultados outros Professores da Comissão, como Oscar Sala, José Leite Lopes e Erasmo M. Ferreira. Segundo o que foi proposto, Mario Schenberg integraria a sessão de Física Teórica, falando sobre o tema "Relatividade". Entre esses nomes, podemos destacar Amélia Império Hamburguer e José Leite Lopes, que estiveram próximos de Mario Schenberg na Universidade de São Paulo ${ }^{397}$. Outra observação a ser feita é que

\footnotetext{
${ }^{394}$ Carta de Luís Fernando Rodrigues Alves (Diretor Secretário) a Mario Schenberg, datada de 19 de dezembro de 1967. Arquivo Histórico Wanda Svevo/Fundação Bienal.

395 José Leite Lopes e José Goldemberg, que também faziam parte do Departamento de Física da então Faculdade de Filosofia, Ciências e Letras da USP e eram próximos de Mario Schenberg, figuravam entre os destinatários das cartas de agradecimento. Entre eles estava, ainda, o artista Waldemar Cordeiro e o crítico Vilém Flusser. Arquivo Histórico Wanda Svevo/Fundação Bienal.

396 "Proposta para a Bienal de Física de 1969 da Bienal de Ciência e Humanismo". Documento datilografado, datado de 23 de abril de 1968. Arquivo Histórico Wanda Svevo/Fundação Bienal.

${ }^{397}$ Cf. HAMBURGUER, Amélia Império et al. Obra Científica de Mario Schönberg. Volume 1. São Paulo: EDUSP, 2009. Mario Schenberg usava o sobrenome Shönberg em suas publicações científicas.
} 
quando a proposta foi elaborada e enviada à Fundação Bienal, em abril de 1968, o Ato Institucional $\mathrm{n}^{\circ} 5$ ainda não era uma realidade, tendo sido baixado apenas em 13 de dezembro do mesmo ano. Portanto, não havia impedimentos à participação de Schenberg naquele momento.

Salvo o referido documento, não houve qualquer outra menção ao nome do cientista na documentação relativa aos trâmites de organização do certame. Isso mostra que, pelo menos inicialmente, cogitou-se convidá-lo para dar uma palestra. Contudo, não havia nenhum registro posterior que desse conta do motivo pelo qual seu nome fora retirado de pauta e do evento ${ }^{398}$.

Apesar de acrescentar alguns elementos novos à investigação realizada, ainda não se pode explicar o motivo da ausência de Mario Schenberg das Bienais de Ciência e Humanismo. Pôde-se, contudo, refinar a hipótese anterior com base no que foi apurado e, também, nas entrevistas realizadas. Ainda que nenhum dos entrevistados tivesse recordação das Bienais de Ciência e Humanismo, as informações por eles fornecidas dão conta de que, tendo em vista o profundo respeito que havia entre Ciccillo Matarazo e Mario Schenberg, dificilmente o cientista teria sido excluído do evento pela Fundação Bienal $^{399}$. Sabe-se que Schenberg, ao atuar nas bienais de São Paulo, também trazia para elas sua projeção como figura internacional no campo da ciência. Esse fato, somado à estima e respeito de Ciccilo por sua erudição, bem como por seu trabalho como crítico de arte (BONOMI, 2018), torna possível supor que a ausência de Mario Schenberg das bienais de Ciência e Humanismo estaria ligada a uma tentativa de resguardar tanto o crítico quanto a própria Bienal, uma vez que o AI-5 era uma ferramenta recente da repressão ao extrato intelectual por parte do regime militar, cujo propósito era justamente impedir que os professores atingidos pela perseguição política reassumissem seus cargos, como havia ocorrido em 1964 (MOTTA, 2014).

No caso desta pesquisa, apesar de ter avançado em relação à investigação anterior (PISMEL, 2013), refinando as hipóteses nela formuladas, considera-se que

\footnotetext{
${ }^{398}$ Cf. "Ata da reunião preparatória da II Bienal de Ciência e Humanismo". Documento datilografado, datado de 4 de fevereiro de 1969. Arquivo Histórico Wanda Svevo/Fundação Bienal; e "Ata da primeira reunião da Comissão Coordenadora da II Bienal de Ciência e Humanismo". Documento datilografado, datado de 13 de fevereiro de 1969. Arquivo Histórico Wanda Svevo/Fundação Bienal. A ata da primeira reunião, já posterior ao Ato Institucional $\mathrm{n}^{\circ} 5$, traz apenas a informação de que foram feitas "pequenas modificações nos nomes sugeridos", sem dar as razões das mudanças. Após essa sinalização, o nome de Mario Schenberg deixou de figurar na elaboração da programação do evento.

${ }^{399}$ Informação verbal fornecida por Silvio Salinas em 7 mai. 2018, no Instituto de Física da USP. Cf. também SCHENBERG, 2018; BOMONI, 2018; TORRES, 2018; AGUILAR, 2018 e MAGALHÃES, 2018.
} 
caberá à continuidade dos estudos acerca das Bienais de Ciência e Humanismo elucidar de modo mais amplo diversos aspectos desses eventos. Afinal, até o momento, não foram feitos estudos específicos a respeito desses certames, cuja documentação está inteiramente disponível no Arquivo Histórico Wanda Svevo, na Fundação Bienal ${ }^{400}$.

${ }^{400}$ Constatou-se que, salvo algumas poucas referências que tangenciam o evento, quase sempre quando um pesquisador trata de algum dos nomes que dele participaram, não há estudos específicos sobre as Bienais de Ciência e Humanismo. Em vista disso, esse é um campo a ser explorado por estudos futuros. 
Figura 56 - José Leite Lopes e Mario Schenberg no Instituto de Física da USP, s/d.

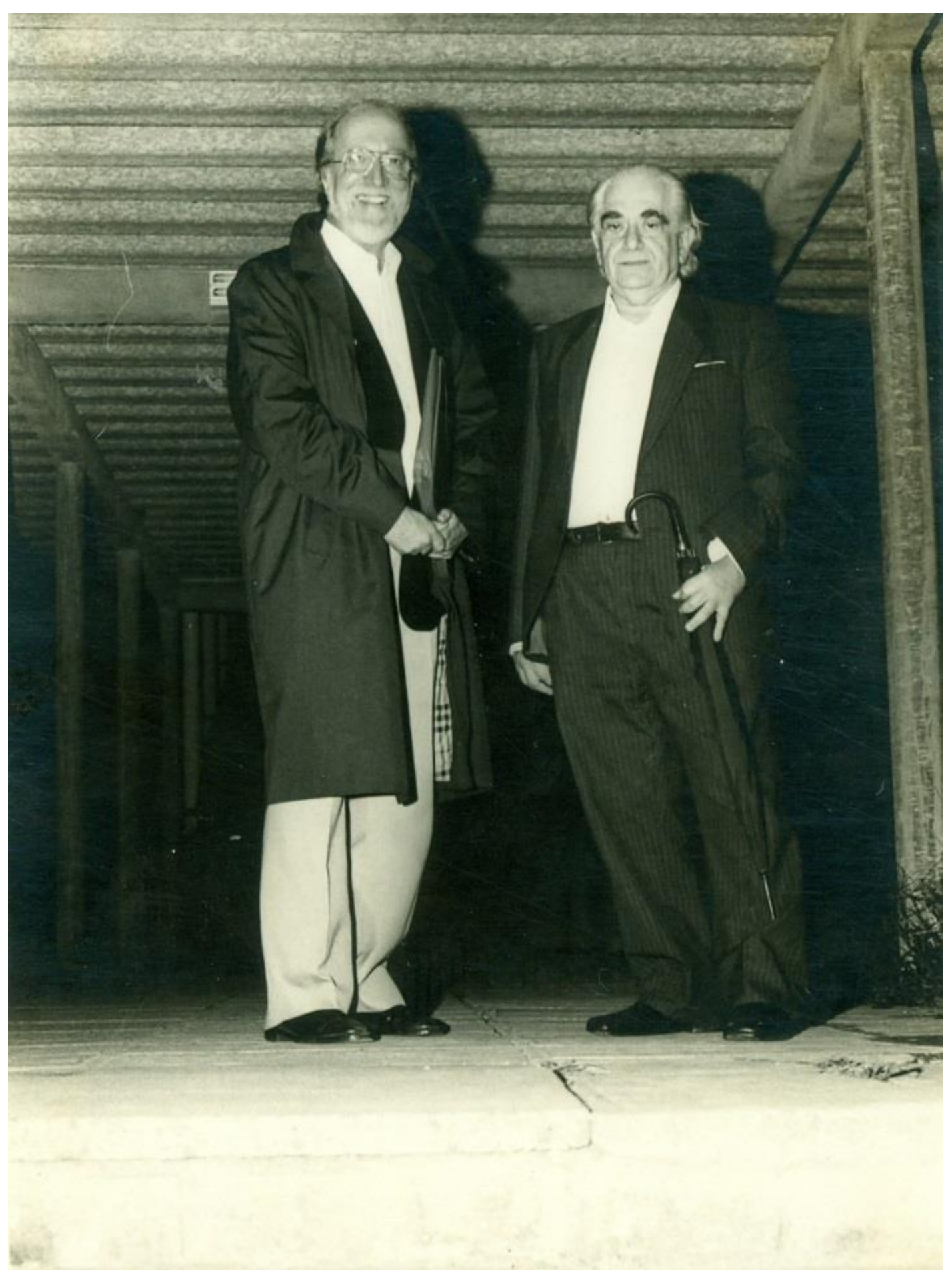

Fonte: Acervo Histórico do Instituto de Física. 
Tudo o que é realmente grande e inspirador é criado pelo indivíduo que pode trabalhar em liberdade. ${ }^{401}$

Albert Einstein

Fomento à Pesquisa na Ciência e na Arte

Tendo em vista a intervenção de Schenberg na Mesa Redonda Internacional de Críticos de Arte da AICA (1969), que defendia a criação de condições para o desenvolvimento da pesquisa artística, sobretudo por meio da concessão de bolsas e da criação de fundos de fomento ${ }^{402}$, não é difícil identificar a aproximação entre o que o crítico colocava em debate e o que o cientista já defendia no meio acadêmico. Note-se que na década de 1940, o Professor Schenberg, então suplente de deputado estadual na Assembleia Constituinte pelo $\mathrm{PCB}^{403}$, teve um papel importante na criação da lei que, anos depois, daria origem à Fundação de Amparo à Pesquisa do Estado de São Paulo (FAPESP). Luiz Hildebrando Pereira da Silva relata que Schenberg esteve presente tanto na etapa de criação como na de implantação da FAPESP ${ }^{404}$.

No ano de 1947, um grupo organizado de pesquisadores e professores universitários, encabeçados por Adriano Marchini e João Luiz Meiller, apresentou um documento por meio do qual pretendia sensibilizar os deputados da Assembleia Constituinte de 1947 para criarem uma fundação que impulsionasse o avanço da ciência

401 EINSTEIN, Albert. Pensamento político e ultimas conclusões. Seleção e prefácio de Mario Schenberg. São Paulo: Brasiliense, 1983, p. 29.

${ }^{402}$ Recomendações da Mesa Redonda de críticos de arte internacionais. Documento não datado, com duas páginas. Arquivo Histórico Wanda Svevo, Fundação Bienal.

${ }^{403}$ KINHSHITA, Dina Lida. Mario Schenberg: o cientista e o político. Brasília: Fundação Astrogildo Pereira, 2014.

404 "Na verdade, um outro setor muito importante da atividade política do Partido e do Schenberg nesse movimento cultural-científico foi a implantação real, concreta, da FAPESP. De certo modo pode-se considerar a FAPESP como uma obra do Partido nas suas duas etapas. Na etapa da sua criação, em que o Caio Prado e o Schenberg, na bancada do Partido na Constituinte paulista, foram os elementos que permitiram incluir na Constituição do Estado as regras, o princípio constitucional que foi a garantia da criação da FAPESP, e na segunda etapa, a da criação efetiva da FAPESP, que foi o resultado de uma pressão de base feita desde o período antecedendo o governo Garcez e depois no governo do Carvalho Pinto". Cf. SILVA, Luiz Hildebrando Pereira da. Depoimento. In MAMBURGUER, Amélia Império et al (organização e edição). FAPESP 40 anos: abrindo fronteiras. São Paulo: Editora da Universidade de São Paulo, 2005, p. 530. 
e da tecnologia no estado de São Paulo. Esse documento, intitulado "Ciência e Pesquisa - Contribuição de Homens do Laboratório e da Cátedra à Magna Assembleia Constituinte de São Paulo", foi submetido e deu origem ao artigo 123 da Constituição paulista $^{405}$.

$\mathrm{O}$ artigo 123 previa o apoio à pesquisa cientifica, a ser prestado por uma fundação nos moldes do que viria a ser a atual FAPESP. Veja-se o artigo:

Artigo 123 - O amparo à pesquisa científica será propiciado pelo Estado, por intermédio de uma Fundação, organizada em moldes que forem estabelecidos por lei.

Parágrafo único - Anualmente, o Estado atribuirá a essa Fundação, como renda de sua privativa administração, quantia não inferior a meio por cento do total de sua receita ordinária ${ }^{406}$.

Muitos deputados deram apoio à petição. Entre eles, podemos citar nomes como Ulysses Guimarães, Lincoln Feliciano, Aloysio Nunes Ferreira, entre outros. Mario Schenberg, enquanto cientista e suplente de deputado estadual, foi uma figura central na elaboração do projeto $^{407}$. Em 2 de outubro de 1947, a bancada do PCB, liderada pelo deputado Caio Prado Jr., apresentou o Projeto de Lei 248/47, que regulamentaria a criação de Fundação Paulista de Pesquisas Científicas ${ }^{408}$.

Quando da apresentação do projeto, o deputado Caio Prado Jr. apontou a necessidade de regulamentação do artigo 123, a fim de que, já no ano seguinte, fossem iniciados os trabalhos de implementação das atividades de fomento à pesquisa científica. Em discurso proferido por ele na sessão plenária de 2 de outubro de 1947, disse:

Inserido esse princípio em nossa Constituição, é de todo interesse e toda necessidade que, quanto antes, entre em vigor, e que seja regulamentado para que, desde logo, as pesquisas científicas e os pesquisadores de São Paulo e do Brasil possam prevalecer-se desse grande auxílio que a Constituição do Estado pôs à sua disposição.

$[\ldots]$

${ }^{405}$ FAPESP. Linha do Tempo. Disponível em: <http://www.bv.fapesp.br/linha-do-tempo/212/artigo123-constituicao-1947/>. Acesso em: 28 fev. 2017.

${ }^{406}$ ASSEMBLEIA LEGISTATIVA DO ESTADO DE SÃO PAULO. Constituição de 1947. Disponível em: 〈http://www.al.sp.gov.br/leis/constituicoes/constituicoes-anteriores/constituicao-estadual-1947/>. Acesso em: 28 fev. 2017.

${ }^{407}$ KINHSHITA, Dina Lida. Mario Schenberg: o cientista e o político. Brasília: Fundação Astrogildo Pereira, 2014.

${ }^{408}$ PROJETO DE LEI n ${ }^{\circ} 248$ de 1947. Institui a Fundação Paulista de Pesquisas Científicas. In: MOTOYAMA, S.; Hamburger, A.I.; NAGAMINI, M. (Orgs.) Para uma história da FAPESP: marcos documentais. São Paulo: FAPESP, 1999. p. 69-73. 
O princípio fundamental que rege esse projeto de lei criando o Instituto de Pesquisas Científicas é o da mais ampla autonomia, evitando assim a interferência da ordem política ou outras que possam desviar a fundação de seus objetivos, permitindo-lhe realizar o grande programa que terá à sua frente ${ }^{409}$.

Apesar do esforço no sentido de dar prosseguimento à criação desse órgão de fomento à pesquisa, foi somente em 1960 que se deu a formalização da Fundação Paulista de Pesquisas Científicas. Após a mobilização de mil pesquisadores e professores da Universidade de São Paulo, que assinaram um memorial pedindo agilidade na tramitação do Projeto de Lei 1.953 (após diversas idas e vindas de negociação), o governador Carlos Alberto de Carvalho Pinto promulgou, em 18 de outubro de 1960, a Lei Orgânica n. 5918, autorizando o Poder Executivo a instituir a Fundação de Amparo à Pesquisa do Estado de São Paulo ${ }^{410}$.

Um ponto a ser destacado, de extrema importância para o Professor Schenberg e que aparece no discurso de Caio Prado Jr., é a necessidade de autonomia nas pesquisas. A existência de um órgão de fomento que atue de modo autônomo e financie a pesquisa científica no estado de São Paulo, que já tinha na época diversas instituições que realizavam pesquisas em diferentes áreas do conhecimento ${ }^{411}$, poderia garantir a realização de investigações que, de outro modo, não encontrariam financiamento.

Em outras palavras: uma fonte de financiamento que tivesse autonomia em relação a pressões e direcionamentos de instâncias externas, como já se via em diversos outros países ${ }^{412}$, permitiria aos pesquisadores terem liberdade para trabalhar. Para Mario Schenberg, esse era um ponto relevante quando se tratava de lançar as bases do desenvolvimento científico no país ${ }^{413}$.

409 DOCUMENTO 4: Discurso do Deputado Caio Prado Jr. na sessão do dia 2 de outubro. In: MOTOYAMA, S.; Hamburger, A.I.; NAGAMINI, M. (Orgs.) Para uma história da FAPESP: marcos documentais. São Paulo: FAPESP, 1999. p. 66.

${ }^{410}$ FAPESP. Linha do tempo. Disponível em: <http://www.bv.fapesp.br/linha-do-tempo/249/carvalhopinto-aprova-criacao-fapesp/ $>$. Acesso em 28 fev. 2017. Ver também: ASSEMBLÉIA LEGISTATIVA DO ESTADO DE SÃO PAULO. LEI N. 5.918, DE 18 DE OUTUBRO DE 1960. Disponível em: $<$ http://www.al.sp.gov.br/repositorio/legislacao/lei/1960/lei-5918-18.10.1960.html〉. Acesso em: 28 fev. 2017.

${ }^{411}$ KINHSHITA, Dina Lida. Mario Schenberg: o cientista e o político. Brasília: Fundação Astrogildo Pereira, 2014.

${ }^{412}$ KINHSHITA, Dina Lida. Mario Schenberg: o cientista e o político. Brasília: Fundação Astrogildo Pereira, 2014.

${ }^{413}$ SCHENBERG, Mario. Formação da Mentalidade Científica. In Estudos Avançados, 12(5), 1991, pp. 123-151. 
Tendo acompanhado o desenvolvimento da Universidade de São Paulo desde a sua criação, quando era aluno da Escola Politécnica ${ }^{414}$, Schenberg criticava a reforma universitária de 1968, que aumentava a burocracia acadêmica e cobrava maior produtividade dos pesquisadores ${ }^{415}$. O cientista acreditava que o importante não era desperdiçar os melhores anos dos jovens pesquisadores com a realização de longos cursos de pós-graduação e teses, mas promover a liberdade para que eles tivessem boas ideias ${ }^{416}$. Sobre isso, o cientista afirmaria mais tarde, em 1982: "É lamentável o que está acontecendo no Brasil em relação à criação: prende-se o jovem até depois dos 30 anos, desperdiçando-se sua vitalidade. É necessário estudar uma maneira de melhorar essa situação" ${ }^{417}$.

Schenberg argumenta que, com menos burocracia e mais liberdade de pensamento, surgiriam mais ideias novas, muitas delas originais. Isso, sem dúvida, contribuiria para o avanço da ciência de forma mais eficiente do que a profusão de publicações realizadas tendo em vista somente a exigência de produtividade ${ }^{418}$.

O caminho apontado pelo cientista para o avanço da ciência no Brasil tinha uma direção distinta da que vigorava na cultura universitária instaurada pela reforma. Para entender melhor esse ponto, é preciso tem em mente que, no campo da história da ciência, começavam a ser feitas revisões que o Professor Schenberg considerava importantes. Autores como Henri Poincaré e Albert Einstein apontavam que a lógica e a razão eram, sem dúvida, importantes na demonstração e na operacionalização das descobertas cientificas, mas a intuição e a imaginação é que permitiam criar. Tendo em vista essas referências, Schenberg desenvolveu sua concepção a respeito da importância da intuição como elemento criativo tanto na ciência quanto na arte ${ }^{419}$.

\footnotetext{
${ }^{414}$ HAMBURGUER, Amélia Império. Nota biográfica e entrevista com Mario Schenberg (Novembro, 1983). São Paulo: Instituto de Física, Universidade de São Paulo, 1984.

${ }^{415}$ SCHENBERG, Mario. Formação da Mentalidade Científica. In Estudos Avançados, 12(5), 1991, pp. 123-151.

${ }^{416}$ SCHENBERG, Mario. Formação da Mentalidade Científica. In Estudos Avançados, 12(5), 1991, pp. 123-151.

${ }^{417}$ SCHENBERG, Mario. Formação da Mentalidade Científica. In Estudos Avançados, 12(5), 1991, p. 141. "Eu acho profundamente negativo que o jovem fique perdendo anos, anos e anos fazendo cursos. Ele deve o mais rapidamente possível, mesmo desde o tempo de estudante se ele tem jeito, ser encaminhado para a pesquisa. Depois fará ou não fará os cursos. Com essa ossificação burocrática, cada vez o sujeito vai adiando para depois e a maioria acaba não fazendo nada. A pessoa faz a tal tese de mestrado, a tese de doutorado e depois encerra a sua atividade científica e também a sua época de maior energia.” SCHENBERG, Mário. Mário Schenberg (depoimento, 1978). Rio de Janeiro, CPDOC, 2010, p. 92.

${ }^{418}$ SCHENBERG, Mario. Formação da Mentalidade Científica. In Estudos Avançados, 12(5), 1991, pp. 123-151.

${ }^{419}$ Cf. POINCARÉ, Henri. Valor da ciência. Rio de Janeiro: Contraponto, 1995; POINCARÉ, Henri. Science et méthode. Paris: Flammarion, 1947; EINSTEIN, Albert. Pensamento político e últimas
} 
Mesmo no meio artístico, o prestígio do Professor Schenberg como cientista de renome internacional contribuiu para sedimentar a credibilidade de sua crítica de arte, na medida em que sua posição acadêmica inspirava respeito. Escrevendo sobre os artistas que incentivava, o crítico utilizava sua posição social e intelectual para dar visibilidade ao trabalho deles ${ }^{420}$.

Essa atitude do crítico mostrou-se importante em relação a uma das características da arte de vanguarda das décadas de 1960 e 1970: a emergência de vários artistas jovens que traziam renovação à arte brasileira, tendo sido responsáveis por uma grande diversidade de tendências identificadas por Schenberg. Sem dúvida, isso não escapou à visão do crítico, que estava atento à importância de se incentivar e apoiar esses artistas em início de carreira.

Para Mario Schenberg, era preciso ter coragem e desapego aos valores do passado e apostar na renovação daquilo que se encontrava estabelecido, fosse no campo da ciência, fosse no da cultura ou das artes. Os jovens estariam menos presos ao passado e, portanto, mais abertos ao presente e ao futuro, tendo sensibilidade privilegiada para perceber os valores em gestação. Entretanto, o crítico reconhecia que essa não era uma característica exclusiva dos indivíduos jovens. Por esse motivo, Schenberg afirmava que os "desbravadores são os jovens de espírito" 421 .

Em ambas as frentes, tanto para cientistas como para artistas, o crítico defendia o oferecimento dos meios e da liberdade necessários para que a capacidade criativa não encontrasse inibições.

Um olhar democrático para com a arte

Mario Schenberg, que não era apenas um cientista, mas um erudito, de vasta cultura literária e artística, acreditava que “(...) toda a atividade cultural deve ter um nível de autonomia e liberdade, absolutamente incompatível com qualquer

conclusões. São Paulo: Brasiliense, 1983. Com relação à intuição, Schenberg tinha como referência, ainda, o filósofo Henri Bergson, que fez uma crítica a vários aspectos da filosofia ocidental e refletiu acerca da intuição (cf. BERGSON, Henri. Ensaio sobre os Dados Imediatos da consciência. Lisboa, Edições 70.).

${ }^{420}$ PISMEL, Ana Paula Cattai. Schenberg e vanguardas: crítica como parceria. In: VIII Congresso de Estética e História da Arte, Desenhos da Pesquisa: Novas Metodologias da Pesquisa em Arte. São Paulo: Museu de Arte Contemporânea da Universidade de São Paulo, 2012, v.1, p.279-288.

${ }^{421}$ SCHENBERG, Mario. Pensando a Arte, São Paulo: Nova Stella, 1988, p. 193 (itálico nosso). 
enquadramento de ordem burocrático-formal (... $)^{422}$. Ele certamente concordaria com a célebre máxima de Albert Einstein, que dizia que tudo o que grande e inspirador só poderia ser criado por aquele que pode trabalhar com liberdade ${ }^{423}$.

Se a criatividade, seja na arte ou na ciência, só pode florescer num contexto de liberdade, o caminho para ela passa pela valorização do ser humano e de uma sociedade que cultive a liberdade. Nessa busca, são os valores democráticos que parecem os mais adequados ao crítico, não apenas na esfera política, mas no âmbito social de modo amplo.

Para Mario Schenberg, a democracia não consistia apenas na "conquista de um Estado de Direito, mas como algo mais profundo, envolvendo os seres humanos em sua individualidade: a igualdade na diversidade, algo distinto do igualitarismo. Uma relação de igualdade entre seres igualmente livres pelo conhecimento, livres pelo domínio da ciência." ${ }^{424}$ Diante disso, pode-se dizer que a postura democrática de Schenberg estava ligada a um aspecto profundamente enraizado em sua visão de mundo: o humanismo.

Não se trata, neste trabalho, de focalizar a atividade política de Mario Schenberg. Em primeiro lugar, porque o objeto desta pesquisa é a participação do crítico nas bienais de São Paulo; em segundo, porque isso já foi feito com propriedade pela pesquisadora Dina Lida Kinoshita no livro Mario Schenberg: o cientista e o político, publicado em 2014. Sua reflexão versa sobre as consequências do espírito democrático e humanista de Mario Shenberg, refletidas em sua atuação nas bienais, tendo em vista aspectos da gestão do evento, de sua atitude em relação aos artistas e à crítica de arte. A esse respeito, pode-se observar que o humanismo e o senso democrático presentes na visão de mundo de Schenberg foram elementos que perpassaram sua atuação, não apenas como cientista e como político, mas também como crítico de arte.

A fim de tecer algumas considerações sobre o olhar democrático de Mario Schenberg em relação à arte, interessa destacar dois pontos que se pode relacionar entre as considerações feitas por Dina Lida Kinoshita e a atuação do crítico nas Bienais de São Paulo. O primeiro diz respeito à maneira como Schenberg se posicionava em defesa

\footnotetext{
${ }^{422}$ KINHSHITA, Dina Lida. Mario Schenberg: o cientista e o político. Brasília: Fundação Astrogildo Pereira, 2014.

423 EINSTEIN, Albert. Pensamento político e ultimas conclusões. Seleção e prefácio de Mario Schenberg. São Paulo: Brasiliense, 1983, p. 29.

${ }^{424}$ KINHSHITA, Dina Lida. Mario Schenberg: o cientista e o político. Brasília: Fundação Astrogildo Pereira, 2014, p. 259.
} 
dos artistas e o segundo, à sua postura em relação à realidade, fruto de formação científica que permeou sua crítica de arte.

Mario Schenberg, que havia enfrentado duros embates na assembleia legislativa na década de $1940^{425}$, não se furtou de defender com a mesma firmeza o acesso dos artistas e o espaço da delegação brasileira na Bienal. Em meio aos diversos entraves enfrentados, tanto interna quanto externamente à organização das Bienais, o crítico não teve receio de defender novos paradigmas emergentes na arte e os novos artistas que desenhavam tendências em gestação.

Nas três edições do certame em que fez parte do Júri de Seleção teve em mente a necessidade de tornar visíveis artistas iniciantes que tinham propostas inovadoras, mesmo que, em termos técnicos, suas obras deixassem a desejar. Observe-se que, por conta da firmeza do posicionamento de Mario Schenberg, os artistas primitivos puderam figurar na IX Bienal:

Em 1967, os outros membros do júri da Bienal não queriam aceitar primitivos na mostra, mas Mario protestou dizendo ser isso contra os estatutos da organização e, devido a este protesto puderam entrar vários grandes primitivos como Waldomiro de Deus, Chico da Silva e José Antônio da Silva, que hoje estão entre os mais conhecidos do mundo. ${ }^{426}$

Na década de 1960, o crítico manteve proximidade com os artistas primitivos, entre eles os citados acima. Sem dúvida, esses e outros artistas de tendências diferentes ainda em gestação foram aceitos graças à abertura do crítico à nova realidade artística.

Além disso, cabe ressaltar que Schenberg tinha por hábito tomar conhecimento dos estatutos e regimentos que envolviam suas atividades na Bienal, usando esse conhecimento para reforçar sua argumentação diante dos demais membros do Júri. Com essa ferramenta, o crítico se fazia ouvir e contestava as justificativas para escolhas e recusas relativas às obras submetidas a julgamento.

Outro momento no qual Mario Schenberg demonstrou com firmeza seu posicionamento foi na X Bienal, em 1969, por ocasião do boicote - nacional e internacional - do meio artístico em protesto contra o recrudescimento da censura e as arbitrariedades do Regime Militar instaurado em 1964. O crítico permaneceu como

${ }^{425}$ Cf. KINHSHITA, Dina Lida. Mario Schenberg: o cientista e o político. Brasília: Fundação Astrogildo Pereira, 2014.

${ }^{426}$ LUYTEN, Jos. Mario Schenberg, amigo dos artistas. Jornal A Gazeta. São Paulo, 10 jun. 1972, pág. 9. 
organizador da representação brasileira que figuraria no certame e contornou, com os demais membros do Júri de Seleção, os significativos desfalques provocados pela recusa de inúmeros artistas e críticos de arte a participarem da X Bienal.

Nesse momento, ao optar por permanecer como jurado e continuar defendendo o espaço dos artistas brasileiros no evento ${ }^{427}$, Mario Schenberg era movido pela convicção de que, diante daquele contexto, em que havia cada vez menos espaço para os artistas, seria contraproducente simplesmente se retirar da Bienal. Em outras palavras, dar continuidade a sua função como membro do Júri de Seleção significava ocupar um espaço que, apesar de todos os problemas e críticas com que tinha de lidar, permanecia como o foro mais privilegiado para as Artes Plásticas no país.

Para Schenberg, às vezes é preciso enfrentar situações duras para fazer valer convicções, visão de mundo e de justiça, caso contrário perde-se um espaço que, depois, será difícil de reconquistar. Essa premissa, refletida em seu posicionamento em relação ao Boicote da Bienal no fim da década de 1960, está intimamente relacionado com uma frase que o crítico teria proferido numa reunião da base do Partido Comunista em 1956, em contexto semelhante: "Escuta, disputamos em liberdade. Mas política, você precisa lembrar, [...], é uma atividade dura em que, muitas vezes, se deve enfrentar situações internas conflitantes e violentas mesmo não estando de acordo com elas." ${ }^{428}$ Com isso, o crítico queria dizer que, apesar dos atritos e diferenças de entendimento internos ao partido, era importante persistir buscando o objetivo comum a todos, em lugar de denunciar o que estava errado, sair do partido e ir para casa.

Quanto ao segundo ponto elencado, a saber, a importância da formação científica de Mario Schenberg, acredita-se que a observação de Dina Lida Kinoshita a respeito da prevalência da realidade em relação ao universo teórico pode ser pensada também em relação à sua atuação no meio artístico. Na obra Mario Schenberg: o cientista e o político, a autora atribui essa característica da visão de mundo do crítico a sua formação científica:

Schenberg nunca abdicou da ideia de que a realidade é mais importante que o raciocínio lógico. Esse fato deve ser decorrência da própria natureza da formação dele, basicamente científica. Ele não era um intelectual puro, no sentido de que a fonte de inspiração dele da atividade dele era subjetiva, mas um cientista que, apesar de se

\footnotetext{
${ }^{427}$ AMARANTE, Leonor. As Bienais de São Paulo: 1951 a 1987. São Paulo: Projeto, 1989, p. 184. ${ }^{428}$ KINHSHITA, Dina Lida. Mario Schenberg: o cientista e o político. Brasília: Fundação Astrogildo Pereira, 2014, p. 278.
} 
interessar pelas formas mais abstratas e teóricas de conhecimento da física teórica, ao mesmo tempo ele partia da análise da observação da natureza. É muito provável que, ao analisar um fenômeno social, desse grande importância às situações objetivas. ${ }^{429}$

A pesquisadora compara, em seguida, a relação com a realidade que têm o cientista da natureza e o cientista social. Segundo seu argumento, o modus operandi do contato com a realidade e com a teoria seria diferente na formação desses dois tipos de cientistas. De um lado, os cientistas sociais teriam, primeiro, o contato com a teoria, apropriando-se dela e desenvolvendo sua apreciação no plano teórico individual. Desse modo, ao entrarem em contato com a realidade, enfrentam dificuldades para lidar com os aspectos que não podem ser explicados pela teoria. Isso seria motivado pelo apego à teoria como explicação da realidade. De outro, está o cientista da natureza cuja formação vai no sentido de, a partir da realidade, realizar experimentos e pesquisas que busquem explicá-la. Por isso, essa classe de cientistas tenderia a ter menos problemas para reconhecer mudanças da realidade, pois é com base no que observa que buscará aporte teórico para sustentar sua interpretação ${ }^{430}$.

Levando-se em conta essas diferenças, argumenta-se que, ao se integrar aos artistas e se fazer presente nos movimentos artísticos ${ }^{431}$, buscando conhecer e analisar artistas e tendências, Mario Schenberg tinha facilidade em voltar sua atenção para os novos dados que essa realidade oferecia para, sem amarras conceituais nem cunho valorativo, fazer sua análise a respeito das mudanças que ocorriam na arte.

Sobre isso, o artista José Roberto Aguilar afirmou que quando se tratava de Mario Schenberg, não havia espaço para dogmatismo, pois o crítico era de uma grande abertura. Em princípio, tudo era tomado como plausível e ouvido com atenção, até que Schenberg pudesse refletir sobre o que encontrava ${ }^{432}$. Essa característica de sua natureza estava presente tanto nas conversas, em que ouvia sempre com atenção a todos os tipos de assuntos, quanto em seu contato com as obras de arte, as quais eram observadas por um período no qual o crítico ficava em silêncio para, só depois, se manifestar.

\footnotetext{
${ }^{429}$ KINHSHITA, Dina Lida. Mario Schenberg: o cientista e o político. Brasília: Fundação Astrogildo Pereira, 2014, p. 279.

${ }^{430}$ KINHSHITA, Dina Lida. Mario Schenberg: o cientista e o político. Brasília: Fundação Astrogildo Pereira, 2014, p. 281.

${ }^{431}$ LUYTEN, Jos. Mario Schenberg, amigo dos artistas. Jornal A Gazeta. São Paulo, 10 jun. 1972, pág. 9.

${ }^{432}$ AGUILAR, José Roberto. Entrevista concedida a Ana Paula Cattai Pismel. São Paulo, 10 mai. 2018. 1 arquivo .mp3 (21'). [A entrevista encontra-se depositada no Centro Mario Schenberg de Documentação da Pesquisa em Arte - ECA/USP].
} 
Outro dado interessante a ser registrado é que, para Mario Schenberg, as diversas tendências que surgiam, uma após a outra, não estavam superadas apenas pelo fato de uma nova tendência ter emergido. Em outras palavras, todas as tendências eram relevantes enquanto linguagens artísticas e, por isso, não era o caso de as novas tendências deporem as anteriores. Por exemplo, a Nova Figuração teria colocado de lado a Abstração, que, por sua vez, havia sido imposta sobre o Realismo Social. Na visão do crítico, apesar de haver uma certa autofagia na arte brasileira, que torna obsoleta a tendência dominante anterior, tudo é possível e plausível quando se trata dos caminhos que um artista encontra para se expressar. Nesse sentido, um artista primitivo e uma figura como Mira Schendel estão no mesmo patamar de relevância e guardam o mesmo potencial $^{433}$.

Coloca-se assim em evidência a fecundidade da postura aberta e sem pressupostos do crítico, bem como sua fecundidade no contexto do Júri de Seleção das Bienais de São Paulo. Sem dúvida, o perfil de Mario Schenberg encontrou nesse contexto um terreno fértil nos inúmeros contatos com artistas brasileiros e estrangeiros, bem como outros críticos de arte e intelectuais. De um lado, o crítico adentrou um universo privilegiado no mundo das artes, como era a Bienal então, estando inserido diretamente nesse espaço de debate; de outro, encontrou receptividade em diversos artistas e na própria Bienal, trazendo a ela novos ares.

433 AGUILAR, José Roberto. Entrevista concedida a Ana Paula Cattai Pismel. São Paulo, 10 mai. 2018. 1 arquivo .mp3 (21'). [A entrevista encontra-se depositada no Centro Mario Schenberg de Documentação da Pesquisa em Arte - ECA/USP]. 
Figura 57 - Mario Schenberg e Amélia Império Hamburguer. Década de 1960.

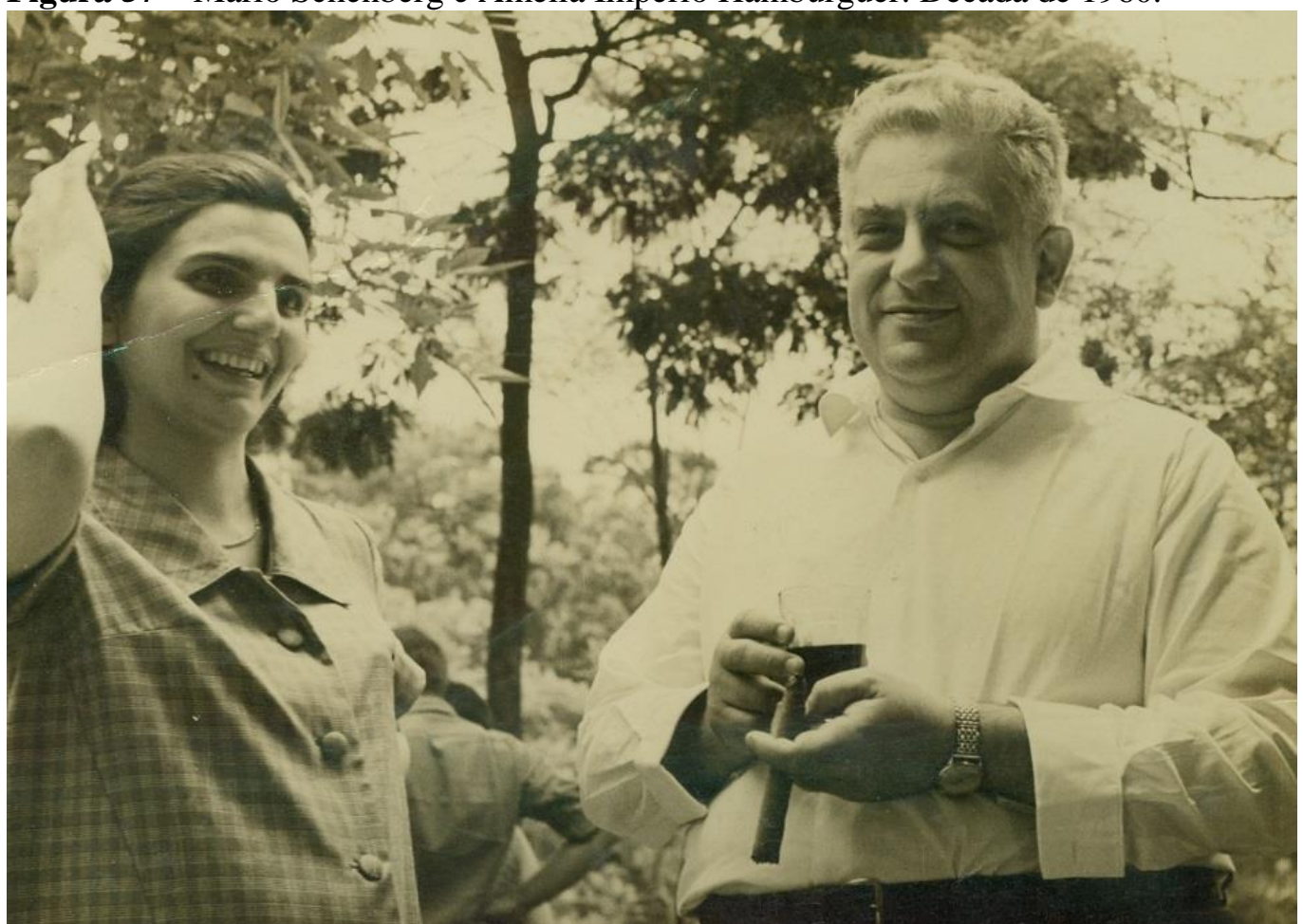

Fonte: Acervo Histórico do Instituto de Física da USP.

Figura 58 - Mario Schenberg autografando o livro Pensando a Física. $36^{\text {a }}$ Reunião anual da SBPC, realizada na USP. São Paulo, julho de 1984.

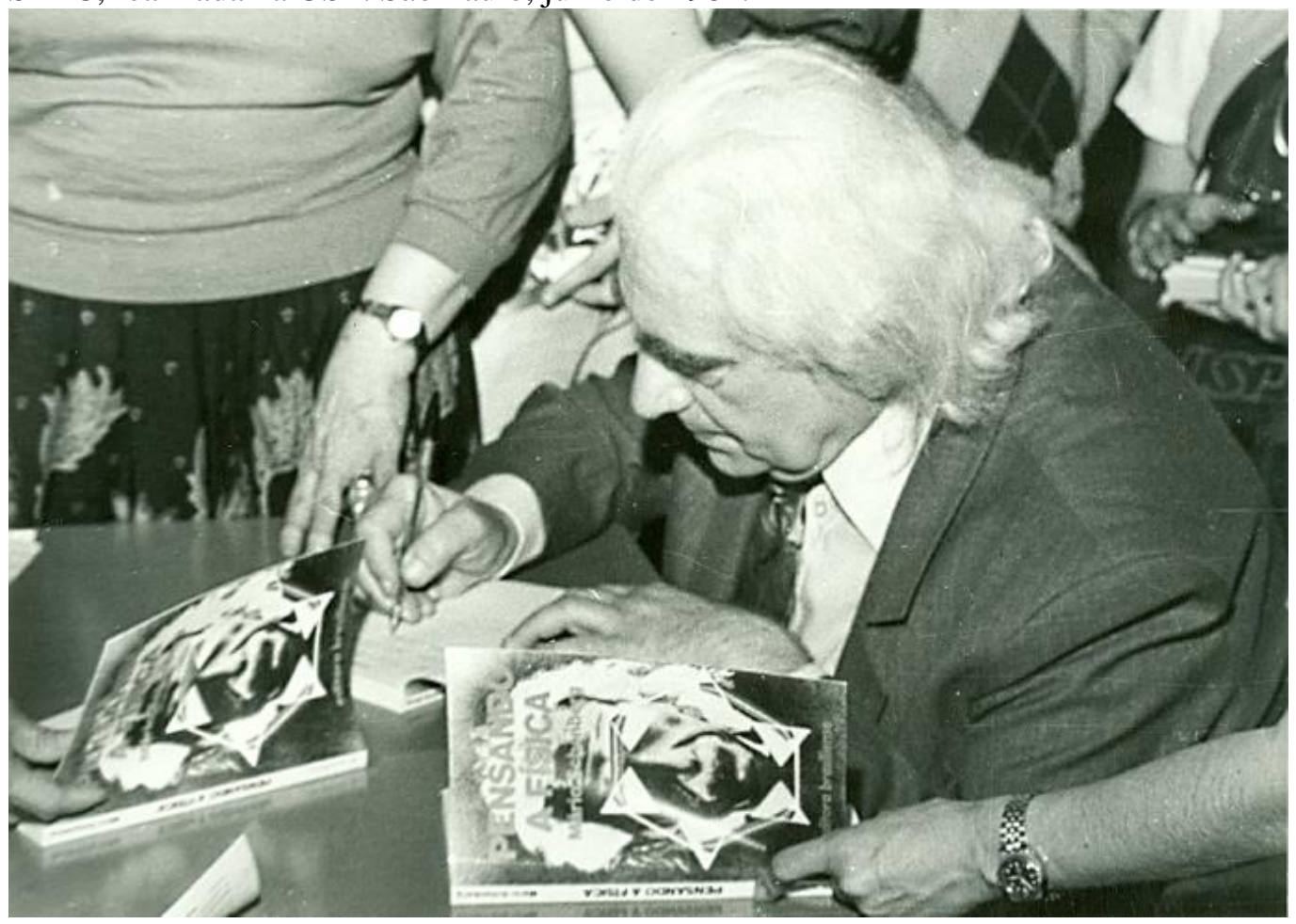

Fonte: Acervo Histórico do Instituto de Física da USP. 


\title{
Considerações Finais
}

\begin{abstract}
A liberdade cultural garante a liberdade em sua totalidade, protegendo não apenas os direitos do grupo, mas também os de todos os seus membros. Ao proteger esses diversos modos de vida, a liberdade cultural estimula a experimentação, a diversidade, a imaginação e a criatividade; nos permite satisfazer uma das necessidades mais fundamentais, precisamente o direito de definir quais são essas necessidades fundamentais ${ }^{434}$ [tradução nossa].
\end{abstract}

UNESCO

A atuação de Mario Schenberg nas Bienais Internacionais de São Paulo foi relevante, sobretudo ao se levar em conta sua contribuição para os Júris de Seleção da mostra na década de 1960, em que estavam presentes a efervescência cultural e a repressão política do Regime Militar. Esta pesquisa foi norteada pelo questionamento acerca das razões que teriam levado o crítico, mundialmente reconhecido enquanto físico teórico, a se envolver na organização desses eventos, bem como a assumir as posições político-estéticas por ele defendidas.

Diante da enorme tarefa que Mario Schenberg tinha a sua frente, a saber, reunir uma amostra significativa de todas as fases do pintor Alfredo Volpi, que até aquele momento já contava com cerca de quatro décadas de atividade, percebe-se que um dos fatores determinantes para seu sucesso foi sua familiaridade, tanto com o artista quanto com os principais apreciadores e colecionadores da obra de Volpi.

O crítico já tinha, até mesmo, sido votado para integrar o Júri de Seleção da Bienal anterior (1959), o que pode ser tomado como um indicativo de sua popularidade entre os artistas muito antes de sua entrada efetiva no grupo seleto daqueles que escolhiam o que entrava ou não no privilegiado espaço da Bienal.

\footnotetext{
${ }^{434}$ No original: "La libertad cultural garantiza la libertad en su totalidad, al proteger no sólo los derechos del grupo, sino también los de todos sus miembros. Al proteger estos diversos modos de vida, la libertad cultural estimula la experimentación, la diversidad, la imaginación y la creatividad; nos permite satisfacer una de las necessidades más fundamentales, precisamente el derecho a definir cuáles son estas necesidades fundamentales". UNESCO. Nuestra diversidade creativa - Informe de la Comisión Mundial de Cultura y Desarrollo. Madrid: Fundación Santa María/Ediciones SM, 1997, p. 11. Disponível em: 〈http://unesdoc.unesco.org/images/0010/001036/103628s.pdf〉. Acesso em 3 mar. 2018.
} 
Frequentando o cenário cultural desde o fim da década de 1930, Mario Schenberg já fazia parte dos círculos de convivência dos principais nomes do Movimento Modernista, como Oswald de Andrade, e do Grupo Santa Helena, como Bruno Giorgi e Alfredo Volpi. Por isso, dá-se a ver a figura de Schenberg como um grande promotor cultural, com quem somente um artista muito desconhecido não teria contato $^{435}$. Pode-se afirmar que seu sucesso na organização da sala especial se deu por sua forte inserção no meio artístico da época, não apenas enquanto crítico de arte, mas também como incentivador dos artistas com os quais convivia ${ }^{436}$.

Em meio a essa tarefa, Mario Schenberg teve que contornar uma dificuldade: reunir trabalhos de todas as fases de um pintor cuja carreira fora iniciada na década de 1920. Contando então com uma trajetória de quatro décadas, que compreendeu inúmeras fases, a obra de Volpi oferecia um desafio e tanto à realização de uma exposição retrospectiva. Essa dificuldade foi ainda maior com relação aos trabalhos anteriores à década de 1940, que já estavam bastante dispersos.

É importante notar que a sala especial organizada por Mario Schenberg teve repercussão favorável na imprensa, na medida em que apresentou com eficiência e caráter didático todas as fases de Alfredo Volpi até aquele momento. Mesmo entre os visitantes estrangeiros a mostra foi bem vista ${ }^{437}$. Outro aspecto positivo apontado foi a abundância de documentação da pesquisa empreendida por Volpi, que permitia ao visitante compreender o peso de seu trabalho na vida artística do país ${ }^{438}$. Para o pintor, certamente essa projeção foi um grande incentivo, tanto artístico quanto financeiro, à continuidade de sua pesquisa estética.

A obra de Alfredo Volpi reunia elementos do construtivismo, tão caro a Mário Pedrosa, e da arte popular, evidenciada por Mario Schenberg. Os dois críticos se aproximavam no interesse pelo pintor e pelo projeto das Bienais. Nesse sentido, e Mario Schenberg foi convidado a fazer parte da organização do certame por escolha do próprio Volpi, quando consultado por Mário Pedrosa.

\footnotetext{
${ }^{435}$ Mario Schenberg, amigo dos artistas. Jornal A Gazeta. São Paulo, 10 jun. 1972, p. 9.

${ }^{436}$ PISMEL, Ana Paula Cattai. Schenberg e vanguardas: crítica como parceria. In: VIII Congresso de Estética e História da Arte, Desenhos da Pesquisa: Novas Metodologias da Pesquisa em Arte. São Paulo: Museu de Arte Contemporânea da Universidade de São Paulo, 2012. v.1. p. 279-288.

${ }^{437}$ Pintura, Desenho e Opiniões. Correio Paulistano, São Paulo, 22 dez. 1961.

${ }^{438}$ MARTINS, Vera. Roteiro da Bienal. Jornal do Brasil, 27 ago. 1961.
} 
A contribuição da artista Maria Bonomi $(2008)^{439}$ permitiu aquilatar novos aspectos da aproximação entre Mario Schenberg e a Bienal. Com base no convívio que teve com Ciccillo Matarazzo, a artista relata que o empresário tinha uma percepção bastante abrangente do meio cultural e sabia que Mario Schenberg teria muito a oferecer à Bienal. A presença do crítico no certame tinha propósitos claros: primeiramente, por sua proximidade com os artistas e seu interesse pela arte e, em segundo lugar, por sua capacidade de trazer um novo olhar para com as obras de arte, que poderia agregar a singularidade da figura de Mario Schenberg ao quadro da Bienal. Ciccillo Matarazzo tinha a intenção de atualizar o debate que havia no certame, além de contar com o peso que o reconhecimento internacional da carreira científica de Schenberg agregava ao seu nome. Lembre-se, é claro, da importante presença de Yolanda Penteado na trajetória das Bienais Internacionais de São Paulo desde a primeira edição, em 1951.

Apesar de manter em sua pessoa o controle da Bienal, o empresário soube reunir, no que diz respeito ao período delimitado, os maiores nomes nacionais e estrangeiros para atuar na organização da mostra. A tais pessoas, que tinham diferentes visões e níveis de envolvimento com o debate artístico, Ciccillo delegou o poder de fazer as escolhas necessárias para as Bienais acontecerem. Ciccillo Matarazzo defendeu a presença de Mario Schenberg na Bienal, mesmo diante dos questionamentos a respeito da posição ideológica do crítico. O que importava para Ciccillo era sua contribuição diferenciada enquanto crítico de arte, independentemente de questões políticas.

Mario Schenberg, por sua vez, também respeitava muito o mecenas que tomava para si o encargo de realizar as bienais, pois admirava o empresário, bem como sua atitude em prol da arte e da cultura do país. Para o crítico, Ciccillo era um pioneiro, alguém que estava fazendo algo para construir o país, mesmo com os diversos riscos que isso acarretava. Pode-se dizer que Mario Schenberg e Ciccillo Matarazzo se comprometeram em torno da questão da Bienal, dado que para o certame era importante contar com o crítico, enquanto para Schenberg o espaço a ele garantido e a liberdade com que poderia atuar eram muito importantes.

Nos júris de seleção das bienais de 1965, 1967 e 1969, o crítico representou os artistas, argumentando a favor deles, mantendo-se firme e demostrando conhecimento dos regulamentos envolvidos no desempenho de sua função. Quando julgou necessário,

\footnotetext{
439 [Informação verbal] BOMONI, Maria. Entrevista concedida a Ana Paula Cattai Pismel. São Paulo, 16 mai. 2018. 4 arquivos .mp3 (1h46'15'). [A entrevista encontra-se depositada no Centro Mario Schenberg de Documentação da Pesquisa em Arte - ECA/USP].
} 
Mario Schenberg se posicionou com assertividade nos debates com outros membros do júri, defendendo sempre a abertura da representação brasileira da Bienal de São Paulo a todos os artistas, fossem eles experientes ou iniciantes. Ele entendia que era função do certame promover visibilidade para os novos artistas que começavam a desenvolver seu trabalho e a definir novos caminhos para a arte.

A Bienal de 1965 abria as portas ao grande público um ano e meio depois do golpe militar de 1964. Apesar de a censura ter sido mais intensa de 1968 em diante, em decorrência do Ato Institucional $n^{\circ} 5^{440}$, a repressão já começava a fazer parte do horizonte cultural e político do país. Repercutindo imediatamente na estrutura de poder da Universidade de São Paulo, foi no ambiente acadêmico que a perseguição política atingiu Mario Schenberg. Durante a década de 1960, Schenberg encontrou entre os artistas o apoio que possibilitou sua atuação, mesmo sob os mandados de prisão e a perseguição política de que foi alvo. Neste estudo, foram destacados os casos do humorista Jô Soares e da poetisa Hilda Hilst, além de seus colegas da Faculdade de Filosofia, Ciências e Letras da USP, que criaram estratégias para que a ausência do crítico do ambiente acadêmico não caracterizasse abandono de cargo, o que o levaria a ser exonerado de sua posição como docente (MOTTA, 2014).

Assinale-se que a reconstituição das datas nas quais Schenberg esteve ou não sob ameaça de prisão no decorrer de 1965 tornou possível avaliar como se deu sua participação nos trabalhos do Júri de Seleção da Bienal no período conturbado vivido pelo crítico entre 1964 e 1965, como foi mostrado no capítulo 2. Diferentemente do que a literatura registrava até o momento, o crítico não enfrentava restrições quando foram realizadas as reuniões de seleção das obras que fizeram parte da VIII Bienal. Uma vez integrando o Júri, Mario Schenberg não hesitou em defender os artistas com os quais mantinha contato, lembrando que, naquele momento, o crítico se aproximou de artistas como José Roberto Aguilar, Cláudio Tozzi, Rubens Guerchmann e Waldomiro de Deus.

O crítico, porém, não compareceu à inauguração da VIII Bienal de São Paulo em 4 de setembro, pois, apenas três dias antes, havia sido expedido contra ele um mandado de prisão. O Congresso Internacional de Partículas Elementares se aproximava e Mario Schenberg não tinha obtido permissão para viajar ao Japão. Embora conste até o momento que, quando da inauguração da Bienal, Schenberg estivesse preso, foi somente em 22 de setembro que o crítico se entregou, fato que teve repercussão internacional.

${ }^{440}$ SCHWARZ, Roberto. Cultura e Política, 1964-69. In O Pai de Família e outros estudos. Rio de Janeiro: Paz e Terra, 1978. 
Em 24 de setembro, apenas dois dias depois, foi expedido um habeas corpus em favor de Schenberg, que já no dia seguinte embarcou para o Japão ${ }^{441}$.

A Bienal de 1967 foi a última edição do evento antes do Ato Institucional $\mathrm{n}^{\circ} 5$, decretado no fim de 1968 e que, no ano seguinte, causaria estragos à vida cultural do país. A ausência de uma definição da atividade da crítica de arte no regulamento da IX Bienal levantou a polêmica em torno da aceitação de Mario Schenberg como membro do Júri de Seleção nas edições das quais participou; apesar de ser considerado como crítico pelos artistas, seu nome foi recebido com dúvidas pela Fundação Bienal. Nessa ocasião, Schenberg recebeu não só o apoio da Associação Internacional de Artistas Plásticos (cujo presidente era o artista Maurício Nogueira Lima), mas também o da Associação Internacional de Críticos de Arte, que o aceitou em seus quadros. Tal fato é significativo, pois evidencia o prestígio que o crítico angariou entre os artistas e o respeito que passou a obter dos demais críticos de arte. Com esse apoio seu nome foi legitimado, tornando a polêmica um caso superado.

Ao escrever sobre a IX Bienal de São Paulo, o crítico afirmou que "o maior mérito do júri da seleção [...] foi ter compreendido o momento revolucionário atual da arte brasileira e de ter dado prioridade às inovações, mesmo quando apresentadas em obras com deficiências de execução" ${ } 442$. O crítico destacou, ainda, a relevância da compreensão de que a qualidade dizia respeito à "riqueza de concepção experimental e de intuição pioneira", e não simplesmente à dimensão artesanal do acabamento da obra de arte. Nesse sentido, as obras selecionadas para a IX Bienal de São Paulo teriam dado uma "imagem impressionante da vitalidade do movimento artístico brasileiro atual" ${ }^{443}$.

Na contramão do que se costumava dizer na época, constatou-se que o crítico não defendia todas as obras apresentadas ao júri. Porém, quando se deparava com trabalhos que despertavam seu interesse, o crítico argumentava em favor deles, buscando convencer os colegas sobre seu mérito de modo vivo, mas sempre polido ${ }^{444}$. No entender de Schenberg, "o grave não é deixar entrar um artista ruim, que tem uma

\footnotetext{
${ }^{441}$ Schenberg foi para o congresso no Japão. Última Hora, 27 set. 1965.

${ }^{442}$ SCHENBERG, Mario. Pensando a Arte. São Paulo: Nova Stella, 1988, p. 194.

${ }^{443}$ SCHENBERG, Mario. Pensando a Arte. São Paulo: Nova Stella, 1988, p. 196.

444 [Informação verbal] MAGALHÃES, Fábio. Entrevista concedida a Ana Paula Cattai Pismel. São Paulo, 5 abr. 2018. 12 arquivos .MOV (1h52'22'”). [A entrevista encontra-se depositada no Centro Mario Schenberg de Documentação da Pesquisa em Arte - ECA/USP].
} 
obra fraca; o grave é nós impedirmos uma obra boa de entrar" ${ }^{\text {"45 }}$. Outra atitude do crítico foi a busca ativa por novos talentos, por meio da qual artistas como Marcelo Nitche e Carmela Gross, por exemplo, puderam integrar as bienais pela primeira vez ${ }^{446}$. Note-se que ambos os artistas estiveram presentes, também, na edição de 1969, permanecendo ao lado de Schenberg quando do boicote.

Note-se que o crítico valorizou o processo criativo dos artistas brasileiros. $\mathrm{Na}$ década de 1960, manteve proximidade com artistas como Waldomiro de Deus, Chico da Silva e José Antônio da Silva, que encontraram resistência e contaram com a defesa de Mario Schenberg para integrarem a IX Bienal ${ }^{447}$.

No fim de 1968, sobreveio o endurecimento da censura, que repercutiu em diversas instituições públicas federais, estaduais e municipais. $\mathrm{O}$ decreto atingiu, no início do ano seguinte, vários professores e funcionários da Universidade de São Paulo, que foram demitidos ou aposentados compulsoriamente em abril de 1969, restringindo atividades políticas e manifestações culturais ${ }^{448}$. Entre eles estava o Professor Mario Schenberg, que passou então a dedicar mais tempo à crítica de arte, uma vez que foi impedido até mesmo de frequentar bibliotecas e ambientes universitários.

Marcada pelo boicote internacional, ao qual aderiram artistas, críticos de arte e intelectuais, todas as fases da realização da X Bienal apresentaram problemas que, com maior ou menor êxito, foram contornados pela Comissão Técnica e pelo Júri de Seleção, que organizou várias salas especiais, além da sala geral da representação brasileira. Nesse contexto, Mario Schenberg optou por levar adiante sua função de jurado na seleção das obras daquela edição. O crítico não apenas se posicionou contra o boicote como organizou a sala Novos Valores, assinando o texto de apresentação no catálogo da mostra ${ }^{449}$.

\footnotetext{
445 [Informação verbal] MAGALHÃES, Fábio. Entrevista concedida a Ana Paula Cattai Pismel. São Paulo, 5 abr. 2018. 12 arquivos .MOV (1h52'22''). [A entrevista encontra-se depositada no Centro Mario Schenberg de Documentação da Pesquisa em Arte - ECA/USP].

${ }^{446}$ [Informação verbal] TORRES, Caciporé. Entrevista concedida a Ana Paula Cattai Pismel. São Paulo, 8 mai. 2018. 1 arquivo .mp3 (16'39'). [A entrevista encontra-se depositada no Centro Mario Schenberg de Documentação da Pesquisa em Arte - ECA/USP].

${ }^{447}$ LUYTEN, Jos. Mario Schenberg, amigo dos artistas. A Gazeta. São Paulo, 10 jun. 1972, pág. 9.

${ }^{448}$ Folha registrou trajetória de FHC, da USP à Presidência. Folha de São Paulo, 18 jun. 2011.

${ }^{449}$ AMARANTE, Leonor. As Bienais de São Paulo: 1951 a 1987. São Paulo: Projeto, 1989, p. 184. Cf. texto de apresentação da sala especial em SCHENBERG, Mario. Novos Valores. In FUNDAÇÃO BIENAL. X Bienal (catálogo de exposição). São Paulo: Museu de Arte Moderna de São Paulo, 1969, p. 445.
} 
Ao optar por não abandonar a organização da Bienal e continuar defendendo o espaço dos artistas brasileiros no evento ${ }^{450}$, Mario Schenberg era movido pela convicção de que, diante daquele contexto, em que havia cada vez menos espaço para os artistas, seria contraproducente se retirar. Em outras palavras, dar continuidade a sua função como membro do Júri de Seleção significava ocupar um espaço que, apesar de todos os problemas e críticas com que tinha de lidar, permanecia como o foro mais privilegiado para as Artes Plásticas no país.

A permanência de Schenberg na Bienal, juntamente com outros críticos e artistas, ajudou a manter o evento de pé, minimizando os prejuízos ${ }^{451}$. A Bienal havia se tornado uma mostra que reunia questões não só das esferas artística, estética e cultural, mas também política e social. Nesse sentido a contribuição de Schenberg foi decisiva.

É preciso destacar que a trajetória das bienais de São Paulo analisada neste trabalho foi marcada por crises, mas também por conquistas, na medida em que nela havia lugar para o debate. Se por um lado as críticas traziam à tona impasses e destacavam problemas das bienais, por outro evidenciavam a existência de um espaço em que havia a possibilidade de coexistência de diferentes visões e de inúmeros agrupamentos artísticos. Em vista disso, num contexto em que as liberdades individuais eram tolhidas em nome da repressão imposta desde a instauração do Regime Militar, o ambiente da Bienal era extremamente atrativo para artistas, críticos de arte e intelectuais.

À luz do aprofundamento da investigação, foi possível compreender que, embora Mario Schenberg não pudesse mais participar dos júris de seleção, não era intenção da Bienal deixar de contar com o crítico. Porém, uma vez que Schenberg ficava impedido de tomar parte até mesmo nesses eventos, Ciccillo Matarazo teria optado por resguardar tanto o crítico, que estava sob vigilância contínua, quanto a própria Bienal, que perderia muito com os problemas que a presença de Schenberg implicaria após o AI-5.

Além disso, é altamente provável que o próprio Mario Schenberg tenha optado por não colocar em risco as inúmeras pessoas com as quais ele teria contato publicamente caso continuasse a exercer suas funções nas bienais. Pelo que foi possível

\footnotetext{
${ }^{450}$ AMARANTE, Leonor. As Bienais de São Paulo: 1951 a 1987. São Paulo: Projeto, 1989, p. 184. ${ }^{451}$ [Informação verbal] TORRES, Caciporé. Entrevista concedida a Ana Paula Cattai Pismel. São Paulo, 8 mai. 2018. 1 arquivo .mp3 (16’39''). [A entrevista encontra-se depositada no Centro Mario Schenberg de Documentação da Pesquisa em Arte - ECA/USP].
} 
aquilatar, pode-se supor que o crítico tivesse a dimensão de que seu afastamento das bienais fora motivado estritamente pela conjuntura política, dado o respeito mútuo que havia entre ele e Ciccillo Matarazzo.

Seu posicionamento em favor da liberdade de pesquisa e da autonomia, bem como a necessidade de valorizar o aspecto criativo na arte e na ciência, nortearam seus esforços no sentido de pensar os problemas da cultura científica de sua época e os impasses da Bienal em relação às transformações da arte. O crítico defendia a criação de condições que permitissem tanto ao cientista quanto ao artista terem os meios e a liberdade necessários para que sua capacidade criativa não encontrasse inibições.

Evidencia-se, pois, a fecundidade da postura aberta e sem pressupostos do crítico, bem como sua relevância no contexto do Júri de Seleção da Bienal Internacional de São Paulo. Sem dúvida, o perfil de Mario Schenberg encontrou nesse contexto um terreno fértil nos inúmeros contatos com artistas brasileiros e estrangeiros, bem como outros críticos de arte e intelectuais. De um lado, o crítico adentrou um universo privilegiado no mundo das artes, como era a Bienal então; de outro, encontrou receptividade em diversos artistas e na própria Bienal, trazendo a ela novos ares. 
Figura 59 - Mário Gruber, Retrato de Mario Schenberg, 1978. Óleo sobre tela, $64.00 \mathrm{~cm}$ x $53.00 \mathrm{~cm}$. No período delimitado nesta pesquisa, o artista participou da bienal nos anos de 1961, 1953, 1955, 1963, 1965, 1967 e 1971.

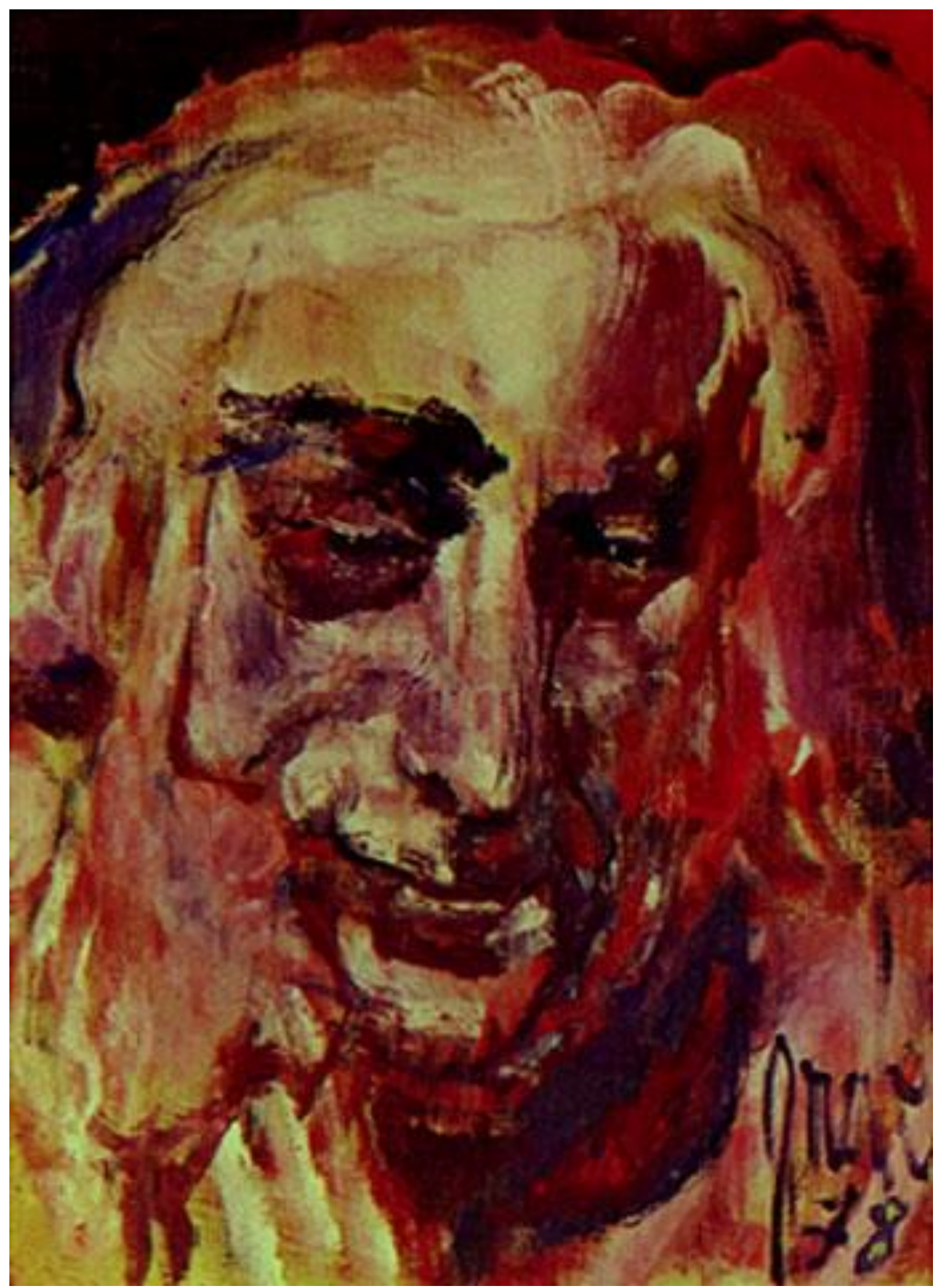

Fonte: RETRATO de Mário Schenberg. In: ENCICLOPÉDIA Itaú Cultural de Arte e Cultura Brasileiras. São Paulo: Itaú Cultural, 2018. Disponível em: <http://enciclopedia.itaucultural.org.br/obra6006/retrato-de-mario-schenberg>. Acesso em: 25 de Jun. 2018. 
Figura 60 - Mario Schenberg, s. d. Autora: Ana Clara Guerrini Schenberg.

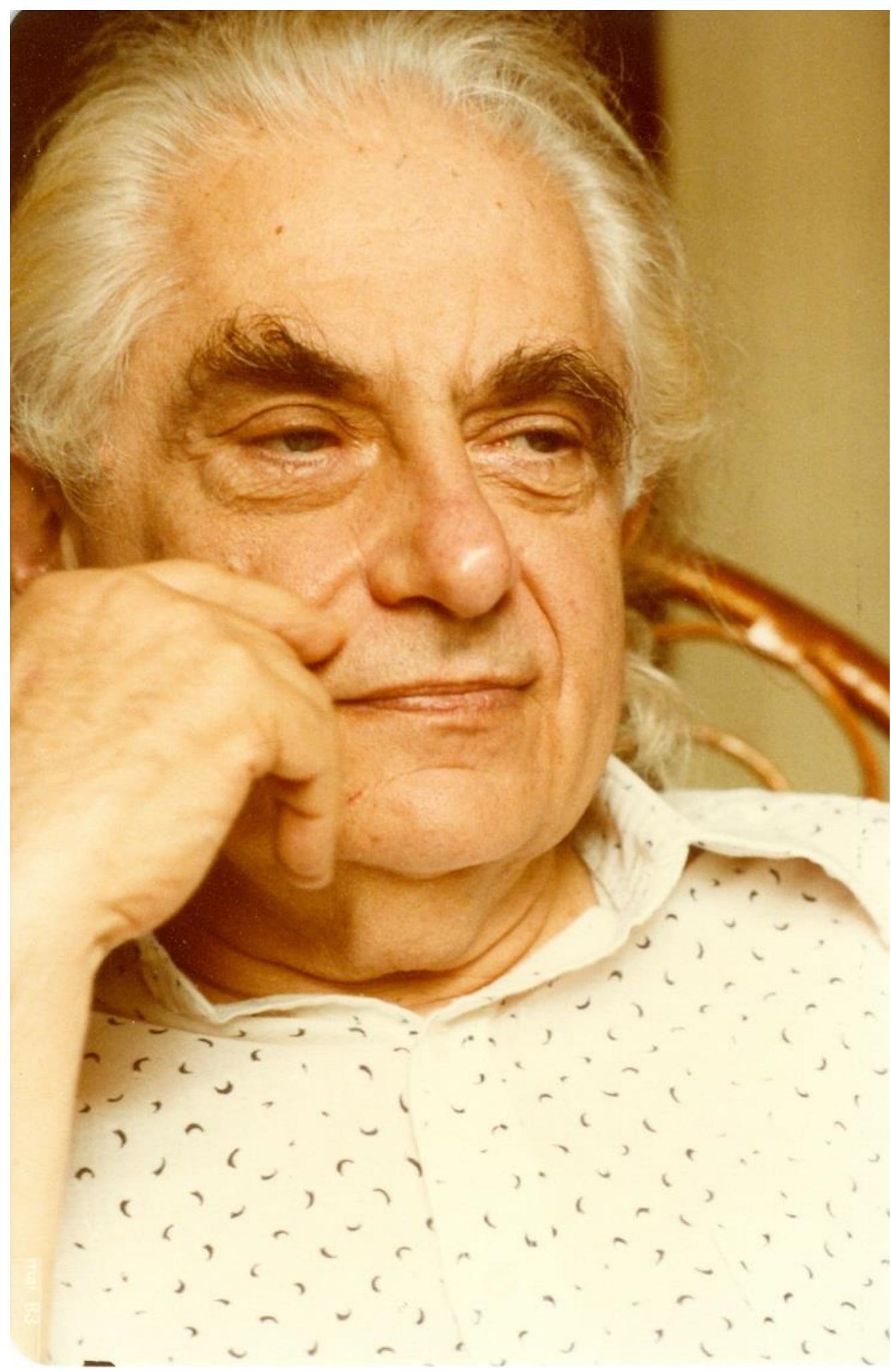

Fonte: Acervo Histórico do Instituto de Física da USP. 


\section{Referências Bibliográficas ${ }^{452}$}

\section{Específicas}

Livros, Capítulos e Artigos

AGUILAR, José Roberto. O mundo de Mario Schenberg. São Paulo: Casa das Rosas, 1996.

AJZENBERG, Elza. M. Schenberg: a crítica e o olhar da descoberta. In: O mundo de Mario Schenberg. São Paulo: Casa das Rosas, 1996.

$-2001)$. . (org.). Schenberg - Arte e Ciência. São Paulo: ECA USP (Coleção, 1995

AJZENBERG, Elza. A formação da coleção. In: AJZENBERG, Elza. Ciccillo: Acervo MAC USP - Homenagem a Francisco Matarazzo Sobrinho. São Paulo: MAC USP, 2006.

MAC Virtual: Prêmios das Bienais. São Paulo: MAC USP, 2004.

Schenberg: a crítica e o olhar da descoberta. In: O mundo de Mario Schenberg. São Paulo: Casa das Rosas, 1996.

ALAMBERT, Francisco e LOPES, Polyana Canhête. As Bienais de São Paulo: da Era dos Museus à Era dos Curadores (1951- 2001), São Paulo: Boitempo, 2004. $256 \mathrm{pp}$.

ALMEIDA, Fernando Azevedo de. O franciscano Ciccillo. São Paulo: Livraria Pioneira, 1976.

ALMEIDA, Paulo Mendes. De Anita ao Museu. São Paulo: Perspectiva, 1976.

AMARAL, Aracy. Bienais ou Da impossibilidade de reter o tempo. REVISTA USP, São Paulo, n. 52, p. 16-25, dezembro/fevereiro 2001-2002.

AMARAL, Aracy. (org.) Museu de Arte Contemporânea da Universidade de São Paulo: perfil de um acervo. São Paulo, Techint, 1988.

AMARANTE, Leonor. As Bienais de São Paulo: 1951-1987. São Paulo: Projeto, 1989. $407 \mathrm{pp}$.

ARANTES, Otília Beatriz Fiori. De Opinião-65 a XVIII Bienal. In: Novos Estudos. (15), São Paulo, CEBRAP, jul.1986. pp. 69-84.

452 De acordo com a Associação Brasileira de Normas Técnicas. NBR 6023. 
BARROS Alberto Luis da Rocha. Schenberg: Nada do que é Humano lhe era Estranho. In Estudos Avançados, 11(5), 1991.

CAMPOS, Haroldo de. Apresentação. In GOLDFARB, José Luiz. Voar também é com os Homens. São Paulo: EDUSP, 1994.

CEDRAN, Lourdes (Coord.). Diálogos com Mario Schenberg. São Paulo: Nova Stella, 1985.

CEDRAN, Lourdes. Lourdes Cedran. In SCHENBERG, Mario. Mario Schenberg: Entre-Vistas. São Paulo: Perspectiva, 1984.

CLARK, Lygia. Lygia Clark. In SCHENBERG, Mario. Mario Schenberg: EntreVistas. São Paulo: Perspectiva, 1984.

CENTRO DE ESTUDOS DE ARTE CONTEMPORÂNEA. Arte em revista. São Paulo, Centro de Estudos de Arte Contemporânea, 1979-.

DOCUMENTO 4: Discurso do Deputado Caio Prado Junior na sessão do dia 2 de outubro. In: MOTOYAMA, S.; Hamburger, A.I.; NAGAMINI, M. (Orgs.) Para uma história da FAPESP: marcos documentais. São Paulo: FAPESP, 1999. p. 66.

DURAND, José Carlos. Arte, Privilégio e Distinção: artes plásticas, arquitetura e classe dirigente no Brasil (1855 - 1985). São Paulo: Perspectiva, 1989.

FERNANDES. Eva. Mario: Crítico de Arte. In AJZENBERG, Elza. Schenberg: Arte e Ciência. São Paulo: ECA/USP, 1997, pp. 82-6.

FUNDAÇÃO BIENAL DE SÃO PAULO. Anais do Simpósio sôbre Ciência e Humanismo. São Paulo: outubro de 1971.

GOLDFARB, José Luiz. Voar também é com os Homens. São Paulo: EDUSP, 1994.

José Luis Goldfarb. In AJZENBERG, Elza. In Schenberg: Arte e Ciência. São Paulo: ECA/USP, 1997, pp. 43-50.

GUINSBURG, Gita K.; GOLDFARB, José Luiz (Org.). Mario Schenberg: EntreVistas. São Paulo: Perspectiva, 1984.

GULLAR, Ferreira \& PEDROSA, Mário. Arte brasileira hoje: situação e perspectivas. Rio de Janeiro: Paz e Terra, 1973.

HAMBURGUER, Amélia Império et al. Obra Científica de Mario Schönberg. Volume 1. São Paulo: EDUSP, 2009.

Nota biográfica e entrevista com Mario Schenberg (Novembro, 1983). São

Paulo: Instituto de Física, Universidade de São Paulo, 1984. 
HILST, Hilda. Da Poesia. 1a edição. São Paulo: Companhia das Letras, 2017

HILST, Hilda. Fico besta quando me entendem: entrevistas com Hilda Hilst. Cristiano Diniz (org.) São Paulo: Globo, 2013.

KINHSHITA, Dina Lida. Mario Schenberg: o cientista e o político. Brasília: Fundação Astrogildo Pereira, 2014.

A Política para Mario Schenberg, s.p. (texto digitado - Arquivo do Centro Mario Schenberg de Documentação da Pesquisa em Artes - ECA/USP).

LIMA, Maurício Nogueira. Mario Schenberg: incentivador e crítico. In AJZENBERG, Elza (org.). Schenberg - Arte e Ciência. São Paulo, 1995, pp. 40-43.

LIMA, Mônica Rodrigues de. Schenberg e o concretismo de Waldemar Cordeiro. In CENTRO MARIOSHCNBERG DE DOCUMENTAÇÃO DA PESQUISA EM ARTES. Documentação: arte e ciência. (coord. Elza Ajzenberg). São Paulo: Centro Mario Schenberg/ECA-USP, 1994.

MAIA, Dulce. Jorge Mautner e Dulce Maia. In SCHENBERG, Mario. Mario Schenberg: Entre-Vistas. São Paulo: Perspectiva, 1984.

OITICICA, Hélio. Situação da Vanguarda no Brasil (Propostas 66). In FERREIRA, Glória (org.). Crítica de arte no Brasil: temáticas contemporâneas. Rio de Janeiro: Funarte, 2006.

Esquema Geral da Nova Objetividade. In FERREIRA, Glória; COTRIM, Cecília (seleção e comentários). Escritos de artistas: anos 60/70. Tradução de Pedro Süssekind. et al. - 2. Ed. - Rio de Janeiro: Jorge Zahar Ed., 2009.

OLIVEIRA, Alecsandra Matias. Schenberg: Crítica e Criação. São Paulo: EDUSP, 2011.

OLIVEIRA, Alecsandra Matias de. Waldomiro de Deus por Mario Schenberg. Pesquisa em Debate, edição 7, v. 4, n. 2, Jul/dez de 2007. ISSN 1808-978X.

OLIVEIRA, Rita Alves. Bienal de São Paulo - Impacto na Cultura Brasileira. São Paulo Perspectiva. Vol. 15 no. 3 São Paulo July/Sept. 2001.

PACHECO, Anésia. Mario Schenberg: crítico de arte. REVISTA USP, São Paulo, n. 52, p. 113-114, dezembro/fevereiro 2001-2002.

PEDROSA, Mário. Política das Artes, (org.) Otília Beatriz Fiori Arantes. São Paulo: EDUSP, 1995.

PEDROSA, Mário. Mundo, Homem, Arte em crise. (Org. Aracy Amaral). São Paulo: Perspectiva, 1995. 
PEDROSA, Mário. A Bienal de Cá para Lá. In Mundo, Homem, Arte em crise. (Org. Aracy Amaral). São Paulo: Perspectiva, 1995.

PEDROSA, Mário. “A Bienal de cá para lá”. In Otília Arantes (org.) Política das Artes. São Paulo: EDUSP, 1995.

PEDROSA, Mário. Depoimento sobre o MAM. In: ARANTES, Otilia (Org.). Mário Pedrosa/política das artes. São Paulo: Edusp, 1995. p. 299-308.

PENTEADO, Yolanda. Tudo em cor de rosa. Rio de Janeiro: Nova Fronteira: 1976.

PISMEL, Ana Paula Cattai. Schenberg e vanguardas: Crítica como parceria. In: VIII Congresso de Estética e História da Arte, Desenhos da Pesquisa: Novas Metodologias da Pesquisa em Arte. São Paulo: Museu de Arte Contemporânea da Universidade de São Paulo, 2012. v.1. p.279 - 288.

Projeto de Lei No 248 de 1947. Institui a Fundação Paulista de Pesquisas Científicas. In: MOTOYAMA, S.; Hamburger, A.I.; NAGAMINI, M. (Orgs.) Para uma história da FAPESP: marcos documentais. São Paulo: FAPESP, 1999. p. 69-73.

SCHENBERG, Mario. Depoimento. In AJZENBERG, Elza. Schenberg - Arte e Ciência. São Paulo: ECA/USP, 1995, p. 142.

. Pensando a Física. São Paulo: Nova Stella Editorial, 1990.

. Pensando a Arte, São Paulo: Nova Stella, 1988.

1985.

Diálogos com Mario Schenberg. São Paulo: Nova Stella Editorial,

. Mario Schenberg: Entre-Vistas. São Paulo: Perspectiva, 1984.

. Arte e Tecnologia. In GULLAR, Ferreira \& PEDROSA, Mário. Arte

brasileira hoje: situação e perspectivas. Rio de Janeiro: Paz e Terra, 1973.

1991.

Formação da Mentalidade Científica. In Estudos Avançados, 12(5),

- Entrevista com Mario Schenberg. (Publicado originalmente na Revista Trans/Form/Ação, v. 3, p. 6-62, 1980). In Trans/Form/Ação. Marília, v.34, 2011. Edição Especial.

Currículo artístico de Mario Schenberg. Texto depositado no Centro Mario Schenberg de Documentação da Pesquisa em Arte - ECA/USP.

. João Parisi Filho. In. AJZENBERG, Elza (org.). Arte e Ciência Schenberg: Textos Críticos (Diálogos II). São Paulo: ECA/USP, PM Studium Comunicação e Design, 2015. 
de São Paulo, edição de 10/12/1978). Disponível em:

http://www.sbfisica.org.br/rbef/pdf/vol01a18.pd Acesso em 16/Fev/2012.

SILVA, Luiz Hildebrando Pereira da. Depoimento. In MAMBURGUER, Amélia Império et al (organização e edição). FAPESP 40 anos abrindo fronteiras. São Paulo: Editora da Universidade de São Paulo, 2005.

SOARES, Jô. O Livro de Jô: uma biografia desautorizada. $1^{\text {a }}$ edição. São Paulo: Companhia das Letras, 2017.

\section{Relatórios}

CENTRO MARIO SCHENBERG DE DOCUMENTAÇÃO DA PESQUISA EM ARTES.

Documentação: arte e ciência. (coord. Elza Ajzenberg). São Paulo: Centro Mario Schenberg/ECA-USP, 1994.

\section{Jornais}

AMARAL, Aracy. Terminada a Seleção da Bienal. A Gazeta, São Paulo (capital), 18/05/1965.

AMARAL, Aracy. Revisão da VIII Bienal. O Estado de São Paulo, 11/12/1965.

ALMEIDA, Paulo Mendes de. A próxima Bienal. O Estado de São Paulo, São Paulo (capital), 26/06/1965.

AYALA, Walmir. A Bienal em Questão. Jornal do Brasil (Rio de Janeiro), 27/09/1969.

AYALA, Walmir. Júris, pra quê?, Jornal do Comércio (Rio de Janeiro), 14/10/1969

BARATA, Mário. Aspectos Organizativos da Bienal. Jornal do Comércio (Rio de Janeiro), 12/10/1969

D’HORTA, Arnaldo Pedroso. Ainda a Bienal, Jornal da Tarde (São Paulo), 22/10/1969.

GULLAR, Ferreira. Não objeto prêmio da Bienal - Lygia Clark. Jornal do Brasil, 16 e 17/09/1961.

JORDÂO, Vera Pacheco. Os críticos e a Bienal. O Globo (Estado da Guanabara), 17/08/1965.

MAURÍCIO, Jayme. Bienal: eleitos dos artistas. Correio da Manhã, 06/06/67.

MORAIS, Frederico. Mesa redonda e Protesto. Diário de Notícias (Rio de Janeiro) em 03/10/1969 
PACHECI, Ver. Os críticos e a Bienal. O Globo (Estado da Guanabara), 17/08/1965.

PACOTE, E. Três horas de debates sobre a obra de Volpi no Museu de Arte Moderna. Folha da Noite, São Paulo (capital) 18/06/1956.

LUVTEN. Jos. Mario Schenberg, amigo dos artistas. A Gazeta. São Paulo, 10/06/1972, p. 9.

SCHENBERG, Mario. Caminhos da Arte de Hoje, Jornal do Brasil (Rio de Janeiro),27/09/1969.

SCHENBERG, Mario. Jornal Folhetim, 24 de julho de 1977.

ZANINI, Ivo. Indicado o Júri da VIII Bienal. Folha Ilustrada (São Paulo - Capital). 27/04/1965.

Artistas a favor do crítico, s/p, s/d, sem identificação de jornal.

AIAP e ABCA recusam convite da Bienal. Folha de São Paulo, 01 de fevereiro de 1969.

Ciência \& Arte: X Bienal de São Paulo. Diário Popular, 19/10/1969.

Cientistas e humanistas na Bienal de Ciências. Folha Ilustrada, 11/04/1969.

Críticos de Arte vão debater reformulação das bienais. Nota enviada à imprensa, documento não datado. Arquivo Histórico Wanda Svevo, Fundação Bienal.

Correio Paulistano, São Paulo (capital), 10/12/1966.

Diário de Notícias, 15/07/1956.

Herdeiro de Einstein ou de simples bandido? Última Hora, terça-feira, 24/11/1964, p. 11 .

IPM's condenados. Última Hora, RJ, 25/03/1965.

Jovem remeteu 15 obras para a Bienal: as 15 foram aceitas. Notícias Populares, São Paulo (Capital), 01/07/1965.

Júri já escolheu artistas brasileiros para a Bienal Internacional de Artes. Nota divulgada à imprensa. Documento datilografado, datado de 11/09/1970. Arquivo Histórico Wanda Svevo, Fundação Bienal.

Júri da $\mathbf{X}$ Bienal convida vinte e cinco artistas, nota divulgada à imprensa pela Fundação Bienal, em 28 de maio de 1969. Arquivo Histórico Wanda Svevo, Fundação Bienal.

Mario Schenberg. Jornal Folhetim, 24 de julho de 1977. 
Mario Schenberg. Transcrição de sua intervenção na Mesa Redonda de 1971. Documento não datado. Arquivo Histórico Wanda Svevo, Fundação Bienal.

O corte foi duro, registrado o maior índice de recusa de todas as bienais: $80 \%$ dos inscritos foram recusados. Correio da Manhã (Estado da Guanabara), 19/05/1965. O Estado de São Paulo. São Paulo (capital) 10/05/1956.

Os primeiros prêmios da VIII Bienal. O Globo (Estado da Guanabara), 01/08/1965. Pintura, Desenho e Opiniões. Correio Paulistano, São Paulo (capital), 22/12/1961. Programação da Mesa Redonda de Críticos de Arte - X Bienal. Documento não datado. Arquivo Histórico Wanda Svevo, Fundação Bienal.

Pré-Bienal começa no dia 12 com artistas de 21 estados. Nota divulgada à imprensa, datilografada, datada de 3/09/1970. Arquivo Histórico Wanda Svevo, Fundação Bienal.

Recomendações da Mesa Redonda de críticos de arte internacionais, não datado, com duas páginas. Arquivo Histórico Wanda Svevo, Fundação Bienal.

Regulamento da Pré-Bienal de São Paulo. Documento datilografado, datado de 20 de janeiro de 1970. Arquivo Histórico Wanda Svevo, Fundação Bienal.

Regimento Interno do evento. Documento não datado. Arquivo Histórico Wanda Svevo, Fundação Bienal.

Relatório das Atividades em 1971. Documento datilografado, datado do mês de janeiro de 1972. Arquivo Histórico Wanda Svevo, Fundação Bienal.

Resultado Integral da Votação para Júri da V Bienal, Crítica de São Paulo (capital), 06/05/1959.

Schenberg em Vez de Milliet. Correio da Manhã (Estado da Guanabara). 07/05/1965.

Schenberg fica. Correio da Manhã, 06/06/67.

Schenberg foi para o congresso no Japão. Última Hora - 27/09/1965 - segunda-feira.

S. Paulo abrigará Bienal de Ciência. O Estado de São Paulo, 02/06/1967.

São Paulo inaugura hoje a VIII Bienal. A Gazeta - São Paulo (Capital), 04/08/1965.

STM dá Habeas de Schenberg e Pery Faz novas denúncias. Correio da Manhã, 25/3/1965.

Última Hora, $2^{\text {a }}$ edição, São Paulo, 25 de março de 1965 (capa).

Teses e dissertações 
AJZENBERG, Elza. Exercícios Estéticos da Liberdade. São Paulo: ECA USP, 1989 (tese de livre docência).

LOPES, Polyana Canhête. MAM-Bienal-MAC: processos de ruptura. São Paulo: Universidade de São Paulo, Programa Interunidades de Pós-Graduação em Estética e História da Arte, 2007. (dissertação de mestrado).

MANTOAN, Marcos José. Yolanda Penteado: gestão dedicada à arte moderna. São Paulo, Universidade de São Paulo, Programa de Pós-Graduação em Artes Visuais Escola de Comunicações e Artes, 2015. (tese de doutorado).

MOURA, Luanda de. Mecenato: Atores, Objetos e Práticas. Rio de Janeiro: Fundação Getúlio Vargas/Centro de Pesquisa e documento de História Contemporânea do Brasil, 2012 (dissertação apresentada ao Programa de Pós-Graduação em História, Política e Bens Culturais).

PISMEL, Ana Paula Cattai. Schenberg: em busca de um Novo Humanismo. São Paulo: Programa de Pós-Graduação Interunidades em Estética e História da Arte, Universidade de São Paulo, 2013 (dissertação de mestrado).

\section{Catálogos}

AGUILAR, José Roberto. O mundo de Mario Schenberg. São Paulo: Casa das Rosas, 1996.

AJZENBERG, Elza (org.). Ciccillo: Acervo MAC-USP - Homenagem a Francisco Matarazzo Sobrinho, Ciccillo. São Paulo, Museu de Arte Contemporânea da Universidade de São Paulo, 2006.

AJZENBERG, Elza (org.). MAC Virtual: Prêmios Bienais Acervo MAC USP / São Paulo: Museu de Arte Contemporânea da Universidade de São Paulo, 2004.

FUNDAÇÃO BIENAL DE SÃO PAULO. 50 anos Bienal de São Paulo: 1951-2001. (catálogo de exposição) São Paulo: Fundação, 2001.

XI Bienal. (catálogo de exposição). São Paulo: Fundação Bienal, 1971.

. X Bienal. (catálogo de exposição) São Paulo: Fundação Bienal, 1969.

IX Bienal. (catálogo de exposição) São Paulo: Fundação Bienal, 1967.

VIII Bienal. (catálogo de exposição) São Paulo: Fundação Bienal, 1965.

VI Bienal. (catálogo de exposição) São Paulo: Fundação Bienal, 1961.

II Bienal. (catálogo de exposição) São Paulo: Museu de Arte Moderna de São Paulo, 1953. 
SCHENBERG, Mario. Alfredo Volpi. In FUNDAÇÃO BIENAL, VI Bienal. . (catálogo de exposição) São Paulo: Fundação Bienal, 1961.

SHCNBERG, Mario. Novos Valores, in FUNDAÇÃO BIENAL. X Bienal. (catálogo de exposição) São Paulo: Museu de Arte Moderna de São Paulo, 1969.

\section{Cartas e documentos}

Carta de Mário Pedrosa a Mario Schenberg, de 02 de fevereiro de 1961. Arquivo Histórico Wanda Svevo, Fundação Bienal.

Carta de Maurício Nogueira Lima (Presidente da AIAP) a Francisco Matarazzo Sobrinho, datada de 16 de maio de 1969. Arquivo Histórico Wanda Svevo, Fundação Bienal.

Carta de Mário Pedrosa a Theon Spanudis, de 22 de dezembro de 1960.

Carta de Walter Zanini à Diná Coelho Lopes, de 30 de abril de 1961.

Carta de Quirino Campofiorito ( ${ }^{\circ}$ Vice-Presidente da AICA) e Mirian Quiaverini (Presidente da AIAP) a Francisco Matarazzo Sobrinho, datada de 31 de Janeiro de 1969.

Carta de Francisco Matarazzo Sobrinho a Maurício Nogueira Lima (Presidente da AIAP), datada de 2 de maio de 1969.

Carta de Francisco Matarazzo Sobrinho a Maurício Nogueira Lima (Presidente da AIAP), datada de 2 de maio de 1969. Arquivo Histórico Wanda Svevo, Fundação Bienal.

Carta de Maurício Nogueira Lima (Presidente da AIAP) a Francisco Matarazzo Sobrinho, datada de 16 de maio de 1969, p. 1 (foi mantida a grafia original). Arquivo Histórico Wanda Svevo, Fundação Bienal.

Carta de Mário Pedrosa a Mario Schenberg, de 02 de fevereiro de 1961.

Carta de Mário Pedrosa a Theon Spanudis, de 22 de dezembro de 1960 (Arquivo Histórico Wanda Svevo).

Júri da X Bienal convida vinte e cinco artistas. Arquivo Histórico Wanda Svevo, Fundação Bienal.

Telegrama de Edyla Mangabeira Unger à Fundação Bienal, datado de 25 de Setembro de 1969.

Telegrama assinado pelos críticos: Pedro Manuel Gismondi, Antônio Bento, Aracy Amaral, Maria Eugênia Franco, José Roberto Teixeira Leite, Theon Spanudis, Waldemar Cordeiro e Walter Zanini à Fundação Bienal, datado de 25 de setembro de 1969. Arquivo Histórico Wanda Svevo, Fundação Bienal. 
Carta a J. Carvalho, datada de 24/08/1961, assinada por Francisco Matarazzo Sobrinho solicitando o empréstimo das obras para a sala especial. Arquivo Histórico Wanda Svevo/Fundação Bienal

Telegrama datado de 25 de setembro de 1969. Arquivo Histórico Wanda Svevo, Fundação Bienal.

Mesa Redonda de Críticos de Arte - X Bienal. Documento não datado. Arquivo Histórico Wanda Svevo, Fundação Bienal.

Mario Schenberg. Transcrição de sua intervenção na Mesa Redonda de 1971. Documento não datado, p. 7. Arquivo Histórico Wanda Svevo, Fundação Bienal.

Recomendações da Mesa Redonda de críticos de arte internacionais, não datado, com duas páginas. Arquivo Histórico Wanda Svevo, Fundação Bienal.

Mario Schenberg, documento datilografado, não datado, 7 páginas. Arquivo Histórico Wanda Svevo, Fundação Bienal.

Carta enviada por Mario Schenberg à Ana Clara Guerrini Schenberg. Cerca de 1964. Fonte: Arquivo pessoal de Ana Clara Schenberg.

Carta de Luís Fernando Rodrigues Alves (Diretor Secretário) a Mario Schenberg, datada de 19 de dezembro de 1967. Arquivo Histórico Wanda Svevo/Fundação Bienal.

Proposta para a Bienal de Física de 1969 da Bienal de Ciência e Humanismo. Documento datilografado, datado de 23 de abril de 1968. Arquivo Histórico Wanda Svevo/Fundação Bienal.

Carta de agradecimento de Sérgio Mário Pasquali, presidente do Projeto Rondon, pelo seminário "Conhecimento Científico e a Sociedade" realizado no Instituto de Física da UFBA, entre 11 e 14 de setembro de 1979. Brasília/DF; s/d.; 1d; 1p.; assinado; impr/dat.; original.

Carta de agradecimento Sérgio Mário Pasquali, presidente do Projeto Rondon, pelo seminário "Conhecimento Científico e a Sociedade" realizado no Instituto de Física da UFBA, entre 18 e 20 de outubro de 1979. Brasília/DF; s/d.; 1d; 1p.; s/assinatura; impr/dat.; original.

Prontuário de Mario Schenberg, $\mathrm{n}^{\circ}$ 89.583. Arquivo Geral do Departamento de Ordem e Social e Política - DOPS. Arquivo do Estado de São Paulo.

\section{Atas}

Ata da reunião do júri de seleção, dia 04/07/1967. Arquivo Histórico Wanda Svevo, Fundação Bienal. 
Ata da reunião preparatória da II Bienal de Ciência e Humanismo. Documento datilografado, 04/02/1969. Arquivo Histórico Wanda Svevo/Fundação Bienal.

Ata da primeira reunião da Comissão Coordenadora da II Bienal de Ciência e Humanismo. Documento datilografado, 13/02/1969. Arquivo Histórico Wanda Svevo/Fundação Bienal.

Ata do Júri de Seleção, dia 26/06/1969. Arquivo Histórico Wanda Svevo, Fundação Bienal.

Ata do Júri de Seleção, dia 07/07/1969. Arquivo Histórico Wanda Svevo, Fundação Bienal.

Ata da apuração de apuração da eleição do representante dos artistas no Júri de Seleção da XI Bienal. Documento manuscrito, datado de 31 de agosto de 1970. Arquivo Histórico Wanda Svevo, Fundação Bienal.

\section{Sites}

ASSOCIAÇÂO BRASILEIRA DE CRÌTICOS DE ARTE. Histórico. Disponível em: http://abca.art.br/historico/ Acesso em 23/02/2018.

ASSEMBLEIA LEGISTATIVA DO ESTADO DE SÃO PAULO. Constituição de 1947. Disponível em: http://www.al.sp.gov.br/leis/constituicoes/constituicoesanteriores/constituicao-estadual-1947/ Acesso em: 28/02/2017.

ASSEMBLÉIA LEGISTATIVA DO ESTADO DE SÃO PAULO. LEI N. 5.918, DE 18 DE OUTUBRO DE 1960. Disponível em:

http://www.al.sp.gov.br/repositorio/legislacao/lei/1960/lei-5918-18.10.1960.html Acesso em: 28/02/2017.

CENTRO MARIO SHCENBERG DE DOCUMENTAÇÃO DA PESQUISA EM ARTES. Disponível em:

http:/www.eca.usp.br/nucleos/cms/index.php?option=com content\&view=section\&id=2\&Itemid=3 Acessado em 03/Jul/2012.

DIÁRIO OFICIAL DA UNIÃO. ATO Complementar $\mathbf{n}^{\mathbf{0}} \mathbf{7 5}$, de 21 de outubro de 1969, p. 8930. Disponível em: http://www.planalto.gov.br/ccivil_03/ACP/acp-7569.htm Acesso em: 20/02/20013.

FAPESP. Linha do Tempo. Disponível em: http://www.bv.fapesp.br/linha-dotempo/212/artigo-123-constituicao-1947/ Acesso em: 28/02/2017.

FILHO, Antônio Gonçalves. Schenberg Pensa a Arte. Folha de São Paulo, 19/mar/1988, Livros, p. D - 4. Disponível em http://acervo.folha.com.br/fsp/1988/03/19/349//4147898 Acesso em 20/Jan/2012. 
FUNDAÇÃO BIENAL. Ciência e Humanismo. Disponível em:

http://www.bienal.org.br/FBSP/pt/AHWS/blog/post.aspx?post=111 Acesso em 25/06/2013.

FUNDAÇÃO BIENAL. Hoje e Antes: Um paralelo entre imagens das obras na mostra $30 \times$ Bienal e seus primeiros registros nas Bienais passadas. 02/out./2013. Disponível em: http://www.bienal.org.br/post/263 Acesso em 12/06/2018.

FUndaÇÃo BIEnAl de SÃo PAUlo. $7^{\text {a }}$ Bienal de São Paulo. Disponível em: http://www.bienal.org.br/exposicoes/7bienal/fotos/3871 Acesso em: 11/06/2018.

FUndAÇÃo BIEnAl de SÃO PAUlO. $8^{\mathbf{a}}$ Bienal de São Paulo. Disponível em: http://www.bienal.org.br/exposicoes/8bienal/fotos/3880 Acesso em: 12/06/2018.

JOHN SIMON GUGGENHEIM MEMORIAL FONDATION. Mario Schenberg fellow. Disponível em: https://www.gf.org/fellows/all-fellows/mario-schenberg/ Acesso em 25/02/2018.

LA BIENNALE DI VENEZIA. History. Disponível em http://www.labiennale.org/en/history/ Acesso em 21/02/2018.

PRESIDÊNCIA DA REPÚBLICA. ATO Complementar $\mathbf{n}^{\mathbf{0}} \mathbf{7 5}$, de 21 de outubro de 1969, Diário Oficial da União, p. 8930. Disponível em: http://www.planalto.gov.br/ccivil_03/ACP/acp-75-69.htm Acesso em: 20/02/2016.

25. Esposizione Biennale Internazionale d'Arte, Archivo Storico Delle Arti Contemporanee/La Biennale di Venezia. Disponível em:

http://asac.labiennale.org/it/passpres/artivisive/annali.php? $\mathrm{m}=228 \mathrm{\& s}=4580 \mathrm{\& c}=\mathrm{ea}$

Acesso em 21/02/2018.

\section{Entrevistas realizadas}

SCHENBERG, Ana Clara Guerrini. Entrevista concedida a Ana Paula Cattai Pismel. São Paulo, 11 mai. 2018. 2 arquivos .mp3 (40'41')'. [A entrevista encontra-se depositada no Centro Mario Schenberg de Documentação da Pesquisa em Arte ECA/USP]

BONOMI, Maria. Entrevista concedida a Ana Paula Cattai Pismel. São Paulo, 16 mai. 2018. 4 arquivos .mp3 (1h46'15'). [A entrevista encontra-se depositada no Centro Mario Schenberg de Documentação da Pesquisa em Arte - ECA/USP]

TORRES, Caciporé. Entrevista concedida a Ana Paula Cattai Pismel. São Paulo, 08 mai. 2018. 1 arquivo .mp3 (16'39''). [A entrevista encontra-se depositada no Centro Mario Schenberg de Documentação da Pesquisa em Arte - ECA/USP]

AGUILAR, José Roberto. Entrevista concedida a Ana Paula Cattai Pismel. São Paulo, 10 mai. 2018. 1 arquivo .mp3 (21'). [A entrevista encontra-se depositada no Centro Mario Schenberg de Documentação da Pesquisa em Arte - ECA/USP] 
MAGALHÃES, Fábio. Entrevista concedida a Ana Paula Cattai Pismel. São Paulo, 05 abr. 2018. 12 arquivos .MOV (1h52'22''). [A entrevista encontra-se depositada no Centro Mario Schenberg de Documentação da Pesquisa em Arte - ECA/USP]

\section{Entrevistas}

SCHENBERG, Mário. Mário Schenberg (depoimento, 1978). Rio de Janeiro, CPDOC, 2010. 93p.

\section{Arquivos}

Arquivo do Centro Mario Schenberg de Documentação da Pesquisa em Artes. Universidade de São Paulo

Av. Prof. Lúcio Martins Rodrigues, 433, bloco B9, sala 9

05508-900 - São Paulo - SP - Brasil

\section{Arquivo Histórico Wanda Svevo}

Fundação Bienal de São Paulo

Pavilhão Ciccillo Matarazzo

Parque do Ibirapuera - Portão 3

04094-000

São Paulo - SP - Brasil

\section{Arquivos do DEOPS-SP}

Arquivo Público do Estado de São Paulo

Avenida Cruzeiro do Sul, 1.777

Santana - São Paulo - SP - Brasil

Acervo Histórico do Instituto de Física da USP

Universidade de São Paulo

Rua do Matão, 1371

05508-090 - São Paulo - SP - Brasil

ASAC - Archivio Storico delle Arti Contemporanee

Fondazione La Biennale di Venezia

Biblioteca della Biennale

Calle Paludo S. Antonio - 30122 Venezia

http://www.labiennale.org/it/asac 
Gerais

Livros, Capítulos e Artigos

ADUSP. O livro negro da USP: controle ideológico na Universidade (1964-1978).

São Paulo: Adusp, 2004.

AJZENBERG, Elza. Grupo Santa Helena. 1920, Rio de Janeiro, v.III, n. 4, out. 2008. Disponível em: 〈http://www.dezenovevinte.net/artistas/artistas_gsh.htm> Acesso em 02/03/2018

ALVARADO, Daisy Valle Machado Peccinini de. Figurações Brasil Anos 60:

Neofigurações Fantásticas e Neosurrealismo, Novo Realismo e Nova

Objetividade. São Paulo: Itaú Cultural/Edusp, 1999.

AMARAL, Aracy. Arte Pra Quê? A Preocupação Social na Arte Brasileira 19301970. São Paulo: Nobel, 1984.

AMARAL, Aracy. Yolanda Penteado e o MAC. Vogue Brasil, edição extra, especial sobre Yolanda Penteado, 1984.

AMARAL, Aracy. Arte no Brasil. In CENTRO DE ESTUDOS DE ARTE

CONTEMPORÂNEA. Arte em Revista, em 1979, ano I, nº. 2, p. 29.

ANDRADE, G. E. e ARDIES, J. A arte naïf no Brasil. São Paulo: Empresa das Artes, 1998.

ANDRADE, Mário de. O Movimento Modernista. In: Aspectos da Literatura brasileira. $6^{\text {a }}$ ed. Belo Horizonte: Itatiaia, 2002, p. 266.

ARCHER, Michael. Arte Contemporânea. São Paulo: Martins Fontes, 2008, 2a Edição.

ARGAN, Giulio Carlo. As Fontes da Arte Moderna (trad. Rodrigo Naves). Novos Estudos (18), São Paulo, CEBRAP, set. 1987.

ARANTES, Otília Beatriz Fiori. Mário Pedrosa Itinerário crítico. São Paulo, Cosac Naify, 2004.

ARANTES, Otília Beatriz Fiori. Depois das Vanguardas, in Arte em Revista, São Paulo, 5 (7), 1983, pp. 5-20.

BARATA, Mário. Opinião 65: Artes Visuais de Vanguarda (Seminário Propostas 66). Arte em Revista (nº 2), São Paulo, CEAC, Maio-Agosto, 1979, p. 35- 6. 
BERGSON, Henri. Ensaio sobre os Dados Imediatos da Consciência, Lisboa, Edições 70.

BLACKBURN, Simon. (Ed.). Dicionário Oxford de Filosofia. Rio de Janeiro: Jorge Zahar Editor, 1997.

BOAVENTURA, Maria Eugenia. A Semana de Arte Moderna e a crítica contemporânea. Cadernos de Pós-Graduação da UNICAMP, v. 8, p. 19-24, 2006. Disponível em: https://slidex.tips/download/a-semana-de-arte-moderna-e-a-criticacontemporanea-maria-eugenia-boaventura Acesso em: 01/03/2018

BONOMI, Maria. Depoimento Maria Bonomi. In Revista da Biblioteca Mário de Andrade, - O Medo, São Paulo, nº70, 2016, pp. 148-163.

BRITO, Ronaldo. Neoconcretismo: Vértice e ruptura do projeto construtivo brasileiro. São Paulo: Cosac \& Naify, 1999.

CHICÓ, Mário Tavares. Arte naïf. In Dicionário de pintura universal. Lisboa: Editorial Estúdios Cor, 1973.

COHEN, Marilene. Albert Einstein. Col. Personagens que marcaram época. São Paulo: Globo, 2007.

D'AMBROSIO, Oscar. Os pincéis de Deus: vida e obra de do pintor naïf Waldomiro de Deus. São Paulo: Editora UNESP, 1999.

DUARTE, Paulo Sérgio. Anos 60: transformações da arte no Brasil. Rio de Janeiro: Campos Gerais, 1998. p.224.

ECO, Umberto. Entrevista com Umberto Eco. In ECO, Umberto. Obra aberta: formas e indeterminação nas poéticas contemporâneas. Tradução: Giovanni Catulo et al. $10^{\mathrm{a}}$ edição. São Paulo: Perspectiva, 2015.

ECO, Umberto. Como se faz uma tese. 23a edição. São Paulo: Perspectiva, 2010.

EINSTEIN, Albert. Como vejo o mundo. Tradução de H. P. de Andrade. Rio de Janeiro: Editora Nova Fronteira, 1981.

FABRIS, Anateresa. Modernidade e Modernismo no Brasil. Porto Alegre: Zoulk, 2010.

FERREIRA, Glória \& COTRIM, Cecília (seleção e comentários). Escritos de artistas: anos 60/70. Tradução de Pedro Süssekind... et al. - 2. Ed. - Rio de Janeiro: Jorge Zahar Ed., 2009.

FERREIRA, Glória. Crítica de arte no Brasil: temáticas contemporâneas. Rio de Janeiro: Funarte, 2006. 
FERREIRA, Glória; COTRIM, Cecília (seleção e comentários). Escritos de artistas: anos 60/70. Tradução de Pedro Süssekind... et al. - 2. Ed. - Rio de Janeiro: Jorge Zahar Ed., 2009.

GIBBS, G. Análise de dados qualitativos. Porto Alegre: Bookman, 2009.

GOMBRICH, Ernest. História da Arte. Rio de Janeiro: LTC, 2009.

GULLAR, Ferreira. Opinião 65 (Revista Civilização Brasileira). In Arte em Revista $\left(n^{\circ}\right.$ 2), São Paulo, CEAC, Maio-Agosto, 1979.

HUYGHE, René. Dialogue avec le visible. Paris: Flammarion, 1955.

JUNG, Carl. Tipos Psicológicos. Rio de Janeiro: Zahar Editores, 1974.

JUNG, Carl. Memória, Sonhos, Reflexões. Rio de Janeiro: Nova Fronteira, 1970.

KANDINSKY, Wassily. Do Espiritual na Arte, e na pintura em particular. São Paulo: Martins Fontes, 1996.

LEITE, José Roberto Teixeira. Dicionário crítico da pintura no Brasil. Rio de Janeiro: Artlivre, 1988. p.386.

MARQUES, Maria Eduarda. Mira Schendel. São Paulo: Cosac \& Naify Edições 2001.

MARTON, Scarlett. A irrecusável busca de sentido: autobiografia intelectual. Cotia, SP: Ateliê Editorial; Ijuí, RS: Editora UNIJUÍ, 2004.

MOTTA, Rodrigo P. Sá. As universidades e o regime militar: cultura política brasileira e modernização autoritária. 1ª edição. Rio de Janeiro: Zahar, 2014.

PEDROSA, Mário. Opinião... Opinião... Opinião... in Mundo, Homem, Arte em crise. São Paulo: Perspectiva, 1975.

POINCARÈ, Henri. Valor da ciência. (tradução Maria Helena Franco Martins ; revisão técnica Ildeu de Castro Moreira) Rio de Janeiro: Contraponto, 1995.

PONTUAL, Roberto. Dicionário Brasileiro de Artes Plásticas. Rio de Janeiro: Ed. Civilização Brasileira, 1969. p.406.

READ, Herbert. Arte e Alienação. Rio de Janeiro: Zahar Editores, 1968.

RESTANY, Pierre. Os Novos Realistas. São Paulo: Perspectiva, 1979.

ROCCO, Renata Dias Ferrareto. Danilo Di Prete no Brasil: sobre relatos de vida, a criação da Bienal de São Paulo e o arquivo da família. In Escrita da história e (re)construção das memórias: arte e arquivos em debate. FREIRE, Cristina (org.) Congresso Internacional de Estética e História da Arte. São Paulo: Museu de Arte Contemporânea da Universidade de São Paulo, 2016, p.335 - 340. 
SCHWARZ, Roberto. Cultura e Política, 1964-69, in O Pai de Família e outros estudos. Rio de Janeiro: Paz e Terra, 1978.

SEVERINO, Joaquim Antônio. Metodologia do Trabalho Científico. $23^{\mathrm{a}}$ edição revista e atualizada. São Paulo: Cortez, 2007.

\section{Catálogos}

AMARAL, Aracy. A visão do colecionador. In Volpi: pequenos formatos. São Paulo: Museu de Arte Moderna de São Paulo, 2016.

AMARAL, Aracy A. (org.) Projeto construtivo na arte brasileira: 1950-1962. (catálogo de exposição) Rio de Janeiro: Museu de Arte Moderna; são Paulo, Pinacoteca do Estado, 1977.

Jornais

CORDEIRO, Waldemar. Todos Atentos. Artes: Ano I, nº 3, jan. 1966.

VIEIRA, José Geraldo. Aula Maior. Artes: Ano I, nº 3, jan. 1966.

Folha registrou trajetória de FHC, da USP à Presidência. Jornal Folha de São Paulo. 18 de junho de 2011.

Teses e dissertações

D'AMBROSIO, Oscar Alejandro Fabian. Um mergulho no Brasil Naif: a Bienal Naifs do Brasil do SESC Piracicaba: 1992 a 2010. 2013. 204 f. Tese (Doutorado em Educação, Arte e História) - Universidade Presbiteriana Mackenzie, São Paulo, 2013.

PELEGRINI, Ana Claudia Salvato. A Iconografia de Massa nas Artes Plásticas: Brasil Anos 60. Dissertação de Mestrado. Programa Interunidades em Estética e História da Arte da Universidade de São Paulo, 2006.

CLEMENTE, José Eduardo Ferraz. Ciência e política durante a ditadura militar: o caso da comunidade brasileira de físicos (1964-1979). Salvador: Universidade Federal da Bahia, Instituto de Física, 2005. (dissertação de Mestrado).

OLIVEIRA, Liliana H. T. Mendes de. A Bienal Pop. Dissertação (Mestrado em História) - Instituto de Filosofia e Ciências Humanas, Universidade de Campinas, Campina, 1993. 


\section{Catálogos}

AJZENBERG, Elza Maria (org.). Operários na Paulista: MAC USP e artistas artesãos. Apresentação Horácio Lafer Piva, Elza Maria Ajzenberg; introdução Daisy Valle Machado Peccinini de Alvarado. São Paulo: MAC, 2002. 92 p., il. p\&b color.

CENTRO CULTURAL BANCO DO BRASIL. Opinião 65 - 30 Anos. (catálogo de exposição) Rio de Janeiro: Centro Cultural Banco do Brasil, 1995.

GALERIA DE ARTE BANERJ. Ciclo de Exposições sobre Arte no Rio de Janeiro: 5. Opinião 65 (catálogo de exposição) Rio de Janeiro: Galeria de Arte Banerj, 1985.

MUSEU DE ARTE MODERNA DO RIO DE JANEIRO. Opinião 66 (catálogo de exposição) Rio de Janeiro: MAM, 1966.

MUSEU DE ARTE MODERNA - RJ. Opinião 66. (folheto de exposição). São Paulo, 1966. É interessante notar que, dessa vez, todos os artistas brasileiros eram cariocas ou residiam no Rio de Janeiro.

WARHOL, Andy. Catálogo de exposição. Andy Warhol: Mr. América. Catálogo de exposição. São Paulo: Pinacoteca do Estado, 2010.

Vídeos

AGUILAR, José Roberto; MEIRELLES, Lucila; MARTIRANI, Pichi. Julieta é Bárbara. 2007, (25'). Disponível em: https://www.youtube.com/watch?v=MxvNadhGpk Acesso em: 03 mar. 2017.

Sites

Acervo MAM-SP. Disponível em: http://mam.org.br/acervo/322-bonomi-maria/ Acesso em: 12/06/2018.

Arquivos guardam cadernetas de Prestes. Folha de São Paulo, 08/04/2001. Disponível em: http://www1.folha.uol.com.br/fsp/brasil/fc0804200118.htm Acesso em: $13 / 11 / 2917$.

ALVARADO, Daisy Valle Machado Peccinini de. Figurações no Brasil: anos 60. In: Projeto Visitando o MAC na Web. Disponível em http://www.mac.usp.br/mac/templates/projetos/seculoxx/modulo4/abertura/index.html Acesso em: 10/Nov/2011.

CARTA CAPITAL. O esplendor proletário e o Grupo Santa Helena. Disponível em https://www.cartacapital.com.br/revista/902/o-esplendor-proletario (Acesso em 02/03/2018) 
CHIARELLI, Tadeu. Considerações breves sobre a arte contemporânea e o papel das instituições. In Revista Itaú Cultural. Disponível em:

http://www.itaucultural.org.br/impressao.cfm?materia=847 Acesso em 13/Nov/2011.

CHICO da Silva. In: ENCICLOPÉDIA Itaú Cultural de Arte e Cultura Brasileiras. São Paulo: Itaú Cultural, 2018. Disponível em:

$<$ http://enciclopedia.itaucultural.org.br/pessoa9894/chico-da-silva>. Acesso em: 26 de Jun. 2018.

DICIONÁRIO DE ARTISTAS DO BRASIL. Verbete Quissak Júnior. Disponível em http://www.brasilartesenciclopedias.com.br/nacional/quissak_junior.htm\#fotos Acesso em: 12/06/2018.

Exposição revisita obras de Maria Bonomi. Folha de São Paulo - Iluatrada. Disponível em: https://www1.folha.uol.com.br/fsp/ilustrada/45945-exposicao-revisitaobra-de-maria-bonomi.shtml Acesso em: 10/06/2018.

GALERIA LUCIANA BRITO. Artistas: Waldemar Cordeiro. Disponível em: http://www.lucianabritogaleria.com.br Acesso em 05/06/2013.

GRUPO Santa Helena. In: ENCICLOPÉDIA Itaú Cultural de Arte e Cultura Brasileiras. São Paulo: Itaú Cultural, 2018. Disponível em:

<http://enciclopedia.itaucultural.org.br/grupo520054/grupo-santa-helena>. Acesso em: 10 de Jun. 2018. Verbete da Enciclopédia. ISBN: 978-85-7979-060-7

HEITOR dos Prazeres. In: ENCICLOPÉDIA Itaú Cultural de Arte e Cultura Brasileiras. São Paulo: Itaú Cultural, 2018. Disponível em:

<http://enciclopedia.itaucultural.org.br/pessoa10428/heitor-dos-prazeres>. Acesso em: 10 de Jun. 2018. Verbete da Enciclopédia. ISBN: 978-85-7979-060-7.

ITAÚ CULTURAL. Enciclopédia de Artes Visuais Itaú Cultural. Disponível em: www.itaucultural.org.br Acesso em 02/Fev/2013.

INSTITUTO HILDA HIST. Diálogos com Mario Schenberg. Disponível em: https://www.hildahilst.com.br/blog/dialogos-com-mario-schemberg Acesso em 01/05/2017.

INSTITUTO HILDA HIST. Hilda e obra. Disponível em: https://www.hildahilst.com.br/hilda Acesso em 01/05/2017.

ITAÚ CUlTURAL. Ocupação Hilda Hilst. Casa do Sol. Disponível em: http://www.itaucultural.org.br/ocupacao/hilda-hilst/casa-do-sol// Acessp em: $12 / 06 / 2018$.

JOSÉ Antônio da Silva. In: ENCICLOPÉDIA Itaú Cultural de Arte e Cultura Brasileiras. São Paulo: Itaú Cultural, 2018. Disponível em:

<http://enciclopedia.itaucultural.org.br/pessoa2079/jose-antonio-da-silva>. Acesso em: 26 de Jun. 2018. 
JOSÉ ROBERTO AGUILAR. Disponível em: https://joserobertoaguilar.com/ Acesso em 10/06/2018.

MUSEU AFROBRASIL. Reunida ao longo de 50 anos, coleção de Emanoel Araujo é exposta no Museu Afro Brasil. Disponível em:

http://www.museuafrobrasil.org.br/programacao-

cultural/exposicoes/temporarias/detalhe?title $=\% 22 \mathrm{O}+$ que $+\mathrm{os}+\mathrm{olhos}+\mathrm{n} \% \mathrm{C} 3 \% \mathrm{~A} 3 \mathrm{o}+\mathrm{v} \%$ C3\%AA\%2C+o+cora\%C3\%A7\%C3\%A3o+n\%C3\%A3o+sente\%22+-

$+\mathrm{A}+$ arte + de + todo + mundo $\% 3 \mathrm{~A}+50+$ anos + de+viv $\% \mathrm{C} 3 \%$ AAncias Acesso em:

$13 / 02 / 2016$.

UNIVERSIDADE FEDERAL DO ACRE. Coronel Sérgio Mário Pasquali. Disponível em: http://www.ufac.br/site/news/coronel-sergio-mario-pasquali Acesso em $\underline{10 / 06 / 2018 .}$. 


\section{Anexos}

Anexo A - Perfil de Mario Schenberg ${ }^{453}$

Mario Schenberg (Recife PE 1914 - São Paulo SP 1990). Crítico de arte e físico. Transfere-se de Recife, sua cidade natal, para o Rio de Janeiro em 1929, ao finalizar os estudos secundários. Em 1933, em São Paulo, estuda na Escola Politécnica, formando-se engenheiro eletricista dois anos depois. Em 1936, torna-se bacharel em matemática pela Universidade de São Paulo (USP). Publica o primeiro trabalho como físico na revista italiana Il Nuovo Cimento, em 1936. Dois anos mais tarde, viaja a Roma, onde trabalha com o físico Enrico Fermi (1901 - 1954), ganhador do prêmio Nobel. Em 1939, conhece os artistas Di Cavalcanti e Noêmia Mourão, o crítico de cinema Paulo Emílio Salles Gomes (1916 - 1977) e o físico Plínio Sussekind Rocha, em Paris. Quando retorna ao Brasil, frequenta a casa do escritor Oswald de Andrade, onde conhece a artista Teresa D'Amico.

Em 1940, vai aos Estados Unidos como bolsista da Fundação Guggenheim para trabalhar com astrofísica, ao lado de George Gamow (1904 - 1968). No mesmo ano, expõe sua produção fotográfica no Observatório de Yerkes, na Universidade de Chicago. Em 1941, publica estudo sobre evolução estelar com outro futuro prêmio Nobel, o físico Subrahmanyan Chandrasekhar (1910 - 1995), da mesma universidade. Nessa época, inicia seus estudos sobre arte e filosofia oriental. Conhece o escultor russo Ossip Zadkine (1890 - 1967) e o pintor mexicano Rufino Tamayo (1899 - 1991).

No ano seguinte, dá continuidade ao seu trabalho no Departamento de Física da USP e escreve sobre artistas brasileiros - entre eles, Tereza D'Amico, cuja primeira exposição individual, em 1944, Schenberg organiza e fotografa, sendo também responsável pelo texto do catálogo. Por intermédio do escultor Bruno Giorgi e Volpi, conhece o pintor José Pancetti. Frequenta o ateliê de Lasar Segall e de Flávio de Carvalho. Convive com críticos paulistanos, como Lourival Gomes Machado, Sérgio

453 ITAÚ CULTURAL. Enciclopédia de Artes Visuais Itaú Cultural. Disponível em: ww.itaucultural.org.br Acesso em 01/Jul/2016. 
Milliet e Maria Eugenia Franco. Ainda em 1944, com a tese Os Princípios da Mecânica torna-se professor da cadeira de mecânica racional, celeste e superior da USP.

Em 1947, é eleito deputado estadual pelo Partido Comunista, sendo cassado poucos meses após a posse. Em 1948, volta à Europa onde ministra aulas na Universidade Livre de Bruxelas, Bélgica. Quando volta ao Brasil em 1953, torna-se diretor do Departamento de Física da USP até 1961. Nesse mesmo ano, organiza retrospectiva de Volpi na Bienal Internacional de São Paulo, a pedido de Mário Pedrosa. Nessa década, retoma atividades ligadas à crítica de arte sendo eleito o representante dos artistas no júri nacional de seleção da Bienal em 1965, 1967 e 1969. Em 1966, participa do júri da $1^{\text {a }}$ Bienal Nacional da Bahia. Em 1964, é preso por 50 dias e, em 1969, é aposentado compulsoriamente e afastado da universidade.

Em 1973, escreve o capítulo Arte e Tecnologia, para o livro Arte Brasileira Hoje, de Ferreira Gullar (1930), no qual Schenberg aproxima as duas áreas de seu interesse. Nessa década, escreve artigos sobre concretismo e neoconcretismo para a revista Arte Hoje. Em 1979, retorna à universidade, devido à lei de anistia. Em 1983, ganha o prêmio de Ciência e Tecnologia do Conselho Nacional de Pesquisas (CNPq) e, em 1987, recebe título de professor emérito pelo Centro Brasileiro de Pesquisas Físicas. 
Anexo B - Currículo Artístico de Mario Schenberg ${ }^{454}$

Tive um interesse permanente pela arte desde os oito anos de idade, quando visitei pela primeira vez a Europa com meus pais.

Iniciei os meus estudos sobre História da Arte em 1938, durante a minha segunda viagem a Europa. Nessa ocasião visitei numerosos museus catedrais e palácios na Itália, Suíça, França, Bélgica e Portugal. Em 1939 conheci em Paris os pintores Emiliano di Cavalcanti e Noemi Mourão. Nessa época iniciei também meus estudos sobre História do Cinema em Paris, onde conheci Plínio Sussekind Rocha e Paulo Emílio de Salles Gomes.

De volta ao Brasil em 1939, passei a freqüentar a residência de Oswald de Andrade, onde conheci o pintor José Oswald de Andrade e escultora e desenhista Teresa d'Amico. No fim de 1940 viajei para os Estados Unidos, onde trabalhei dois anos como Fellow da John Simon Guggenheim Memorial Foundation em Astrofísica. Nesse período pude aprofundar os meus conhecimentos sobre Artes Plásticas, Fotografia e Cinema visitando numerosos Museus de Arte em New York, Washington, Baltimore, Philadelphia e Chicago. Nos Estados Unidos iniciei meus estudos sobre a Arte do Extremo Oriente e sua Filosofia.

Nos Estados Unidos fiz trabalhos artísticos de fotografia, tendo feito uma exposição no Observatório de Yerkes (Universidade de Chicago). O trabalho em fotografia me permitiu uma compreensão mais profunda dos problemas da arte. Nos Estados Unidos entrei em contato com alguns artistas importantes com Zadkine e Tamayo, aos quais fui apresentado por Teresa d'Amico em New York.

De volta ao Brasil em 1942, fui apresentado por Bruno Giorgi a Alfredo Volpi, de quem me tornei amigo íntimo até hoje. Minha atividade de crítico de arte foi iniciada com a organização da primeira exposição individual de Volpi, para a qual escrevi o texto do catálogo, além de ter tirado as fotografias das telas.

Bruno Giorgi e Alfredo Volpi me apresentaram aos artistas do Grupo Santa Helena, com os quais estabeleci sólidas relações de amizade. Conheci também José Pancetti, do qual me tornei também amigo íntimo até o fim de sua vida.

\footnotetext{
${ }^{454}$ Centro Mario Schenberg de Documentação da Pesquisa em Arte - ECA?USP.
} 
Depois da volta dos Estados Unidos, freqüentei também o atelier de Lasar Segal, que já conhecia desde 1940. Freqüentei também o atelier de Flávio de Carvalho. Posteriormente tornei-me amigo de Cândido Portinari, cujos murais já conhecera nos Estados Unidos. Convivi muito com Portinari em Paris depois de 1948. Nessa época conheci também pessoalmente numerosos artistas europeus, entre os quais Picasso, Chagall e Gutuso, além dos brasileiros Mario Gruber, Carlos Scilar e Antônio Bandeira.

No período entre 1942 e 1948 escrevi sobre Volpi, Pancetti, Bruno Giorgi e Figueira, sem exercer sistematicamente a crítica de arte. Comecei, porém a me relacionar com a crítica de arte paulistana, tornando-me amigo de Lourival Gomes Machado, Sérgio Milliet, Maria Eugenia Franco, Ciro Mendes, além de Paulo Mendes de Almeida, Osório César e Jorge Amado que já conhecera anteriormente.

De 1948 até 1953 permaneci na Europa. Nesses anos ampliei muito o meu conhecimento da arte européia, nas viagens que fiz pelos países da Europa Ocidental, Central e Oriental. As viagens pela Inglaterra, Holanda, Dinamarca, Alemanha, Aústria, Polônia, Checoslovaquia, Suíça, França e Itália, me permitiram conhecer melhor várias épocas da Arte Européia, assim como da Arte Africana e Asiática, pelas obras dessas regiões expostas em museus da Europa.

De 1953 a 1958 fiquei afastado de atividades artísticas e críticas limitando-me a visitar as Bienais de São Paulo e a fazer algumas leituras sobre as movimentos da arte contemporânea. A partir de 1958, aprofundei os meus contactos com o movimento artístico participando de debates sobre a pintura de Volpi em São Paulo e no Rio de Janeiro, estimulado por Mario Pedrosa, Waldemar Cordeiro e Theon Spanudis. Intensifiquei então os meus contatos com os artistas concretistas de São Paulo e com os neo-concretistas do Rio de Janeiro que conheci na exposição de Volpi do Museu de Arte Moderna de lá.

Em 1961 fui encarregado por Mário Pedrosa de organizar a Retrospectiva de Volpi na Bienal e de escrever o texto correspondente, por me considerar como a pessoa com melhor conhecimento da obra de Volpi e de haver reconhecido primeiro a sua estatura artística excepcional. A partir dessa Retrospectiva Volpi passou a ser considerado como uma das personalidades máximas da Arte Brasileira.

Participei das Bienais de 1965, 1967 e 1969 como representante dos artistas no Júri Nacional de Seleção. Participei do Júri da 1ª Bienal Nacional da Bahia em 1966 e dos júris de vários Salões em São Paulo e Minas Gerais, assim como do Júri do $1^{\circ}$ Salão 
da Bússola no Rio de Janeiro, em 1969. Desde então, participei apenas de alguns júris de Salões de cidades paulistanas até 1974.

Nas décadas de sessenta e setenta escrevi numerosas apresentações de artistas renomados como Volpi, Mario Gruber, Mira Schendel, Waldemar Cordeiro, Rubem Gerchman, Antonio Dias, Roberto Magalhães, Hélio Oiticica, José Roberto Aguilar, Arnaldo Ferrari, Cláudio Tozzi, Frederico de Morais, Roberto Mariconi, Antônio Marx, Teresa d'Amico, Ivald Granato, Érika Steinberger, Jenner Augusto, Sônia Castro, Waldomiro de Deus, Moby, Niobe Xandó, Ricardo Augusto Pinho, Marlene Trindade, Vera Ilse, Anésia Pacheco e Chaves, Lourdes Cedran, Kinoshita, Aluizio Siqueira, Sheila Brannigan, Bruno Giorgi, Zoravia Bettiol, Umberto Espíndola, Saverio Castellano, Sérgio Lima, João Rossi, Ely Bueno, Montez Magno, João Parisi, Alice Carracedo, Neusa d'Arcancny, Maurício Nogueira Lima e de numerosos artistas jovens.

Escrevi sobre arte em jornais de São Paulo e do Rio de Janeiro e também em revistas de arte. Sou autor do estudo "Arte e Tecnologia", incluído na obra Arte Brasileira Hoje de Ferreira Gullar, publicado em 1973 pela Editora Paz e Terra. Publiquei o estudo "Bruno Giorgi e o Paganismo" na Revista Acadêmica, nº 66, 1945, dedicado a Bruno Giorgi. Publiquei recentemente um estudo sobre os movimentos concreto e neo-concreto na Revista Arte Hoje, nº 02, 1977. Escrevi também vários estudos como textos de catálogos de exposições coletivas.

Sou membro da Associação Internacional dos Críticos de Arte e da Associação Brasileira dos Críticos de Arte. Sou membro da Academia Brasileira de Ciências e da Academia de Ciências do Estado de São Paulo e professor aposentado da USP.

Mário Schenberg 
Anexo C - Autobiografia de Mario Schenberg ${ }^{455}$

Nasci a 2 de Julho de 1914, em Recife. Em 1931 iniciei o curso na Escola de Engenharia de Pernambuco. Em 1933 transferi-me para a Escola Politécnica de São Paulo, recebendo o diploma de engenheiro eletricista em 1935.

Em 1936 concluí o curso de bacharel em matemática na Faculdade de Filosofia, Ciências e Letras da Universidade de São Paulo, na primeira turma da Faculdade. Desde 1936 trabalho na USP. Inicialmente fui preparador na cadeira de Física Geral e Experimental na Escola Politécnica e, no ano seguinte, fui nomeado assistente de Física Teórica na FFCLL. Em 1944 fiz concurso na USP para a cadeira mecânica Celeste e Superior do Departamento de Física da FFCL, que depois tornou-se o Instituto de Física.

Realizei muitas viagens ao exterior. Em 1939 parti para a Europa, tendo trabalhado no Instituto de Física da Universidade de Roma com o professor Enrico Fermi. A seguir, transferi-me para Zurique onde trabalhei com o prof. Pauli. Com a aproximação da guerra, parti para parti para Paris onde fiquei trabalhando com o prof. Frederic Joliot Curie.

Em 1940, já de volta ao Brasil, ganhei uma bolsa da Fundação Guggenheim e trabalhei com o Prof. G. Gamow em Washington, realizando investigações em Astrofísica. Depois, fui membro do Institute for Advanced Studies de Princeton. Trabalhei ainda no Observatório Astronômico de Yerkes com o prof. Schanndrasekar. Voltei em 1944 para o Brasil, para prestar concurso na USP. Permaneci no Brasil até 1948 quando parti para a Europa, ficando 5 anos em Bruxelas, trabalhando em raios cósmicos e mecânica estatística; trabalhei também com o prof. Prigogine, com o prof. Cosnyns e colaborei com o grupo de Prof. Occhiialini.

Em 1953, tornei-me diretor do Departamento de Física da USP. Permaneci neste cargo até 1961. Durante este período, criei o Laboratório de Estado Sólido e instalei o primeiro computador, criando assim os cursos de computação da USP. Ao longo de todos esses anos publiquei mais de uma centena de trabalhos em Física Teórica, Física Experimental, Astrofísica, Mecânica Estatística, Mecânica Estatística, Mecânica Quântica, Relatividade, Teoria Quântica do Campo, fundamentos de Física, além de escrever muitos trabalhos em Matemática.

${ }^{455}$ Centro Mario Schenberg de Documentação da Pesquisa em Arte - ECA?USP. 
Participei ativamente da discussão dos problemas político-econômicos do Brasil. Inicie em São Paulo a campanha O Petróleo é Nosso; lutei pela defesa de nossos recursos de minérios nucleares, e estou envolvido nos debates sobre as centrais nucleares.

Nos últimos anos tenho me dedicado com muito interesse a trabalhos de História da Ciência. Estive sempre interessado pelos problemas da Educação. Participei da realização da Bienal de São Paulo e escrevi muitos ensaios sobre arte.

Mario Schenberg

Década de 1980 
Anexo D - Histórico do Centro Mario Schenberg de documentação da pesquisa em Arte - ECA/USP

\section{DOAÇÃO DO ARQUIVO SCHENBERG ${ }^{456}$}

O Arquivo Schenberg foi doado à Associação dos Pesquisadores em Artes - ABPA, durante a homenagem feita ao professor Mario Schenberg pelos pesquisadores desta Associação, por ocasião do I Congresso Nacional da ABPA, no Conselho Universitário da Universidade de São Paulo, em 1988.

O acervo é constituído de hemeroteca, dos livros de arte do próprio Schenberg, dos catálogos de exposições que assinou, de periódicos e, principalmente, de cerca de quatrocentos e quinze originais das críticas de arte do professor (sendo que grande parte corresponde ao período de 1963 e 1987, com 32 títulos referentes a movimentos e grupos artísticos), cujo valor histórico deve ser preservado.

Contém ainda manuscritos, cartas, recortes de periódicos, fotografias e discos. Com a organização desse material, torna-se possível aquilatar o pensamento estético de Mario Schenberg. Com o desdobramento dessa proposta vêm sendo realizadas várias pesquisas e atividades no Centro Mario Schenberg de Documentação da Pesquisa em Artes ECA/USP.

${ }^{456}$ Centro Mario Schenberg de Documentação da Pesquisa em Artes - ECA/USP 


\section{Ana Clara Guerrini Schenberg}

Graduação em Ciências Biológicas pela Universidade de São Paulo (1967) e doutorado em Sciences Naturelles - Université de Paris-Sud (1971). Atualmente é Professor Senior da Universidade de São Paulo - Yeast (Chichester) e - Brazilian Journal of Microbiology. Tem experiência na área de Genética Molecular e de Microrganismos, atuando principalmente nos seguintes temas: Saccharomyces cerevisiae, Cupriavidus metallidurans, Cupriavidus necator, biotecnologia, expressão heteróloga, reparo e mutagênese. ${ }^{457}$

\section{Fábio Magalhães}

Fábio Luiz Pereira de Magalhães (São Paulo SP 1942). Pintor e desenhista. Cursa história da arte no Masp, com Wolfgang Pfeiffer, e estuda com Nelson Nóbrega na Escola de Arte da Faap. Em 1964, viaja para Paris, França, onde frequenta o Instituto de Arte e Arqueologia e entra em contato com os integrantes do movimento internacional Phases. Nesse mesmo ano, é selecionado pelo MAC/SP para representar o Brasil, ao lado de outros artistas, no Salon Comparaisons de Paris. Ao longo de sua carreira, exerce várias atividades dentre elas: diretor da Pinacoteca do Estado de São Paulo; membro da Comissão de Arte do MAM/SP (1978 a 1980); conservador chefe do Masp (1990) e curador das exposições Coleção Pirelli/Masp. Entre as exposições de que participa, destacam-se: Salão do Trabalho, São Paulo, 1962/1963 (Menção Honrosa, 1963); Salão Paulista de Arte Moderna, São Paulo, 1963/1964 (Menção Honrosa, 1963); Exposição do Jovem Desenho Nacional, Porto Alegre e São Paulo, 1963/1965 (Menção Honrosa, 1963); Propostas 65, na Faap, São Paulo, 1965; Bienal ao Ano 2000, no MAC/USP, São Paulo, 1975; Salão Nacional de Artes Plásticas, Rio de Janeiro, 1981. ${ }^{458}$

\section{Caciporé Torres}

\footnotetext{
${ }^{457}$ Disponível em: http://lattes.cnpq.br/0353705043616506 Acesso em: 05/05/2018.

${ }^{458}$ FÁBIO Magalhães. In: ENCICLOPÉDIA Itaú Cultural de Arte e Cultura Brasileiras. São Paulo: Itaú Cultural, 2018. Disponível em: <http://enciclopedia.itaucultural.org.br/pessoa12321/fabiomagalhaes>. Acesso em: 03 de Abr. 2018. Verbete da Enciclopédia. ISBN: 978-85-7979-060-7.
} 
Caciporé de Sá Continho da Lamare Torres (Araçatuba SP 1935). Escultor, desenhista e professor. Viaja para a Europa através de bolsa de estudos que recebe na $1^{\text {a }}$ Bienal Internacional de São Paulo, de 1951, e durante dois anos frequenta os ateliês de escultura de Marino Marini (1901 - 1980) e Alexander Calder (1898 - 1976). Retorna ao Brasil em 1953, participa de exposições, e posteriormente, regressa à Europa. Em 1954, estuda história da arte na Sorbonne, Paris, e trabalha em ateliê durante 4 anos, período em que desenvolve obra de caráter abstracionista. Passa a construir formas maciças orgânicas e geométricas, utilizando peças metálicas de aparência industrial, como o aço, bronze e ferro. Muitas dessas esculturas são feitas em grandes dimensões e integram museus e espaços públicos de diversas cidades, como as obras na Praça da Sé, metrô Santa Cecília, e painel escultórico em Miami, Estados Unidos. Entre 1961 e 1971, leciona escultura na Fundação Armando Álvares Penteado - Faap e, a partir de 1971, na Faculdade de Arquitetura e Urbanismo da Universidade Presbiteriana Mackenzie, ambas em São Paulo. Em 1970, é eleito presidente da Associação Internacional de Artes Plásticas/Unesco, e, em 1980 e 1982, melhor escultor brasileiro pela Associação Paulista de Críticos de Artes - APCA. É agraciado com a Comenda Mário de Andrade pelo Governo do Estado de São Paulo, na gestão de Paulo Egydio Martins. ${ }^{459}$

\section{Maria Bonomi}

Maria Anna Olga Luiza Bonomi (Meina, Itália 1935). Cenógrafa e figurinista. Realiza cenários e figurinos de destaque nos anos 1960, principalmente ao lado do diretor Antunes Filho, com quem realiza trabalhos em que cenografia e encenação interagem num amálgama artístico de primeira grandeza.

Opta pela nacionalidade brasileira em 1953, formando-se em desenho na Universidade de Columbia, Nova York, em 1956, tornando-se artista plástica.

Seu primeiro trabalho como cenógrafa é em As Feiticeiras de Salém, de Arthur Miller, em 1960, para o Pequeno Teatro de Comédia. No ano seguinte, para essa mesma companhia, faz Sem Entrada e Sem Mais Nada, de Roberto Freire, ambos espetáculos de Antunes Filho, seu futuro marido.

\footnotetext{
${ }^{459}$ CACIPORÉ Torres. In: ENCICLOPÉDIA Itaú Cultural de Arte e Cultura Brasileiras. São Paulo: Itaú Cultural, 2018. Disponível em: 〈http://enciclopedia.itaucultural.org.br/pessoa21475/cacipore-torres〉. Acesso em: 04 de Mai. 2018. Verbete da Enciclopédia. ISBN: 978-85-7979-060-7
} 
Em 1962, no Teatro Brasileiro de Comédia (TBC), está em Yerma, de Federico García Lorca, outra encenação de Antunes, levando o Prêmio Associação Paulista de Críticos de Teatro (APCT), de melhor figurino. Logo a seguir, faz A Morte do Caixeiro Viajante, de Arthur Miller, uma direção de Flávio Rangel para a casa. Para o Teatro da Esquina, empreendimento de Antunes e Ademar Guerra, Maria faz dois trabalhos de grande relevo: A Megera Domada, de William Shakespeare, em 1965, premiada com o Saci, Molière e APCT de melhor cenógrafa, e A Cozinha, de Arnold Wesker, 1968, em que ganha melhor cenografia pelo Prêmio Governador do Estado, ambos conduzidos por Antunes.

Para o mesmo diretor, em 1967, cenografa Black-Out, de Frederick Knott, reproduzindo um autêntico apartamento nova-iorquino para ambientar a ação.

Para o mesmo encenador cria, em 1970, os figurinos de Peer Gynt, de Henrik Ibsen, sendo novamente premiada. Em 1971, cria o apartamento do publicitário de Corpo a Corpo, de Oduvaldo Vianna Filho, sua última colaboração com Antunes Filho, de quem se separa em 1972. Com Ademar Guerra, no Paraná, faz dois trabalhos bemsucedidos: A Colônia Cecília, de Renata Palottini, em 1984, e Noite na Taverna, de Álvares de Azevedo, 1989, duas superproduções envolvendo elencos numerosos. ${ }^{460}$

\section{José Roberto Aguilar}

José Roberto Aguilar (São Paulo, São Paulo, 1941). Pintor, videomaker, performer, escultor, escritor, músico e curador. Autodidata, integra o movimento performáticoliterário Kaos, em 1956, com Jorge Mautner (1941) e José Agripino de Paula (19372007). Em 1963, expõe pinturas na $7^{\text {a }}$ Bienal Internacional de São Paulo. Considerado um dos pioneiros da nova figuração no Brasil, participa da mostra Opinião 65, no Museu de Arte Moderna do Rio de Janeiro (MAM/RJ), em 1965. Nessa época, passa a pintar com spray e pistola de ar comprimido. Vive em Londres, entre 1969 e 1972, e em Nova York, entre 1974 e 1975, época em que inicia suas experimentações com vídeo. Volta a morar em São Paulo em 1976. No ano seguinte, participa da 14 Bienal Internacional de São Paulo com a instalação Circo Antropofágico Ambulante Cósmico e Latino-

${ }^{460}$ MARIA Bonomi. In: ENCICLOPÉDIA Itaú Cultural de Arte e Cultura Brasileiras. São Paulo: Itaú Cultural, 2018. Disponível em: <http://enciclopedia.itaucultural.org.br/pessoa8447/maria-bonomi>. Acesso em: 03 de Mai. 2018. Verbete da Enciclopédia. ISBN: 978-85-7979-060-7 
Americano Apresenta Esta Noite: A Transformação Permanente do Tabu em Totem, em que expõe 12 monitores de TV no palco do Teatro Ruth Escobar. Em 1981, cria o grupo musical Banda Performática e lança o livro A Divina Comédia Brasileira. Torna-se discípulo do líder espiritual indiano Rajneesh, em 1983, e começa a assinar suas telas como Aguilar Vigyan. Em 1989, realiza a performance Tomada da Bastilha, com a participação de 300 artistas, assistida por cerca de 10 mil pessoas em São Paulo. Nos anos 1990, faz pinturas em telas gigantes e esculturas em vidro e cerâmica. De 1995 a 2002, é diretor do espaço cultural Casa das Rosas, em São Paulo. Em 2003, Aguilar é nomeado representante do Ministério da Cultura na capital paulista. ${ }^{461}$

\section{Sílvio Salinas}

Engenheiro Elétrico e Bacharel em Física pela Universidade de São Paulo (1966). Doutor em Física pela Carnegie-Mellon University, Pittsburgh, USA (1973). Professor Titular aposentado do Instituto de Física da Universidade de São Paulo. Publicou artigos científicos e livros na área de física estatística, principalmente sobre propriedades de modelos estatísticos para transições de fase em sistemas de interesse físico. Orientou diversas teses e dissertações. ${ }^{462}$

${ }^{461}$ JOSÉ Roberto Aguilar. In: ENCICLOPÉDIA Itaú Cultural de Arte e Cultura Brasileiras. São Paulo: Itaú Cultural, 2018. Disponível em: <http://enciclopedia.itaucultural.org.br/pessoa4002/jose-robertoaguilar>. Acesso em: 10 de Mai. 2018. Verbete da Enciclopédia. ISBN: 978-85-7979-060-7 ${ }^{462}$ Fonte: http://lattes.cnpq.br/3856979779391522 Acesso em: 03/05/2018. 
Senhor presidente da república: artistas, críticos, intelectuais brasileiros e participantes desta grande iniciativa cultural, hoje de âmbito internacional que é a Bienal de São Paulo, congratulam-se com a presença de V. Ex. ${ }^{a}$ aqui neste recinto e pede vênia para fazer o seguinte apelo: Sustar, por sua apropriada intervenção, a efetivação da prisão preventiva que acaba de ser decretada pela Auditoria Militar de São Paulo contra o professor Mario Schenberg, depois de ter o STM [Superior Tribunal Militar] ter considerado insubsistente por falta de fundamento jurídico a acusação que contra ele foi levantada, bem como contra seus colegas universitários, professores Fernando Henrique Cardoso, João da Cruz Costa e Florestan Fernandes.

O professor Mário Schenberg, além de físico de renome mundial, tem parte ativa na vida artística do Brasil como um dos seus críticos mais eminentes, tendo participação no júri de seleção desta Bienal.

Os abaixo assinados cumprimentam respeitosamente o presidente da República (seguem as assinaturas de todos os artistas brasileiros na Bienal).

${ }^{463}$ Castelo inaugura a Bienal dizendo que a arte serve à paz. Jornal do Brasil (Estado da Guanabara), 05/09/1965. 
Anexo G - Carta de Mário Pedrosa para Mario Schenberg, 02/02/1961.

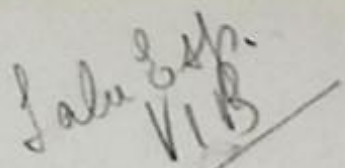

$\operatorname{2ran}-10211-$

São Paulo,2 de fevereiro de 1961

Ilmo. Senhor

Prof. Marto Schemberg

Rua São Vicente de Paula,501

apital

Meu velho amtgo,

Após nossa sonversa telefonica de ontem fiquei contente om saber que a rotrospectiva do Volpi será confiada a v. en lugar do Spanudis que viajará brevernento.

Agora fico aguardando seu comparecinento para traçarmos o plano dofinitivo da exposigão.

Seu,

Wario Pedrosa

D1retor Geral 
Anexo H - Ultima Hora, 2a edição, São Paulo, 25/03/1964 (capa).

JOHNSON EMOCIONADO: RANGIR HBRU AS PORTHS DH LUA - PRGINA 5

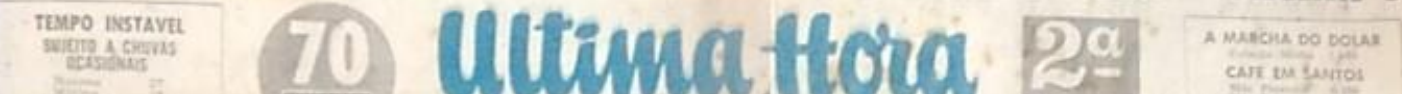

Cin $=2$

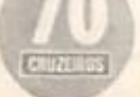

Eणाफल0

LIDER DO PTB AMEACADO DE MORTE

NA CAMARA POR UM "BIGORRILHO"

Peri : Estão Tentando Transformar a Justiça Militar Num Instrumento de Perseguiçãa Politica STM UNANIME VOTA PELA
LIBERDADE DE SCHEMBERG

Jogou-se no

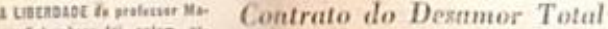
Poco Com os 2 Filhinhos

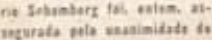

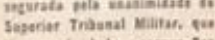

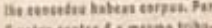

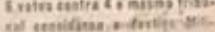

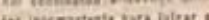

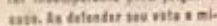

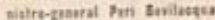

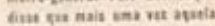
Cirte catan medo chisubs

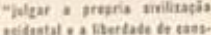

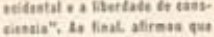

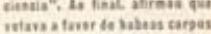

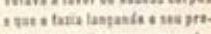

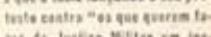
in do datipa Miltar in ine teas". O pretrast Ments

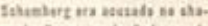
cato Presses is calerse of

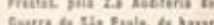
verato

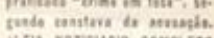
Leis senteusia comprets is stoovda neina
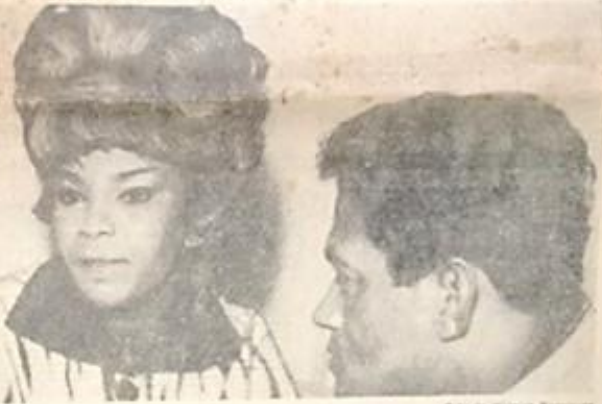

Ficou Louca Mãe da Menina Raptala

\section{(1)}

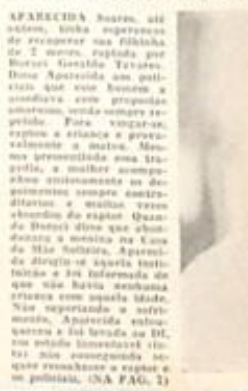

SANTOS: 300 MILHÕES POR "MANE" SEM ELSA

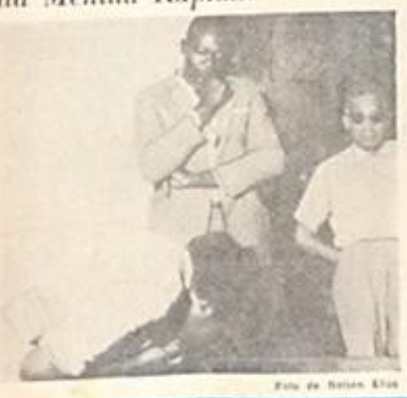

CARrincru pode voler et $300 \mathrm{mit}$ Hiess 5 o Santes esta dingorts a po. ga-les as tatalegs mas, vezinds see prenidente, Ahis Jarge Caurn.

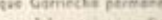
.

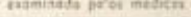
delmante, que tin ce

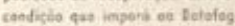
O s. Aht Jinge Coun ave ainds que Camacha duar tha saoma

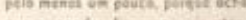

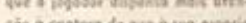

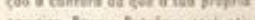
me nenosias more Gerrieshy ficey

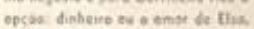
(LEA NOTICLARO NA PAG, 11).

PAGINA 4 - ADOLFO LUTZ ABSOLVE LAQUÊ: NÃO FAZ MAL 
Anexo I - Autorização para saída do país. Justiça Militar, 02/08/1965.

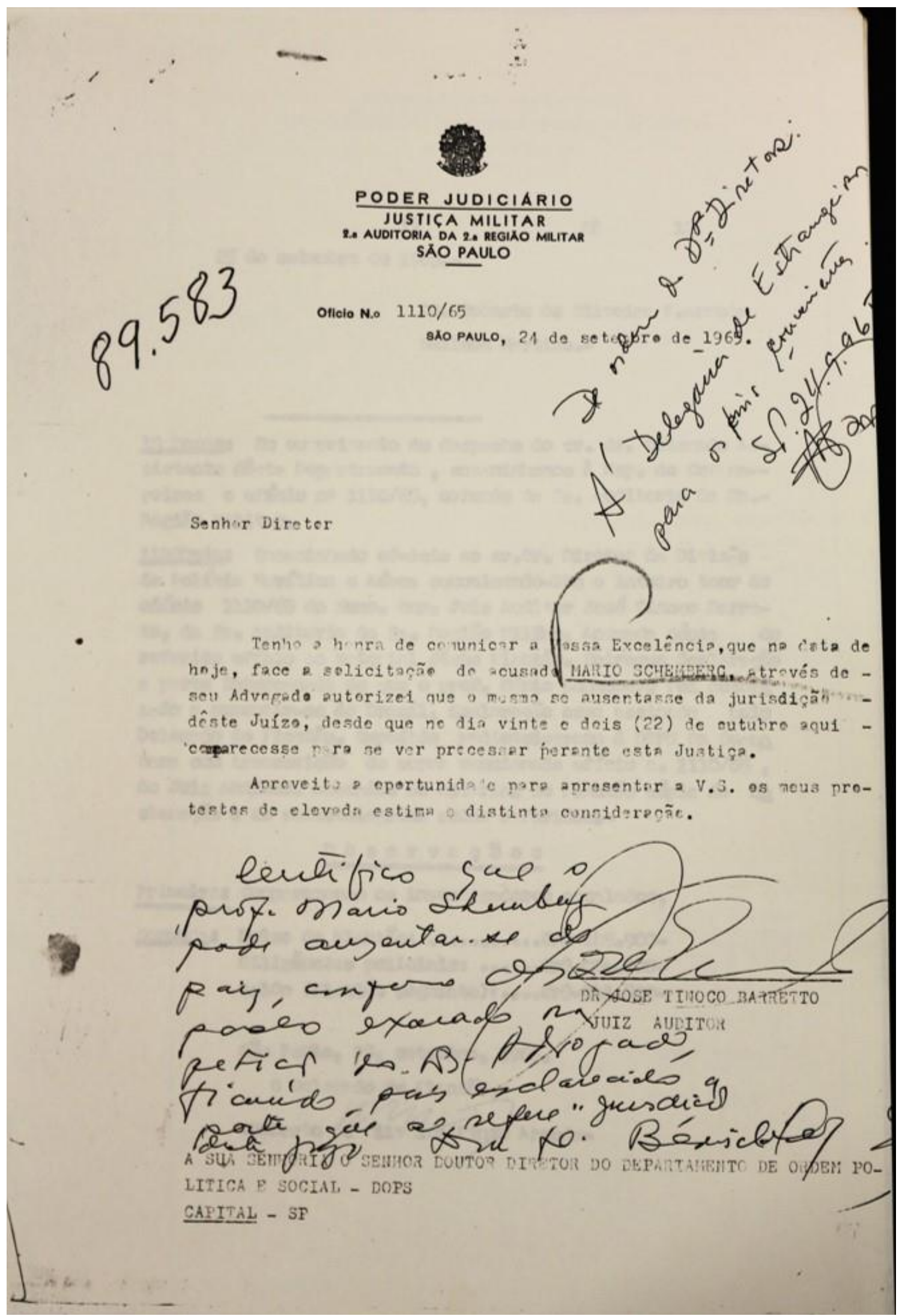


Anexo J - Yoshiya Takaoka, Retrato de Mario Schenberg, 1962

Figura 61 - Yoshiya Takaoka, Retrato de Mario Schenberg, 1962, óleo sobre tela, 46 x 38 cm. Coleção Particular. Reprodução Fotográfica Rubens Chiri/Itaú Cultural. O artista participou das Bienais de 1951 e de 1959.

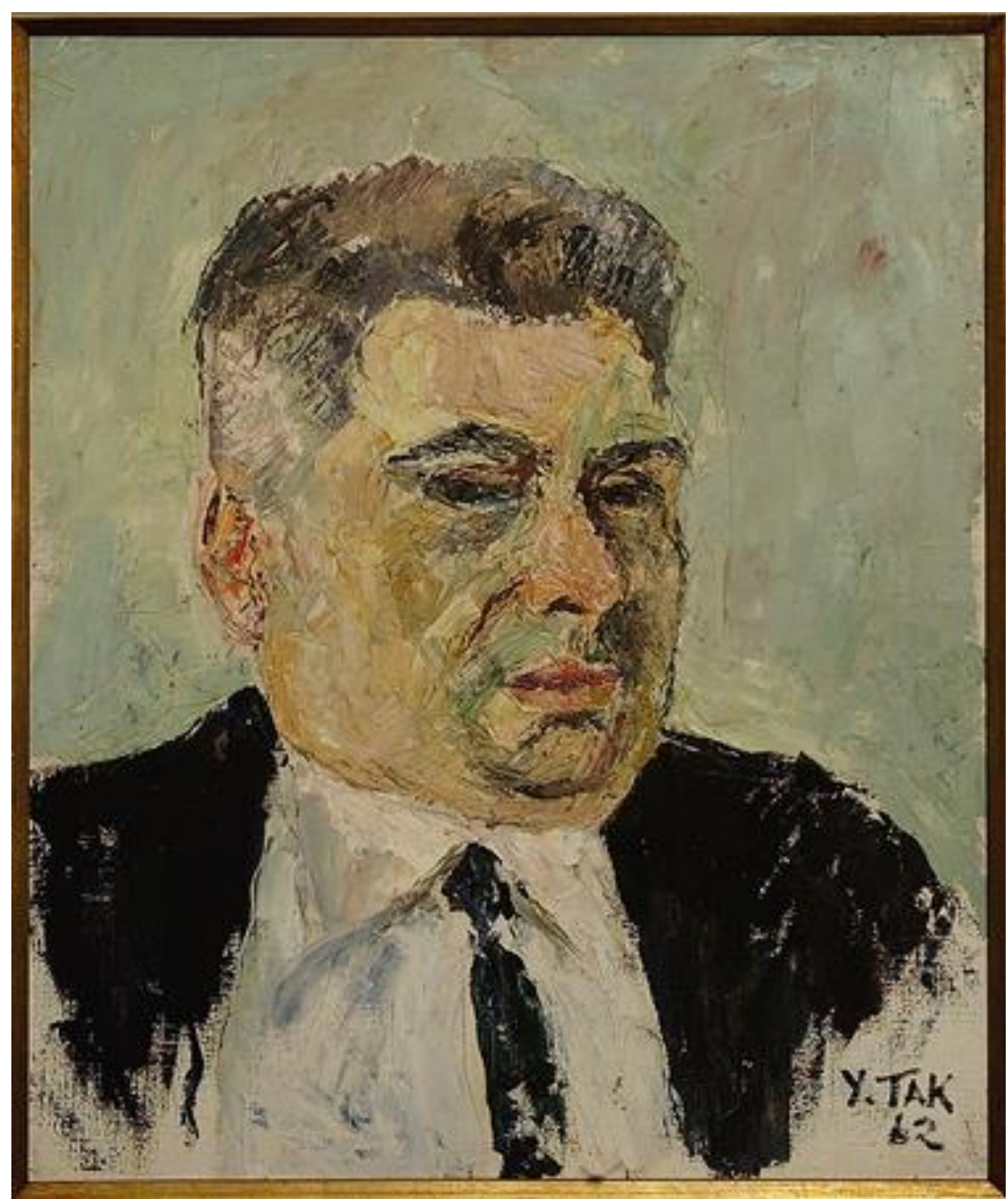

Fonte: RETRATO de Mario Schenberg. In: ENCICLOPÉDIA Itaú Cultural de Arte e Cultura Brasileiras. São Paulo: Itaú Cultural, 2018. Disponível em:

<http://enciclopedia.itaucultural.org.br/obra43762/retrato-de-mario-schenberg>. Acesso em: 05 de Jun. 2018. 
Anexo K - Capa do catálogo da primeira individual de Alfredo Volpi

Figura 62 - Capa do catálogo da primeira exposição individual de Alfredo Volpi. Nele, constam o texto introdutório escrito por Schenberg e fotos de algumas telas, bem como a lista de obras.

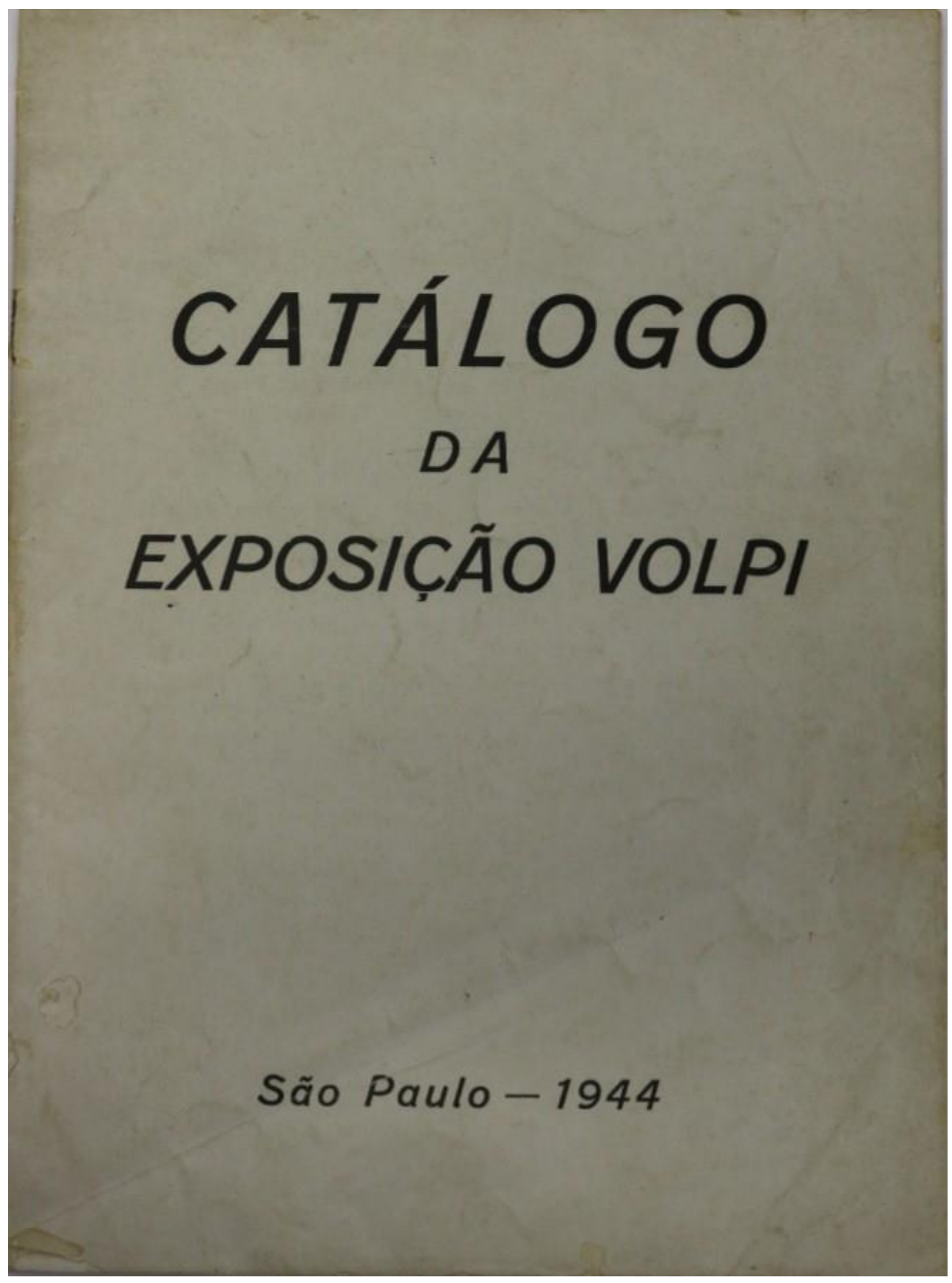

Fonte: Centro Mario Schenberg de Documentação da Pesquisa em Arte ECA USP. 
Anexo L - VI Bienal - reprodução de obra de Alfredo Volpi.

Figura 63 - VI Bienal de São Paulo. Reproduções de quadros de Alfredo Volpi. Autoria desconhecida. A tela foi identificada, trata-se de Fachada com Bandeiras, 1959, Têmpera sobre tela, 116 x $72 \mathrm{~cm}$. Acervo do Museu de Arte de São Paulo - MASP, doação de Ernest Wolf.

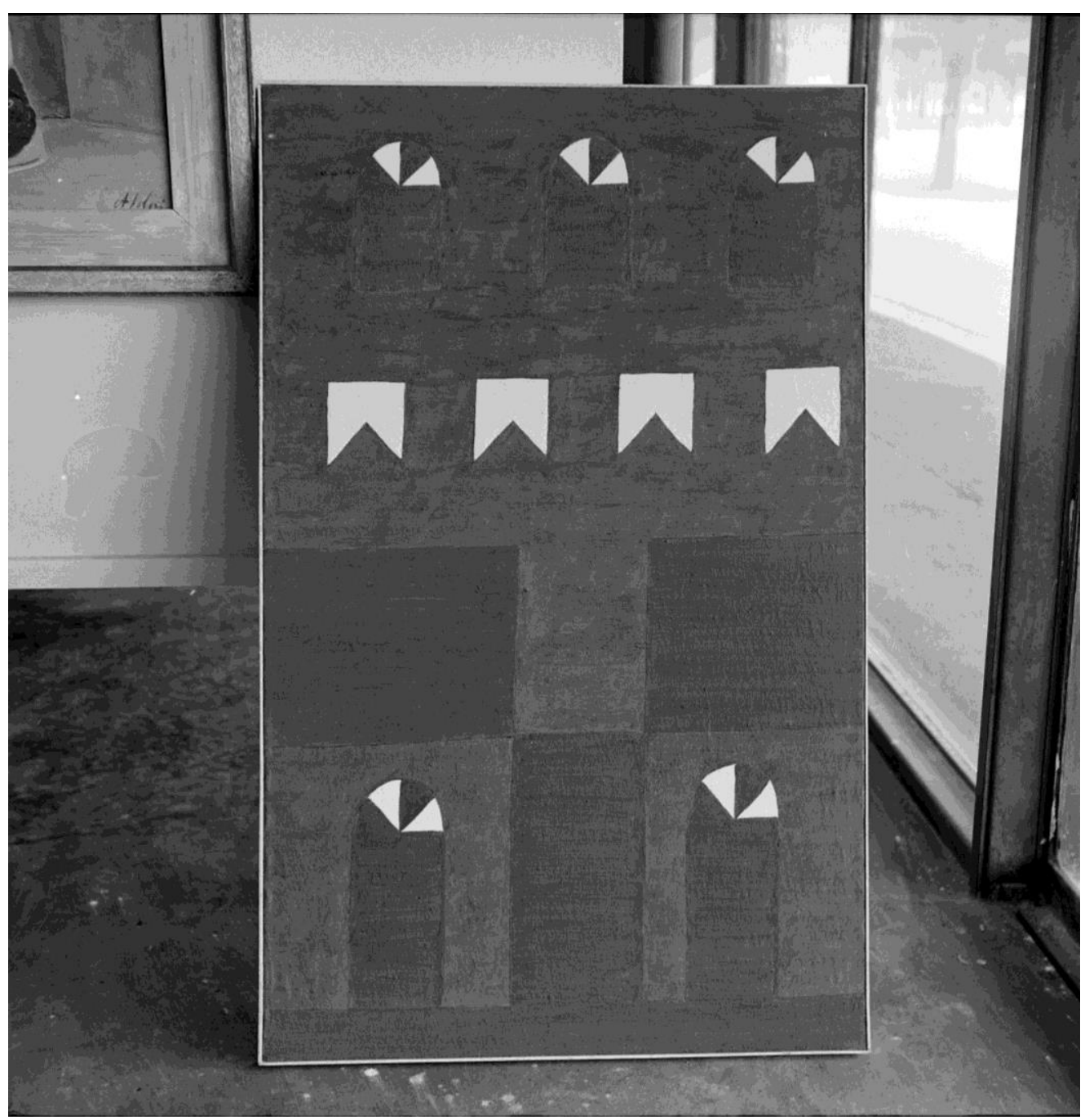

Fonte: Arquivo Histórico Wanda Svevo/Fundação Bienal. 
Anexo M - VI Bienal - reprodução de obra de Alfredo Volpi.

Figura 64 - VI Bienal de São Paulo. Reproduções de quadros de Alfredo Volpi. Autoria desconhecida.

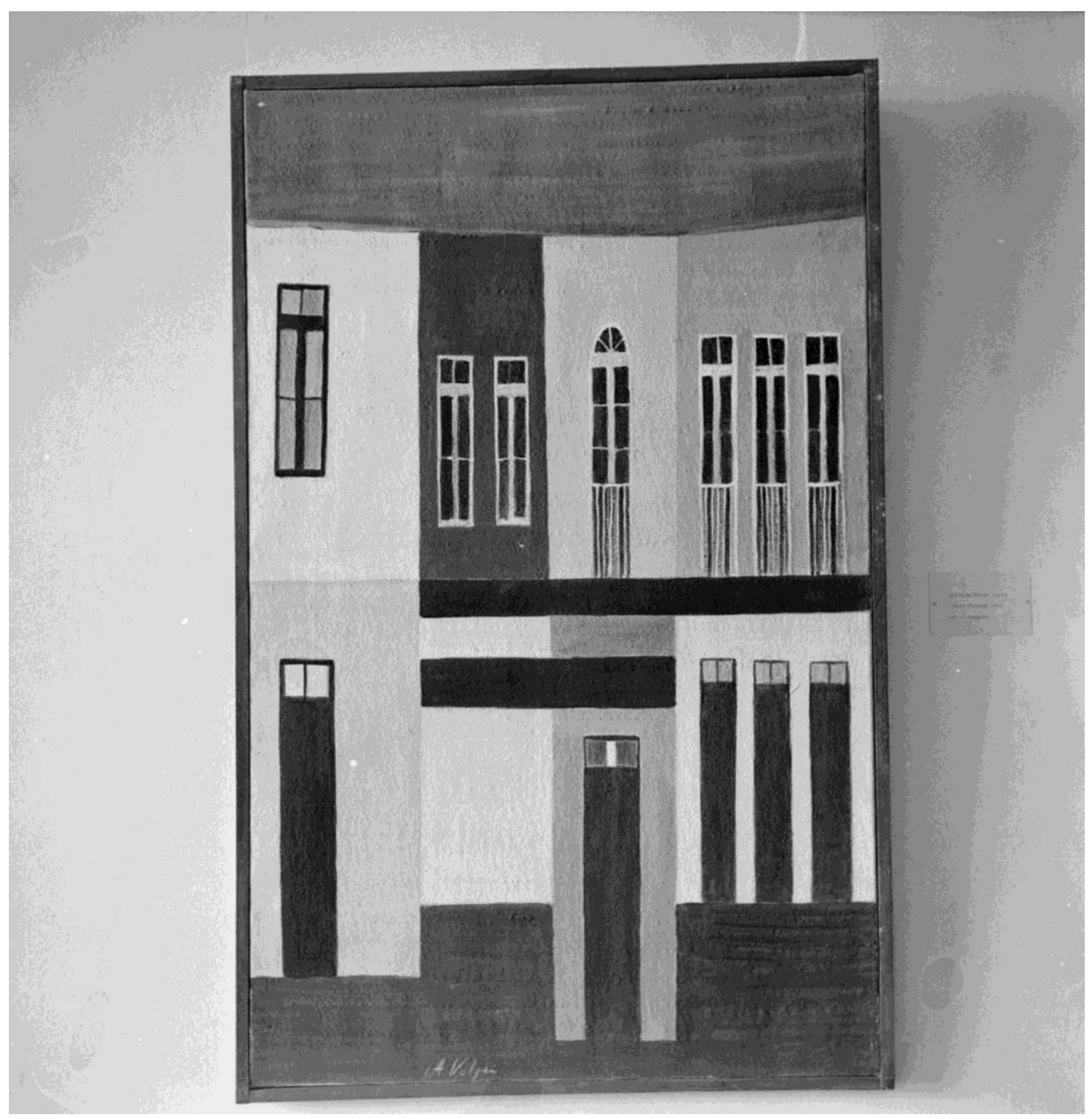

Fonte: Arquivo Histórico Wanda Svevo/Fundação Bienal. 
Anexo N - Planta da sala especial de Alfredo Volpi.

Figura 65 - Planta da sala especial dedicada a Alfredo Volpi. Nesse espaço, foram colocadas 95 as obras do artista.

SALAS RETROSPECTIVAS:

ALFREDO VOLPI

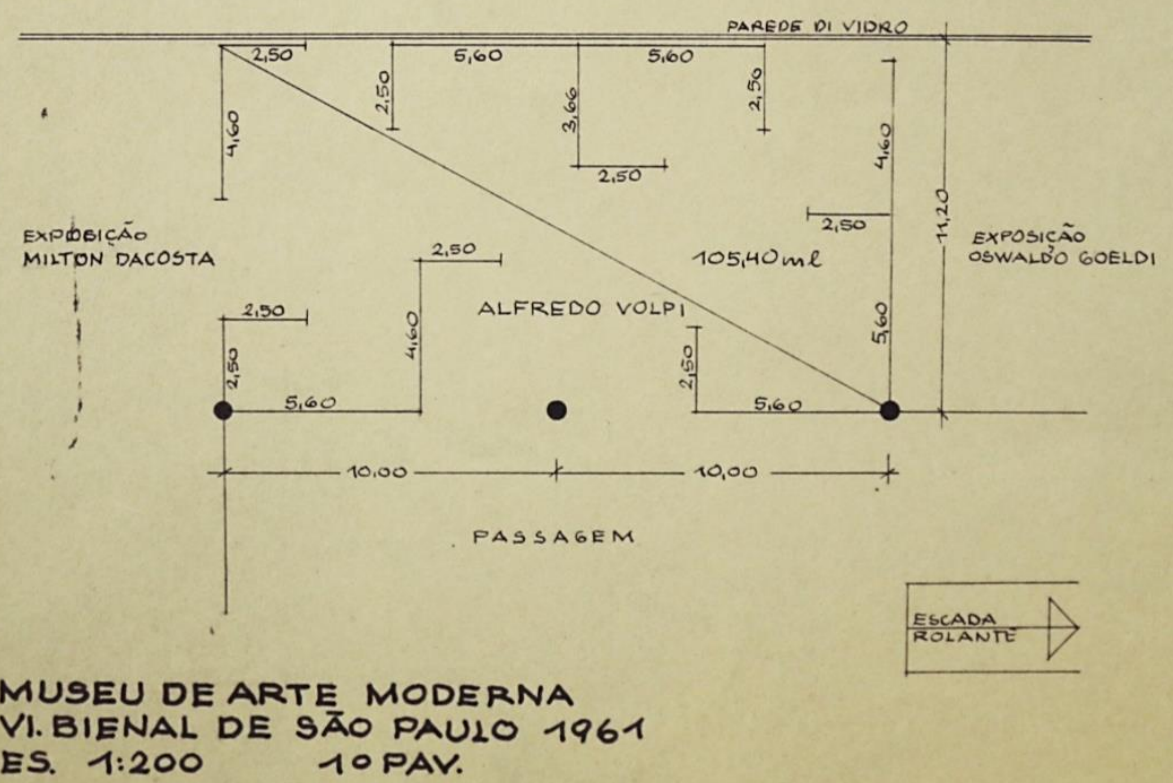

Fonte: Arquivo Histórico Wanda Svevo/Fundação Bienal. 
Anexo O - Alfredo Volpi, Theon Spanudis e Mario Schenberg, 18/06/1056.

Figura 66 - O pintor Afredo Volpi, na platéia, em conferência sobre sua obra. Museu de Arte Moderna, em São Paulo, em junho de 1956.

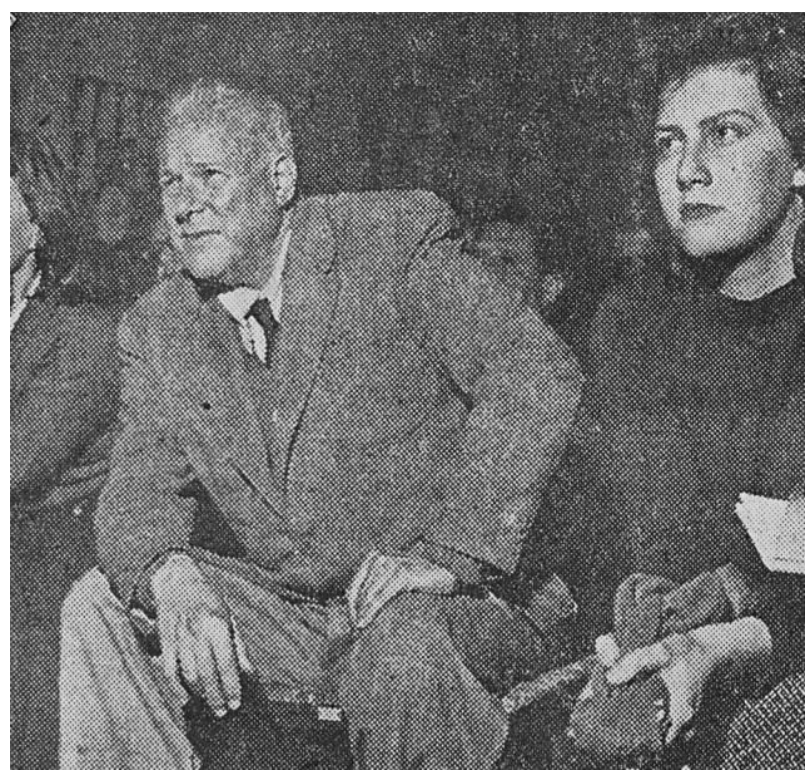

Fonte: Folha da Noite, São Paulo (capital) 18/06/1956.

Figura 67 e 68 - Theon Spanoudis e Mario Schenberg em conferência sobre a obra de Alfredo Volpi. Museu de Arte Moderna, em São Paulo, em junho de 1956.
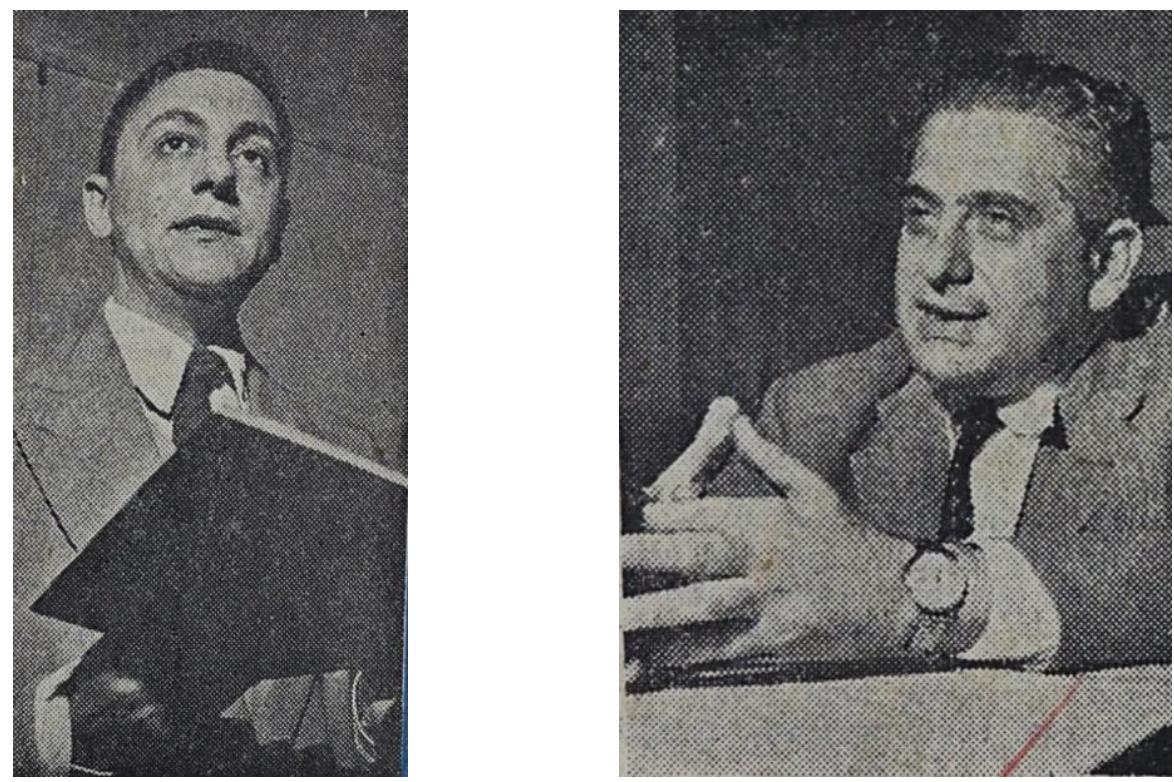

Fonte: Folha da Noite, São Paulo (capital) 18/06/1956. 
Anexo P - X Bienal de São Paulo, vista externa. II Bienal de Ciência e Humanismo

Figura 69 - X Bienal de São Paulo, vista externa. Estruturas temporárias, em forma de oca, construídas para abrigar os eventos da II Bienal de Ciência e Humanismo. Autoria desconhecida.

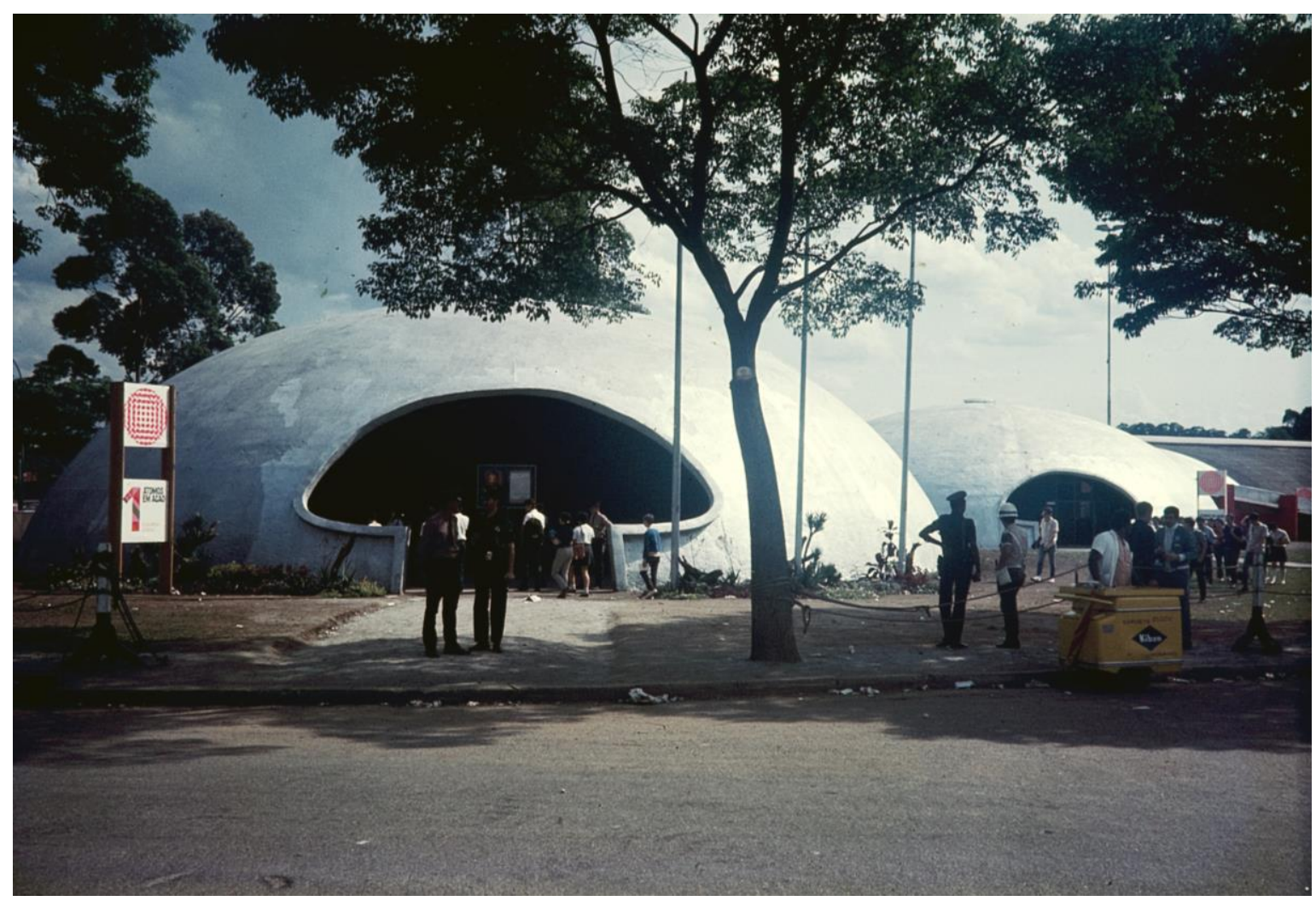

Fonte: Arquivo Histórico Wanda Svevo/Fundação Bienal. 
A cronologia apresentada a seguir foi elaborada com base em dados obtidos no livro Schenberg: Crítica e Criação, de Alecsandra Matias de Oliveira (São Paulo: EDUSP, 2011). Foram utilizados, ainda, os seguintes catálogos: Acervo MAC USP Homenagem a Francisco Matarazzo Sobrinho, (São Paulo: MAC USP, 2006) e Operários na Paulista: MAC USP e artistas artesãos (São Paulo: MAC, 2002), ambos com organização de Elza Ajzenberg, bem como Volpi: pequenos formatos (São Paulo: Museu de Arte Moderna de São Paulo, 2016), com a organização de Aracy Amaral.

Aos dados já existentes, foram acrescentados aqueles encontrados nesta pesquisa, principalmente com relação à década de 1960 .

Década de 1910

1914 - Nasce Mario Schenberg em 2 de julho, em Recife - PE.

$1911-1930$

- Alfredo Volpi trabalha como pintor-decorador de paredes em edifícios e residências paulistanas.

$1916-1918$

- Por conta da I Guerra Mundial, a Bienal de Veneza, criada em 1895, teve suas edições do período interrompidas.

1917

- Exposição de Pintura Moderna de Anita Malfatti.

Década de 1920

1922

- Schenberg faz sua primeira viagem à Europa, onde inicia seu interesse por arte, principalmente por arquitetura.

- Semana de Arte Moderna, no teatro Municipal de São Paulo. 
1924

- Manifesto Pau-Brasil.

1925

- Alfredo Volpi participa de sua primeira exposição coletiva. Vende uma pintura.

1926

- Schenberg assiste a comícios e manifestações políticas, começando a se interessar por marxismo e torcendo pela Coluna Prestes.

1928

- Manifesto Antropófago.

1929

- Schenberg termina o curso secundário em Recife e dirige-se ao Rio de Janeiro.

Década de 1930

1930

- Na escola politécnica do Rio de Janeiro, Mario Schenberg faz um curso de vestibular, retornando a Recife, no final do ano, para ingressar na Escola de Engenharia.

- Washington Luíz é deposto e Getúlio Vargas assume o governo provisório (Brasil).

1930/1935

- Repressão radical do operariado (São Paulo/ Brasil).

$1930 / 1937$

- Codificação da Legislação Trabalhista (Brasil).

1931

- Mesmo ilegal, o Partido Comunista expande-se a partir de 1931 para declinar em 193740 (Brasil).

- Surge o Partido Socialista (Brasil). 
1933

- Schenberg transfere-se para a Escola Politécnica de São Paulo, motivado por uma publicação onde se cogitava a criação de uma Faculdade de Ciências.

$1933-1935$

- Expansão progressiva da indústria brasileira, principalmente no período intermediário proporcionado pela Segunda Guerra Mundial, entre 1939 e 1945 (Brasil).

1934

- Schenberg publica, como estudante, seu primeiro trabalho científico, intitulado "Os Princípios da Mecânica".

- Fundação da Universidade de São Paulo (São Paulo/SP).

- Promulgada a Nova Constituição Brasileira (Brasil).

- Vargas é eleito presidente da República (Brasil).

1935

- Schenberg forma-se engenheiro eletricista pela Escola Politécnica da Universidade de São Paulo.

- Grupo Santa Helena (São Paulo/SP). Integrantes: Aldo Bonadei, Alfredo Volpi, Alfredo Rullo Rizzotti, Clóvis Graciano, Fulvio Pennacchi, Humberto Rosa, Manoel Martins e Mário Zanini.

- Extinção do Partido Socialista Brasileiro (Brasil).

1936

- Schenberg obtém o Bacharelado em Matemática pela recém-criada (1934) Faculdade de Filosofia, Ciências e Letras da Universidade de São Paulo. Publica seu primeiro trabalho como físico teórico na revista italiana II Nuovo Cimento, sobre eletrodinâmica quântica.

1937

- Criação do Sindicato dos Artistas Plásticos de São Paulo - SINAP/AIAP.

- Abolição dos Partidos (Brasil). 
- Estado Novo, sob o comando de Getúlio Vargas (Brasil).

1938

- Schenberg viaja para a Europa, onde passa a trabalhar com Enrico Fermi, em Roma. Aprofunda-se seu interesse por arte, principalmente em Paris e na Bélgica.

1939

- Schenberg conhece, em Paris, o pintor Di Cavalcanti. De volta ao Brasil, passa a frequentar a casa de Oswald de Andrade, onde conhece a artista Teresa D"Amico.

\section{Década de 1940}

1940

- Como fellow da Fundação Guggenheim, Schenberg viaja aos Estados Unidos, onde faz seus primeiros trabalhos de astrofísica, com George Gamow, sobre o processo Urca.

- Schenberg faz trabalhos artísticos de fotografias e os expõe no Observatório de Yerkes, da Universidade de Chicago.

- III Salão da Família Artística Paulista (São Paulo/SP).

- Alfredo Volpi tem trabalho de temática religiosa premiado por Mário de Andrade, Bruno Giorgi e Sérgio Milliet no concurso realizado para ressaltar esforços do SPHAN (Serviço do Patrimônio Histórico e Artístico Nacional), com relação a monumentos restaurados.

1941

- Schenberg publica com Chandrasekhar um importante trabalho sobre evolução estelar, criando o critério Schenberg-Chadrasekhar para estrelas da sequência principal.

- Schenberg inicia estudos sobre a filosofia oriental e sobre a relação da filosofia com a arte. 
- Schenberg retorna ao Brasil e ao Departamento de Física da USP. Começa, de forma não sistemática, a escrever sobre artistas brasileiros e a se relacionar com a crítica de arte paulistana.

- Conferência de Mário de Andrade: O movimento modernista, na Casa do Estudante (São Paulo/SP).

- Antigetulistas querem a entrada do Brasil na Segunda Guerra Mundial (1939 - 1945)

(Brasil).

- Brasil declara guerra ao Eixo (Brasil).

- Após o início das hostilidades durante a Segunda Guerra Mundial, as atividades da Bienal de Veneza foram interrompidas. A última edição da Exposição de Arte ocorreu em 1942 para retomar apenas em 1948.

- Schenberg conhece o pintor Alfredo Volpi, do qual adquire uma marinha.

1944

- Schenberg apresenta tese sobre "Os Princípios da Mecânica", tornando-se professor catedrático da cadeira de Mecânica Racional, Celeste e Superior da USP.

- Schenberg organiza, escreve o texto e fotografa as obras do catálogo da primeira exposição individual de Volpi, na Galeria Itá, em São Paulo. Todas as obras são vendidas.

1945

- Criação da seção de Arte e o Museu na Biblioteca Municipal de São Paulo (São Paulo/SP).

- Morte de Mário de Andrade (São Paulo/SP).

- Exposição de Artistas Plásticos na Galeria Itá, em homenagem a Mário de Andrade (São Paulo/SP).

- Recuo do Getulismo (Brasil).

- Data das eleições é antecipada, Eurico Gaspar Dutra é eleito presidente (Brasil).

$1945-1949$

- Alfredo Volpi participa de Salões, coletivas e individuais em São Paulo, Rio de Janeiro, Chile e Argentina. 
- Ciccillo decide formar uma coleção de arte contemporânea internacional. Em viagem à Europa, conta com o auxílio de Alberto Magnelli e de sua mulher, Yolanda Penteado, para a seleção das obras.

- Em novembro, Nelson Rockefeller, presidente do MoMA, em visita ao Brasil, reúnese com um grupo de intelectuais que tencionam criar um museu de arte moderna em São Paulo. Nessa ocasião, Rockefeller doa 18 obras para o futuro museu.

- Schenberg elege-se deputado estadual em São Paulo, pelo Partido Comunista. Depois de dois meses de atuação na Assembleia Legislativa tem, juntamente com todos os parlamentares eleitos pelo PC, seu mandato cassado.

\section{$1946 / 1947$}

- Margherita Sarfatti e Livio Gaetani compram obras junto a galerias e artistas italianos. O marchand Enrico Salvador encarrega-se da aquisição do Autorretrato de Modigliani de 1919.

1947

- Ciccillo e Yolanda apresentam parte da coleção em sua casa da rua Estados Unidos, com muitas reações desfavoráveis a obras como o Autorretrato de Amadeo Modigliani (1919) e Mulher Feliz de Francis Picabia (s/d). As obras de sua coleção estavam distribuídas entre a residência da rua Estados Unidos e a Metalúrgica Matarazzo. Por motivos de saúde, Ciccillo submete-se a tratamento em Davos (Suíça). Simultaneamente, estabelece contatos com Nierendorf, a quem pensa convidar para dirigir o futuro museu. Porém, Nierendorf falece antes da efetivação do museu.

- Trabalho de Schenberg em favor da elaboração do Projeto de Lei que veio a ser o Artigo 123 da Constituição Paulista de 1947, marcando o início das negociações para a criação da FAPESP, o que se concretizaria apenas no início da década de 1960.

- Inauguração do Museu de Arte de São Paulo (MASP).

1948

- Schenberg é preso no início do ano sob acusação de subversão à ordem pública. Liberado meses depois, retorna à Europa, onde passa a lecionar na Universidade Livre de Bruxelas, na Bélgica, até seu retorno ao Brasil.

- Ciccillo visita a XXIV Bienal de Veneza.

- Criação do Museu de Arte Moderna de São Paulo (MAM). 
- Criação da Associação Internacional de Críticos de Arte - AICA, na França, como organização não governamental ligada à UNESCO.

1949

- Inauguração do Museu de Arte Moderna de São Paulo, com a mostra Do Figurativismo ao Abstracionismo. Exposição que aprofunda a discussão sobre a oposição entre arte figurativa e abstrata. Organizada por Léon Degand, a mostra reúne 95 obras. Participam nomes como Arp, Calder, Waldemar Cordeiro, Robert Delaunay, Kandinsky, Picabia e Vasarely.

- Criação da Associação Brasileira de Críticos de Arte - ABCA, em São Paulo, como seção brasileira da AICA.

\section{Década de 1950}

1950

- Intensificam-se os intercâmbios internacionais. Ciccillo torna-se Comissário do Brasil na XXV Bienal de Veneza; o MAM SP faz a seleção da representação brasileira nesse evento.

1951

- Criada por Ciccillo, a I Bienal Internacional de São Paulo é inaugurada em um pavilhão provisório no Trianon, na Avenida Paulista. A premiação de Max Bill faz da arte concreta o ponto alto da mostra. A partir das premiações das Bienais, diversas obras vão sendo incorporadas ao acervo do MAM SP. Ciccillo também adquire muitas outras obras participantes das Bienais que integrarão sua coleção particular.

- Alfredo Volpi participa da I Bienal de São Paulo. Theon Spanudis adquire sua primeira tela do artista.

1952

- Ciccillo adquire os gessos originais de Desenvolvimento de uma Garrafa no Espaço (1912) e Formas Únicas da Continuidade no Espaço (1913), de Umberto Boccioni. Compra, também, a escultura Cavalo (1951) de marino Marini.

- É Comissário do Brasil na XXVI Bienal de Veneza.

- Grupo Ruptura. 
1953

- De volta ao Brasil, Schenberg é eleito para o cargo de Diretor do Departamento de Física da USP, sendo reeleito até 1961.

- $1^{\text {a }}$ Exposição Nacional de Arte Abstrata.

- Integrando as comemorações do IV Centenário de São Paulo, a II Bienal torna-se sucesso de público e crítica. Alfredo Volpi divide com Di Cavalcanti o Prêmio Nacional de Pintura. Volpi participaria, ainda, da terceira e da quarta edições da mostra. Na quinta, integra o júri de premiação da mostra.

1954

- Alfredo Volpi participa da XXVII Bienal de Veneza. Ano de viagem à Bahia com Theon Spanudis, da qual resulta produção de pinturas com fachadas e religiosas.

- Grupo Frente.

1955

- A III Bienal de São Paulo marca a maturidade dos artistas concretos como Waldemar Cordeiro, Lygia Clark, Luiz Sacilotto e Maurício Nogueira Lima. Dedicam-se salas especiais para Cândido Portinari, Lasar Segall, Diego Rivera, Orozco, Siqueiros, Rufino Tamoyo e Ferdnand Léger.

- I Documenta de Kassel.

1956

- Por motivos de saúde, Ciccillo cede a Sérgio Milliet o Comissariado da Delegação do Brasil na XXVIII Bienal de Veneza.

- Em 25 de maio, é aberta, no Museu de Arte Moderna de São Paulo, uma exposição individual contendo obras das obras da fase mais recente de Alfredo Volpi. Em 11 de junho, realiza-se um debate sobre a trajetória do artista, que foi aberto por Theon Spanoudis, e contou com a presença de José Geraldo Vieira (que presidiu os trabalhos), Samson Flexor, Carlos Pinto Alves, Mario Schenberg e Waldemar Cordeiro.

- $1^{\text {a }}$ Exposição Nacional de Arte Concreta, no MASP, em São Paulo.

- Manifesto da Poesia Concreta. 
- Ciccillo faz testamento, dando a Yolanda o usufruto do apartamento da Avenida Paulista e da coleção de arte.

- A IV Bienal é a primeira edição realizada no Pavilhão das Indústrias (atualmente Pavilhão Ciccillo Matarazzo - Parque Ibirapuera).

- Exposição Nacional de Arte Concreta no MAM RJ.

1958

- Schenberg reinicia uma atividade mais permanente de crítica de arte, principalmente através de contatos com Volpi e Mário Pedrosa.

- O MAM SP, órgão responsável pela organização das bienais, transfere-se para o atual Pavilhão Ciccillo Matarazzo. Há problemas para distinguir o que pertencia ao MAM, o que era de fato doação de Ciccillo e de Yolanda Penteado, e o que não havia sido doado e estava somente depositado no Museu.

1959

- O método de gestão do MAM e a vinculação das finanças ao seu presidente, Ciccillo, resultam em uma reforma dos estatutos. Já está em curso a separação das bienais do MAM.

- A V Bienal tem sala especial sobre Van Gogh, destaque para Karel Appel e Manabu Mabe.

- Schenberg recebe 9 votos de artistas na eleição para o Júri de Seleção da bienal desse ano, superando, por exemplo, Bruno Giorgi, Mário Pedrosa, Sérgio Milliet e mesmo Cândido Portinari.

- Manifesto Neoconcreto.

Década de 1960

1961

- Ciccillo e Yolanda penteado separam-se.

- A VI Bienal tem direção artística de Mário Pedrosa. O evento ganha lugar no contexto internacional, articulando-se com a Documenta de Kassel e a Bienal de Veneza.

- Schenberg organiza a Retrospectiva de Volpi para a Bienal desse ano. 
1962

- Schenberg elege-se deputado estadual, com a maior votação do PTB de São Paulo, tendo o registro do diploma impedido pelo Tribunal Eleitoral, sob a alegação de pertencer ao Partido Comunista.

$1962-1963$

- Surge a Fundação Bienal, uma instituição privada sem fins lucrativos.

- Ciccillo relaciona as obras da coleção que estão no apartamento da Avenida Paulista, discriminando as de Yolanda e as dele, que serão incluídas na doação que, posteriormente, fará à Universidade de São Paulo. Mas que, em um primeiro momento, ficarão sob custódia de Yolanda.

- Meses depois, já está assinada a escritura de doação da coleção Francisco Matarazzo Sobrinho e Yolanda Penteado à USP. A doação é realizada em duas etapas: lote de 429 obras em 1962, e 19 obras, em 1963, prevendo o usufruto por parte dos doadores, que resolveram antecipar a doação em 1973.

1962-1969

- Alfredo Volpi integra importantes mostras em São Paulo e no Rio de Janeiro, e ainda no México, Argentina, Alemanha, além de duas edições da Bienal de Veneza. Na XXXII edição da mostra de Veneza, recebe o Primeiro Prêmio.

1963

- A Universidade de São Paulo, em 8 de abril, recebe o lote de 1236 obras vindas do MAM SP.

- A partir das três coleções iniciais de Francisco Matarazzo Sobrinho, Yolanda Penteado e MAM SP, a Universidade cria o Museu de Arte Contemporânea.

- Francisco Matarazzo Sobrinho recebe o título de doutor Honoris Causa. D. Yolanda penteado é agraciada com o Diploma de Benemerência.

- $1^{\circ}$ happening no Brasil, por Wesley Duke Lee.

1964

- Golpe Militar. 
- Schenberg foi preso logo após o Golpe, no começo do ano, sendo posto em liberdade após cerca de 50 dias. Teve sua prisão preventiva decretada em outubro, para a qual não se apresentou, permanecendo foragido.

- 13 de outubro: novo mandado de prisão preventiva é expedido contra Mario Schenberg.

- Fundação do Museu de Arqueologia da Universidade de São Paulo. As primeiras peças arqueológicas foram uma doação de Ciccillo, obtidas a partir de escavações realizadas na cidade de Herculano/Itália.

1965

- Schenberg participa da Bienal desse ano, bem como das de 1967 e 1969, como representante dos artistas no júri nacional de seleção.

- 24 de março: habeas corpus concedido a Mario Schenberg.

- Setembro: instauração de novos inquéritos.

- 27 de abril: na bienal, são conhecidos os nomes dos representantes dos artistas no júri de seleção.

- 6 de maio: Schenberg passa a integrar o júri.

- 19 de maio: Francisco Mattarazzo Sobrinho divulga a relação dos artistas escolhidos.

- $1^{\mathrm{o}}$ de setembro: expedição de novo mandado de prisão.

- 4 de setembro: inauguração da VIII Bienal, primeira edição organizada pela

Fundação Bienal.

- 22 de setembro: Schenberg decide se entregar.

- 24 de setembro: expedido por ordem judicial, Schenberg teve a ordem de prisão suspensa para participar de uma conferência sobre partículas elementares em Kioto, Japão. É absolvido nos processos a que respondia desde o ano anterior, retornando às suas atividades na Universidade de São Paulo. No dia seguinte, embarcou para o Japão. - Exposição Opinião 65, no MAM RJ.

- Exposição Propostas 65, na Fundação Armando Álvares Penteado (FAAP), em São Paulo.

1966

- Exposição Opinião 66, no MAM RJ.

- Exposição Propostas 66, na Biblioteca Municipal Mário de Andrade, em São Paulo.

- Início da atuação do Grupo Rex em São Paulo. 
1967

- Lembrada como a Bienal da arte pop, a IX edição conta com os destaques de Andy Warhol e Jasper Johnson. Paralelamente, ocorre o Simpósio Mundial de Integração Ciência-Humanismo.

- Schenberg participa da Bienal como representante dos artistas no júri nacional de seleção.

- No MAC USP organiza-se a primeira edição da Jovem Arte Contemporânea, seguida posteriormente pelas exposições Jovem Desenho Nacional e Jovem Gravura Nacional.

- Exposição Nova Objetividade Brasileira, no MAM RJ.

1968

- AI - 5, em 13 de dezembro.

- Surge a Tropicália.

- O MASP é transferido para a Avenida Paulista, em edifício projetado por Lina Bo Bardi.

1969

- Sob boicote contra a ditadura militar que se instalara no país desde 1964, a X Bienal Internacional de São Paulo tem como destaque uma instalação de Mira Schendel. Paralelamente, ocorre a II Bienal de Ciência e Humanismo.

- Schenberg participa da Bienal como representante dos artistas no júri nacional de seleção e organiza, ainda, a sala especial Novos Valores.

- Schenberg participa da Mesa Redonda Internacional de Críticos de Arte da AICA.

- Ato Complementar 75, em 21 de outubro.

- Em decorrência do AI-5 e do Ato complementar 75, Schenberg tem decretada sua aposentadoria compulsória, sendo afastado de todas as suas funções universitárias.

\section{Década de 1970}

1970

- Inaugurada a I Bienal Nacional, seguida por outras três edições, em 1972, 1974 e 1976. 
- A XI Bienal Internacional de São Paulo, comemorando 20 anos de criação, ainda sofre boicote nacional e internacional. Paralelamente, ocorre a III Bienal de Ciências e Humanismo.

- Schenberg participa da Mesa Redonda Internacional de Críticos de Arte da AICA.

1972

- II Bienal Nacional.

1973

- Schenberg publica, na obra Arte Brasileira hoje, um estudo sobre arte e tecnologia.

- No auge do boicote, a Bienal homenageia artistas recém falecidos: Tarsila do Amaral, Waldemar Cordeiro, entre outros.

1974

- III Bienal Nacional.

1976

- Publicada a biografia de Francisco Matarazzo Sobrinho: O franciscano Ciccillo, de Fernando Azevedo de Almeida.

- Publicada a autobiografia de Yolanda Penteado: Tudo em cor de rosa.

- IV Bienal Nacional.

1977

- Em 16 de abril, Ciccillo falece em seu apartamento em São Paulo.

- O MAC USP, sob curadoria de Walter Zanini, realiza a Exposição - Homenagem a Francisco Matarazzo Sobrinho (1989 - 1977).

1978

- O espólio de Yolanda Penteado, cerca de 30 peças, é transferido ao MAC USP.

- I Bienal Latino-Americana, que substituiu as bienais nacionais. Apesar de ser projetada para ser sazonal, teve apenas uma edição.

1979

- Com a Lei da Anistia, Schenberg reintegra-se na Universidade de São Paulo. 
Década de 1980

1980

- Aperto, na Bienal de Veneza: dedicada à arte emergente.

1981

- Na XVI Bienal de São Paulo, surge a figura de um curador geral.

- Retomada da pintura.

1983

- Schenberg ministra o curso de Evolução dos Conceitos de Física, no Instituto de Física da USP.

- Recebe o Prêmio de Ciência e Tecnologia do Conselho Nacional de Pesquisas.

1984

- $1^{\mathrm{a}}$ Bienal de Havana.

- Em comemoração dos 70 anos de Schenberg, realiza-se, no Instituto de Física da USP, um simpósio em sua homenagem.

- É publicado o livro Mario Schenberg: Entre-Vistas organizado por José Goldfarb.

1985

- É publicado o livro Diálogos com Mario Schenberg sob coordenação de Lourdes Cendran.

- XVIII Bienal de São Paulo: “A Grande Tela”.

1986

- Schenberg recebe o título de cidadão Paulistano.

1987

- Numa homenagem realizada no Instituto de Física da USP, Schenberg recebe o título de Professor Emérito do Centro Brasileiro de Pesquisas Físicas.

- XIX Bienal de São Paulo: abertura de instituições culturais e galerias. 
1988

- É publicado o livro Pensando a Arte, reunindo diversos textos críticos de Mario Schenberg.

- Falece Alfredo Volpi em São Paulo, a 28 de maio, aos 92 anos de idade.

1989

- XX Bienal de São Paulo: trabalhos amadurecidos dos jovens artistas da Geração 80.

Década de 1990

1990

- Publicado o livro Pensando a Física, de Mario Schenberg.

- Em 10 de novembro, falece o Professor Mario Schenberg, em São Paulo.

1994

- José Luis Goldfarb publica Voar também é com os homens: o pensamento de Mario Schenberg.

1996

- É realizada, na Casa das Rosas, em São Paulo, a exposição O Mundo de Mario Schenberg.

- XXIII Bienal de São Paulo: novo recorde de representações.

1997

- $1^{\text {a }}$ Bienal do Mercosul.

1998

- Aracy Amaral organiza a mostra Sala Especial Volpi: Construção e reducionismo sob a luz dos trópicos, integrando o Núcleo Histórico da 24a Bienal de São Paulo.

1999

- XXIV Bienal de São Paulo: "Bienal da Antropofagia". 
Década de 2000

2005

- Bienal de Veneza: experiência com diversos curadores.

2006

- XXVII Bienal de São Paulo: extinção das representações nacionais.

- Abertura do Instituto Inhotim para o público, em Brumadinho, MG.

2008

- XXVIII Bienal de São Paulo: "Bienal do Vazio".

2010

- XXIX Bienal de São Paulo: projeto educativo permanente.

2012

- XXX Bienal de São Paulo: curadores internacionais começam a marcar presença na bienal. 